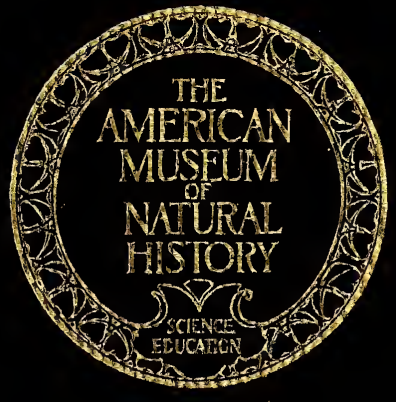




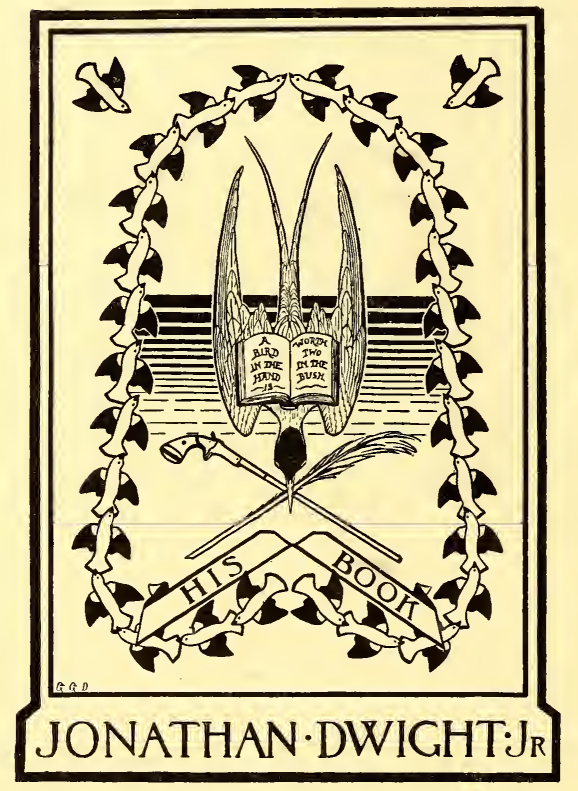




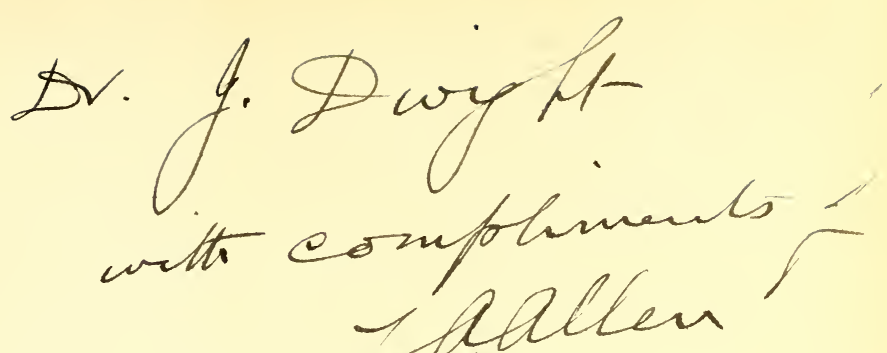






$$
2
$$




\section{AT'TOBIOGR.APHICAL NO'TES}

ANI)

\section{A BIBLIOGRAPHY}

OF THE

\section{SCIENTIIFIC PUBLICA'TIONS}

$\mathrm{OF}$

JOEL ASAPH ILLEN

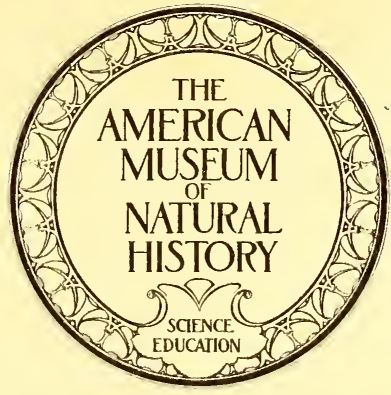

PUBLISHED BY THE MISEUM

NEW YORK

1916 



\section{Dedicated to \\ Henry Fairfield Osborn, \\ President of the American Museum of Natural History, and to the Memory of my revered Teacher, \\ Louis Agassiz.}





\section{FOREWORD.}

The life and writings of Joel Asaph Allen have exerted so great an influence on the progress of ornithology and mammalogy in America that all who have the interests of these branches of science at heart, both in this country and abroad, will welcome this biographical and bibliographical volume. It is issued as an expression of the appreciation of Doctor Allen's life work by the Trustees of The American Museum of Natural History and his devoted colleagues on its Scientific Staff. The biographical sketch was especially desired in connection with the Bibliography because it sets forth so clearly the broad groundwork of travel, of field observation and of field record which has established a model for all modern American work on the birds and the mammals. At this time we are sure that naturalists in all parts of the world will unite with Dr. Allen's colleagues in felicitating him on the great work which he has accomplished and in wishing him many more years of strength and activity.

November 9, 1916.

Henry Fairfield Osborn. 



\section{PREFACE.}

The present publication was prepared by request of Henry FaIRfield Osborn, President of the American Museum of Natural History, to whom the author is indebted for courtesies extending over many years of the most pleasant official relationship.

It is a pleasure, realized by few, to be able to supervise the publication of a list of one's own technical papers, extending over more than half a century, and the opportunity for it was duly welcomed.

The biographical sketch, preceding the list of papers, however, was written with great reluctance and with many misgivings, as being, in the author's opinion, inopportune in the present connection. If such notes are worthy of record, it seems more fitting that their publication should be posthumous. Their present appearance is due to solicitations difficult to disregard.

August 20, 1916.

$$
\text { J. A. Allen. }
$$





\section{CONTENTS.}

Title-page

Dedication

Foreword (by Henry Fairfield Osborn)

Preface

Contents

AutobIographical Notes

Early surroundings and training (1838-1858)

(1858-1862)

Special student under Louis Agassiz (1862-1871) . . . . . 8

With the Agassiz Expedition in Brazil (1865) . . . . . . 11

Collecting trip to the Middle West (1867) . . . . . 18

East Florida Expedition (1868-1869) . . . . . . 20

Assistant at Museum of Comparative Zoölogy (1871-1885) . $\quad 20$

Great Plains and Rocky Mountain Expedition (1871-1872) • . 20

Yellowstone Expedition (1873) . . . . . . . 27

Special collaborator, U. S. Geological and Geographical Survey of the Territories $(1876-1882)$. . . . . . . 32

Curator at American Museum of Natural History (since 1885) . $\quad$. 33

Affiliations with the American Ornithologists' Union and other scientific

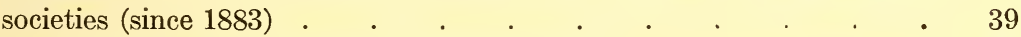

General considerations and home life (since 1874) . . . . . $\quad$. 42

Addenda . . . . . . . . . . . . . 43

Expeditions . . . . . . . . . . . . . . 434

Positions held . . . . . . . . . . . 44

Honors received (including memberships in home and foreign
Societies and Academies of Science) . . . . 45

BIBLIOGRAPHY . . . . . . . . . . . . . . . 49

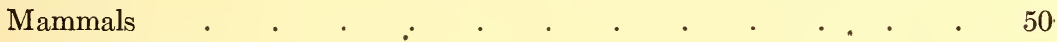

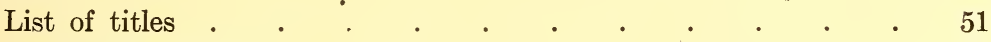

New higher groups $. \quad . \quad . \quad . \quad . \quad . \quad . \quad . \quad .83$

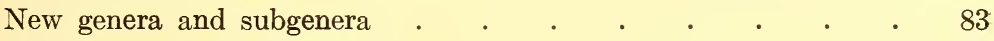

New species and subspecies .

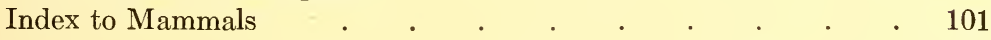
Birds

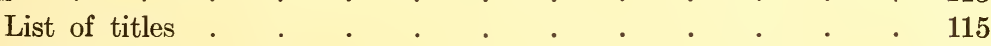

New genera . . . . . . . . . . . . . . 192

New species and subspecies . . . . . . . . . . 192

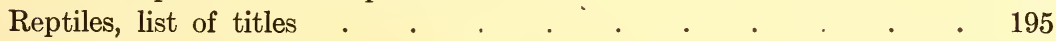

Zoögeography, list of titles . . . . . . . . . . . . 196

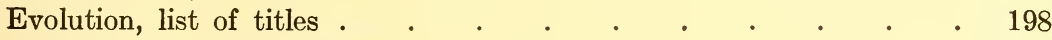

Nomenclature, list of titles . . . . . . . . . . . 201

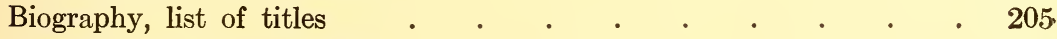

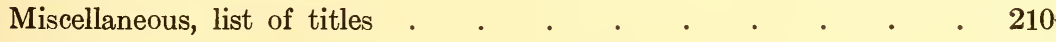

Editorial work . . . . . . . . . . . 213 

AUTOBIOGRAPHICAL NOTES. 



\section{AUTOBIOGRAPHICAL NOTES.}

\section{Early Surroundings and Training (1838-1858).}

I was born in Springfield, Massachusetts, July 19, 1838, the eldest son of Joel and Harriet (Trumbull) Allen, both of early New England stock. My father was a descendant, in the seventh generation, of Samuel Allen, who settled in Windsor, Connecticut, in 1640. The date of his birth is not positively known, nor has a definite record been found of when he emigrated from England. He is supposed to have come over with the Dorchester Company in 1630, in the ship 'Mary and John.' ${ }^{1}$ The Windsor land records show that he received a grant of land from the plantation at Windsor, Connecticut, January 27, 1640. He died at Windsor in 1648. The present public library building at Windsor marks the site of the Samuel Allen homestead. Joel Allen, my father, was born in Springfield, Massachusetts, December 11, 1810.

On the maternal side the descent is from John Trumbull, great-grandfather of Governor Jonathan Trumbull (said to have been the original "Brother Jonathan" and familiar friend of Washington), who was born in Newcastle-on-Tyne, England, and settled in Roxbury, Massachusetts, in 1639.

My immediate progenitors were farmers. My father, however, learned the carpenter's trade and was a house-builder in his earlier days, but later bought a farm on which he spent the greater part of his life. He was respected by his neighbors as a man of excellent judgment and sterling integrity, whose advice was often solicited in the affairs of the neighborhood. In politics he was a Free-soiler, and later a Republican. He died January 9,1886 , at the age of 75 years and one month, survived by my mother, three sons and a daughter. My mother died June 2, 1892, at the age of 80 years and six months. My mother taught school for several years before her marriage. She was a true helpmeet, practical, conscientious, and in every way lovable and inspiring. My father had little appreciation for my natural history tastes, but was kind and generous, offering to share his farm with me if I would remain with him on the old homestead. My mother, on the other hand, was much in sympathy with my yearnings, and often used her influence in my favor.

1 The first leaves of the Dorchester records are stated to be missing. 
Our family numbered five children, one girl and four boys, one of whom (a boy, Edwin) died in infancy. My sister, Harriet Emma, taught school for a number of years and later married a farmer. She died suddenly of pneumonia, contracted in attending a sick brother, April 2, 1900, in her 54th year. My two brothers, Edgar, a moulder by trade, and Irving, a farmer, are still (August, 1916), living, the latter at the old homestead in Springfield.

My early training was rigidly puritanical. My parents were both members of the Congregational church, and strict in their religious observances. Family prayers invariably followed breakfast, and also closed the routine of Sunday, all the religious requirements of the day being strictly observed.

My earliest recollections are naturally associated with the surroundings of my birthplace on the old farm, situated on a hill about a mile and a half east of the then thickly settled part of Springfield, known as the Watershops, where the United States Government has for more than a century carried on the manufacture of fire-arms. The family home was a large two-story square-roofed house, at that time innocent of paint and unshaded by trees. One of the pleasantest remembrances of my younger days is of helping my father plant the row of maples and elms which long since became the prominent feature of the road frontage of the farm, and in recovering and painting the house. We were not crowded by neighbors, the nearest residence on the west being half a mile away, and there was only one house within half a mile to the eastward. Subsequently others much nearer were built in. both directions, the lonely country road has become Allen Street, and a trolley car line has been projected to connect the rapidly extending. suburbs with the business portion of the city.

Dandelions and daisies and other wild flowers were early attractions, the profuse gathering of which at an early age led my elders, and particularly my mother, to predict that when the toddling youngster grew up he would favor the profession of medicine, and I was often facetiously dubbed "Dr. Sykes," in allusion to our then family physician, an herb-doctor of local reputation. In due time I was assigned a share in the household chores, and trained to perform the allotted tasks with promptness and care.

The nearest schoolhouse was a mile distant, of the conventional red type, situated as usual on the crest of a hill. In summer the school was taught by a schoolmistress, while the winter session was conducted by a schoolmaster selected for his ability to keep the larger boys in order as well as to teach the "three Rs." Some years later a schoolmistress was employed for both the winter and summer sessions. In these days the services of boys of even six and seven years were considered too valuable for farm- 
work to be sacrificed in summer for school purposes, so that to them only the winter session of the school year was available.

Despite hard work and long hours, the farm proved attractive and satisfying for a time, but at about the age of fourteen the love inspired by this free contact with natural surroundings developed a desire to know more of the animal and plant life, the soil and the rocks, and the ever changing phenomena of sky and air, than could be gained merely by association.

At the age of thirteen, after much pleading on my part, to my great delight, my father presented me with a gun. At first it merely afforded the pleasure all boys experience in being able to shoot something, either as game or on the pretext that certain birds and animals are destructive to crops, and that it is desirable to reduce their numbers. But very soon the destructive instinct gave place to a desire to possess specimens for study, particularly of birds, which I found were so numerous in kinds that comparatively few of them were known by name to any of the people, either of town or country, whom I met. Warblers, vireos, kinglets, sparrows and many other kinds of birds were shot, measured, weighed, described and given provisional names in my notebooks, so that I might again recognize them when met with, long before I knew that books had been written about them and that they all had names, Latin as well as English. I even made attempts to draw and color them, but entire lack of instruction in the work led only to failure and disappointment. A little later, however, I made the acquaintance of Bradford Horsford, a teacher of drawing, who was also an amateur ornithologist and taxidermist, with a good knowledge of all the commoner birds. From him I borrowed a copy of the Brewer edition of Wilson's 'American Ornithology,' which, to my unspeakable delight, he later sold to me; Nuttall's and Audubon's works on North American birds were also found in the public library of Springfield, and a new world was opened to me!

A little later I made the acquaintance of a man of broader education than I had ever before met, who taught our district school for several winter terms, and became a resident of the neighborhood. As he was a nature-lover himself he could appreciate my aspirations, and most generously presented me with a copy of Blythe's 'Cuvier's Animal Kingdom,' a work of which I previously had never heard. Thus equipped, and with the resources of a public library now at my command, acquaintance with not only the local birds, mammals, reptiles and fishes, but with many of the insects, became a delightful experience. Interest in farm work as an occupation as rapidly declined, but a filial desire to share fully in the fr mily burdens led to no neglect of duties but often to excessive effort in manual labor to demonstrate an interest otherwise unfelt. 
In winter I usually attended the district school, but was so far in advance of all the other pupils that I was in a class by myself in most of the branches taught, and received little aid from the teacher. A large part of my last term in the district school was devoted to solving the "miscellaneous examples" at the end of Greenleaf's higher arithmetic, then commonly in use in the schools of the region, and in such other school arithmetics as I could borrow from friends who had long since finished their school days. One winter was spent entirely at home ( $I$ was then probably in my fifteenth year), in the study of such natural history books as I could command, and of a borrowed copy of Webster's unabridged dictionary, from which I copied a large part of the natural history definitions.

\section{At Wilbraham Academy and Home Studies (1858-1862).}

Then followed several winter terms at the Wilbraham Academy where I selected my own studies, which included at first physiology, natural philosophy, astronomy, and chemistry, in addition to English grammar and arithmetic; later rhetoric, algebra, Latin, French and German were substituted for the natural sciences. Humboldt's 'Cosmos' (in English), and works of similar character constituted my favorite reading outside of my school work.

My summers were still spent on the farm, where, equipped with elementary works on meteorology, geology and mineralogy, I had ample food for thought. Lyell's 'Principles of Geology,' Dana's 'Mineralogy, the 'Proceedings' of the American Association for the Advancement of Science (the full series as far as then published), and various State geological and natural history reports were studied with avidity.

During this period my ever present ambition was to write a history of the "Birds of New England" that should be as complete and exhaustive as possible, and based on original observation, including the necessary explorations in northern New England where so many of the migratory species were supposed to pass the breeding season. Next to this I looked upon editorial work as an enviable goal. Yet at the time these aspirations began to develop composition was a slow and difficult task, and to acquire facility in writing I forced myself to keep a daily journal, in which I recorded not only the current weather conditions in detail but every incident of my daily experiences that seemed to offer a subject for comment.

In Professor Oliver Marcy, teacher of the natural sciences at Wilbraham Academy and later professor and finally dean of the faculty at Northwestern University, I found a most sympathetic friend and counsellor. It was 
he who first secured my introduction to the public through the 'New England Farmer.' It was my custom at the Academy to offer, when composition day came round, some of the results of my natural history observations as a composition. One of my first offerings of this sort was a summary of my weather journal for the previous seasonal period of three months. When the time came for the return of compositions mine was withheld with the request from Professor Marcy, who had charge of my division, that he might retain it for a short time. A few days later he handed me a copy of the 'New England Farmer' containing my article, printed in full and without change, with a very complimentary introduction by the editor. It was to me an exceedingly great surprise, and sufficient explanation of why my composition had not been returned to me at the usual time. I was at this time about eighteen or nineteen years of age.

With this cordial welcome from the editor of the 'Farmer,' I mustered courage to offer, soon after, other contributions of a similar character, my weather reports thereafter appearing at regular intervals till circumstances prevented the continuation of the observations. These articles were followed (in 1859) by others on quite different subjects, including a series of twenty-five on New England birds; also a paper on the moon's alleged influence upon the weather, in reply to previous articles on the subject by other contributors. My article was based on meteorological observations kept at the United States Armory at Springfield, Mass., for a long period of years, latterly by Mr. Joseph Weatherhead, who kindly placed them at my disposal for study. It is needless to say that $I$ found no evidence of lunar influence on the character of the weather, and no basis for sundry other assumptions regarding the moon's influence on mundane life, or for popular beliefs respecting the proper time in the moon for weaning pigs, colts and calves or planting crops.

During these years I spent much time studying botany, adding a collection of dried plants to my other natural history gatherings, nearly all of which I was able to identify without other aid than Gray's well-known 'Manual of the Botany of the Northern United States', my copy of which eventually became well annotated with my field notes. At this time I had not the acquaintance of any one who had any knowledge of the scientific names of plants, or who, so far as I knew, cared to know them. I still recall the exquisite pleasure it gave me to discover the name of some wild plant I had long admired in total ignorance of its affinities or name.

During the years 1859-1861, I collected and mounted (as attested by my catalogue, still extant) some 300 birds, representing nearly 100 species, and also such native mammals as I could find near my home, and I preserved in jars of alcohol specimens of all the reptiles, amphibians and fishes; 
such mollusks as were available were also gathered and several hundred insects. Best of all, I knew the technical names of nearly all except the insects, of which, however, I knew many. The local minerals and rocks found place on the shelves of my little museum, for which a small room was kindly provided by my parents, and which I equipped with shelves and a flat table case for insects. In addition there were rows of bottles containing the products of my boyish experiments with such cheap chemicals as I could afford to purchase at the neighboring drug stores, each duly labeled with its proper chemical formula. The whole was amateurish in the extreme, and repressented merely a superficial acquaintance with a wide range of subjects, but enough to add immensely to the pleasure of living, giving, as it did, the sense of being in touch with the plant and animal life and the geological features of my immediate environment. My notebooks contained pages of descriptions of unusual atmospheric phenomena, from the prismatic tints of fleecy clouds floating past the midday sun, haloes, unusual storm conditions, auroral displays, and the August and November shooting-star periods, to the varied forms of the snow crystals of a winter storm - things for the most part unobserved by my friends and neighbors, and which hence gave them no added joy to living.

It is needless to say that my interest in every day practical affairs was limited to a conscientious and cheerful discharge of the obligations natural to my position as a helper to my father in the routine of farm work. Every spare moment of the day when in the house was spent in my room poring over books or specimens or jotting down things seen out of doors in the corn or hay field. These constant disappearances when off duty were naturally an annoyance to my father, who could not appreciate my absorption in such unpractical affairs. To the oft-made inquiry of my Father, "Where's Asaph?" was Mother's gentle response, "upstairs," and the contemptuous paternal rejoinder: "Upstairs; he's always 'upstairs.", Although unappreciative of his son's "foolish notions," he was not harsh or unkind, as an agreement, lasting for several seasons, granting one day a week for the prosecution of my hobbies is ample evidence. For these foibles my mother had always a degree of sympathy, which increased as years passed to active influence in their behalf.

To demonstrate my hearty interest in forwarding the farm work, I often as I afterwards found, exerted myself beyond my proper physical endurance, which with the absorption in my natural history work told heavily on my health. It was often necessary in the busy season for my father to employ day laborers and it was always my ambition to "lead the field," which I was always able to do except in the heavier work, even when a young boy just entering the teens. My evening task, before retiring, was 
to write in my journal the notes of the day and to change the dryers in my extemporized botanical press, consisting of several pieces of thick board, cut the proper length, a lot of old newspapers, and a heavy, smoothly waterworn stone for the top of the pile to afford the requisite pressure. Many, many a time this bedtime task found me almost too exhausted by the day's labor to accomplish. These long periods of overwork undoubtedly laid the foundation for much of the semi-invalidism of many later years.

There was, of course, respite in seasons when farm work was not pressing, when much spare time could be found for collecting trips and the preparation of specimens. My excursions were generally limited to the radius of a few miles from the farm, adjoining which, in my early days, were a few small patches of virgin forest. But the ax had already begun to thin their ranks, and before my collecting days had fairly begun, these grand old remnants of former forest conditions were swept away and the land devoted to farm purposes or allowed to grow up in a shrubby second-growth.

My excursions extended to the famous new-red sandstone quarries in East Longmeadow, my first visit to which is still vividly remembered. Other trips were made to Mount Tom, with boon companions - sportsmen who had become amateur taxidermists and enthusiastic general collectors of birds, beasts, fishes, reptiles and insects, for the Springfield Museum of Natural History, under the auspices of the City Library Association. ${ }^{1}$ One memorable trip of several weeks duration was made to visit relatives in Windsor County, Vermont. The physical character of the country was in strong contrast with that of my home surroundings, and the fauna and the flora were perceptibly different. Most interesting of all the many excursions in this new field was the ascent of Mount Ascutney, and many samples of the rocks of the general region visited were taken home for my cabinet. A second trip to this region, made in August of a later year, included a visit to the gold washings at Springfield (Vermont), where I spent a night in camp and gained much valued information respecting the methods there employed in securing the precious gold dust and diminutive nuggets that barely paid for the time and labor expended.

My several terms at Wilbraham Academy prior to the winter of 1861-62 had been a serious draft upon my father's limited resources, with interest still to be met on farm mortgages and a considerable family to support, and, eager as I was for such advantages, I could not consent to accept his

1 These men were Caleb W. Bennett, a house and sign painter, who will receive later mention in this narrative; Solomon Stebbins, a paper hanger; and Charles Emery, a draughtsman at the U. S. Armory at Springfield. Their leisure time was holidays and Sundays, which they intelligently and enthusiastically devoted to natural history collecting, and their evenings to the study and preparation of specimens for exhibition in the Springfield Museum. 
further aid. I had my little museum, so dear to me that it had seemed impossible to part with it under any circumstances. In this emergency it occurred to me to offer to sell the collection to Wilbraham Academy, and use the proceeds for my school expenses. To my surprise as well as delight, the offer of sale was accepted, and to this extent my way was clear.

\section{Special Student under Louis Agassiz (1862-1871).}

On again entering the Academy I found a congenial spirit, whose tastes and aspirations were similar to my own, but under better guidance, as my new friend ${ }^{1}$ was a nephew of my loved teacher, Professor Marcy. He was planning to enter the Lawrence Scientific School at Cambridge, to become a pupil of the great Agassiz. Why should not I do the same? The balance still due me for my collection, if paid to me in cash would enable me to establish myself at Cambridge, on our proposed plan of hiring an inexpensive room and boarding ourselves. The necessary preliminaries having been arranged, we arrived in Cambridge early in February, 1862. I well remember plodding through the knee-deep snow of Divinity Avenue to reach the Agassiz Museum, in exceedingly inclement weather, and our cordial greeting by the great scientist. Plans for laboratory work were at once arranged, and also for attending certain of the courses of lectures at the Lawrence Scientific School that were to form a part of our curriculum. Besides those of Agassiz himself we were to attend the course by Jeffries Wyman on comparative anatomy, a course on physics by Joseph Lovering, a course on chemistry by Josiah P. Cook, and the course on botany by Asa Gray, all eminent specialists of world-wide renown.

I had naturally chosen as my specialty the study of birds, and was not a little disappointed at having assigned to me the same task as that set for Mr. Niles. We were both given collections of corals of several genera and requested to find out their methods of growth and laws of development. Not a hint was given us as to what details we were to look for, and no books of reference were suggested. The first lesson, we were told, was to learn to observe, to use our eyes. Equipped with hand lenses, we proceeded to our task. After a few hours of application we were asked "Well, what have you seen?" and the same query was daily repeated. We reported what we thought we had discovered, and if we had seen aright we were encouraged with a few words of approval; if we were mistaken

\footnotetext{
1 William Harmon Niles, of Worthington, Mass., later for many years professor of Geology and Physical Geography at the Boston Institute of Technology.
} 
the reply was "You are wrong; you must look again; you must learn to see."

We were not left, however, without friendly words of intercourse about other matters. The great master was engaged with his own work in the same room, which was in the southeast corner of the first floor of the first section of the Museum, of which this was at that time the only part constructed. Agassiz was then engaged in studying the great DeKonink and other large collections of fossil mollusks, at that time recently received and not fully unpacked. From time to time he gave expression to his delight over some new discovery, and to the trays containing the specimens and their labels were frequently added new labels of his own, on which the name of a new genus or a new species was written, as the case might be. His workroom, or laboratory, was almost daily the resort of eminent scientists: Jules Marcou was almost a daily visitor, when the conversation was always in French; Jeffries Wyman was a frequent caller, as was also Benjamin Pierce, the eminent mathematician; on the days when Agassiz gave his lectures many distinguished notables from Boston were present, among. whom was frequently Oliver Wendell Holmes.

Besides Agassiz and his French artist Bourkhart and ourselves, the room was occupied by the osteological preparator Guggenheim, with whom conversation was always in German. For many years this old German worked at preparing fish skeletons for the Museum, whose eccentricities of dress and habits will be long remembered by the Agassiz students of that early day. He was an inveterate smoker and snuff-taker, wore a wig, and made his midday coffee amid the débris of his work.

Time at first passed slowly with the two new students. They had been given a difficult problem, and weeks passed with little progress in its solution. It was a trial of persistence, of character, as well as of keenness of observation, a test to show whether the interest of the student was real or imagined. While our efforts were at times disheartening in their results, perseverance and continued application won the day. Gradually we saw the light and were able to show, each in his particular problem, the successive stages of growth in the young coral, and discovered the law governing the multiplication of plates in the successive stages of growth. We were then given other subjects to study, Mr. Niles taking up crinoids, while I was given a large miscellaneous collection of fossil gastropods to assort and arrange according to their relationships. We were both happy, having. been assured by our great teacher that we were making good progress in "learning to observe."

Soon, however, I contracted a bad case of measles, which ended in serious impairment of my eyes, from which I suffered for years after. For 
some six months it was impossible for me to read ordinary print, and for several years I could not use my eyes for evening study.

I returned to my Springfield home early in May, equipped with tanks of alcohol (the well known 'Agassiz tanks') for the preservation of specimens. Although in wretched health, suffering from chronic indigestion as well as from weak eyes, I collected over four hundred specimens of animals, chiefly vertebrates, and largely birds, besides taking a share in the farm work.

On my return to the Museum in the autumn I ventured to express my strong desire to study birds. The condition of my eyes, however, was a great handicap. The mammals and birds were in charge of A. E. Verrill, then a student at the Museum (later professor of zoölogy for many years at Yale University), who was requested to assign me material for study. The collection of birds consisted at that time of several hundred skins (possibly a thousand or two, all North American), and several thousand in alcohol, nearly all uncatalogued and the alcoholics unidentified. I began with the identification and cataloguing of the alcoholics, which occupied most of my time for many months, and really extended over years, as new collections came in. I soon acquired facility in recognizing birds in obscure plumages after long storage in alcohol, their feathers wet and colors disguised. It was, therefore, good training in the art of "learning to see." My weak eyes, however, prevented study at night, and even the little writing required in entering specimens in the catalogue often entailed much suffering. I attended numerous courses of lectures, but my progress in acquiring further knowledge of languages, so essential to a scientific student, was for a considerable time at a standstill.

At this time, by direction of Professor Agassiz, I took up the study of Pterylography, with the aid of C. L. Nitzsch's classic 'System der Pterylographie' (Halle, 1840), and made many preparations in illustration of the subject from both fresh and alcoholic material, with a view to the publication of an extended illustrated monograph of the Pterylography of the Owls. Illness, however, retarded the work, and other interests and duties intervening, it was never completed. But the investigation proved of great use to me in subsequent work in ornithology. ${ }^{1}$

Thus the time passed during the next two years and a half, my vacations being spent at home collecting specimens for the Agassiz Museum. For

\footnotetext{
1 Professor Agassiz thus refers to the subject in the Annual Report of the Museum of Comparative Zoölogy for the year 1863, p. 17: "Ill health has also taken away Mr. Allen from his field of labors. I regret it the more since he has made excellent progress in Ornithology and promised to become a valuable assistant in the arrangement of the specimens of birds. He has left unfinished a very interesting investigation upon the structure and arrangement of the feathers of birds."
} 
assistance rendered in cataloguing and in other routine work at the $\mathrm{Mu}$ seum, a monthly allowance was received sufficient for my necessary living expenses, together with a furnished room in the Museum dormitory, known as 'Zoölogical Hall,' at that time the home of the student assistants of the Museum.

During the summer of 1864 I made a trip to Sodus, Wayne County, N. Y., where several weeks were spent with relatives. The region, bordering Lake Ontario, was originally heavily forested, and some of the virgin forest still remained. The type of country was new to me and intensely interesting. A large collection of the land and fresh-water mollusks was gathered and eagerly studied, and a few insects, mammals and birds were collected, including a few species of both mammals and birds I had not before seen in life.

\section{With the Agassiz Expedition in Brazil (1865).}

During the winter of 1864-65, Professor Agassiz's usual vigorous health began to give way under the strain of years of incessant work and care, so that a change of scene and some degree of relaxation became imperative. A generous Boston friend of means (Nathaniel Thayer) suggested his making a journey to Brazil, and offered to provide the means not only for his own expenses but also for a small corps of assistants. This kind offer he accepted. It was then early in March, 1865, and the expedition was to start as soon as the necessary preparations could be made. On March 12 he asked me if I would like to join the expedition. Naturally I accepted the unexpected invitation, and was instructed to join three other Museum assistants who had also been invited to accompany the expedition, and meet him, with them, at a designated place in Boston to arrange for our passports. Thus suddenly opportunity opened to us for exploration in a distant land. We left Boston for New York on the evening of March 26, and sailed for Rio de Janeiro on April 2, on the steamship 'Colorado,' of the Pacific Mail Steamship Company. The 'Colorado' was a new vessel, of 2000 tons, then regarded as remarkably large and luxuriously furnished. This was her maiden voyage, and Professor Agassiz and his party of sixteen persons were the only passengers.

As we passed down the coast of Virginia, on April 3, heavy masses of smoke were seen over the western horizon, which the Captain of the 'Colorado' believed to indicate a distant battlefield. But it was not till May 16 that news of the fall of Richmond reached us in Brazil and confirmed the Captain's surmise that the smoke we saw on April 3 was from a great battle - the closing contest of the civil war. 
Early in the voyage Professor Agassiz began a series of lectures, which was continued almost daily till we reached Rio de Janeiro, dealing in turn with the Gulf Stream, the Sargosso Sea, embryology, and the classification of the animal kingdom. We arrived at Rio April 22, after an exceptionally pleasant voyage.

Save for a few excursions, by rail or boat, to near points, the whole party remained at Rio for several weeks, but work was organized immediately on our arrival and collections of specimens were gathered daily in the surrounding suburbs. At the same time preparations were under way for the various projected expeditions into the interior that were to occupy us the rest of the year. Besides the six trained assistants from the Museum, as many other young men were attached to the expedition as volunteers; all were duly assigned positions on the different exploring parties. $^{1}$

Following several short excursions from Rio, including a two weeks' trip to Mendez and the Barra do Parahyba, on the Dom Pedro II railroad, some 60 miles from Rio, I was assigned to one of the parties that was to visit the northern Provinces of Brazil. We left Rio de Janeiro June 9 for Petropolis, a beautiful mountain suburb of Rio, where we spent the night. ${ }^{2}$ The following morning we resumed our journey by a mule-drawn stage for Juiz da Fora, over a perfect road, making the 100 miles in ten hours, with relays of mules every ten miles. The road traversed a highly picturesque section of country, parts of it clothed with verdure of almost Amazonian luxuriance, while flocks of toucans and large parrots frequently attracted attention.

At this point we were to outfit for our long journey into the wilderness; but instead of finding our equipment of mules and camarados awaiting us, as we had expected (it having been ordered in advance), our animals were still at distant ranches and nothing was in readiness. It required five days to assemble the mules and their drivers. It was June 15 when our little cavalcade of 14 mules, 4 horses, and 4 camarados left Juiz da Fora for the headwaters of the Rio das Velhas, some 300 miles distant.

We reached Barbacena on the third day, where Mr. Ward with his share

1 The personnel of the Expedition, in addition to Professor Agassiz, was as follows: Assistants from the Museum staff: John G. Anthony, conchologist; Charles Frederick Hartt, geologist; Orestes H. St. John, geologist; George Sceva, osteologist; J. Burkhardt, artist. Volunteers: William James, later the eminent psychologist of Harvard University; Edward Copeland, Newton Dexter, James. Hunnewell, S. V. R. Thayer, and Thomas W. Ward. D. Bourget, a French naturalist, joined the Expedition at Rio de Janeiro.

2 Our party consisted of Orestes H. St. John (geologist and chief), George Sceva, Thomas W. Ward (mineralogist), and myself. We were to travel together, however, for only a short distance, as Mr. Ward was to leave the party at Barbacena and Mr. Sceva at Lagoa Santa. 
of the cavalcade left us for Diamantina. We were delayed here several days while Mr. Sceva made a fruitless side-trip to some limestone caves at San José to prospect for fossil bones. We resumed the journey on the 24th, reaching Morro Velho July 7 and Lagoa Santa July 13, much of the way by obscure and difficult roads. Here we spent several days, collecting specimens and visiting the famous bone caverns ${ }^{1}$ made classic by the Danish naturalist, Dr. P. W. Lund, who was still resident at Lagoa Santa and whom we had the pleasure of meeting. Six days later we reached Trahiras, on the Rio das Velhas, where we disposed of our animals and outfitted with a large canoe and boatmen for the voyage down the river. This involved another delay of eight days although our river equipment had been ordered in advance and was supposed to be awaiting our arrival. But the delay had its advantages, for it enabled us to repack the collections we had made en route for shipment to the United States and gave opportunity for making a large collection of fishes, besides obtaining many birds and mammals. We received here also our first letters from home, letters that had taken three months to reach us.

We were able to secure a boat well adapted to our needs, a canoe 50 feet in length and four in width, dug out of a single tree. This we rigged with outriders and covered with canvas to protect us from the sun by day and afford shelter at night. We named her the 'Gequitibá,' an Indian name borne not only by the tree from which it was made, but by the fazenda and village from which we outfitted. We also supplied ourselves with a smaller canoe to serve as a tender. Our crew consisted of four boatmen, a cook, and an English boy we had previously secured at Morro Velha, with St. John and myself, making eight persons in all.

Our journey from Juiz da Fora (distant about 120 miles from Rio) by pack train to Gequitibá (or Trahiras), on the upper Rio das Velhas, was made in twenty days of actual travel, the distance by our circuitous route being about 300 miles, but the time occupied in outfitting for the two journeys, and in various delays en route was much more, so that the time between our arrival at Juiz da Fora and our departure down the river was about 50 days (June 9-July 31 ).

On July 31 we left Trahiras to descend the river, reaching its junction (Barro do Rio das Velhas) with the Rio São Francisco August 28. Our progress was greatly delayed by the low stage of water rendering the numerous rapids difficult, and in some instances dangerous, to pass. Nearly every day we lost several hours in exploring for channels that would permit the warded.

${ }^{1}$ Mr. Sceva was left here to make further exploration, but his search for fossils was poorly re- 
passage of our boat, and had several narrow escapes from shipwreck. These delays gave opportunity to explore the adjacent country and to make collections, particularly of birds, frogs, fishes and mollusks. The river is very tortuous, particularly in its upper course, where it occasionally returns on itself in great loops. The distance by land between Barro do Rio do Gequitibá, our point of departure, and Barro do Rio das Velhas is said to be 55 leagues or about 220 miles, and about 350 miles (estimated) by the river. Our journey down the river, we were told, was one of the quickest and most successful ever made at such a low stage of water, it being accomplished in twenty-one days, without having to unload the boat or losing any baggage. We were fortunate in our choice of boat, as with an ajojo (two boats lashed together) we should certainly have been wrecked in passing rapids, and with a barca (house boat) have been repeatedly forced to unload our freight. We had also an excellent crew of boatmen, who often took to the water and guided the boat by hand through dangerous passes.

We remained three days at the Barra, where we were obliged to get a relay of boatmen, and left September 1 for Januaria, arriving there September 9. The Rio São Francisco is about twice the size of the Rio das Velhas and unobstructed by rapids; we were hence able to make good progress, though at times delayed by strong head winds. While at the Barra we made very satisfactory collections, but spent much time in unsuccessful efforts to obtain barrels and spirits for our specimens, which we had intended to send from this point to Rio Janeiro for shipment to Cambridge. Consequently we were obliged to take them with us, in the hope of being able to send them to the coast for shipment home via Bahia or Pernambuco.

During the three months since we left Rio de Janeiro it had become evident that my physical condition rendered it impracticable for me to attempt to carry out the journey as originally planned, namely, to descend the Rio São Francisco to the Barra do Rio Grande and then cross the divide to the headwaters of the Rio Parahyba do Norte and thence reach the coast in Ceará. After long consultation we decided to divide our party, Mr. St. John to attempt to complete the journey as originally planned, while I was to remain a short time at Januaria and then continue down the São Francisco to a point from which it would prove practicable to make an overland journey to Bahia.

In accordance with this plan Mr. St. John left Januaria in our small canoe, with one man, September 14, with the alternative in mind that should it prove impracticable to make the Ceará portion of the journey he was to join me again at Barra do Rio Negro for the overland trip to Bahia. Pluck and perseverance enabled him to carry out the original schedule of the expedition, though short of funds and finally seriously ill with fever. 
I remained at Januaria till the 19th (ten days in all), having in the meantime sold our big canoe and hired a barca for the descent of the São Francisco, discharged our old boatmen and engaged others, repacked our collections for the journey to Bahia, and made several excursions into the neighboring country, which resulted in important accessions to our natural history collection and many pages to my field notes.

The journey down the Rio São Francisco was made comfortably, save for excessive heat (maximum daily temperature $80-98^{\circ} \mathrm{Fahr}$.), and without untoward incident beyond frequent delays by heavy head winds and by illness of the boatmen. I decided to terminate the river journey at the village of Chique-Chique, which point we reached in the afternoon of October 8, the descent from Januaria to this point having occupied 18 days. Chique-Chique is 530 miles below Januaria and about 580 miles from Bahia, by the overland route.

The region about Chique-Chique is excessively arid and the heat intense. It was near the beginning of the rainy season, which had already set in further in the interior, as shown by the slight daily rise of the river during my descent from Januaria. In fact, nearly the whole journey from Lagoa Santa to this point was made just in advance of the rainy season, occasional showers at different points indicating its near approach.

It was necessary for me to remain several weeks at Chique-Chique for an opportunity to join a pack-train bound for the coast, there being considerable traffic between this point and Bahia. The caravans, however, depart infrequently and at uncertain intervals. The route was by way of Jacobina, Arraial do Riacho, Jacuhipe, Villa da Feira da Sta. Anna, and Cachoeira.

The country between Chique-Chique and the coast at Bahia presents three natural regions, which are plateaus, differing widely from each other in their geological features. The first is excessively arid and extends from the Rio São Francisco to Jacobina, a distance of rather more than 200 miles. It is a vast limestone plain, practically without inhabitants, so that it was necessary to take with us not only food for the animals as well as the men, but also drinking water, which was carried in large leather water bags, as in parts of the Far East. This plain rises gradually toward the east, culminating in the Taboleira de Jacobina. To the eastward the descent to the Jacobina valley is abrupt, through a narrow precipitous defile known as the Tombador (the tumble-down). Almost vertical walls of rock, nearly a thousand feet in height, surround the head of the valley.

The second or middle plateau likewise has a breadth of some 200 miles, extending from Jacobina eastward to the Sierra da Terra Dura, a point midway between Jacobina and Cachoeira, at the head of Bahia Bay. The 
underlying rock is gneiss, with vast exposures of bare rock, and with nowhere more than a very thin covering of soil. Slight knolls and shallow basins alternate, with rarely a difference in altitude of more than twenty or thirty feet. Many of the hollows form shallow lakes in the rainy season, from which most of the water evaporates in the dry season. At frequent intervals there are circular holes in the rock, called by the natives caldeirãos, which I found on examination to be genuine pot-holes, some of them of great size (the largest one measured was 20 feet in diameter).

A considerable descent is made in passing from the middle to the eastern or coast plateau, which is characterized - at least along our route of travel - by the general absence of rock exposures and heavy superficial deposits of sand, doubtless from the abraded plains to the westward. The whole region between the São Francisco and the sea is covered, generally speaking, with low open forest, or catinga, except for a narrow belt along the coast, where a moister atmosphere permits a more luxuriant growth. The whole area presents a barren aspect, the vegetation being dwarfed and scanty and the aridity excessive. The greatest aridity and the highest temperature occurs in the limestone district, where little or no moisture is precipitated for nine months in the year, and where all the herbaceous vegetation annually withers. Cacti occur in great variety, including arboreal forms of gigantic proportions. With the exception of a few species, the trees are leafless throughout the long dry season, and the streams become dry or merely form chains of brackish pools. ${ }^{1}$ The convolvuli and other vines clinging to the arboreal vegetation, though dead at this season, indicated the presence of a wealth of flowers and foliage during the short rainy period.

Our train comprised several score of pack mules and a considerable number of riding horses. Eight animals were necessary for the transportation of my collections. The journey occupied several weeks of rather tedious travel, Bahia not being reached till about the end of November. I soon found storage in a warehouse for my collections until I could arrange for their shipment to Boston. They included several cases of bird and mammal skins, mollusks, and geological specimens, besides some six or eight barrels of fishes, reptiles and other vertebrates in alcohol. These required repacking for shipment, new casks being necessary for part of the alcoholics. Some days later, I found that my fine work in repacking was only temporary, for at the custom house an export duty of $8 \frac{1}{2}$ per cent was levied on natural history specimens, which involved the opening of my cases for inspection!

As I knew Professor Agassiz had an agent, who was also a warm personal $102^{\circ} \mathrm{F}$

1 I found the water at midday in some of the trickling streams we crossed had a temperature of 
friend of his, at Bahia, I had anticipated little trouble in arranging for my passage home and the forwarding of my collections. It unfortunately happened that he was absent at this time from the country, and also that no provision had been made for the arrival of any of the field parties at this point, and consequently that no arrangements had been made for sending home any members of the Expedition or their collections from Bahia. I was thus received as a stranger, and as my funds had become exhausted, and I was also seriously ill, the outlook was not exhilarating. It was, however, my great good fortune to find at my hotel Captain Joseph Swift, of Gloucester, Mass., a retired shipmaster now acting as a super-cargo for a Boston firm engaged in the Brazil trade. I revealed to him my straits and he immediately took me under his care, even advancing money for my expenses. He also secured passage for me on his vessel soon to sail for Boston. I shipped the collections by the steamship 'North America' of the United States and Brazilian Steamship Company.

On December 15 I left Bahia on the Hanoverian brigantine 'Gehardina,' of 300 tons, chartered here for Boston and loaded with sugar and hides by Captain Swift, who with myself were the only passengers, payment for my passage to be made on my arrival in Boston. The accommodations were primitive - a berth in the Captain's cabin under the companion-way, the fare conforming in character to what would be expected in a small sailing vessel in the commercial trade. The officers and crew were Germans, but some of the former could speak a little English. During the three weeks spent in Bahia I made the acquaintance of a number of foreigners resident in the city, among them several who were much interested in scientific pursuits, notably Dr. O. Wucherer and Charles Williams.

The 'Gerhadina' was favored for a month with fine weather and made a quick voyage as far as Cape Hatteras, with a fair prospect of reaching Boston in less than forty-five days from Bahia. But January 21, in passing the Cape, we were suddenly struck by a furious gale, which rapidly drove us off our course to the eastward. We were constantly under close-reefed sails for fourteen days, the wind shifting about every twelve hours from northwest to northeast, and back again, with tremendously heary cross seas. At the end of this period the ship had become strained and was leaking, the food supply was getting short, and as a last resource Captain Swift and Captain Aalderks decided to try to make Bermuda, then not far away. But as we had not seen the sun for two weeks, it was dangerous to trust to dead reckoning in attempting to make so difficult a port in stormy weather. So the 'Gerhadina' was soon headed southward for St. Thomas, the harbor of last resort for North Atlantic seamen in distress. In a short time we passed into smoother water and in due time reached the harbor 
of St. Thomas, which we found filled with shipping driven thither, like ourselves, by stress of weather, most of the vessels with broken masts or otherwise seriously disabled. Not a few, as we learned later, caught in this memorable storm were never again heard from, and our ship was among those reported as overdue and supposed to have been lost.

A week at St. Thomas sufficed for repairs and the taking on of fresh supplies, and gave me time to gather a small general collection of natural history specimens, and we were again on our way north, with fine weather and full sails as far as the dreaded Cape, when we again encountered heavy gales and were driven from our course. It was overcast and stormy with high winds for the rest of the voyage; we hoped we still held enough westing to make our port, but were in doubt, as we were again dependent on dead reckoning. It was therefore a crucial time when at sunset of a boisterous March day the sailors were sent aloft to shorten sail, preparatory to layingto for the night, presumably near the eastern end of Long Island, but with doubt as to whether we should not be so far off our course as to render necessary another long voyage to recover our lost westing. Shortly, however, the sailors from the topmast announced a light, and soon after a second light, thus making us sure of the position of the ship and the course to lay. The next morning the 'Gerhadina' was anchored in the harbor of Woods Hole, and a few days later ended her ninety days' voyage from Bahia to Boston.

When I left Bahia I was rather glad that the fates had determined that I was to make the voyage home in a sailing vessel, and on completing it I was still glad I had had the opportunity of such a varied experience. I had seen the ocean for weeks in its most amiable moods, and I had seen it again for weeks in its most angry paroxysms. The trade-wind belts, the doldrums with their huge, slowly rolling swells, the North Atlantic in its February anger, were all precious memories. The Sargosso Sea had added specimens of the surface life of the sea to my collections - minute mollusks and a varied assortment of crustaceans gathered from the gulf weed - and many observations on sea-birds, flying-fishes, and the atmospheric phenomena of midocean.

\section{Collecting Trip to the Middle West (1867).}

During the last two months of the voyage my health naturally improved, but I had suffered so long from chronic indigestion and intestinal troubles, and especially during my journey in Brazil, that I finally felt it best to try and abandon my ideal of a life devoted to natural history research, and accordingly resigned my position at the Museum of Comparative Zoölogy 
and returned to the farm. Nith this change of occupation my health improved, and with it my old love strengthened. During the winter of 1866-1867, the point of non-resistance was reached, and I planned a natural history collecting trip to the Middle West, in parts of which several of my mother's brothers and sisters had settled as pioneers, thus affording me convenient bases from which to prosecute my work. I was successful in securing orders in advance for specimens of both animals and plants, and so successful in filling the orders that after thousands of miles of travel and the acquisition of a most valuable experience I returned home free of debt, and therefore perfectly satisfied with the results. This trip furnished material for several faunal papers, published in the 'Proceedings' and 'Memoirs' of the Boston Society of Natural History.

The month of May was spent near Sodus Bay, on Lake Ontario. During June the Chicago Academy of Sciences was the point from which excursions were made into the adjoining country, including a trip to Richmond, Indiana, where as a guest of a fellow naturalist, I passed one of the most enjoyable weeks of my life, collecting fossils as well as birds, insects and shells. Several weeks were spent in north-central Illinois, and also in the vicinity of Des Moines, Iowa. During most of July and August I was a guest of the Iowa Geological Survey, through the kindness of the State Geologist, Dr. Charles A. White, and of his field assistant, my friend Orestes H. St. John, who had been a fellow-student with me at the Cambridge Museum and my companion on the Brazil expedition. I accompanied him during his reconnaissance of an area about sixty miles square in southwest-central Iowa (mainly the nine counties of Dallas, Guthrie, Boone, Greene, Carroll, Crawford, Sac, Calhoun and Audubon), the greater part of which region, and thence westward to the Missouri River, was still practically an unsettled wilderness. Our camp wagon was our sole shelter and our immediate source of supply, and our teamster-cook our only human associate for many days together. Here I made general collections, but for the most part found plants and insects the most profitable, securing during the trip several species of each that proved to be new to science. On my return I spent a few weeks in southern Michigan, and made another short stay at Sodus, N. Y.

This out of door life proved of great benefit to my health, and while still in the West I wrote to Professor Agassiz that I felt again equal to resuming my duties at the Museum of Comparative Zoölogy. His response was a most cordial invitation to return, and in October I resumed my post, where I remained uninterruptedly for the next eighteen years, except when in the field on Museum expeditions, as noted in the following narrative. I had already been placed in charge of the departments of mammals and birds 
when I accompanied the Agassiz Expedition to Brazil, in 1865, and in 1871 was promoted to the official status of "assistant in ornithology," and continued as acting curator of mammals and birds till my resignation in 1885 to assume similar duties at the American Museum of Natural History in New York.

\section{East Florida Expedition (1868-1869).}

In the winter of 1868-1869 I conducted a three month's exploration of the country bordering the St. John's River in eastern Florida, between Jacksonville and Enterprise, which furnished the basis of my paper 'On the Mammals and Winter Birds of East Florida,' etc., published in the 'Bulletin' of the Museum of Comparative Zoölogy (April, 1871). This journey was made, with two volunteer assistants, in a ship's yawl fitted with a large sail. As the country was then only slightly settled above Pilatka, our boat was our home and base of supplies, but at times we occupied rude huts that had been deserted by their former occupants. Parakeets were still abundant, and alligators had almost undisputed possession of the bayous and river banks. At certain points of our journey no human beings were seen for many days together except the members of our own party.

\section{Assistant at Museum of Comparative Zoölogy (1871-1885).}

\section{Great Plains and Rocky Mountain Expedition (1871-1872).}

In April, 1871, I started on a nine months' collecting trip to the Great Plains and the Rocky Mountains, in the interest of the Museum of Comparative Zoölogy, with two assistants, Richard Bliss, a fellow-student at the Agassiz Museum, and Caleb W. Bennett, of Springfield, Massachusetts. Mr. Bliss returned to Cambridge about the beginning of August, Mr. Bennett remaining with me, as hunter and taxidermist, till the end of the expedition in January, 1872. General collections were made at intervals from the Missouri River to Great Salt Lake, Utah. As western Kansas was then subject to raids by hostile Indians, we were provided with letters of introduction from Major-General Pope, Commander of the Department of the Missouri, to the commandants of the military posts near our proposed route in Kansas and Wyoming, requesting them to aid the expedition by providing escorts and transportation, should such assistance prove necessary. Accordingly Fort Hays was selected as the most convenient base from which to hunt buffalo, where a vacant suite of unoccupied officer's quarters was assigned us for use during the six weeks we spent at this point, making collections of the most varied and comprehensive character.

We began work at Leavenworth, where we spent the first ten days of 
May, and then went to Topeka, remaining there about two weeks collecting, chiefly birds, fishes, reptiles, and insects. We arrived at Fort Hays May 26 , where we remained till July 3 , becoming well acquainted with the surrounding country while waiting for the military escort we were assured was necessary for our safety in going out to the buffalo range, some thirty miles northwest of the post. The cavalry, however, was absent on escort duty with government supply trains and the date of their return was tantalizingly indefinite. While waiting for several weeks for this alleged essential to our buffalo work, we made the acquaintance of Charles Clarkson, a professional buffalo hunter who for several years had hunted buffalo in winter for shipment to the eastern cities. This intelligent, enterprising and level-headed New Englander, who lived in a dugout on the outskirts of the military reservation, who owned a good pair of mules and a wagon, and was familiar with the ways of the Sioux Indians, assured us it would be quite safe to go on a buffalo hunt without the encumbrance of a military escort. As he was willing to act as our scout and hunter and furnish us with the necessary transportation for a reasonable consideration, we deemed it safe to trust to his judgment regarding the risks entailed.

We left Fort Hays on our buffalo hunt June 21, returning four days later with a wagon load of buffalo skeletons and skulls, besides leaving on the open prairie five skeletons we had prepared that we were unable to bring with us for lack of room. As we still needed an old cow, and had secured no calves, Clarkson and I returned to the buffalo range the next day, and at the end of another four days had completed our desiderata, having not only secured a fine old cow skeleton and a number of young calves, but had also retrieved the skeletons left on our former trip, which, however, we found had been somewhat damaged by coyotes. In all our spoils numbered 14 complete skeletons and several additional skulls, representing both sexes and various ages, from yearlings to old bulls and cows; also the skins as well as skeletons of five young calves. The time thus occupied was eight days, involving about thirty-six hours of travel. We saved no skins, except those of the calves, as at this season the old coat had been shed (except of course on the shoulders and head) and the new coat was so short that it barely concealed the skin.

The experience was one long to be remembered, as we took no camp outfit but our blankets, a little flour and canned fruits, depending naturally upon buffalo meat for our main subsistence, buffalo chips supplying us with fuel. Our blankets were our only shelter at night, and our wagon was the only arailable screen from the hot midday sun, under the shade of which we crept to eat our dinner. ${ }^{1}$ We saw no Indians, but the landscape was every-

${ }_{1}$ Temperature $105^{\circ} \mathrm{F}$. in the shade on one occasion, and usually over $100^{\circ}$ at midday. 
where dotted with small bands of buffalos; which were so numerous on one occasion that they darkened the plains to the west of us as far as the eye could reach. They were given no peace by the skin hunters, several parties of whom we met on the range. The skins then sold for two dollars each at the nearest railroad station. Once a small band of buffalo, stampeded by these hunters, sent us to our wagon for safety, the herd passing on both sides of us almost within arm's reach.

On returning from the buffalo hunt we packed the collections we had accumulated at Fort Hays and shipped them East, part to Rochester for preparation and part direct to the museum at Cambridge. July 3 we took the train for Denver, and at daylight the next morning obtained our first view of the Rocky Mountains, the snowfields on the higher peaks coming clearly into view with the rising of the sun. We spent two days at Denver, outfitting for a wagon trip into the mountains, and left for South Park on the afternoon of July 6, camping the first night on Turkey Creek, just behind the first range of foothills. While in Denver we had noticed a band of about 300 Ute Indians, encamped on the outskirts of the city, who had come in to receive their annual supplies from the United States Government, and to barter their robes and other furs with the people of Denver. They swarmed through the town on horseback, men, women and children, clad in their native costumes, their faces painted, and their persons decorated with beads and brass and tin trinkets. They were nearly all bare-headed, their coarse jet black hair reaching usually to their shoulders. Some wore hats, or hats and coats, and a few full suits of white man's clothes, but usually a deer skin or a woolen blanket wrapped about them was the principal article of clothing. It was our first sight of the red man in his native splendor and naturally these Indians greatly interested us. But great was our disgust to find that they had left Denver for the mountains just ahead of us and were encamped only a few hundred yards beyond the place we had chosen for our own camp. While they might be 'honest Indians' our guide deemed it best for us to keep a sharp lookout for our horses and other belongings. We decided to stay in camp in the morning till they passed on. They broke camp early and we did not anticipate meeting them again. In this we were disappointed, for we found they had gone only a few miles and again encamped. Thus we passed and repassed each other's camps for several days, until we decided to remain for some time at a point that offered good collecting, in the hope that they would continue on their journey and we should be rid of their visits. But this plan failed, as we again overtook them and they later became once more a nuisance. They were friendly, indeed quite too familiar, and inveterate beggars, particularly for tobacco and matches. 
Our journey to South Park was of great interest, not only for its scenic features but for the transitions in the fauna and flora as we advanzed to higher altitudes. We reached the base of Mount Lincoln, at the northern end of the Park, July 19, where we camped for a week, extending our collecting trip to above timber line. On the top of Mount Lincoln we found the pipit (Anthus rubescens) breeding, and collected specimens of a new species of rosy finch (Leucosticte australis), and at timber line, in the taluses obtained about thirty specimens of a new pica (Ochotona saxatilis Bangs, described in 1899 from the specimens we collected in 1871). We returned from South Park by way of Pike's Peak, Manitou Springs and the Garden of the Gods. ${ }^{1}$ We remained here nearly a week collecting and thence proceeded along the outer base of the foothills northward to Denver, where we arrived August 18, the trip having occupied a little more than six weeks.

Our next collecting point was Cheyenne, where we spent ten days, and then Bennett and I (Mr. Bliss having returned to Cambridge) went direct to Ogden, Utah. This was our base for the next seven weeks, from which we made excursions to the northern end of Great Salt Lake. Here we found avocets, stilts, phalaropes and other marsh and shore birds plentiful, and an abundance of ducks, terns and gulls. We also obtained many fishes, mollusks and crayfishes.

October 9 we took the train east to Green River, where we remained till the 17th. Here we also secured many fishes from pools and streams, and made a considerable collection of fossil fishes from the famous Green River shales, but high winds, ice and snow rendered collecting difficult.

From Green River we went to Fort Fred Steele, arriving at 3 A. M., October 18. This was the point we had selected from which to make our departure into the mountains for big game. We soon found, however, that this plan was impracticable, owing to the expense and the uncertainty of the results. Fortunately at this juncture I met Messrs. Ferris and Hunt, professional hunters, who were supplying game to the eastern markets as a business. I soon made an agreement with them to furnish a specified number of the various kinds of such big game as could be obtained in this region, for a certain price per head, to be delivered to us at Percy, a station on the Union Pacific Railroad about thirty miles east of Fort Steele.

After packing and shipping the collections made at Fort Steele, which included among other things several boxes of fossils, we went to Percy, where we remained from October 20 till December 18. Percy consisted at this time of the railway station, a small hotel, and one or two occupied log-cabins and many vacant ones, - all that was left of what a few years

1 There were only a few log-cabins and a post-office at the present site of Colorado Springs, and Manitou was merely a name. 
before, while the Union Pacific Railroad was under construction at this point, was a booming railroad town. Some of the houses were in decay and others had been removed, but the evidences of its former activities were shown by those remaining and the characteristic debris of tin-cans, empty bottles and other refuse. We hired for our workshop a log cabin that had previously seen service as a saloon, as it was large and fairly well lighted. It served our purpose admirably. Here for two months we worked six days a week in preparing the big game delivered to us at frequent intervals by Ferris and Hunt, as per contract. About one day in seven we devoted to hunting, and added thus to our spoils several antelopes and coyotes, jack-rabbits and cottontails, besides many birds, including a large series of sage grouse, then so abundant that Bennett and I, on one occasion, shot thirty in an hour - all we could carry to camp, and could have killed as many more the next hour had we needed them. As no hay or similar material could be obtained at Percy, we had to substitute dry grass for filling the skins of the mammals, and to obtain this we had to tramp to a moist ravine a mile and a half away, cut it with our hunting knives and carry it home on our backs. A journey of a hundred miles by rail to Laramie was necessary to obtain material for packing cases, namely, discarded dry-goods boxes, which we dismantled and shipped as freight to Percy and remade to suit our needs. Roughing out skeletons and preparing skins of deer, elk, mountain sheep and antelope occupied our time and kept us confined to our laboratory for the greater part of these eight weeks, but our enthusiasm was well sustained by the results, and now and then a day's tramp through the sage brush and snow relieved the monotony.

Our shipment of 17 large cases from Percy included skins and skeletons of 8 elk, 12 black-tailed deer, 1 white-tailed deer, 25 prong-horned antelopes, and 11 bighorn sheep; also 35 skulls of antelope and a fine series of the skulls of elk and black-tailed deer, besides small game (coyotes, foxes, porcupines, beaver, rabbits, etc.) and birds. It nearly filled a freight car, and was shipped on December 17, but, as will be explained later, did not reach its destination for several months.

On the 19th we took an east-bound train for Omaha, already twelve hours late when it reached Percy. A mile and a half east of Percy we ran into a snowbank and the train was partly derailed and delayed for another two hours. Between Carbon and Medicine Bow we were again stalled in the snow for twenty-two hours, where we had to await the arrival of a wrecking train, and two engines to replace our disabled ones. We got our first square meal in two days at Sidney. We struck another heary snowstorm at North Platte, and at Elkhorn, near Omaha, it was necessary to 
divide the train to overcome the heavy grade. When we reached Omaha at $9 \mathrm{~A}$. $\mathrm{M}$. of the $22 \mathrm{nd}$, the train was nearly three days overdue. It was also the last train that made the run over the Union Pacific Railroad that winter, owing to a snow-blockade which lasted for several months.

As I had already made an arrangement by letter with Clarkson of Hays City for a winter buffalo hunt, we left Omaha for Kansas City at 4 P. M. of the same day, reaching Kansas City at 4 A. M. of the 23rd. Here I obtained free passes to Ellis and return for Mr. Bennett and myself, and transportation for our specimens on the return trip to Kansas City at half rates, and thence east to Boston by the Merchant's Union Express Company on the same terms. At 10.45 P. M. we were again on a train bound west over the Kansas Pacific. At 11 A. M. the next day we were stalled in a snow drift near Bunkerhill. At Bunkerhill we found five freight trains, eleven engines and a snowplow stalled in the snow. At 3 P. M. orders were received for all trains to remain here till the storm abated. At 8.30 A. M. the next day (December 25) our train, equipped with a snowplow, started on its journey (temperature $12^{\circ} \mathrm{F}$. below zero), but in an hour we were again stuck fast in the snow in a cut, but were finally pushed through by two freight engines attached to the rear end of the train. A delay of an hour at Fossil, for switching, gave the passengers, at 11 A. M., an opportunity to procure a luncheon of crackers and cheese,- - our Christmas dinner and the first food we had had since the previous evening.

We reached Hays, thirty miles west of Fossil, that evening. Within sight of the station were five stalled trains, each with two locomotives. Behind us were two freight trains with 'double-headers,' and two snowplows, one propelled by three engines and the other by four. During the following night the wind refilled the cuts behind us between Walker and Bunkerhill, causing another blockade.

On the 26th I went to Clarkson's ranch and found he was at Coyote, fifty miles further west; but there was no train west till the evening of the 28th, when we reached Coyote, at 9.30 P. м. Fortunately the weather had now moderated, and on the 29th we went to Clarkson's camp and made arrangements with him for another buffalo hunt. At this time we were in quest of skins for mounting; our summer hunt, as already stated, was primarily for skeletons. Two weeks earlier buffalo had been abundant as far east as Coyote, but they had been so relentlessly persecuted by hunters that they had moved west and were now massed chiefly between Sheridan and Wallace, about one hundred miles to the westward. Between one hundred and one hundred and fifty hunters were said to be in constant pursuit of them. It was roughly estimated that at least 15,000 buffalo had been killed along the Kansas Pacific Railroad during the year (1871). 
We were prepared to start on our hunt on the morning of December 31 , but the weather turned severely cold and delayed our departure till the following day, January 1, 1872, when we drove south with Clarkson's outfit for nine miles and then returned, finding no buffalo, and being assured by hunting parties we met that there were no buffalos in that direction. We lunched at Coyote and then drove north nearly to the Saline River, camping for the night six miles north of Coyote, and the following night on the South Fork of the Solomon, 30 miles from Coyote. The next morning we went northwest, along the divide between the Saline and the Solomon, to a point opposite Buffalo Station, thence turning north and camping on the North Fork of the Solomon. We saw no buffalo, but were informed by returning hunters that there was a large herd six or eight miles to the northward, where a band of Omaha Indians were hunting them. The next night we camped on a tributary of the Solomon, ten miles northeast of Grinnell. During the day's drive we saw a few buffalo about 2 P. M., and were in sight of small bands for the rest of the day, but they were too wild to permit of a near approach. The next day, January 4, we came up with the first old bulls about five miles from camp, but they were wary, and the ground was unfavorable for stalking them. The weather became suddenly threatening and the wind keen and piercing from the north. Clarkson and his partner, Alden, deemed it imprudent to go further from the railroad, as if a storm should overtake us we would be far from shelter and without wood. They decided to return toward the Saline, from which point we could easily reach shelter should a storm render it necessary. We turned southward and in a few miles came upon a small herd of buffalo, from which Clarkson killed five, Alden three, and I got an old bull. The weather continuing cold and the sky overcast, with signs of a storm, we put up our large Sibley tent, which protected us from the wind and served as our base for the next three days, during which, although buffalo were scarce, our hunters secured their loads of meat, and we obtained nearly the desired number of skins. On the return journey we secured two more, reaching Buffalo Station on the evening of the 7th. The station consisted of the section house and two freight cars, one of them fitted up with sleeping bunks and the other serving as kitchen, and a water tank and two or three dugouts. The owner of one of the latter, a buffalo hunter, happened to be absent and Mr. Bennett and I slept in his dugout. Although the entrance was ankle deep with water, and the floor also covered with water, we passed a comfortable night, such shelter as this being far preferable to sleeping out of doors in the chilling south wind then prevailing. We learned here that the buffalo had left the whole line of the railroad, presumably driven off by the 600 or more Omaha Indians we had seen encamped on the Solomon. So we felt satisfied that we had done as well as was possible under the conditions. 
We drove the next day to Coyote, where we finished preparing our specimens and boxed and shipped them. They included eight skins and three heads of buffalo, and skins and skeletons of two lynxes, several coyotes, wolves and jack-rabbits, and a few birds. We settled with Clarkson for $\$ 50$, which sum covered our transportation and board for a week, and his promise to get for us three more skins of buffalo - two cows and a yearling bull, which were still lacking to complete our series.

We left Fort Hays for the East at 3 P. M. on January 12, and reached Cambridge on the $22 \mathrm{~d}$, stopping by the way at my old home in Springfield for a couple of days to visit the home folks, well satisfied with the results of our nine months' work in the field. We had collected and sent to Cambridge 200 skins, 60 skeletons and 240 additional skulls of mammals (mostly large species); 1500 bird skins, over 100 birds in alcohol, and a large number of nests and eggs; a considerable number of fishes, both fossil and recent, and a few mollusks, and many insects and crustaceans.

The following year I remained at the Cambridge Museum, cataloguing and labeling the rapidly increasing collections of birds and mammals.

\section{Yellowstone Expedition (1873).}

In May, 1873, Professor Baird, Assistant Secretary of the Smithsonian Institution, saw an opportunity to advance our knowledge of the natural history of a then lit tle known portion of the West through utilizing opportunities afforded by the large military expedition the War Department was to provide as an escort for the railroad surveyors who were to locate the Northern Pacific Railroad westward from Bismark. A number of prominent specialists were invited to coöperate in the natural history work, some of whom accepted but later found it impracticable to join the expedition. I was invited to take charge of the work in vertebrate zoölogy, and the authorities of the Museum of Comparative Zoölogy kindly granted me leave of absence to accompany the expedition, the Museum to have, a share of the duplicates obtained. The large scientific staff contemplated at the outset dwindled to a few persons, mostly with little or no experience in scientific field work, so that I was installed as chief of the party. I secured the services of Mr. C. W. Bennett, who accompanied me on my 1871 expedition, as my personal assistant. The other members of the party were a geologist, a photographer, and an artist, the latter being Mr. Konopicky of the Museum of Comparative Zoölogy. The photographer's wagon unfortunately did not arrive until the expedition had reached the Yellowstone, and he was accordingly greatly handicapped in his work. 
Mr. Bennett and I left Boston for Bismark, on the Upper Missouri, May 27, via New York, Chicago, St. Paul, Duluth and Fargo, the other members of our party joining us at New York. Passenger trains were then running over the Northern Pacific only as far as Fargo, North Dakota. Construction trains were in use beyond this point, running "on orders" at irregular and uncertain intervals. On reaching the 17 th siding, some twelve miles or more east of Bismark, we had orders to wait over till the next day for a train, or return to the 16th siding, signifying at least a day's delay. The terrain here was a wet grassy prairie, the home of myriads of mosquitoes; the shelter for the night was a box car, without seats, blankets, food, or even potable water. It seemed better to complete the journey on foot, and with two of my party and a sergeant from Fort Lincoln, with the mail for Forts Lincoln, Rice and Buford, as guide, we reached Bismark at midnight. The distance from Fargo to Bismark is 200 miles, which required nearly three days to make.

Reported the next day at Fort Lincoln, opposite Bismark, and made arrangements for transportation to Fort Rice, some twenty miles south of Fort Lincoln, and the rendezvous of the Yellowstone Expedition, where we arrived on the 8th of June. Here our party was most cordially welcomed by Gen. D. S. Stanley, commander of the Expedition, who assured us of every assistance possible in our work. Captain H. M. Lazelle, Company H, Sth Infantry, U. S. A., an officer greatly interested in several lines of scientific research, was detailed to take charge of the Scientific Corps, which was assigned to the Headquarters Division of the Expedition. In due time we were provided with the necessary equipment, comprising two (later five) six-mule baggage wagons, five tents, five saddle horses, and a detail of a sergeant and three soldiers to look after our comfort and belongings, one of them serving as cook.

The previous year the survey of the Northern Pacific Railroad route was seriously impeded in the Yellowstone region by hostile Indians. Hence a heavy military escort was this year provided for the protection of the engineer corps. The present escort comprised 1400 troops and 400 civilian employees, accompanied by a train of 300 wagons, each drawn by six mules, and 1200 beeves on the foot to furnish fresh beef en route. The escort comprised the famous Seventh Cavalry, with Gen. George A. Custer in command, and parts of the Eighth and Twenty-second Infantry, and a company of Indian scouts.

The military escort broke camp at Fort Rice on June 20, following the engineers who had taken the field some ten days before. Our course was nearly due west, and the first objective point was the Great Bend of Heart River; a later landmark was the crossing of Big Muddy Creek, where we 
were detained several days by heavy rains and high water. The Big Muddy was finally crossed on a pontoon bridge, constructed of wagon bodies filled with empty water casks. It required the greater part of two days to make the crossing after the construction of the bridge. We reached the Little Missouri July 11, via the Bad Lands and Davis Creek. The descent of the latter was a tedious day's march of twelve hours, to gain the same number of miles on our course. The stream was tortuous and the valley narrow, so that it was necessary to build ten corduroy bridges in a distance of eight miles. The infantry was deployed in single file in the bluffs on each side of the creek, to prevent a surprise attack by Indians. The ford of the Little Missouri was over a treacherous bottom, and before attempting it with the wagon train it was found necessary to consolidate the quicksands by treading with the cavalry and the herd of beeves. It was also necessary for the pioneers to construct a. roadway up the gorge on the west side in order to reach the plateau on the western side of the river.

The Yellowstone River was reached July 15, and the crossing made a few days later by means of the steamboat 'Josephine,' which met us here for the purpose of ferrying the expedition across. We remained in camp near this point for two weeks, waiting for the engineers to connect their preliminary line with their work of the previous year. A stockade was built here and named Camp Thorne, at which a large quantity of supplies was left, with a strong guard of troops, including two squadrons of cavalry and two companies of infantry. The site of Camp Thorne is now the town of Glendive. The distance from Fort Rice to Camp Thorne was 310 miles.

On July 28 we began our march up the west side of the Yellowstone. Owing to the bad lands bordering the river our line of travel was some distance to the westward, and very devious, it being necessary at times to make long detours in order to get around deep ravines, a long, hard day's march of ten or twelve hours resulting in some instances in a gain of not more than two or three miles on our course. We passed the mouth of Powder River July 30, the mouth of Tongue River August 4, the mouth of the Rosebud August 7, the mouth of the Big Horn August 12, reaching Pompey's Pillar about 8 A. M. August 15, 190 miles above Camp Thorne. This was the end of our reconnaissance on the Yellowstone, the line above Pompey's Pillar having been surveyed the previous year. On the 17 th of August we turned west toward the Musselshell River, which we struck at a point 50 miles northwest from Pompey's Pillar on the 19th. This point marked the end of the outward journey.

The next day we crossed to the left bank of the Musselshell and followed down this river, to the Big Bend of the Musselshell, which we reached 
August 27. We then struck across to the Yellowstone along the divide between Big Porcupine and Little Porcupine Creeks, reaching the Yellowstone River at the mouth of the Little Porcupine, a little above the mouth of Tongue River. Here we struck our outward trail, which we retraced to Camp Thorne, where we arrived September 7, and later, over the same trail proceeded to Fort Rice, our starting-point.

The daily routine of the march was usually as follows: Reveille at 3 A. M.; breakfast at 3.30 ; tents struck at 5 ; marching at 5.30 ; with variations to earlier or later according to special exigencies. The head of the column usually made camp at from 12.30 to 3 P. M.; when delayed by bridging streams or road-making, camping was delayed till 4.30 or later once till 6.40 and once till 7.30, after a day's march of ten, twelve, or even fourteen hours. The daily distance ranged from eight to twenty miles, according to the amount of delay incident to bad roads.

Field observations and collecting were usually restricted to the line of march, and the preparation of specimens to the daylight hours in camp. The weeks spent in camp at Fort Rice and Camp Thorne, and the delays at the crossing of the Big Muddy, the Little Missouri, and at a few other points, were utilized to the utmost by Mr. Bennett and myself for the increase of our collections. But parts of the journey were less favorable, owing to Indian trouble. Indians were first seen watching us from neighboring bluffs near the mouth of Powder River; they soon became bolder and were seen daily, when orders were given forbidding straying from the line of march, or the use of firearms without permission from the commanding officer. This compelled us to abandon bird collecting and side excursions for several weeks. The first attack upon the Expedition by the Indians was an attempt by them to ambush the advance guard of cavalry, while resting at midday some miles in advance of the main column, about twenty miles above Tongue River. Here General Custer, with seventy men, had a four hour battle with about 300 Indians on August 3, finally charging and dispersing them. But while the battle was in progress a part of the hostile band, hovering along the left flank of our main command, succeeded in killing several of our stragglers, including the veterinary surgeon, the sutler, and a cavalryman. During the fight General Custer had one private wounded and several horses killed and others wounded. The extent of the casualties of the Indians was not ascertained, but at least two were killed and several wounded. Two days later an Indian alarm caused General Stanley to halt and park the train, in preparation for an attack, but the precaution proved to have been unnecessary. Indians were seen, however, in the bluffs on the east bank of the river, and a few shots were fired at them from our six-pounders, which effectively dispersed them. 
On the 8th General Custer received orders to advance and chastise the Indians, whose hastily abandoned camps we had been passing for several days, as village after village joined the main band. He set out at 8 P. M., with 450 cavalrymen and our Indian scouts, and by a forced march overtook them about daylight on the morning of the 11th near Pompey's Pillar. The Indians were on the east bank of the river, but at once proceeded to cross and, 500 strong, opened an attack upon him from all sides. The fighting for a time was very sharp, but finally the cavalry were ordered to charge, and the Indians soon scattered in every direction. Custer had three men killed, including his orderly, and Lieut. Brayden was severely wounded in the thigh. For the next twelve hours our camp presented a decidedly warlike aspect, with our battery mounted for action and five companies of the $22 \mathrm{~d}$ Infantry doing picket duty. An attack seemed probable, but our foes evidently decided we were too well prepared, and slowly retired.

These incidents gave proof that our heavy military escort was not a needless demonstration. It was only three years later, and about sixty miles south of Pompey's Pillar, on the Little Big Horn, that General Custer and his whole command were massacred in a fight with this same band of Sioux Indians.

The opportunities for natural history collecting and field research on this expedition were far from ideal, but we did not return empty handed nor without well-filled notebooks. Very little of the large area traversed had previously been visited by a naturalist, and was still unrepresented by specimens in the National Museum. Much valuable information was gathered respecting the general character of the country and its biology, a portion of which was promptly published. ${ }^{1}$ Besides the birds, their nests and eggs, and mammals, small collections of reptiles, fishes, insects and plants were made, and also of invertebrate fossils, which were everywhere scarce. The badlands were searched at every opportunity for vertebrate remains, but always, to our great disappointment, in vain. Mr. Konopicky, the artist, made colored drawings from life of the few fishes obtained, and many excellent sketches of geological exposures and striking topographic features in the bad lands. The photographer also secured many characteristic views of the country traversed. To me it was an experience of great value from the naturalist's point of view, and one I have never ceased to recall with much pleasure for its personal associations and its dash of military flavor.

${ }_{1} C f$. Notes on the Natural History of portions of Dakota and Montana Territories, being the substance of a report to the Secretary of War on the collections made by the North Pacific Railroad Expedition of 1873, Gen. D. S. Stanley, Commander. By J. A. Allen, Naturalist of the Expedition. Proc. Boston Society of Natural History, Vol. XVII, pp. 33-91, June, 1874. Also separately, repaged. 
Special Collaborator, U. S. Geological and Geographical Survey of the Territories (18\%6-1882).

From 1874 to 1882 I gave much the larger part of my time to original research, the results of which appeared in numerous minor papers and in several monographs. The first of the latter was 'The American Bisons, Living and Extinct,' published in 1876, under the joint auspices of the Museum of Comparative Zoölogy and the Geological Survey of Kentucky (N. S. Shaler, Geologist-in-Charge). In 1876, with the approval of the director of the Agassiz Museum, I divided my time between this institution and the United States Geological and Geographical Survey, of which for the following six years I was a "special collaborator." At the end of this period the United States Geological Survey was reorganized and the scope of its work greatly restricted. Also my health became so seriously impaired that I was obliged to suspend almost entirely my research work for a considerable period (as explained later in this narrative).

My work for the Geological Survey comprised a number of minor papers published in the 'Bulletin' of the Survey and monographs of various families of North American rodents, in coöperation with the late Dr. Elliott Coues, published in 1877 as 'Monographs of North American Rodentia,' forming volume XI of the 'Memoirs' of the Survey. In 1880 was published my 'History of North American Pinnipeds, a Monograph of the Walruses, Sea-Lions, Sea-Bears and Seals of North America,' as No. 12 of the 'Miscellaneous Publications' of the Survey (8vo, pp. xvi +785 , 60 text figures). This was to have been followed by a volume of the 'Memoir' series on the North American species of the mammalian orders Cete and Sirenia. To this undertaking I had devoted about three years of intense application, and when overtaken by illness had written a large part of the text, and most of the plates had been lithographed. The only parts ever published were a portion (about one-third) of the bibliography, ${ }^{1}$ and the account (with reduced half-tone copies of the plates) of the Atlantic Right Whale, ${ }^{2}$ more than a quarter of a century after it was written. The printing of the bibliography was left uncompleted in consequence of the inability of the author to revise the proofsheets.

A serious attack of pleurisy interrupted my work in December, 1881.

${ }_{1}^{1}$ Preliminary List of Works and Papers relating to the Mammalian Orders Cete and Sirenia. Bull. U. S. Geol., and Geogr. Survey, VI, pp. 399-562, August 30, 1882 (1013 titles, carrying the subject from the year 1495 to the end of the year 1840).

2 The North American Right Whale and its Allies. Bull. Amer. Mus. Nat. Hist., XXIV, pp. 277329, pll. xix-xxiv, April 8, 1908. As here published the article is changed only by the addition of new matter to bring the subject down to the date of publication. 
In March, 1882, my physicians were so dissatisfied with my condition that they strongly urged a change of climate, and I was sent to Colorado Springs, Colorado. I went with the fullest confidence that the change of scene and air would soon completely restore my strength, and accordingly took with me a collecting outfit for ornithological field work. My good friend William Brewster, of Cambridge, joined me in a few weeks. I did not regain strength, however, and found myself quite exhausted by a half mile walk.

During the six weeks Mr. Brewster remained with me, we made many collecting trips, by carriage, to the adjacent cañons, forming a considerable collection of bird skins and acquiring much greatly valued information regarding the spring migration of birds at Colorado Springs. When he returned, two months later, to the East I was in worse condition than when I left home, and was compelled to spend the summer at a neighboring ranch in the foothills of the Rockies, thoroughly mystified at my lack of recuperative power, for the organic trouble that led to my being sent to Colorado had quite disappeared.

On returning to Cambridge in September I learned that my invalidism was due to nervous breakdown. Recovery was exceedingly slow; after a few months I regained strength for part time work at the Museum, and for a small amount of literary work, slowly increasing it, month by month, but for years afterward my physical condition was a serious handicap.

Early in 1885, the financial resources of the Cambridge Museum became much reduced, leading to the discharge of several of the assistants and the prospective dismissal of others, including myself. Through the kindness of Mr. Alexander Agassiz, three alternatives were open to me to remain at the Museum at the risk of its being soon closed; to accept a position open to me on the United States Geological Survey; or to accept a curatorship offered me by the American Museum of Natural History in New York. For family reasons (I had a motherless three-year-old boy whom it was necessary to leave with friends in Massachusetts), field work with the Geological Survey did not appeal to me, and led to my acceptance of the New York curatorship, which I have ever since felt was a wise decision.

\section{Curator at American Museum of Natural History (since 1885).}

On May 1, 1885, I entered upon my duties as curator of the 'Department of Ornithology and Mammalogy' at the American Museum of Natural History in New York. The collection of mammals then consisted of about 1000 mounted skins and 300 mounted skeletons, all on exhibition in the 
exhibition halls. There was not even a nucleus of a study collection. The collection of birds numbered about 10,000 mounted skins and several hundred mounted skeletons, all on exhibition, and about 3000 unmounted skins, forming the beginning of a study collection.

The exhibition collections were rich and varied, the specimens having been selected with excellent discrimination, mainly by the late Dr. D. G. Elliot, and included the famous Maximilian collection of mammals and birds. The exhibition collections of this department thus compared favorably with the best in this country. The North American collection of birds was essentially complete, nearly every procurable species being represented, and the specimens were all correctly determined and neatly labeled. ${ }^{1}$ But no part of either collection had been catalogued, except the European birds, which had recently been carefully registered by Dr. Edgar A. Mearns. In the case of the exotic species, of both mammals and birds, the labels bore the names under which they were originally purchased, and hence, while in most cases correctly identified, the technical nomenclature was antiquated.

The first task was therefore to catalogue the collections, thus securing a permanent record of their history. ${ }^{2}$ Fortunately, the original labels had in most cases been preserved by pasting or tacking them to the bottom of the stands. The next step was to renew the labels, in a uniform style, giving the currently accepted technical names of the specimens, with their localities, in conspicuous type.

At the end of the first year the mammals had been catalogued and relabeled. At the end of the third year most of the birds had been catalogued and provided in large part with new labels.

In the curator's first annual report, ${ }^{3}$ on the condition and extent of the collections, the importance of fine exhibition collections was not only fully recognized, but the formation of adequate study collections, to serve as the basis for scientific research, was strenuously insisted upon in order to bring the department to a proper standard of efficiency. As often as opportunity arose for securing such material, urgent appeals were made to the

1 The determination was made by Robert Ridgway of the U. S. National Museum shortly before the collection came under my care.

${ }_{2}$ "The museum assistant in charge of a special department must naturally, if the purpose for which large collections are brought together is carried out, spend the greater part of his time in preparing them for the specialist who is at some future time to avail himself of the treasures brought together for his benefit. There is, therefore, the same danger that an eminent specialist, after his appointment to the curatorship of a great museum, will find his museum duties so arduous as to prevent him, as his colleague in the professional chair has been prevented, by official work, from doing original work."-A. Agassiz, in the Ann. Report of the Curator of the Museum of Comparative Zoölogy at Harvard College for $1883-84$, p. 7.

${ }^{3}$ Annual Report of the Trustees for the year 1885 (1886), pp. 9-12. 
President for their purchase,- for the first two years usually without avail, owing to the lack of funds. ${ }^{1}$

The year 1887, however, proved to be epochal in the history of the department, not only through the addition of scientific material but in other lines of development. It was in this year that the Trustees purchased the George N. Lawrence collection of birds, a strictly research collection of immense historic importance, numbering some 12,000 specimens of (mainly) tropical American birds; and also the Herbert H. Smith collection of 4000 birds from southern Brazil. The D. G. Elliot collection of 2000 humming birds (including many types) was presented by $\mathrm{Mr}$. Elliot, and a collection of about 2250 Arizona birds was presented by Dr. Edgar A. Mearns, U. S. A. Further accession, comprising some 500 North American birds, were also added, partly by purchase and partly through the Elliot-Richardson Expedition to Montana (noteworthy as the first Museum expedition from this department), making the grand total of 21,000 birds added in this notable year, besides a large number of nests and eggs and some osteological material. The previous year a taxidermist, Mr. Jenness Richardson, had been added to the personnel of the department, through which means 18 bird groups were added to the exhibition collection, these forming the beginning of the Museum's magnificent series of 'Habitat Groups.'

During this year the efficiency of the department was further greatly enhanced by the purchase of the D. G. Elliot ornithological library, consisting of about 1000 carefully selected volumes, thus providing the $\mathrm{Mu}$ seum with an ornithological library surpassed by few similar libraries in this country. A large number of moth-proof tin cans were also provided for the safe storage of the rapidly increasing research collections.

The reception and care of these large accessions naturally checked progress in cataloging and labeling the exhibition collections, but the bird collection as a whole had suddenly been transformed from merely a show collection to one of impressive scientific importance.

Thus far the curator had had to depend upon his own efforts in cataloging, labeling, and caring for the collections, except for a little aid now and then from interested volunteer assistants; but in 1888, Mr. Frank M. Chap-

${ }^{1}$ From the Treasurer's Report for the year 1885, it appears that the contribution by the City toward maintenance was $\$ 15,000$, and that the income from invested funds was $\$ 300$. The rest of the $\$ 30,509$ expended for running expenses was met by personal contributions of the Trustees. The additional \$6,054 expended for collections and for books for the library came also from private sources.

It is of interest to compare, in this connection, the income and expenditures in 1915 with those of 1885, as indicative of the growth of the Museum in resources during the thirty-year interval. The financial statement for 1915, as given in the Forty-seventh Annual Report of the Trustees, shows the contribution from the City to have been $\$ 200,000$, leaving a deficit of $\$ 38,500$ to be met by personal contributions of the Trustees. The net receipts from endowment are given as $\$ 265,275.16$. 
man was secured as a permanent assistant, to whom twenty years later (in 1907) was assigned the curatorship of ornithology. He proved from the first an enthusiastic and efficient helper, at all times in fullest sympathy with the policies and work of the department. His various expeditions to Florida, Trinidad, Cuba, and Mexico in the earlier years of his connection with the Museum added important accessions to the research collections of mammals and birds, and later he took in hand the construction of the Habitat Groups of birds, which soon became an impressive feature of the Museum exhibits. This has been followed in recent years by his well known series of expeditions to South America, in the interests of this department.

In 1887 , on the death of Dr. J. B. Holder, who for many years had been curator of the Department of Invertebrate Zoölogy, Fishes and Reptiles, this department was also placed in my charge, ${ }^{1}$ and the collections of fishes and reptiles remained in my care till 1901.

Following the bounteous year 1887, were a number of lean years, as regards accessions to the collections; there was, however, a slow but steady increase of material from both North and South America, and in later years also important additions from Asia and Africa. These accessions afforded not only material for exhibition but for scientific research, the results of which were published in the Museum 'Bulletin.' With the gradual increase of the collections the scientific staff of the Department also increased, from a single assistant in 1888 to six assistants in 1915, besides stenographic and other non-staff office assistants and four field assistants.

As previously noted, Assistant Curator Chapman was placed in charge of the ornithological division of the department in 1907, with W. DeW. Miller as assistant; Roy C. Andrews became assistant in the mammalogical division in 1908, and assistant curator in 1911; H. E. Anthony, became

${ }^{1}$ In the list of Officers and Committees in the Annual Report for 1888, the entry for my department reads: "Prof. J. A. Allen, Curator of the Department of Ornithology, Mammalogy, Fishes and Reptiles. Also temporarily in charge of the Department of Invertebrate Zoölogy." In 1890 the Department of Invertebrate Zoölogy was transferred to the Department of Geology, Mineralogy and Conchology (Prof. R. P. Whitfield, curator), and the name of my department changed to "Department of Mammalogy, Ornithology, Herpetology, and Ichthyology." In 1898 it was renamed "Department of Vertebrate Zoölogy," and this was its official designation till 1901, when Fishes and Reptiles were assigned elsewhere and it became "Department of Mammalogy and Ornithology," the designation it has since retained.

There having been, during these years, no available exhibition space for the fishes and reptiles, I was responsible merely for their safe storage. I catalogued, however, the accessions of reptiles and batrachians, in which classes $I$ had formerly taken much interest, and of which for a time $I$ was curator at the Boston Society of Natural History.

A department of taxidermy was established, as stated above, early in 1886, and, with a chief taxidermist and a staff of several assistants, remained an adjunct of the Department of Mammals and Birds till 1903, when it was separated as a distinct department and broadened to cover a much wider field than mammals and birds. 
assistant in the same division in 1914. In 1915 Herbert Lang and James P. Chapin, on their return from the American Museum Congo Expedition, were made, respectively, assistants in mammalogy and ornithology.

Thus the curator was gradually relieved of much routine work and able to devote his time mainly to research and to the editorial supervision of the Museum 'Bulletin' and the zoölogical portion of the 'Memoirs.'

While these pages are not intended to comprise a detailed history of the department, it seems desirable to mention here some of the larger increments of the collection, on account of their bearing upon my later scientific work. One of the primary duties of a curator and his scientific staff is the identification of accessions and the prompt publication of the results of their elaboration, in the interest not only of science but of the institution with which they are connected. This obligation gives direction to their scientific activities, forcing them from general to more special lines. In this way their researches are in a measure restricted within certain boundaries.

As already noted, in 1885 there was not even the beginning of a research collection in mammalogy; in 1915 the unmounted mammals exceeded 40,000 specimens, and included a fair amount of osteological material and spirit specimens in addition to skins and skulls; while the old mounted specimens had been supplemented, and to a large extent superseded, by elaborate group exhibits, illustrating the life histories of many prominent types of North American and exotic mammals. During recent years this work and the installation of a synoptic mammal collection has been under the direct.supervision of Director Lucas and Assistant Curator Andrews.

The bird collection in 1885 included a small number of skins, mostly North American, in addition to the 10,000 mounted specimens on exhibition; in 1915 it comprised not only the most extensive and elaborate series of 'Habitat Groups' in any museum in the world, but more than 130,000 study skins. Further available as research material was the collection of Dr. Jonathan Dwight, of chiefly North American birds, numbering 45,000 specimens; Dr. L. C. Sanford's collection of North American water birds, numbering about 8000 specimens; and the Brewster-Sanford collection of about 6000 specimens, mostly seabirds in large series from the South Atlantic and South Pacific oceans and the southern coasts of South America. Thus the American Museum in 1915 contained a total of about 190,000 birds available for scientific research, exclusive of mounted birds and groups. Collectively they doubtless formed the largest and by far the most valuable collection of American birds yet assembled in any single museum.

The first notable accessions of birds were received, as already related, in 1887, and comprised two important authoritative and historic collections, the Lawrence collection of American birds (largely from tropical America 
and containing nearly all of Lawrence's types), and the Elliot collection of Hummingbirds, at that time one of the largest and most authoritative collections in the world of this numerous and most interesting suborder of birds. In the same year were also received a notable collection of birds from Arizona for the North American study series, and our first freshly collected and wholly unworked collection of exotic birds, the Herbert Smith collection of some 4000 specimens from the Province of Matto Grosso, Brazil. This became the basis of a series of papers by the curator published in the Museum 'Bulletin' in 1889-1892. In 1889 small collections of birds were received from Ecuador and Bolivia, aggregating about 600 specimens (200 species), which formed also the basis of papers in the 'Bulletin.'

During the years 1890, 1891, 1892, important accessions of mammals and birds were received through purchases of small collections from Mexico and Central America, and collections obtained through Museum expeditions to Florida, Texas, Colorado, and Washington, upon which reports were published in the 'Bulletin,' by the curator and the assistant curator. In 1893, and again in 1894, Mr. Chapman made collecting trips to the Island of Trinidad, B. W. I., resulting in the addition of 550 mammals and about 690 birds, which formed the basis of extended papers on the mammal and bird faunas of the island.

Among later collections may be mentioned the Streator collection of birds and mammals made in British Columbia in 1899; collections of birds and mammals made in Alaska and northern British Columbia by the A. J. Stone expeditions in 1897-1903; the H. H. Smith collections of birds and mammals from the Santa Marta region of Colombia, received in 1898-1901; the Peary collections of birds and mammals from Greenland and Ellsmere Land (1898-1909); the collections of Siberian birds and mammals made by N. G. Buxton on the Jesup North Pacific Expedition in 1901; the Batty collections of birds and mammals from Chiriqui and Mexico received in 1901-1906; the Nicaragua collections of birds and mammals made by W. B. Richardson in 1907-1908; the E. T. Seton collection of mammals from the Athabasca-Mackenzie region of Canada, 1908; the Tjäder East African collection of mammals, 1907; the Rainsford collection of East African mammals in 1913; the Congo collections of birds and mammals, each numbering some 6000 specimens, made by Herbert Lang and James P. Chapin, received in 1915; and the constant inflow of birds and mammals from South America, from 1911 to date, through expeditions directed by Curator Chapman and collected mainly by Leo E. Miller, W. B. Richardson, and George K. Cherrie; and the birds and mammals collected by Cherrie and Miller on the Roosevelt Brazilian Expedition; also birds and mammals collected by H. E. Anthony in Panama, and in Oregon and Washington.

The Asiatic material received, in addition to the Buxton Siberian col- 
lection already mentioned, has been mainly collections of mammals from the Island of Hainan, China, received by purchase, 1906-1908, and a few small lots of mammals received from western and northern China (by purchase); and small collections of birds and mammals collected in the Dutch East Indies by Roy C. Andrews in 1909 and in Korea in 1912. Especially should also be mentioned the important collection of cetacean material collected by Mr. Andrews in the North Pacific in 1910-1912.

This material has all been carefully studied and reported upon in the 'Bulletin' and 'Memoirs' of the American Museum, except the recently received mammals and birds of the Congo Expedition, and some of the South American collections of birds, the Cetacean material having been the basis of monographs by Mr. Andrews, while Mr. Anthony has published on the mammals collected by him in Panama and Oregon. The other mammal collection have all been reported upon in numerous papers by the writer, including a memoir on Muskoxen, recent and extinct (1913), and a revision of the South American Sciuridæ (1915). My last faunal papers on birds were reports on the Smith collection from Santa Marta, Colombia (1900-1904) and the Buxton collection from Siberia (1905). Two papers on the types of the North American genera of birds (1907) are also among my later papers on birds.

The collections of birds received prior to 1905 have been the basis of several faunal papers by Curator Chapman and Assistant Curator W. DeW. Miller. Chapman has published important preliminary papers on the recently received South American collections of birds, describing many new forms, and has now in press a report on the birds of Colombia, which forms Volume XXXVI of the American Museum 'Bulletin.' It is thus a pleasure to record that the recent field activities of my department of the Museum, so extensive and so varied, have been adequately supplemented by laboratory research and prompt publication of results.

\section{Affiliations with the American Ornithologists' Union and other Scientific Societies (since 1883).}

As regards general activities, my interests have been confined within narrow limits, partly from an inborn shrinking from functions that necessitate appearance in public positions and partly through lack of the physical endurance to meet such demands. The exception has been my connection with the American Ornithologists' Union, the founding of which was due in part to my instigation, ${ }^{1}$ and with whose activities I became from the first

1 The call for the meeting of ornithologists which led to its organization was issued by Elliott Coues, William Brewster and the writer, in 1883. 
intimately associated. Although unable to attend the meeting of ornithologists at which the Union was founded it happened that I was selected as its first president, and, contrary to my expressed wish, was annually reëlected for the following six years. This embraced of course the formative period of the society's history, when its work was planned and carried forward with the energy and enthusiasm that so strongly marked its early activities. Committees were appointed at its first meeting to take in hand various important subjects, as the migration and geographic distribution of North American birds, which investigation was prosecuted so successfully that in a few years it outgrew the financial resources of the society and led to the establishing of a Division of the United States Department of Agriculture to carry on the work, which ultimately became the present Bureau of Biological Survey, for many years under the direction of C. Hart Merriam, the chairman of this committee of the American Ornithologists' Union.

Another important committee was at the same time established to prepare a standard Check-List of North American birds, to displace the discordant check-lists then in vogue, with of course undesirable results. To accomplish this it was found necessary at the outset to have as the basis of the list a consistent and carefully prepared code of rules of nomenclature in place of then existing inharmonious codes and go-as-you-please methods of nomenclature. This led to intense research on the part of several members of the committee, and eventually to the adoption and publication of a new code, departing widely in some important respects from any of its predecessors. This A. O. U. Code later became the basis of the International Code of Zoölogical Nomenclature, framed on essentially the same lines and departing from it in no essential respect, except in point of brevity, through omission of adequate illustrations of the rules, and thereby rendering necessary the issuance of official 'Opinions' to clear up obscure points. A draft of the A. O. U. Code was made by two members of its Nomenclature Committee, to serve as a working basis for the Committee, which after long and careful consideration by the full Committee was adopted essentially as written, not only as to form and phraseology but also (with the exception of the addition of a single provision, since abandoned) as to its rulings. ${ }^{1}$

The work of the A. O. U. Nomenclature Committee resulted not only in a new check-list of North American birds, standardizing their nomenclature, but also a new and elaborate Code of Zoölogical Nomenclature,

${ }_{1}$ It may be pardonable in this connection to state that the preliminary draft was written in part by Elliott Coues (mainly the part comprising the 'General Principles') and the rest, including the historical part of the 'Introduction' and most of the 'Canons' and their explanatory 'remarks', by the author of these 'Notes.' 
which has had vast influence in standardizing the rules of nomenclature the world over. ${ }^{1}$

Still another important A. O. U. Committee had its inception at the first meeting of the Union in 1883, namely, a Committee on the Protection of North American Birds, which carried on the work of bird protection for many years with great energy and very important results. From it originated later the so-called Audubon Societies movement, from which, through the special efforts of one of its enthusiastic members, William Dutcher, was developed the present powerful organization known as the National Association of Audubon Societies. From this committee also emanated the A. O. U. "Model Bird Law," which has been enacted by most of the States in this country and the Provinces of Canada, in the essential phraseology of the committee's draft. In this work I shared actively, furnishing in 1886 most of the matter for the 'Bulletins' of the committee, issued first in 'Science' and afterwards separately reprinted in large editions.

For many years my interest in the activities and welfare of the American Ornithologists' Union was absorbing. For seven years I was its president, for twenty-seven years the editor of its journal 'The Auk' and its other publications; and a member of its Committee on the Classification and Nomenclature of North American Birds from 1883 to date. For twentyeight years I maintained an unbroken record of attendance at its annual congresses and council meetings.

Before leaving Cambridge I had begun to take a more or less active part in the work of the Boston Society of Natural History, having served as acting secretary and editor of its publications for a number of months, to fill an interim, and for a number of years had been a member of its Council.

On my arrival in New York I was warmly welcomed by the New York Academy of Sciences, and almost immediately given a place on its Council, and later for several years was a Vice-President; but I failed to identify myself heartily with its interests, due in part to limitations imposed by impaired health.

My affiliation with the Linnæan Society of New York was more intimate, and the office of president for a number of years never proved very strenuous, as the attendance was usually small and the meetings more or less informal and semisocial.

${ }_{1}$ A revised edition of the A. O. U. Code was published in 1910 , in which the article adopted by the International Congress in 1909, newly defining the method for the determination of types of genera, was substituted for the corresponding matter in the original A. O. U. Code.

The editing and carrying through the press of the three editions of the Check-List and of fifteen of its sixteen supplements, and also the original and the revised editions of the Code, was a labor of love for the author of these 'Notes.'

Elliott Coues was chairman of the Nomenclature Committee from its inception in 1883 till his death in 1899. He was succeeded by C. Hart Merriam, who held this position till 1904, when he was succeeded by the writer, who resigned in 1912 . 


\section{General Considerations and Home Life (since 1874).}

As a fact of possibly some psychological interest I may here briefly revert to a handicap with which probably few called to public functions have had, at least in equal dégree, to contend. From early boyhood I was painfully embarrassed in the presence of strangers. Later in life attempts to present papers verbally before scientific societies were always unsatisfactory and often failures, not from lack of familiarity with the details of the subject but from embarrassment. The same timidity prohibited my seriously considering teaching as a possible means of raising funds to aid in meeting the expenses of an education, or of giving public lectures for the same purpose, as many of my associates at the Agassiz Museum were doing, with both pleasure and profit. The ordeal of an examination for a degree at the Lawrence Scientific School at Harvard was sufficient to banish all aspiration for such honors. This in part, perhaps, led to a feeling of disrespect for this sort of a label, and to the belief that any worthy accomplishment would, sooner or later, receive due recognition. My wants were simple and inexpensive; all I aspired to was opportunity for scientific research, believing that diligence, singleness of purpose, and honest work would bring its own reward. I was content to follow my own lines of dominating interest to such limit as the circumstances of earning a living would permit. I never had any desire for money as such, nor any interest whatever in financial projects, nor any longing for honors beyond those my colleagues in science saw fit to impose. Therefore my election, in the course of time, to all of the leading academies of science in this country, and to honorary membership in foreign societies with which my lines of study were affiliated, have always come as exceedingly pleasant surprises. The greatest surprise of all, however, was the reception of a Ph.D. from Indiana University in 1886, the first intimation of which was the receipt from its president, David Starr Jordan, of the official notification that I had been thus honored.

In looking back to the beginning, it is difficult not to contrast my early surroundings with those of the average youth of today smitten with the nature study 'craze.' As stated in the early part of these notes, I was wholly isolated from everyone having even the slightest biologic interest, with only the inspirations and opportunities afforded by the little red schoolhouse on the hill, in the fifties of the last century, in a neighborhood of small farmers to whom the raising of potatoes and grain was the chief aim of life. My studies were not only selfchosen, but were carried on in odd hours without either advice or encouragement, in contrast with the systematised training of today, from the primary school to the post graduate 
course. My first systematic guidance was received at the Agassiz Museum in 1862; to the personality and influence of the 'Great Teacher,' Louis AgAssiz, I can never adequately express my indebtedness.

I cannot close these 'Notes' without reference to the most important of the influences that have most happily and most strongly affected my career.

In 1874 it was my good fortune to have won the love of Mary Manning Cleveland, of Cambridge, Mass., daughter of the late Dr. Anthony Benezet Cleveland and Mary (Manning) Cleveland, sister of the late Professor William C. Cleveland of Cornell University and of Dr. Clement Cleveland, an eminent surgeon of New York. We were married October 6, 1874. She died April 17, 1879, leaving a son, Cleveland Allen, ten months old, now in business in New York. Never could marital affection nor mutual interest and sympathy be stronger than was our lot to enjoy. When the end came there seemed little worth while in life.

After seven years I had the equally good fortune to make the acquaintance of Susan Augusta Taft, daughter of the late Daniel and Emeline (Smith) Taft, of Cornwall-on-Hudson, N. Y. We were married April 27, 1886, and have enjoyed thirty-one years of happiness, unalloyed except by her several acute but temporary illnesses, when again the light of life seemed vanishing. My own health during this long period having been by no means strong, I owe to her deep love and sympathy, to her supreme optimism and constant watchfulness over my health, and to her inspiration, the greater part of the little I may have achieved in these last thirty years, and doubtless many years of activity beyond those I otherwise should have attained.

\section{ADDENDA.}

\section{Expeditions.}

1865. Zoölogical Assistant on the Thayer Expedition to Brazil, under Professor Louis Agassiz, April, 1865-March, 1866.

1867. Collecting Expedition to western New York, southeastern Indiana, northern Illinois, western Iowa, southern Michigan, May-October, 1867. (A private enterprise.)

1868-69. East Florida: Jacksonville, via St. Johns River, to the head of Lake George, December, 1868-April, 1869, with two volunteer assistants (Rev. Thomas Marcy and J. E. Brundage). Made under the auspices of the Museum of Comparative Zoölogy.

1871-72. Fort Leavenworth, Kansas, west to Northern Utah, May, 1871-February, 1872, with two assistants (Caleb W. Bennett and Richard Bliss, Jr., the latter 
from May to August). Made in the interest of the Museum of Comparative Zoölogy.

1873. Bismark, North Dakota, to the Yellowstone River, thence up the Yellowstone to Pompeys Pillar, north to the Musselshell River, and east to the Yellowstone and Bismark. Made under the auspices of the Smithsonian Institution, as chief of the party of Naturalists of the North Pacific Railroad Expedition of 1873, Gen. D. S. Stanley, Commander.

\section{Positions Held.}

Assistant in Ornithology and Curator of Birds and Mammals in the Museum of Comparative Zoölogy at Harvard College, 1870-1875.

Lecturer on Ornithology at Harvard College, 1871-1873.1

Curator of Reptiles, Boston Society of Natural History, 1868-1871.

Curator of Birds and Mammals, Boston Society of Natural History, 1870-1880.

Acting Secretary, Boston Society of Natural History, October, 1874-May, 1875.

Councilor, Boston Society of Natural History, 1881-1885.

Corresponding Secretary, Nuttall Ornithological Club, and Editor of its 'Bulletin,' $1876-1883$.

President of the American Ornithologists' Union, August, 1883-November, 1891. Editor of its journal 'The Auk,' and of its other publications, 1883-1912. Subcommittee (with E. Coues) to codify the rules of nomenclature for discussion by the full Committee on the Revision of the Nomenclature and Classification of North American Birds, 1883-1886. Chairman of the Committee on the Nomenclature and Classification of North American Birds, 1904-1912. Chairman of the Committee on Revision of the Code of Nomenclature, 1905-1908.

Curator of Birds and Mammals at the American Museum of Natural History, New York, since 1885. Editor of the 'Bulletin' and the zoölogical series of the 'Memoirs,' since 1889.

${ }^{1}$ A course of twelve lectures was planned but, if I remember rightly, only four or five were delivered. As they were intended to treat the subject seriously they were naturally technical rather than 'popular,' and the audience soon dwindled to a few students actually interested in the subject. While read from manuscript, they were elaborately illustrated by specimens with extemporized explanations, particularly as respects the osteology and pterylography of the subject. In my inexperience in such matters, an average attendance of half-a-dozen auditors seemed farcical, and I counted myself a failure as a lecturer and did not complete the course. On looking over the manuscript and the schedule of the course in later years I have felt chagrin that it was not completed, as the attendance was as large as should have been expected at a course so specialized in character. The following is the schedule of the course: I. The distinctive characteristics of birds in comparison with other vertebrates; birds as a modification of the vertebrate type for aërial locomotion; the osteology of birds. II. The muscular and nervous systems and the organs of sense. III. The digestive, circulatory and respiratory systems and vocal organs. IV. Reproductive organs and embryological development. V and VI. The tegumentary system, including the development of feathers, their arrangement, structure, modifications and functions. VII. Historical summary of the principal systems of classification. VIII, IX, and X. The classification of birds, with a general review of the leading groups. XI and XII. Geographical distribution of animals, with special reference to birds; geographical variation in birds.

In short, the lectures were planned to form a compendium of bird-lore, and had they been completed and published, with proper illustrations, they would have furnished in concise form a useful reference work for the bird student, the need for which was not supplied, even in part, till 1884, when Coues's 'General Ornithology' was added to the second edition of his invaluable 'Key to North American Birds.' 
One of the five incorporators of the (first) Audubon Society for the Protection of Birds, New York, 1886.

A Founder and Director of the Audubon Society of the State of New York, 1897-1912.

Vice-President New York Academy of Sciences, 1891-1894. Member of Council, 1886-1896.

President of the Linnæan Society of New York, 1890-1897.

A Founder, Director, and member of the Executive Committee of the National Association of Audubon Societies, since 1905. Second Vice-President, 1908-1912.

Member of the Commission on Zoölogical Nomenclature of the International Congress of Zoölogy, since 1910.

\section{Honors Conferred.}

Humboldt Scholarship, Lawrence Scientific School, Harvard College. 1871. Honorary Ph.D., Indiana University. 1886.

Walker Grand Prize, Boston Society of Natural History. 1903.

Medal of the Linnæan Society of New York. 1916.

\section{Honorary and Corresponding Memberships.}

Fellow of the American Academy of Arts and Sciences, Boston. 1871.

Corresponding Member of the Lyceum of Natural History, New York. 1874.

Corresponding Member Sociedad Mexicana Historia Natural, Mexico. 1874.

Fellow of the American Association for the Advancement of Science. 1875.

Member of the National Academy of Sciences, Washington. 1876.

Corresponding Member of the Davenport Academy of Sciences, Iowa. 1877.

Fellow of the American Philosophical Society, Philadelphia. 1878.

Fellow of the American Ornithologists' Union. 1883. (A Founder; President, 1883-1891.)

Honorary Member of the Nuttall Ornithological Club, Cambridge. 1886.

Life Member of the Metropolitan Museum of Art, New York. (By kindness of Morris K. Jesup.) 1887.

Fellow of the New York Academy of Sciences. 1886.

Honorary Member of the New York Zoölogical Society. 1887.

Foreign Member of the British Ornithologists' Union. 1890. Honorary Member since 1907.

Foreign Member of the Zoölogical Society of London. 1891. Honorary Fellow since 1901 .

Honorary Member of the California Academy of Sciences. 1892.

Corresponding Member of the Academy of Natural Sciences of Philadelphia. 1893.

Extraordinary and Foreign Member of the Deutsche Verein zum Schultze der Vogelwelt. 1900.

Honorary Member of the Australian Ornithologists' Union. 1904.

Charter Member of the American Association of Museums. 1905. 
Honorary Member of the Deutsche Ornithologische Gesellschaft. 1907.

Honorary Member of the Hungarian Central Bureau of Ornithology. 1909.

Honorary Member of the South African Ornithologists' Union. 1909.

Life Member of the City Library Association, Springfield, Mass. 1910.

Active or corresponding membership is or has been held in the following Societies, mostly additional to those mentioned above: Boston Society of Natural History, 1862-1887 (corresponding member since 1887); Essex Institute, Salem, Mass., 1874-1887 (corresponding member since 1887); Torrey Botanical Club, New York, 1893-1909; Linnæan Society of New York, since 1885 (President, 1890-1897); American Society of Naturalists, since 1891; Biological Society of Washington, since 1882; Washington Academy of Sciences, since 1900; American Society of Geographers, since 1905. 


\section{BIBLIOGRAPHY.}





\section{BIBLIOGRAPHY.}

This Bibliography does not include hundreds of minor reviews, particularly of ornithological papers published in the 'Bulletin' of the Nuttall Ornithological Club and 'The Auk,' ${ }^{1}$ nor many of the unsigned editorial paragraphs in the 'Notes and News' department of the same journals, all of which, unless signed, are by the editor. It does, however, include the unsigned biographical notices, which, unless otherwise indicated, are by the editor. In the case of reviews, those omitted are usually brief announcements of technical papers, noting little beyond the fact of their publication and general import, or works or papers of a more or less popular character, hardly entitled to consideration as serious contributions to science.

The titles are arranged in nine sections: (1) Mammals, about 270 titles; (2) Birds, about 965 titles; (3) Reptiles, 5 titles; (4) Zoögeography, 9 titles; (5) Evolution, 22 titles; (6) Nomenclature, 27 titles; (7) Biography, 118 titles; (8) Miscellaneous, a few titles each on botanical, geological, and other subjects; (9) Editorial Work.

In the case of papers of a mixed character, like that on 'Mammals and Winter Birds of East Florida,' where four special subjects are formally treated under the same general title, or in the case of faunal papers which include mammals and birds, and in one case also reptiles and plants, titles are repeated under each section to which they in part formally relate; beyond these few special cases titles are not repeated under the different sectional headings, although subjects additional to that indicated by the title may be incidentally discussed, as in some reviews and faunal papers.

1 Volumes I-XXVIII. My editorial connection with 'The Auk' closed with the issue for January, 1912, Volume XXXIX.

The general indexes to these two journals contain about 1400 entries under my name, of which about 1250 are indicated as reviews. Of this number less than 700 are included in this bibliography. 


\section{I.-MAMMALS.}

1869.

1. Catalogue of the Mammals of Massachusetts, with a critical revision of the species. <Bull. Mus. Comp. Zoöl., I, No. 8, pp. 143-252, Oct., 1869.

68 species, with critical and other extended annotations. The revisional comment was unfortunately based largely on the literature of the subject, in the absence of actual specimens of many of the forms considered.

1870.

2. Notes on the Mammals of Iowa. <Proc. Boston Soc. Nat. Hist., XIII, pp. 178194, Feb., 1870.

48 species, with brief field and critical notes.

3. On the Eared Seals (Otariadæ), with detailed descriptions of the North Pacific Species, by J. A. Allen. Together with an Account of the Habits of the Northern Fur Seal (Callorhinus ursinus), by Charles Bryant. <Bull. Mus. Comp. Zoöl., II, No. 1, pp. 1-108, pll. i-iii, August, 1870.

I. (1) Résumé of recent contributions to the natural history of the Otariadæ, pp. 4-19; (2) affinities, distinctive characters and synonymy, with remarks on sexual, age and individual variation, and a conspect.us of the genera and species, pp. 19-45; (3) on the North Pacific species, pp. 45-89. II. Habits of the Northern Fur Seal, etc., by Charles Bryant, with notes by J. A. Allen, pp. 89-108.

Oulophocinæ, p. 44, and Trichiphocinæ, p. 44, subfamm. nov. of Otariidæ; subsequently abandoned.

4. A Spike-horned Moose.<Amer. Nat., IV, p. 443, with 1 fig., Sept., 1870.

Captured in northern Maine, where 'spike-horns' are said to be well-known to moose hunters.

5. The Distribution of the Moose in New England. <Amer. Nat., IV, pp. 505-506, Nov., 1870.

Frequent in northern Maine, scarce in extreme northern parts of New Hampshire and Vermont, and in the Adirondacks in New York.

1871.

6. The Classification of the Eared Seals. <Amer. Nat., V, pp. 37-42, March, 1871.

Reply to criticisms by Theodore Gill of my paper on the Eared Seals (supra, No. 3), in Amer. Nat., IV, pp. 675-684, Jan. 1871.

7. The Fauna of the Prairies. <Amer. Nat., V, pp. 4-9, March, 1871.

Mammals, passim., pp. 4-6.

8. On the Mammals and Winter Birds of East Florida, with an examination of certain assumed specific characters in Birds, and a sketch of the Bird-faunæ of Eastern North America. <Bull. Mus. Comp. Zoöl., II, No. 3, pp. 161-450, pll. 4-8, April, 1871.

Annotated list of the mammals, 35 species, pp. 168-185. Trichechus manatus Linné employed as the name of the Manatee (p. 171). 
1872.

9. "'Spike-horned Muledeer."<Amer. Nat., VI, pp. 692-693, Nov., 1872.

The "Spike-horned" mule deer recorded in a previous number of the American Naturalist (July, 1872) by E. D. Cope is shown to have been a young elk.

10. Description of a Specimen of Balcenopterus musculus. <Amer. Nat., VI, pp. 473-474, August, 1872.

Review of a memoir by Thomas Dwight, Jr., on this species (Mem. Boston Soc. Nat. Hist., II, pp. 203-230, June, 1872).

11. The Habits of the Orca. <Amer. Nat., VI, pp. 474-475, August, 1872.

Review of C. M. Scammon's paper 'The Orca' (Overland Monthly, July, 1872, pp. 52-57).

12. [Geographical Variation in Mammals and Birds.]<Proc. Boston Soc. Nat. Hist., XV, pp. 156-159, Sept., 1872.

Mainly in reference to birds.

1874.

13. Laws of Geographical Variation in North American Mammals and Birds. <Amer. Nat., VIII, pp. 227-229, April, 1874.

In reference to R. Ridgway's paper (Amer. Nat., VII, pp. 548-555, Sept., 1873) on the same subject.

14. Notes on the Mammals of portions of Kansas, Colorado, Wyoming, and Utah. $<$ Bull. Essex Inst., VI, pp. 43-66, May, 1874.

Four distinct lists of mammals observed in the region named in the title, with notes o: their habits, distribution, etc. I. Mammals of Middle and Western Kansas, 28 species, with three pages on Cynomys ludovicianus, pp. 45-52. II. Mammals of Park County, Colorado, 37 species, pp. 53-58. III. Mammals of Carbon County, Wyoming, 32 species, pp. 58-61. IV. Mammals of Great Salt Lake Valley, Utah, 42 species, pp. 61-66.

15. Notes on the Natural History of portions of Dakota and Montana Territories, being the substance of a report to the Secretary of War, on the collections made by the North Pacific Railroad Expedition of 1873, Gen. D. S. Stanley, commander. <Proc. Boston Soc. Nat. Hist., XVII, pp. 33-91, June, 1874. (Also as a separate pamphlet of $61 \mathrm{pp} ., 1874$. )

Mammals, pp. 36-45 (pp. 6-13 of the reprint), 31 species; notes on habits, distribution, etc.

16. On Geographical Variation in Color among North American Squirrels; with a list of the Species and Varieties of the American Sciuridæ occurring north of Mexico. <Proc. Boston Soc. Nat. Hist., XVI, pp. 276-294, June, 1874.

Variation in color, pp. 276-286; list of species and varieties, pp. 286-294. Genera: Sciurus, Sciuropterus, Tamias, Spermophilus, Cynomys, Arclomys. Species, 25, with 19 additional varieties $=44$ forms. Vars. nov.: (1) Tamias quadriviltalus var. pallidus, p. 289; (2) Spermophilus tridecem-lineatus var. pallidus, p. 291; (3) Spermophilus parryi var. kodiacensis, p. 292.

17. Scammon's 'Marine Mammals of the Northwest Coast and American Whalefishery.' <Amer. Nat., VIII, pp. 632-635, Oct., 1874.

An appreciative review of this important work (4to). 
1875 .

18. Synop: is of the American Leporidæ. <Proc. Boston Soc. Nat. Hist., XVII, 1875, pp. 430-436.

10 species, and 5 varieties $=15$ forms.

19. The Marine Mammals of Western North America.<The Nation, No. 501, Feb. 4, 1875.

Review of Scammon's ‘Marine Mammalia' (cf. supra, No. 17).

20. Geographical Variation in Color among Squirrels. <Amer. Nat., IX, pp. 504509, Sept. 1875.

Extended abstract, with editorial comment, of No. 16, supra.

1876.

21. The North American Bison and its Extermination. <Penn Monthly, VII, No. 75, pp. 214-224, March, 1876.

A general summary of the subject.

22. Recent Memoirs on North American Mammals.<Amer. Nat., X, pp. 423-425, July, 1876.

Synoptic review of Theodore Gill's 'Synopsis of Insectivorous Mammals' (Bull. U.S. Geol. and Geogr. Surv. Terr., No. 2, May, 1875).

23. The Former Range of some New England Carnivorous Mammals. <Amer. Nat., X, pp. 708-715, Dec., 1876.

Citations of many early records, showing their former occurrence far south of their present ranges, and their great decrease in numbers as well as range.

24. "Hare and Rabbit." < Forest and Stream, VI, No. 18, p. 284, June 8, 1876.

On the significance and use of the terms.

25. A Description of a new Generic Type (Bassaricyon) of Procyonidæ from Costa Rica.<Proc. Acad. Nat. Sci. Philadelphia, 1876, pp. 20-23, pl. i, April 18, 1876.

Bassaricyon gabbi, gen. et sp. nov.

26. List of Mammals and Birds collected at Lake Titicaca, Peru. With field-notes by Samuel Garman.<Bull. Mus. Comp. Zoöl., III, No. 15, July, 1876, pp. 349-359.

Mammals, 10 species, pp. 349-352.

27. Description of some remains of an Extinct Species of Wolf and an Extinct Species of Deer from the Lead Region of the Upper Mississippi. <Amer. Journ. Sci. and Arts, 3d ser., XI, pp. 47-51, Jan., 1876.

Canis mississippiensis and Cervus whitneyi, spp. nov., p. 49.

28. Geographical Variation among North American Mammals, especially in respect to size.<Bull. U. S. Geol. Surv. Terr., II, No. 4, pp. 309-344, July 1, 1876. 
Relates exclusively to the fissiped Carnivora.

"In a general way, the correlation of size with geographical distribution may be formulated in the following propositions:

"(1) The maximum physical development of the individual is attained where the conditions of environment are most favorable to the life of the species. Species being primarily limited in their distribution by climatic conditions, their representatives living at or near either of their respective latitudinal boundaries are more or less unfavorably affected by the influences that finally limit the range of the species....

“(2) The largest species of a group (genus, subfamily, or family, as the case may be) are found where the group to which they severally belong reaches its highest development, or where it has what may be termed its center of distribution. In other words, species of a given group attain their maximum size where the conditions of existence for the group in question are the most favorable, just as the largest representatives of a species are found where the conditions are most favorable for the existence of the species.

“(3) The most 'typical' or most generalized representatives of a group are found also near its center of distribution, outlying forms being generally more or less 'aberrant' or specialized Thus the Cervidæ, though nearly cosmopolitan in their distribution, attain their greatest development, both as respects the size and the number of the species, in the temperate portions of the northern hemisphere. The tropical species of this group are the smallest of its representatives. Those of the temperate and cold temperate regions are the largest, where, too, the species are the most numerous.... The possession of large, branching, deciduous antlers forms one of the marked features of the family. These appendages attain their greatest development in the northern species, the tropical forms having them reduced almost to mere spikes, which in some species never pass beyond a rudimentary state...." (p. 310).

29. Geographical Variation among North American Mammals, especially in respect to size.<Amer. Nat., X, pp. 625-627, Oct., 1876.

Abstract of the preceding (No. 28).

30. Memoirs of the Geological Survey of Kentucky. | N. S. Shaler, director. | Vol. I, Part ii. | - The American bisons, | living and extinct. | By J. A. Allen. | With twelve plates and map. | - University press, Cambridge: | Welch, Bigelow, \& Co. | 1876. Also:

Memoirs of the Museum of Comparative Zoölogy,| at Harvard College, Cambridge, Mass. | Vol. IV, No. 10. | | The American bisons, living and extinct:|By J. A. Allen. | Published by permission of N. S. Shaler, director of the Kentucky / Geological Survey. With 12 plates and a map. | University press, Cambridge: | Welch, Bigelow, \& Co. | 1876.

$4^{\circ}$, pp. i-ix, 1-246, 1 col. map, 12 pll., 13ll., 2 woodcuts in text. Edition of 500 copies.

These two publications were simultaneous, and only differ in the titles. The following are the contents: -

Title, p. i.

Preliminary note (by N. S. Shaler), p. iii.

Introduction, pp. $\mathrm{v}$-ix.

\section{Part I.}

1. Distinctive characteristics and affinities of the bisons, pp. 1-3.

2. General historical account of the remains of extinct bisons hitherto found in North America, pp. 3-7.

3. Description of the extinct species, pp. 7-31.

4. Geographical distribution and geological position of the remains of the extinct bisons of North America, pp. 32-35.

5. Relation of the existing species of bisons to the extinct species, pp. 35-36.

6. Description of the existing species, pp. 36-70.

\section{Part II.}

1. Geographical distribution, past and present, of Bison americanus, pp. 71-191.

2. Products of the buffalo, pp. 191-201.

3. The chase, pp. 202-215.

4. Domestication of the buffalo, pp. 215-221. 
Appendix I. Additional notes on the former range and early abundance of the bison east of the Mississippi River, pp. 223-231.

Appendix II. On the age of the bison in the Ohio Valley, by N. S. Shaler, pp. 232-236.

Index, pp. 237-246.

Map, colored, to illustrate the geographical distribution, past and present, of Bison americanus, and 12 plates, each with unpaged explanatory leaf: pl. i, horncores of Bison latifrons; pl. ii, atlas of $B$. latifrons and $B$. americanus; pl. iii, teeth of $B$. antiquus and $B$. americanus; pl. iv, skull of $B$. antiquus; pll. $\mathrm{v}$ and vi, individual variation in skulls of $B$. americanus; pl. vii, skulls of $B$. americanus and $B$. bonasus, and tarsal bones of $B$. americanus and $B$. latifrons?; pl. viii, horns of $B$. americanus and $B$. antiquus; pl. ix, milk dentition of $B$. americanus; pl. $\mathrm{x}$, stages of attrition due to age in teeth of $B$. americanus; pl. ix, metacarpal bones of $B$. americanus; pl. xii, molar-premolar series in $B$. americanus and Bos taurus.

31. Recent Contributions to North American Mammalogy.<Amer. Nat., X, pp. 362-365, June, 1876. (Anonymous.)

Review of Coues's 'Synopsis of the Muridæ (Proc. Acad. Nat. Sci. Philadelphia, 1874) and his 'Some Account.... of Zapus hudsonius' (Bull. U. S. Geol. Surv. Torr., Ser. 2, No. 5, Jan., 1871.

32. Exploration of Lake Titicaca, by Alexander Agassiz and S. W. Garman. III. List of Mammals and Birds, with Field Notes by Mr. Garman.<Bull. Mus. Comp. Zoöl., III, pp. 349-359, July, 1876.

Mammals, pp. 350-353; 10 species. [Accidental duplication of No. 26, supra.]

33. The Extirpation of the larger Indigenous Mammals in the United States. $<$ Penn. Monthly, pp. 794-806, Oct., 1876.

\section{7.}

34. History of the American Bison, Bison americanus. <Ninth Ann. Rep. U. S. Geol. Surv. Terr. for the year 1875, pp. 443-587, June, 1877. Edition of 7000 copies; also separate, 1000 copies.

A republication of the original memoir (see supra, No. 30) under Dr. Coues's editorship, exclusive of the map and plates, with the following changes:-

1. The omission of the illustrations, explanatory pages, and textual references.

2. The omission of the portion relating to the extinct species, the present reprint being confined to the one existing species, beginning at page 36 of the original.

3. The incorporation of the appendices in the body of the text.

4. The addition of much new matter by the author himself.

5. Various minor modifications with the slight alteration, chiefly verbal, of context incident thereto.

6. Alteration of the title and substitution of editorial preface for the preliminary matter of the original.

"No editorial abridgment or digest of any part of the memoir was made, the portions of the memoir here reproduced being according to copy furnished by author, who added much new matter and made some little changes passim in the context. A few editorial notes, chiefly explanatory of modifications of the text, are introduced in brackets." $-E$. Coues, editor.

35. Additional note on Bassaricyon gabbi.<Proc. Acad. Nat. Sci. Philadelphia, 1877, pp. 267-268, pl. ii.

By error, a description and figure of Nasua narica.

36. Monographs of North An.erican Rodentia. By Elliott Coues and Joel Asaph Allen. = Report of the U. S. Geol. Survey of the Territories (F. V. Hayden, 
U. S. Geol.-in-Charge), Vol. XI. Washington: Govern. Printing Office, August, 1877. $4^{\circ}$, pp. i-x, 1-1091, pll. i-v.

The following by J. A. Allen: -

Monograph II. Leporidæ, pp. 265-378. Mon. III. Hystricidæ, pp. 379-398. Mon. IV. Lagomyidæ, pp. 399-414. Mon. V. Castoroididæ, pp. 415-426. Mon. VI. Castoridæ, pp. 427-454. Mon. XI. Sciuridæ, pp. 631-940. Appendix A. Synoptical List of the Fossil Rodentia of North America, pp. 943-950.

Fam. nov. Castoroididæ, p. 419; Lepus sylvaticus var. arizonæ, var. nov., p. 332; Lepus graysoni, sp. nov., p. 347; Lepus brasiliensis var. gabbi, var. nov., p. 419; Tamias asiaticus var. borealis, var. nov., p. 793.

Respecting Mon. XI, Sciuridæ, see Allen, Bull. Amer. Mus. Nat. Hist., XXXIV, p. 153, May 17, 1915 (infra, No. 259).

37. Material for Bibliography of North American Mammals. Prepared by Theodore Gill and Elliott Coues. Appendix B to Coues and Allen's 'Monographs of North American Rodentia,' pp. 951-1081, August, 1877.

"In the labor of preparing this matter for the press, which has devolved upon Dr. Coues, much assistance has been rendered by Mr. Allen, who has kindly revised the proofs, adding some titles, and making many valuable suggestions." - Gill and Coues, l. c., p. 951.

"Q.-Addenda" to the foregoing, pp. 1074-1081. "For most of the following titles, about 250, the compilers are indebted to the kind attentions of Mr. J. A. Allen. They were received during the printing of the Bibliography, but too late for insertion under their proper heads, and represent, in particular, many important palæontological papers by Leidy, Marsh and Cope."-Gill and Coues, l. c., p. 1074.

38. Northern Range of the Bison. <Amer. Nat., XI, No. 10, Oct., 1877, p. 624.

Its presence on the Peace and Hay Rivers, near Great Slave Lake, recorded on information received from E. W. Nelson.

39. American Insectivorous Mammals. <Amer. Nat., XI, No. 10, Oct., 1877, pp. 613-615. (Anonymous.)

Review of Coues's 'Precursory Notes on American Insectivorous Mammals,' etc. (Bull. U.S. Geol. Surv. Terr., III, pp. 631-653, May, 1877).

40. North American Fur-bearing Animals.<Amer. Nat., XI, No. 10, Oct., 1877, pp. 617-619. (Anonymous.)

Review of Coues's “Fur-bearing Animals," 1877.

41. Cope's Vertebrate Palæontology of New Mexico.<Amer. Nat., XI, No. 12, Dec., 1877, pp. 750-753. (Anonymous.)

Review of Vol. IV, pt. ii, of Report U. S. Geogr. Surv. West of One Hundredth Meridian.

1878.

42. The Geographical Distribution of the Mammals, considered in relation to the principal ontological regions of the earth, and the laws that govern the distribution of animal life.<Bull. U. S. Geol. and Geogr. Surv. Terr., IV, No. 2, pp. 313-377, May, 1878.

Contents: - I. Distribution of mammalian life in the Northern Hemisphere, considered in relation to laws of geographical distribution, pp. 313-329.- Historical résumé, with critical analysis of views of Sclater and Wallace.

II.-Mammalian regions of the Globe, pp. 329-373. - (1) Arctic Realm; (2) North Temperate Realm; (3) Tropical Realm; (4) South American Temperate Realm; (5) IndoAfrican Realm; (6) Australian Realm; (7) Lemuriản Realm; (8) Antarctic Realm.

The realms are divided into regions and provinces.

III.- General Summary, pp. 373-377, with diagram of realms, regions and provinces. 
43. Synonymatic list of the American Sciuri, or Arboreal Squirrels. $<$ Bull. U. S. Geol. and Geogr. Surv. Terr., IV, No. 4, pp. 877-887, 905, Dec., 1878.

Revised list of species, with nomenclatural changes from the Monograph of the Sciuridæ in Coues and Allen's 'Monographs of North American Rodentia,' 1877 (see supra, No. $36)$.

1879.

44. On the Coatis (genus Nasua Storr).<Bull. U. S. Geol. and Geogr. Surv. Terr., V, No. 2, pp. 153-174, Sept., 1879.

Monographic revision of the genus Nasua.

45. On the Species of the Genus Bassaris. <Bull. U. S. Geol. and Geogr. Surv. Terr., V, No. 3, pp. 331-340, Nov., 1879.

Monographic revision of the genus Bassaris.

1880.

46. The Fauna of Eastern Massachusetts: Forms brought in and expelled by Civilization. < Memorial History of Boston, edited by Justin Winsor, I, 1880, Chap. ii, pp. 9-16.

Relates to mammals only.

47. History of North American Pinnipeds: A Monograph of the Walruses, Sealions, Sea-bears and Seals of North America. Washington: Govern. Printing Office, $1880 .=$ U. S. Geol. and Geogr. Surv. Territories (F. V. Hayden, U. S. Geol.-in-Charge), Miscel. Publ. No. 11. $8^{\circ}$, pp. i-xvi, 1-785, 60 woodcuts.

Family Odobænidæ, pp. 5-186. Odobænus Brisson (1762) the proper generic name for the walruses, and Odobænidæ the proper name for the family - not Trichechus (auct. non Linné), nor Trichechidæ, which are, respectively, the proper names of the Manatees; ${ }^{1}$ two species of walrus established, $O$. rosmarus (Linn.) and $O$. obesus (Illiger), with figures of skulls, and full history of each species, including the nomenclature, osteology and dentition, geographical distribution, chase and commercial products.

Family Otariidæ, pp. 187-411. Technical and commercial history, with synopsis, characters, and geographic distribution of the extra-limital species, recent and fossil, as well as the North American.

Family Phocidæ, pp. 412-756. Technical history of the family, classification, synonymatic list of the genera and species, geographical distribution, fossil remains, milk-dentition, habits, migrations, locomotion on land, the seal-hunting industry and sealing-grounds, methods of capture, species hunted, products, decrease of seals from injudicious hunting, etc., pp. 412-557; systematic treatment of the North American species, pp. 557-756; Appendix: $a$, material examined (pp. 757-764); $b$, additions and corrections (pp. 765-773); index (pp. 775-785).

"A most valuable and complete history of these animals, especially of those found in North America, of their distribution and pursuit, with full synonymy, and copious tables and references. The history of the species of the group generally is also discussed, with remarks on their synonymy and distribution."-Zoöl. Rec. for 1880, Mamm. p. 2.

1 I employed Trichechus manatus Linné for the Florida Manatee as early as 1871 (see supra, No. 8). 
1881.

48. List of Mammals collected by Dr. Edward Palmer in Northeastern Mexico, with field-notes by the collector.<Bull. Mus. Comp. Zoöl., VIII, No. 9, March, 1881, pp. 183-189.

Annotated list of 25 species. Heteromys alleni Coues, sp. nov., ined., p. 187.

1882.

49. Preliminary List of Works and Papers relating to the Mammalian Orders Cete and Sirenia. <Bull. U. S. Geol. and Geogr. Surv., VI, No. 3, pp. 399-562, Aug. 30, 1882.

Covers the period from Albertus Magnus (1495) to the year 1840, and numbers 1013 annotated titles, the annotations in many cases amounting to a full statement of contents, so far as pertinent to the present subject, including names of species and genera and nature of treatment. All thus far published. The cause of the discontinuance of publication is explained in an insert, as follows:

"Owing to the illness of the author, which prevented his revision of the proof-sheets, it was necessary to stop the printing of the 'List' at the end of the year 1840. The present instalment comprises only a little more than one-third of the article; the remainder will be published as soon as the author's health renders it practicable.- J. A. Allen, Cambridge, Sept., 1882."

See further, a 'Personal Note' in Bull. Amer. Mus. Nat. Hist., XXIV, 1908, pp. 279-280.

1883.

50. Capture of the Crested Seal on the Coast of Massachusetts. <Science, I, No. 19, pp. 542-543, June 15, 1883.

51. The Right Whale of the North Atlantic.<Science, I, No. 21, pp. 598-599, June 29, 1883.

Review of Dr. J. B. Holder's paper on this subject (Bull. Amer. Mus. Nat. Hist., I, pp. 99-137, pll. x-xiii, May 30, 1883).

52. The Right Whale of the North Atlantic.<Science, II, No. 26, p. 134, Aug. 3, 1883.

Reply to Dr. Holder's rejoinder to above.

53. The Right Whale of the North Atlantic. <Science, II, No. 30, p. 267, Aug. 31, 1883.

Reply to a second rejoinder by Dr. Holder.

1884.

54. How long the Buffaloes remained in Illinois. <American Field, XXII, p. 128, Aug. 9, 1884.

Remained till as late as 1805 , and were not wholly extirpated till 1808 or 1809 ; not wholly destroyed by a heavy snowfall in 1763 , as stated by a previous correspondent.

55. The Mammals of the Adirondacks. <Science, IV, 1884, pp. 445-446.

Review of Dr. C. Hart Merriam's 'Vertebrates of the Adirondack Region, Northeastern New York,' Chap. II, Mammals (Trans. Linn. Soc. New York, I, 1882, pp. 27-106; II, 1884, pp. 9-214). 
1885.

56. What is the Present Distribution of the American Bison? $<$ Forest and Stream, XXIV, No. 8, p. 145, March 19, 1885.

A request for exact information as to its present numbers and distribution.

57. Prairie Dog Wells. <Forest and Stream, XXIV, No. 8, p. 145, March 19, 1885.

No evidence that prairie dogs ever burrow for water, but evidence to the contrary, and against considering "the prairie dog as a water witch," as believed by a previous correspondent.

58. On an Extinct Type of Dog from Ely Cave, Lee County, Virginia. $<M e m$. Mus. Comp. Zoöl., X, No. 2, pp. 1-8, pll. i-iii, Dec. 1885.

Pachycyon robustus sp. nov., p. 4. With 'On the Age of the Ely Cave,' by N. S. Shaler.

\section{7.}

59. The West Indian Seal (Monachus tropicalis).<Bull. Amer. Mus. Nat. Hist., II, pp. 1-34, pll. i-iv, April 25, 1887.

Introduction, pp. 1-3; external characters, pp. 4-6; osteological characters, pp. 6-19; sexual differences, pp. 20-21; affinities of the genus Monachus, pp. 22-23; general history, pp. 23-26; geographical distribution, pp. 27-29; habits, pp. 29-34.

60. Note on Squalodont Remains from Charleston, S. C. <Bull. Amer. Mus. Nat. Hist., II, pp. 34-39, pll. v-vi, April 25, 1887.

Squalodon tiedemani, sp. nov., p. 34. Based on the rostral portion of a skull, with teeth in situ.

61. The West Indian Seal.<Science, IX, No. 206, p. 35, Jan. 14, 1887.

Capture of specimens by Henry A. Ward at the Triangles, off Yucatan. Habits and distinguishing characters.

62. The West Indian Seal.<Science, IX, No. 207, p. 59, Jan. 21, 1887.

Notice of a paper on this species by F. W. True and F. A. Lucas, published in 1886, based on a female specimen taken near Havana, Cuba, in 1883.

1888.

63. List of Important Publications relating to Mammals. <Kingsley's Riverside Natural History, V, 1888, pp. 529-534.

About 130 titles.

1889.

64. Notes on a Collection of Mammals from Southern Mexico, with descriptions of new species of the genera Sciurus, Tamias, and Sigmodon. $<$ Bull. Amer. Mus. Nat. Hist., II, pp. 165-181, Oct. 21, 1889.

An annotated list of 16 species. Spp. et subspp. nov.: (1) Sciurus alstoni, p. 167 (name preoccupied and changed to nayaritensis, p. vii of same volume and Vol. III, p. 185); (2) Tamias asiaticus bulleri, p. 173; (3) Tamias asiaticus merriami, p. 176; (4) Sigmodon fulviventer, p. 180. 
65. Former Range of the Buffalo in Virginia. <New York Evening Post, Dec. 10, 1889.

Not found in the immediate vicinity of Washington, as alleged by a previous correspondent, but on the upper James River.

1890.

66. On Seasonal Variations in Color in Sciurus hudsonius. <Bull. Amer. Mus. Nat. Hist., III, pp. 41-44, June, 1890.

Based on a series of about 60 specimens, taken at Hastings, New York, and representing nearly every month of the year.

67. A Review of some of the North American ground Squirrels of the genus Tamias. <Bull. Amer. Mus. Nat. Hist., III, pp. 45-116, June, 1890.

24 species and subspecies are recognized, of which 13 are here first described, as follows:

(1) Tamias obscurus, p. 70; (2) T. senex, p. 83; (3) T. speciosus (Merriam, ined. MS.), p. 86;

(4) T. frater, p. 88; (5) T. amœenus, p. 90; (6) T. cinereicollis, p. 94; (7) T. umbrinus, p. 96;

(8) T. quadrivittatus gracilis, p. 99; (9) T. q. luteiventris, p. 101; (10) T. q. affinis, p. 103;

(11) T.q. neglectus, p. 106; (12) T. minimus consobrinus, p. 112; (13) T. m. pictus, p. 115.

68. Notes on a small collection of West Indian Bats, with description of an apparently new species.<Bull. Amer. Mus. Nat. Hist., III, pp. 169-173, Nov. 14, 1890.

An annotated list of 8 species, with critical comment on Artibeus "perspicillatus (Linn.)."

Artibeus coryi, sp. nov., p. 173.

69. Notes on collections of Mammals made in Central and Southern Mexico, by Dr. Audley C. Buller, with descriptions of new species of the genera Vespertilio, Sciurus, and Lepus. <Bull. Amer. Mus. Nat. Hist., III, pp. 175-194, Dec. 10, 1890.

Annotated list of 44 species, with additional notes on 3 species of Mexican Leporidæ. Spp. nov.: (1) Vespertilio velifer, p. 177; (2) Sciurus cervicalis, p. 183; (3) Lepus sylvaticus aztecus, p. 188; (4) Lepus insolitus, p. 189; (5) Lepus truei, p. 192.

70. Descriptions of a New Species and a New Subspecies of the Genus Lepus. <Bull. Amer. Mus. Nat. Hist., III, pp. 159-160, Oct., 1890.

(1) Lepus cinerascens, p. 153; (2) Lepus sylvaticus fl.ridanus, p. 160.

71. List of Mammals collected by Mr. Clark P. Streator in British Columbia, with descriptions of two new subspecies of Sciurus. <Bull. Amer. Mus. Nat. Hist., III, pp. 161-168.

Annotated list of 20 species. Subspp. nov.: (1) Sciurus hudsonius vancouverensis, p. 165; (2) S. h. californicus, p. 165.

1891.

72. Description of a new species of Big-eared Bat, of the genus Histiotus, from Southern California. <Bull. Amer. Mus. Nat. Hist., III, pp. 195-198, Feb. $20,1891$. 1892 .

Histiolus maculatus, sp. nov., p. 195. Later the type of the genus Euderma H. Allen, 
73. Notes on a Collection of Mammals from Costa Rica. <Bull. Amer. Mus. Nat. Hist., III, pp. 203-218, April 17, 1891.

38 species, the following new: (1) Blarina costaricensis, ${ }_{1}^{1}$ p. 205; (2) Hesperomys (Vesperimus) cherriei, p. 211; (3) Hesperomys (Vesperimus) nudipes, p. 213; (4) Hesperomys (Oryzomys) alfaroi, p. 214.

74. On a Collection of Mammals from Southern Texas and Northeastern Mexico. <Bull. Amer. Mus. Nat. Hist., III, pp. 219-228, April 17, 1891.

An annotated list of 31 species, the following new: (1) Scalops argentatus texanus, p. 221; (2) Dipodops sennetti, p. 226.

75. Description of a new species of Capromys, from the Plana Keys, Bahamas. <Bull. Amer. Mus. Nat. Hist., III, pp. 329-336, Aug. 31, 1891.

Capromys ingrahami, p. 329 , sp. nov.

76. Notes on new or little-known North American Mammals, based on recent additions to the Collection of Mammals in the American Museum of Natural History. <Bull. Amer. Mus. Nat. Hist., III, pp. 263-310, June 30, 1891.

Extended remarks on Heteromys alleni Coues, Dipodomys phillipsii Gray, Neotoma micro. pus Baird, Hesperomys indianus Wied (= Mus musculus Linn.), the generic name Hesperomys Waterhouse, and Mus agrarius americanus Kerr (1771) vs. Hesperomys leucopus auctorum (strictly, vs. Mus sylvaticus noveboracensis Fischer, 1829). Mus agrarius americanus shown later to be unavailable in this connection, through a previous Mus americanus Kerr.

Spp. et subspp. nov.: (1) Dipodops ordii palmeri, p. 276; (2) Dipodops richardsoni, p. 277;

(3) Perognathus (Chætodipus) femoralis, p. 281; (4) Neotoma micropus canescens, p. 285;

(5) Oryzomys aquaticus p. 289; (6) Vesperimus difficilis, p. 298; (7) Vesperimus nasutus, p. 299 ; (8) Vesperimus mearnsii, p. 300.

77. Recent work in North American Mammalogy.<Trans. New York Acad. Sci., X, No. 5, 1891, pp. 71-85.

A review of "recent progress" (1857-1891) in North American mammalogy.

78. Descriptions of two supposed new species of Mice from Costa Rica and Mexico, with remarks on Hesperomys melanophrys of Coues. <Proc. U. S. Nat. Mus., XIV, pp. 193-196, 1891.

Spp. nov.: (1) Oryzomys talamancæ, p. 193; (2) Hesperomys (Vesperimus) affinis, p. 195.

1892.

79. Description of a new species of Perognathus from Southeastern Texas. $<$ Bull. Amer. Mus. Nat. Hist., IV, pp. 45-46, pl. iii, March 25, 1892.

Perognathus merriami, p. 45.

80. On a small collection of Mammals from the Gallapagos Islands, collected by Dr. G. Baur. <Bull. Amer. Mus. Nat. Hist., IV, pp. 47-50, March 25, 1892.

4 species, 2 new, as follows: (1) Atalapha brachyotis, p. 47; (2) Oryzomys bauri, p. 48.

81. The Geographical Distribution of North American Mammals. <Bull. Amer. Mus. Nat. Hist., IV, pp. 199-244, pll. v-viii (maps).

Influences determining the geographic distribution of life (climatic), pp. 199-200; interrelation of land areas, pp. 200-201); mammals as the basis for the classification of life areas,

${ }^{1}$ Based on alcoholic specimens collected in all probability in the United States, wrongly attributed to Costa Rica, whence they were received by the author. 
pp. 202-203; systematic classification of life areas, pp. 203-211; the Sclaterian system, pp. 211-212; the mammals of North America considered in relation to the North American Region and its subdivisions, pp. 213-240, with 3 maps.

82. A synopsis of the Pinnipeds, or Seals and Walruses, in relation to their commercial history and products. $<$ Fur-seal Arbitration. Appendix to the case of the United States before the Tribunal of Arbitration, etc., I, 1892, pp. 367-391.

83. Fur-seal Hunting in the Southern Hemisphere. <Ibid., pp. 393-404.

84. The Alaskan Fur-seal and Pelagic Sealing.<Ibid., pp. 405-410.

85. Visitors' Guide to the Collection of Mammals in the American Museum of Natural History, Seventy-Seventh Street and Eighth Avenue, New York City. By J. A. Allen, Ph.D., Curator. New York: Printed for the Museum. 1892. $8^{\circ}$, pp. $1-89$. Diagram of hall and 24 cuts in text.

1893.

86. Rabbits and Hares.<Our Animal Friends, XX, No. 11, July, 1893, pp. 248251.

87. List of Mammals and Birds collected in Northeastern Sonora and Northwestern Chihuahua, Mexico, on the Lumholtz Archæological Expedition, 1890-92. <Bull. Amer. Mus. Nat. Hist., V, pp. 27-42, March 16, 1893.

Mammals, 17 species, pp. 28-32. Sciurus apache, sp. nov., p. 29.

88. Descriptions of Four New Species of Thomomys, with remarks on other Species of the Genus. <Bull. Amer. Mus. Nat. Hist., V, pp. 47-63, pl. i, April 28, 1893.

I. Descriptions of spp. nov.: (1) Thomomys monticolus, p. 48; (2) T. aureus, p. 49; (3) T. fossor, p. 51; (4) T. tollecus, p. 52. II. Questions of nomenclature, pp. 53-64. III. Cranial characters, pp. 64-65. IV. Species and subspecies of the genus Thomomys, pp. 66-67.

89. List of Mammals collected by Mr. Charles P. Rowley in the San Juan Region of Colorado, New Mexico and Utah, with descriptions of new species. <Bull. Amer. Mus. Nat. Hist., V, pp. 64-84, April 28, 1893.

Annotated list of 34 species. Spp. nov.: (1) Zapus princeps, p. 71; (2) Arvicola (Mynomes) aztecus, p. 73 ; (3) Reithrodontomys aztecus, p. 79 ; Sitomys auripectus, p. 75 ; S. rowleyi, p. 76.

90. On a Collection of Mammals from the San Pedro Martir Region of Lower California, with notes on other species, particularly of the genus Sitomys. <Bull. Amer. Mus. Nat. Hist., V, pp. 181-202, August 18, 1893.

Annotated list of 9 species. Spp. and subspp. nov.: (1) Sitomys americanus thurberi, p. 185; (2) S. martirensis, p. 187; (3) S. gilberti, p. 188; (4) Tamias leucurus peninsulæ, p. 197; (5) Scapanus anthonyi, p. 200.

Hesperomys gambelii Baird - type locality fixed as Monterey, Cal., p. 190; Hesperomys boylei Baird - type locality fixed as Middle Fork of the American River, El Dorado Co., Cal., p. 192; Hesperomys austerus Baird - type locality fixed as Fort Steilacoom, Puget Sound, p. 192. 
91. On a Collection of Mammals from the Island of Trinidad, with descriptions of new species. <Bull. Amer. Mus. Nat. Hist., V, pp. 203-234, Sept. 21, 1893. (With Frank M. Chapman.)

Annotated list of 34 species. Spp. nov.: (1) Chœronycteris intermedia, p. 207; (2) Nectomys palmipes, p. 209; (3) Tylomys couesi, p. 211; (4) Oryzomys speciosus, 212; (5) O. trinitatis, p. 213; (6) O. velutinus, p. 214; (7) O. brevicauda, p. 215; (8) Loncheres castaneus, p. 222 ; (9) Echimys trinitatis, p. 223.

List of known land mammals from Trinidad (65 species), pp. 231-234.

92. Further Notes on Costa Rican Mammals, with description of a new species of Oryzomys. <Bull. Amer. Mus. Nat. Hist., V, pp. 237-240, Sept. 22, 1893.

Annotated list of 18 species. O. costaricensis, sp. nov., p. 239.

93. Description of a new species of Opossum, from the Isthmus of Tehuantepec, Mexico. <Bull. Amer. Mus. Nat. Hist., V, pp. 235-236, Sept. 22, 1893.

Didelphys (Micoureus) canescens, sp. nov., p. 235.

94. Description of a new Mouse from Lake County, California.<Bull. Amer. Mus. Nat. Hist., V, pp. 335, 336, Dec. 16, 1893.

Sitomys robustus, p. 335 .

95. Description of a new species of Geomys from Costa Rica.<Bull. Amer. Mus. Nat. Hist., V, pp. 337, 338, Dec. 16, 1893.

Geomys cherriei, p. 337 .

1894.

96. Notes on Mammals from New Brunswick, with Description of a new Species. of Evotomys. <Bull. Amer. Mus. Nat. Hist., VI, pp. 99-106, April 14, 1894.

Annotated list of 33 species. Evotomys fuscodorsalis sp. nov., p. 103. Later found to bea melanistic phase of E. gapperi (see infra, No. 139).

97. On the Seasonal Change of Color in the Varying Hare (Lepus americanus Erxl.). <Bull. Amer. Mus. Nat. Hist., VI, pp. 107-128, April 14, 1894.

Change due to moult, not to change of color of the hair. Based on the study of about. 75 specimens collected in New Brunswick.

98. On the Mammals of Aransas County, Texas, with descriptions of new forms of Lepus and Oryzomys.<Bull. Amer. Mus. Nat. Hist., VI, pp. 165-198, May 31, 1894.

Annotated list of 36 species. Subspp. nov.: (1) Lepus sylvaticus mearnsii p. 171 (footnote); (2) Oryzomys palustris texensis, p. 177.

Table of cranial measurements and ratios of 34 North American specimens of the genus Mephitis (insert, facing p. 190); note on variability of coloration in species of Mephitis, pp. 192-196.

99. Cranial Variations in Neotoma micropus due to Growth and Individual Differentiation.<Bull. Amer. Mus. Nat. Hist., VI, 1894, pp. 233-246, pl. iv, August 3, 1894.

100. Remarks on Specimens of Chilonycteris rubiginosus from Western Mexico, and on the Color Phases of Pteronotus davyi Gray. <Bull. Amer. Mus. Nat. Hist., VI, 1894, pp. 247-248, August 3, 1894. 
101. Descriptions of ten new North American Mammals, and remarks on others. <Bull. Amer. Mus. Nat. Hist., VI, 1894, pp. 317-333, Nov. 7, 1894.

Spp. et subspp. nov.: (1) Perognathus pricei, p. 318; (2) Perognathus conditi, p. 318; (3) Reithrodontomys mexicanus fulvescens, p. 319; (4) Arvicola leucophæus, p. 320; (5) Sitomys americanus arizonæ, p. 321 ; (6) Neotoma campestris, p. 322 ; (7) Neotoma rupicola, p. 323; (8) Neotoma grangeri, p. 324; (9) Sciurus hudsonicus dakotensis, p. 325; (10) Phenacomys truei, p. 331. Remarks on Arvicola haydenii Baird and A. cinnamomeus Baird.

102. Recent Progress in the Study of North American Mammals. <Abst. Proc. Linnoean Soc. New York, for the year ending March 27, 1894, pp. 17-45, July 20, 1894.

A review of recent methods and results, with lists of the North American species of Lepus, Heteromys, Perognathus, Dipodomys, Perodipus, Thomomys, Geomys, Phenacomys, Evotomys, Arvicola, Neotoma, Sigmodon, Oryzomys, Sitomys, Sciurus, Tamias, Spermophilus, etc., in illustration of the subject.

103. Descriptions of five new North American Mammals. <Bull. Amer. Mus. Nat. Hist., VI, 1894, pp. 347-350, Dec. 7, 1894.

Spp. et subspp. nov.: (1) Arvicola insperatus, p. 347; (2) Lepus texianus eremicus, p. 347 ; (3) Lepus sylvaticus pinetis, p. 348; (4) Sciurus arizonensis huachuca, p. 349; (5) Sciurus hudsonicus grahamensis, p. 350 .

104. Remarks on a Second Collection of Mammals from New Brunswick, and on the Re-discovery of the Genus Neotoma in New York State. $<$ Bull. Amer. Mus. Nat. Hist., VI, 1894, pp. 359-364, Dec. 22, 1894.

Notes on 7 species, pp. 359-361. Capture of Neotoma pennsylvanicus Stone on Storm King Mountain, Orange Co., N. Y.; and reference to its long previous record of occurrence at Piermont, Rockland Co., N. Y., pp. 362-364.

1895.

105. On the Species of the Genus Reithrodontomys. < Bull. Amer. Mus. Nat. Hist., VII, 1895, pp. 107-143, May 21, 1895.

A monographic revision; 15 species and subspecies recognized, the following new: (1) R. merriami, p. 119; (2) R. dychei, p. 120; (3) R. dychei nebrascensis, p. 122; (3) R. megalotis deserti, p. 127; (4) R. arizonensis, p. 134; (5) R. mexicanus intermedius, p. 136; (6) $R$. $m$. aurantius, p. 137; (7) R. costaricensis, p. 139.

106. On the Names of Mammals given by Kerr in his 'Animal Kingdom,' published in 1792. <Bull. Amer. Mus. Nat. Hist., VII, pp. 179-192, June 20, 1895.

Four generic and 16 specific names antedate current names taken from later authors; as follows: Myocastor = Myopotamus Geoffroy, 1805 (p. 182); Cricetus = Cricetus Cuvier, 1817 (p. 183); Myotalpa = Siphneus Brants, 1827 (p. 183); Lynx $=$ Lynx Rafinesque, 1818 (p. 182). The necessary changes in specific names are:

Cercocebus torquatus (Kerr) = C. collaris Gray, 1843 (p. 185)

Nasalis nasuus (Kerr) $=N$. nasalis (Shaw), 1800 (p. 186).

Colobus badius $($ Kerr) = C. ferruginea (Shaw), 1800 (p. 186).

Cebus albulus (Kerr) = C. hypoleucus Humb., 1811 (p. 186).

Priodon maximus (Kerr) = P.gigas (Cuvier), 1817 (p. 187).

Mastodon americanus (Kerr) = M. giganteus Cuvier, 1817 (p. 187).

Canis australis Kerr = C. antarcticus Shaw, 1800 (p. 188).

Crocidura cærulea (Kerr) = C. cærulescens (Shaw), 1800 (p. 188).

Petaurus norfolcensis (Kerr) =P. sciurea (Shaw), 1794 (p. 190).

Alce fossilis (Kerr) [ = A. gigantea ${ }^{1}$ Blumenb., 1799 (p. 191).]

${ }^{1}$ By error "Cervus giganteus Goldfuss, 1821 " is cited instead of Alce giganteus Blumenbach, 1799. 
Mazama temama (Kerr) = M. tema Rafinesque, ${ }^{1} 1817$.

Ovis europæa (Kerr) = O. musimon Auct. ex Pallas, 1811 (p. 192).

Lynx texensis nom. nov. (p. 188) is given to replace Felis maculata Horfs. and Vigors (1829), preoccupied by Felis (Lynx) vulgaris maculatus Kerr, for the Texas lynx.

107. On a Collection of Mammals from Arizona and Mexico, made by Mr. W. W. Price, with Field Notes by the Collector.<Bull. Amer. Mus. Nat. Hist., VII, pp. 193-258, fig. 1-17, June 29, 1895.

Annotated list of 70 species collected and 16 others observed but not collected, making a total of 86 species, with important field notes, extended measurements and technical comment.

Cervus hemionus Raf., 1817, replaces C. macrotis Say, 1823; Ovis cervina Desm., replaces O. canadensis Shaw. Thomomys cervinus, sp. nov., p. 203.

108. List of Mammals collected in the Black Hills Region of South Dakota and in Western Kansas by Mr. Walter W. Granger, with Field Notes by the Collector. <Bull. Amer. Mus. Nat. Hist., VII, pp. 259-274, August 21, 1895.

Annotated list of $53 \mathrm{spp}$. Lepus sylvaticus grangeri subsp. nov., p. 264.

109. Descriptions of new American Mammals.<Bull. Amer. Mus. Nat. Hist., VII, pp. 327-340, Nov. 8, 1895.

Spp. et subspp. nov.: (1) Lepus aquaticus attwateri, p. 327; (2) Reithrodontomys australis, p. 328; (3) Oryzomys cherriei, p. 329; (4) Peromyscus attwateri, p. 330; (5) Neotoma cinnamomea, p. 331; (6) Sciurus (Microsciurus, subgen. nov.) alfari, p. 333; (7) Tamias pricei, p. 333; (8) Tamias wortmani, p. 335; (9) Spermophilus tridecemlineatus olivaceus, p. 337; (10) S. t. parvus, p. 337; (11) Blarina (Soriciscus) nigrescens, p. 339; (12) B. (S.) orophila, p. 340 .

110. Monographic Revision of the Pocket Gophers, Family Geomyidæ (exclusive of the genus Thomomys). <Science, N. S., I, pp. 241-243, March 1, 1895.

Review of Dr. C. Hart Merriam's paper of this title in N. Am. Fauna, No. 8, 1895.

111. The Pocket Gophers of the United States.<Science, N. S., I, pp. 689-690, June 21, 1895.

Review of paper by Vernon Bailey in Bull. No. 5, U. S. Dept. Agric., 1895.

112. Those Pocket Gophers. Another Contribution about the Literature and Habits of the Geomyidæ. <New York Sun (newspaper), Feb. 26, 1895.

A humorous reply to abusive criticism of Dr. C. Hart Merriam's 'Monographic Revision of the Pocket Gophers' (N. Amer. Fauna, No. 8, Jan. 1895), under the pseudonym "Thomas Jones."

1896.

113. Note on Macrogeomys cherriei (Allen).<Bull. Amer. Mus. Nat. Hist., VIII, pp. 45-46, pl. i, April 15, 1896.

Geomys cherriei further described and skull figured (cf. supra, No. 95).

114. On Mammals collected in Bexar County and Vicinity, Texas, by Mr. H. P. Attwater, with Field Notes by the Collector. <Bull. Amer. Mus. Nat. Hist., VIII, pp. 47-80, April 22, 1896.

Annotated list of $53 \mathrm{spp}$.

1 Cervus temama Kerr and Mazama tema Rafinesque I have recently rejected as indeterminable, accepting instead Cervus sartorii Saussure (cf. Bull. Amer. Mus. Nat. Hist., XXXIV, p. 541, Nov. 2, 1915). 
115. Descriptions of new North American Mammals.<Bull. Amer. Mus. Nat. Hist., VIII, 1896, pp. 233-240, pll. x and xi, Nov. 21, 1896.

Spp. et subspp. nov.: (1) Rangifer terrænovæ, p. 233 ( = R. terrænovæ Bangs of 11 days earlier date): (2) Reithrodontomys laceyi, p. 235; (3) Perognathus mearnsi, p. 237 ; (4) Peromyscus michiganensis pallescens, p. 238; (5) Vespertilio incautus, p. 239; (6) Vespertilio chrysonotus, p. 340 .

116. List of Mammals collected by Mr. Walter W. Granger, in New Mexico, Utah, Wyoming and Nebraska, 1895-96, with Field Notes by the Collector. $<$ Bull. Amer. Mus. Nat. Hist., VIII, pp. 241-258, Nov. 25, 1896.

Annotated list of $48 \mathrm{spp}$.

117. On Mammals from the Santa Cruz Mountains, California.<Bull. Amer. Mus. Nat. Hist., VIII, pp. 263-270, Dec. 4, 1896.

Annotated list of 16 species, with records of large series of measurement of various species of Muridæ and one shrew.

117a. North American Shrews. <Science, N. S., III, pp. 411-413, March 13, 1896.

Review of papers by C. Hart Merriam and Gerrit S. Miller, Jr., pablished in N. Amer. Fauna, No. 10, Dec. 31, 1895.

1897.

118. On Mammals from Yucatan, with Descriptions of New Species. $<$ Bull. Amer. Mus. Nat. Hist., IX, pp. 1-12, Feb. 23, 1897. With Frank M. Chapman.

Annotated list of 15 species, with 3 new, as follows: (1) Peromyscus yucatanicus, p. 8; (2) Reithrodontomys mexicanus gracilis, p. 9; (3) Heteromys gaumeri, p. 9.

119. On a Second Collection of Mammals from the Island of Trinidad, with descriptions of New Species, and a Note on some Mammals from the Island of Dominica, W. I. <Bull. Amer. Mus. Nat. Hist., IX, pp. 13-30, Feb. 26, 1897. With Frank M. Chapman.

The annotated list of Trinidad species numbers 40, with the following new: (1) Artibeus palmarum, p. 16; (2) Oryzomys delicatus, p. 19; (3) Akodon urichi, p. 19; (4) Akodon frustrator, p. 20: (5) Thylamys carri, p. 27.

Five species recorded from Dominica.

120. Additional Notes on Costa Rica Mammals, with Descriptions of New Species. <Bull. Amer. Mus. Nat. Hist., IX, pp. 31-43, pl. i, March 11, 1897.

Annotated list of 66 species, with 2 new genera and 4 new species, as follows: Genn. nov.: Zygodontomys, p. 38; Sigmodontomys, p. 38 . Spp. nov.: (1) Artibeus intermedius, p. 33; (2) Oryzomys chrysomelas, p. 37; (3) Sigmodontomys alfari, p. 39; (4) Sigmodon borucx, p. 40.

121. Further Notes on Mammals Collected in Mexico by Dr. Audley C. Buller, with Descriptions of New Species. <Bull. Amer. Mus. Nat. Hist., IX, pp. 47-58, March 15, 1897.

An annotated list of 35 species, with the following as new: (1) Peromyscus spicilegus, p. 50; (2) Peromyscus banderanus, p. 51; (3) Oryzomys mexicanus, p. 52; (4) Oryzomys bulleri, p. 53; (5) Sigmodon mascotensis, p. 54; (6) Sigmodon colimæ, 55; (7) Heteromys hispidus, p. 56.

122. Preliminary Description of a new Mountain Sheep from the British Northwest Territory. <Bull. Amer. Mus. Nat. Hist., IX, pp. 111-114, pll. ii and iii, April 8, 1897.

Ovis stonei, sp. nov. 
123. On a Small Collection of Mammals from Peru, with Descriptions of New Species. <Bull. Amer. Mus. Nat. Hist., IX, pp. 115-119, April 26, 1897.

Spp. 12, with 3 new: (1) Sciurus (Microsciurus) peruanus, p. 115; (2) Oryzomys baroni, p. 118; Sigmodon peruanus. p. 118.

124. Description of a new species of Sigmodon, from Bogotá, Colombia. <Bull. Amer. Mus. Nat. Hist., IX, pp. 121-122, May 24, 1897.

Sigmodon bogotensis, sp. nov.

125. On a Collection of Mammals from Jalapa and Las Vigas, State of Vera Cruz, Mexico.<Bull. Amer. Mus. Nat. Hist., IX, pp. 197-208, June 16, 1897. With Frank M. Chapman.

Annotated list of 19 species with 7 new: (1) Mus musculus jalapæ, p. 198; (2) Reithrodontomys rafescens, p. 199; (3) Reithrodontomys saturatus, p. 201; (4) Peromyscus furvus, p. 201; (5) Peromyscus melanotis, p. 203; (6) Peromyscus musculus brunneus, p. 203; (7) Oryzomys jalapæ, p. 206.

126. Description of a new Vespertilionine Bat from Yucatan. <Bull. Amer. Mus. Nat. Hist., IX, pp. 231-232, Sept. 28, 1897.

Adelonycter is gaumeri, sp. nov.

1898.

127. Descriptions of new Mammals from Western Mexico and Lower California. <Bull. Amer. Mus. Nat. Hist., X, pp. 143-158, April 12, 1898.

Spp. et subspp. nov.: (1) Marmosa sinaloæ, p. 143; (2) Lepus peninsularis, p. 144; (3) Lepus cerrosensis, p. 145; (4) Lepus arizonæ confinis, p. 146; (5) Thomomys fulvus anitæ, p. 146; (6) Thomomys fulvus martirensis, p. 147; (7) Thomomys atrovarius, p. 148; (8) Perognathus pernix, p. 149; (9) Neotoma sinaloæ, p. 149; (10) Neotoma arenacea, p. 150; (11) Neotoma anthonyi, p. 151; (12) Peromyscus eremicus propinquus, p. 154; (13) Peromyscus cedrosensis, p. 154; (14) Peromyscus cineritius, p. 155; (15) Peromyscus geronimensis, p. 156; (16) Peromyscus exiguus, p. 157; (17) Peromyscus dubius, p. 157.

Neotoma bryanti Merriam redescribed from a series of good specimens, pp. 152-15̄.

128. Revision of the Chickarees, or North American Red Squirrels (subgenus Tamiasciurus).<Bull. Amer. Mus. Nat. Hist., X, pp. 249-298, August 31, 1898.

Monographic revision. Subspp. nov.: (1) Sciurus hudsonicus baileyi, p. 261; (2) Sciurus hudsonicus ventorum, p. 263; (3) Sciurus hudsonicus streatori, p. 267; (4) Sciurus douglasii cascadensis, p. 277; (5) Sciurus fremonti neomexicanus, p. 291.

Sciurus douglasii mollipilosus Aud. \& Bachm. revived to replace Sciurus hudsonicus orarius Bangs, 1897, p. 277.

129. Nomenclatorial Notes on certain North American Mammals. <Bull. Amer. Mus. Nat. Hist., X, pp. 449-461, Nov. 10, 1898.

Sciurus rubricatus Ord (1818), Sciurus bottæ Lesson (1831), names of too doubtful significance to be employed; Sciurus californicus Lesson (1847), of doubtful application, but renders Sciurus hudsonicus californicus Allen (1890) untenable, which is here replaced by Sciurus douglasii albolimbatus (nom. nov.), p. 453; Sciurus griseus Ord (1818) antedates Sciurus fossor Peale (1848) for the same species; Spermophilus empetra (Pallas, 1778) is again affirmed to $=$ S. parryi Richardson; Arctomys lewsii Aud. \& Bach. (1853), an earlier name for Cynomys leucurus Merriam (1890); Glis canadensis Erxleben (1777) = Arctomys monax melanopus Kuhl (1820); Arctomys pruinosus Gmelin (1788) = A. caligatus Eschscholtz (1829); Hypudæus ochrogaster Wagner (1843) = Microtus austerus LeConte (1853); Lutra canadensis 
Schreber, 1776) the correct name of the common Otter of North America (vs. Rhoads); Mustela pennanti Erxleben (1777) the correct name for the Fisher (vs. Rhoads).

Sciurus wagneri nom. nov. for Sciurus albipes et $S$. varius Wagner, preoccupied ( = Sciurus poliopus Fitzinger).

130. A Pocket Mouse in Confinement. <Amer. Nat., XXXII, pp. 583-584, August, 1898.

A specimen of Perognathus mearnsi lived in a cage at the American Museum of Natural History for about four years in good health without partaking of water, though water was offered it, showing that water was not necessary to its welfare.

131. The Sea Otter.<Amer. Nat., XXXII, pp. 356-358, May, 1898.

On their greatly reduced numbers, based on a report to U. S. Government by Capt. V. L. Hooper, Commanding Bering Sea Patrol Fleet, 1897. (Treas. Dept. Rep., Dec. 1897.)

132. The Mammals of Florida. <Amer. Nat., XXXIII, pp. 433-436, June, 1898.

Review of Outram Bangs's paper 'The Land Mammals of Peninsular Florida and the Coast Region of Georgia' (Proc. Boston Soc. Nat. Hist., XXVIII, 1898).

1899.

133. Trouessart's Catalogue of Mammals.<Amer. Nat., XXXIII, pp. 69-70, Jan., 1899.

Review of second edition of Trouessart's 'Catalogus Mammalium tam Viventium quam Fossilium,' 1897.

134. Generic and Family Names of Rodents.<Amer. Nat., XXXIII, pp. 70-72, Jan., 1899.

Review of Thomas's 'On the Genera of Rodents' (Proc. Zool. Soc. London, 1896, pp. 10121018) and Palmer's 'A List of the Generic Names of Rodents' (Proc. Biol. Soc. Washington, XI, pp. 241-270, Dec. 7, 1897).

135. The Fossil Bisons of North America.<Amer. Nat., XXXIII, pp. 665-666, August, 1899.

Review of Lucas's paper (Proc. U. S. Nat. Mus., XXI, pp. 755, 771, pls. lxv-lxxxiv, and text figures).

136. 'Wild Animals I have Known.' < Amer. Nat., XXXIII, pp. 666-668, August, 1899.

Review of E. S. Thompson's book thus entitled (New York, 1898).

137. The North American Arboreal Squirrels.<Amer. Nat., XXXIII, August, 1899, pp. 635-642.

A review of E. W. Nelson's 'Revision of the Squirrels of Mexico and Central America' (Proc. Washington Acad. Sci., I, pp. 15-110, pll. i and ii, May, 1899), to which is here added a list of the 'Arboreal Squirrels found in North America north of Mexico,' with their geographic ranges.

138. Report of the Fur Seal Investigations, 1896-1897. <Science, N. S., X, pp. 885-890, Dec. 15, 1899.

Review of 'The Fur Seals and Fur Seal Islands of the North Pacific,' by David Starr Jordan, Commissioner in Charge of Fur Seal Investigations, 1896-1897. 
139. On Mammals from the Northwest Territory collected by Mr. A. J. Stone. <Bull. Amer. Mus. Nat. Hist., XII, pp. 1-9, March 4, 1899.

Annotated list of 17 species, the following new: (1) Zapus saltator, p. 3; (2) Phenacomys constablei, p. 4; (3) Microtus stonei, p. 5; (4) Microtus vellerosus, p. 7; (5) Microtus cautus, p. 7. Also note on Evotomys fuscodorsalis Allen = E. gapperi (Vigors).

140. Descriptions of new North American Rodents. <Bull. Amer. Mus. Nat. Hist., XII, pp. 11-17, March 4, 1899.

Spp. et subspp. nov.: (1) Lepus americanus phæonotus, p. 11; (2) Lepus bishopi, p. 11; (3) Lepus floridanus chapmani, p. 13; (4) Thomomys fulvus alticolus, p. 13; (5) Reithrodontomys tenuis, p. 15; (6) Peromyscus texanus subarcticus, p. 15; (7) Sciurus chapmani, p. 16.

141. New Rodents from Colombia and Venezuela.<Bull. Amer. Mus. Nat. Hist., XII, pp. 195-218, Dec. 20, 1899.

Spp. et subspp. nov.: (1) Lepus (Sylvilagus) superciliaris, p. 196; (2) Isothrix rufodorsalis, p. 197; (3) Echimys mincx, p. 199; (4) Echimys urichi, p. 199; (5) Echimys canicollis, p. 200; (6) Heteromys jesupi, p. 201; (7) Akodon venezuelensis, p. 203; (8) Akodon columbianus, p. 203; (9) Oryzomys maculiventer, p. 204; (10) Oryzomys trichurus, p. 206; (11) Oryzomys sanctæmartæ, p. 207; (12) Oryzomys mollipilosus, p. 208; (13) Oryzomys magdalenæ, p. 209 ; (14) Oryzomys villosus, p. 210; (15) Oryzomys palmarius, p. 210; (16) Oryzomys tenuicauda, p. 211; (17) Oryzomys modestus, p. 212; (18) Oryzomys fulviventer, p. 212; (19) Sciurus saltuensis bondæ, p. 213; (20) Sciurus (Guerlinguetus) quebradensis, p. 217.

142. The Generic Names Echimys and Loncheres.<Bull. Amer. Mus. Nat. Hist., XII, pp. 257-264, Dec. 26, 1899.

On Echimys, Loncheres, Dactylomys, Nelomys and Mesomys. Loncheres = Echimys of earlier date; Proechimys gen. nov., to replace Echimys auct., not of F. Cuvier, 1809.

1900.

143. The Mountain Caribou of Northern British Columbia.<Bull. Amer. Mus. Nat. Hist., XIII, 1900, pp. 1-18, fig. 1-18, April 3, 1900.

Comparison with other forms; referred to Rangifer montanus Seton-Thompson, but later (see below, No. 179) became Rangifer osborni Allen. Skull and antlers figured.

144. Note on the Wood Bison. <Bull. Amer. Mus. Nat. Hist., XIII, 1900, pp. 6367, April 16, 1900.

Its range, former and present, and approximate present number of individuals living.

145. List of Bats collected by Mr. H. H. Smith in the Santa Marta region of Colombia, with descriptions of new species. <Bull. Amer. Mus. Nat. Hist., XIII, pp. 87-94, May 12, 1900.

Annotated list of 22 species, the following new: (1) Chiroderma jesupi, p. 88; (2) Micro nycteris hypoleuca, p. 90; (3) Promops affinis, p. 91; (4) Promops milleri, p. 92.

146. Note on the Generic Names Didelphis and Philander. $<$ Bull. Amer. Mus. Nat. Hist., XIII, pp. 185-190, Oct. 12, 1900.

Philander considered a synonym of Didelphis. Caluromys nom. nov. is proposed for Philander auct., with Didelphis philander designated as type. ${ }^{1} \quad$ Caluromys alstoni $\mathbf{s p .}$ nov., p. 189.

1 Later, under the action of the principle of tautonymy, Philander became reinstated, leaving Caluromys a pure synonym of Philander. 
147. Descriptions of new American Marsupials.<Bull. Amer. Mus. Nat. Hist., XIII, 1900, pp. 191-199, Oct. 23, 1900.

Spp. et subspp. nov.: (1) Didelphis pernigra, p. 191; (2) Didelphis karkinophaga caucæ, p. 192; (3) Didelphis karkinophaga colombica, p. 193; (4) Metachirus fuscogriseus, p. 194; (5) Metachirus tschudii, p. 195; (6) Metachirus nudicaudatus colombianus, p. 196; (7) Marmosa chapmani, p. 197; (8) Marmosa klagesi, p. 198; (9) Thylamys keaysi, p. 198.

148. On Mammals collected in Southeastern Peru by H. H. Keays, with Descriptions of new species. <Bull. Amer. Mus. Nat. Hist., XIII, pp. 219-227, Nov. 16, 1900.

Eighteen species, 5 new, as follows: (1) Dactylomys peruanus, p. 220; (2) Oxymycterus juliacæ, p. 223; (3) Oxymycterus apicalis. p. 224; (4) Oryzomys keaysi, p. 225; (5) Oryzomys obtusirostris, p. 226.

149. Some Results of a Natural History Journey to Northern British Columbia, Alaska and the Northwest Territory, in the interest of the American Museum of Natural History. By A. J. Stone.<Bull. Amer. Mus. Nat. Hist., XIII, pp. 31-62, April 6, 1900.

Introductory Note and technical names by J. A. Allen.

150. The systematic name of the Cuban Red Bat.<Proc. Biol. Soc. Washington, XIII, 165, Oct. 31, 1900.

Lasiurus pfeifferi (Gundlach) - not L. blossevillii = L. bonariensis (Lesson \& Garnot).

151. The proper name of the Viscacha.<Proc. Biol. Soc. Washington, XIII, 183, Nov. 30, 1900.

Vizcacia viscacia (Molina).

152. The North American Jumping Mice.<Amer. Nat., XXXIV, pp. 199-202, March, 1900.

Review of E. A. Preble's 'Revision of the Jumping Mice of the Genus Zapus,' in N. Amer. Fauna, No. 15, 1899, with a list of the species and subspecies, giving their ranges.

153. Preliminary List of the Mammals of New York. <Amer. Nat., XXXIV, pp. 316-318, April, 1900.

Review of G. S. Miller's 'Preliminary List of New York Mammals,' in Bull. New York State Mus., VI, 1899, pp. 271-390.

1901.

154. The generic names Myrmecophaga and Tamandua, and the specific names of the Opossums of the genus Didelphis. <Proc. Biol. Soc. Washington, XIV, pp. 91-93, June 19, 1901.

Myrmecophaga tridactyla Linn.; Tamanduas F. Cuvier (1829) has priority over Uroleptes Wagler (1830); Didelphis marsupialis Linn. restricted to the Guiana form of the genus.

155. The proper generic names of the Viscacha, Chinchillas and their allies. <Proc. Biol. Soc. Washington, XIV, 181-182, Dec. 12, 1901.

Respectively Viscacia Schinz (1825), Chinchilla and Lagidium; Callomys is indeterminable.

156. Descriptions of two new species of South American Muridæ. <Bull. Amer. Mus. Nat. Hist., XIV, pp. 39-40, Jan. 31, 1901.

Spp. nov., (1) Zygodontomys thomasi, p. 39; (2) Sigmodon simonsi, p. 40. 
157. On a Further Collection of Mammals from Southeastern Peru, collected by Mr. H. H. Keays, with Descriptions of new species.<Bull. Amer. Mus. Nat. Hist., XIV, pp. 41-46, Jan. 31, 1901.

An annotated list of 18 species. Spp. nov.: (1) Rhipidomys ochrogaster, p. 43; (2) Phyllotis osilæ, p. 44; (3) Akodon lutescens, p. 46.

158. The Musk-oxen of Arctic America and Greenland.<Bull. Amer. Mus. Nat. Hist., XIV, pp. 69-86, pll. xiii-xvii, and 7 text figures, March 27, 1901.

Principally on the Ellesmere Land form, here referred to Ovibos wardi Lydekker $(=0$. pearyi Allen, Ms.).

159. Description of a new Caribou from Kenai Peninsula Alaska. $<$ Bull. Amer. Mus. Nat. Hist., XIV, pp. 143-148, and 4 text figures, May 28, 1901.

Rangifer stonei sp. nov.

160. A Preliminary Study of the North American Opossums of the Genus Didelphis. <Bull. Amer. Mus. Nat. Hist., XIV, pp. 149-188, pll. xxii-xxv, June 15, 1901.

Spp. and subspp. nov.: (1) Didelphis marsupialis texensis, p. 172; (2) Didelphis marsupialis tabascensis, p. 173; (3) Didelphis richmondi, p. 175; (4) Didelphis yucatanensis, p. 178.

161. Descriptions of two new Opossums of the Genus Metachirus. $<$ Bull. Amer. Mus. Nat. Hist., XIV, pp. 213-218, July 3, 1901.

Spp. nov.: (1) Metachirus fuscogriseus pallidus, p. 215; (2) Metachirus grisescens, p. 217.

162. The generic names of the Mephitinæ. <Bull. Amer. Mus. Nat. Hist., XIV, pp. 325-334, Nov. 12, 1901.

Chinca Lesson (1842) a synonym of Mephtis Cuvier (1800); Spilogale Gray (1865) is not a synonym of Mephitis, as construed by Howell (N. Amer. Fauna, No. 20, Aug. 31, 1901).

A list of the species and subspecies of Mephitis is given (pp. 333, 334).

163. New South American Muridæ and a new Metachirus. <Bull. Amer. Mus. Nat. Hist., XIV, pp. 405-412, Nov. 30, 1901.

Spp. nov.: (1) Oryzomys bolivaris, p. 405; (2) Oryzomys castaneus, p. 406; (3) Oryzomys perenensis, p. 406; (4) Oryzomys rivularis, p. 407; (5) Phyllotis chacoensis, p. 408; (6) Phyllotis cachinus, p. 409; (7) Eligmodontia morgani, p. 409; (8) Akodon tucumanensis, p. 410; (9) Metachirus nudicaudatus bolivianus, p. 411.

164. Mammals of South Africa. <Science, N. S., XIII, pp. 105-106, Jan. 18, 1901.

Review of Volume I of W. L. Sclater's work of this title.

165. Miller's Key to the Land Mammals of Eastern North America. <Amer. Nat., XXXV, pp. 59-61, Jan., 1901.

Review of G. S. Miller's paper thus entitled, with criticism of certain points of nomenclature, as the use of Rosmarus in place of the earlier Odobenus, etc.

166. Two Important Papers on North American Mammals. $<$ Amer. Nat., XXXV, pp. 221-224, March, 1901.

Bailey's 'Revision of American Voles of the Genus Microtus,' and Osgood's 'Revision of the Pocket Mice of the Genus Perognathus.' 
1902.

167. Beddard's 'Mammalia.' <Amer. Nat., XXXVI, pp. 911-914, Nov., 1902.

Review of this excellent manual (Cambridge Natural History, Vol. X, London, 1902).

168. Note on the Names of a few South American Mammals.<Proc. Biol. Soc. Washington, XIV, pp. 183-185, Dec. 12, 1901.

Several species names date from G. Fischer, 1814, which are usually attributed to later authors; several names attributed to Wied were first published by Schinz (1821), or by Kuhl, or by Temminck; Gray's names (1827) for certain genera of bats antedate later names now current, etc.

169. A Further Note on the Generic Names of the Mephitinæ.<Proc. Biol. Soc. Washington, XV, pp. 59-60, March 22, 1902.

Apropos of Howell's replacing Mephitis by Chincha and Spilogale by Mephitis.

170. A Further Note on the Name of the Argentine Viscacha.<Proc. Biol. Soc. Washington, XV, 196, Oct. 10, 1902.

Viscaccia dates from Oken, 1816, instead of from Schinz, 1825; the specific name chilensis Oken (1816) has priority over maximus Desmarest (1817) - hence Viscaccia chilensis Oken for the Argentine Viscacha.

171. North American Ruminants. <Amer. Mus. Journal, II, March, 1902, Supplement (= Guide Leaflet, No. 5), pp. 1-29. 18 half-tone illustrations.

172. The Caribou of British Columbia and Alaska. <Outing, 1902, pp. 555-561, 11 text figures.

Distribution, characters and habits of Rangifer montanus, $R$. osborni, R. granti, and $R$. stonei.

173. North American Deer.<Amer. Nat., XXXVI, pp. 755-756, Sept., 1902.

Review of the work entitled 'The Deer Family,' by Theodore Roosevelt and others.

174. Zimmermann's 'Zoologiæ Geographicæ' and 'Geographische Geschichte' considered in their relation to Mammalian Nomenclature. <Bull. Amer. Mus. Nat. Hist., XVI, pp. 13-22, Feb. 1, 1902.

Various names in the 'Geschichte' (1780) were previously employed in the 'Geographicæ' (1777) and thus take an earlier date; others antedate Erxleben (1777) to whom they are usually accredited. Dama virginiana Zimm., 1777, is considered tenable for the common Virginia Deer. Dama lichtensteini (p. 20) is a new name for Cervus mexicanus Lichtenstein, preoccupied by Cervus mexicanus Zimmermann and Gmelin, which is shown to have been based mainly on the Prong-horn (Antilocapra americana).

175. The Generic and Specific Names of some of the Otariidæ. $<$ Bull. Amer. Mus. Nat. Hist., XVI, pp. 111-118, March 15, 1902.

Eumetopias stelleri (Lesson, 1828) becomes E. jubata (Schreber, 1776); the first tenable specific name of the Southern Sea Lion is shown to be byronia Blainville (1820); the generic name of the northern Fur Seals is shown to be Callotaria Palmer, 1892, not Otoes Palmer, 1901 = Otaria Peron, 1816 .

176. A new Caribou from the Alaska Peninsula.<Bull. Amer. Mus. Nat. Hist., XVI, pp. 119-127, and 6 text figures, April 7, 1902.

Rangifer granti, sp. nov. 
177. A new Bear from the Alaska Peninsula. <Bull. Amer. Mus. Nat. Hist., XVI, pp. 141-143, pll. xxx, and xxxi, April 12, 1902.

Ursus merriami sp. nov. Skull and dentition figured.

178. A new Sheep from the Kenai Peninsula. <Bull. Amer. Mus. Nat. Hist., XVI, pp. 145-148, and 2 text figures, April 23, 1902.

Ovis dalli kenaiensis subsp. nov.

179. Description of a new Caribou from Northern British Columbia, and remarks on Rangifer montanus. <Bull. Amer. Mus. Nat. Hist., XVI, pp. 149-158, and 6 text figures. April 16, 1902.

Rangifer osborni, sp. nov.; skulls of true Rangifer montanus figured.

180. Nomenclatorial Notes on American Mammals. <Bull. Amer. Mus. Nat. Hist., XVI, pp. 159-168, July 1, 1902.

Alce Blumenbach (1803 [lege 1799]) replaces Megaceros Owen (1844) for the extinct Irish Elk. Alce (non Blumenbach, Alces auct.) is changed to Paralces, nom. nov., p. 160. Dama vs. Odocoileus is again considered, anent comment on the case by Osgood. The names of the Peccaries, both generic and specific, are discussed, and a list of the species with their synonymy is given, the specific name pecari Fisher (1814) replacing albirostris Illiger (1815) and also labiatus Cuvier (1817). Sciurus rufiventer E. Geoffroy (1803) is adopted in place of S. ludovicianus Custis (1806).

181. List of Mammals collected in Alaska by the Andrew J. Stone Expedition of 1901. <Bull. Amer. Mus. Nat. Hist., XVI, pp. 215-230, July 12, 1902.

An annotated list of 26 species, with field notes by J. D. Figgins, collector.

182. A Preliminary Study of the South American Opossums of the Genus Didelphis. <Bull. Amer. Mus. Nat. Hist., XVI, pp. 249-279, Aug. 18, 1902.

A monographic revision, with copious tables of measurements. Subspp. nov.: (1) Didelphis marsupialis insularis, p. 259; (2) D. m. etensis, p. 262; (3) D. paraguayensis andina, p. 272; (4) D. p. meridensis, p. 274. D. paraguayensis Oken (1816) replaces D. aurita Temminck (1825).

183. Mammal Names proposed by Oken in his 'Lehrbuch der Zoologie.' <Bull. Amer. Mus. Nat. Hist., XVI, pp. 373-379, Oct. 11, 1902.

Generic names considered available are Citellus, Grison, Tayra, Thos, Panthera, Tigris, Leo. The specific names considered available, or as rendering invalid later similar names, are Lepus chilensis, for the Argentine Viscacha; Hystrix paraguayensis, for Spiggurus spinosa F. Cuvier; Felis $(\operatorname{Lynx})$ brasiliensis, unidentifiable with certainty, but precludes a later Felis brasiliensis (as of Schinz and F. Cuvier); Felis (Panthera) mexicana = Felis mexicana Desm. of even date.

184. A new Caribou from Ellesmere Land.<Bull. Amer. Mus. Nat. Hist., XVI, pp. 409-412, with 2 text figures, Oct. 31, 1902.

Rangifer pearyi sp. nov.

185. The Hair Seals (Family Phocidæ) of the North Pacific Ocean and Bering Sea. $<$ Bull. Amer. Mus. Nat. Hist., XVI, pp. 459-499, with 10 text figures, Dec. 12, 1902.

Nomenclature; sexual differences in dentition; revision of the North Pacific species (11 species and subspecies are recognized), the following new: (1) Phoca hispida gichigensis, p. 488; (2) Phoca ochotensis macrodens, p. 483; (3) Phoca stejnegeri, p. 485; (4) Phoca richardii pribilofensis; (5) Phoca richardii geronimensis, p. 495.

Phoca nigra Pallas (p. 483 footnote) suggested as apparently available for Callorhinus curilensis (see infra, No. 192). 
1903.

186. Description of a new species of Sigmodon from Ecuador. <Bull. Amer. Mus. Nat. Hist., XIX, pp. 99-100, March 20, 1903.

Sigmodon puna sp. nov.

187. Report on the Mammals Collected in Northeastern Siberia by the Jesup North Pacific Expedition, with Itinerary and Field Notes by N. G. Buxton. $<$ Bull. Amer. Mus. Nat. Hist., XIX, pp. 101-184, 195, 196, May 9, 1903.

Descriptive, critical, and field notes on 35 species, the following new: (1) Citellus buxtoni, p. 139; (2) Citellus stejnegeri, p. 142; (3) Evotomys (Craseomys) latastei, p. 145; (4) Evotomys jochelsoni, p. 148; (5) Lemmus obensis chrysogaster, p. 153; (6) Ochotona kolymensis, p. 154; (7) Lepus gichiganus, p. 155; (8) Vulpes anadyrensis, p. 167; (9) Putorius (Arctogale) pygmæus, p. 176; (10) Erinaceus orientalis, p. 179; (11) Sorex buxtoni, p. 181.

188. Descriptions of new Rodents from Southern Patagonia, with a Note on the Genus Euneomys Coues, and an Addendum to Article [supra, No. 186] on Siberian Mammals. <Bull. Amer. Mus. Nat. Hist., XIX, pp. 185-196, May 9, 1903.

(1) Ctenomys robustus, p. 185; (2) Ctenomys sericeus, p. 187; (3) Ctenomys colburni, p. 188; (4) Oxymycterus microtis, p. 189; (5) Reithrodon cuniculoides obscurus, p. 190, (6) Reithrodon hatcheri, p. 191; (7) Euneomys petersoni, p. 192, spp. et subspp. nov.

Euneomys Coues, a well-founded genus.

189. Mammals collected in Alaska and Northern British Columbia by the Andrew J. Stone Expedition of 1902.<Bull. Amer. Mus. Nat. Hist., XIX, pp. 521567, text figs. 1-9, Oct. 10, 1903.

Annotated list of 28 species, the following new: (1) Citellus stonei, p. 537; (2) Synaptomys (Mictomys) chapmani, p. 555; (3) Synaptomys (Mictomys) andersoni, p. 554; (4) Erethizon epizanthus nigrescens, p. 558; (5) Putorius microtis, p. 563.

Under the mistaken impression that Alce properly dated from Frisch (1775), thus antedating Alce Blumenbach (1799) and Alces Gray (1821), Paralces Allen (1902 - cf. supra, No, 180) is here conceded to be untenable, but later investigation renders it evident that Frisch's work in which Alce was proposed is not to be accepted as nomenclaturally authoritative.

190. List of Mammals collected by J. H. Batty in New Mexico and Durango, with Descriptions of new Species and Subspecies.<Bull. Amer. Mus. Nat. Hist., XIX, pp. 587-612, Nov. 13, 1903.

An annotated list of 34 species, the following new: (1) Odocoileus battyi, p. 591; (2) Eutamias durangæ, p. 594; (3) Citellus (Otospermophilus) grammurus rupestris, p. 595; (4) Peromyscus paulus, p. 598; (5) Peromyscus texanus flaccidus, p. 599; (6) Sigmodon baileyi, p. 601; (7) Reithrodontomys megalotis sestinensis, p. 602; (8) Neotoma intermedia durangæ, p. 602; (9) Perodipus obscurus, p. 603; (10) Lepus (Macrotolagus) texianus micropus, p. 605; (11) Lepus (Macrotolagus) gaillardi battyi, p. 607; (12) Lepus (Sylvilagus) durangæ, p. 609;

(13) Canis impavidus, p. 609; (14) Myotis californicus durangæ, p. 612.

191. A new Deer and a new Lynx from the State of Sinaloa, Mexico. $<$ Bull. Amer. Mus. Nat. Hist., XIX, pp. 613-615, Nov. 14, 1903.

(1) Odocoileus sinaloæ, p. 613; (2) Lynx ruffus escuinapæ, p. 614.

192. Note on Phoca nigra Pallas. <Proc. Biol. Soc. Washington, XVI, p. 49, March 19, 1903.

The name being preoccupied cannot be used in place of Callotaria curilensis Jordan and" Clark, as previously suggested (see supra, No. 185). 
193. Note on Sciurus mollipilosus Audubon and Bachman. <Proc. Biol. Soc. Washington, XVI, p. 126, Sept. 30, 1903.

Defense of the use of mollipilosus in place of the later orarius Bangs.

1904.

194. New forms of the Mountain Goat (Oreamnos). <Bull. Amer. Mus. Nat. Hist., XX, pp. 19-21, text fig. 1-18, Feb. 10, 1904.

(1) Oreamnos montanus columbianus and (2) O. m. missoulæ (p. 20), subspp. nov.

195. Mammals from Southern Mexico and Central and South America. $<$ Bull. Amer. Mus. Nat. Hist., XX, pp. 29-80, Feb. 29, 1904.

Annotated lists from Southern Vera Cruz, Mexico, 19 spp.; Central Costa Rica, 23 spp.; Chiriqui, Republic of Panama, 53 spp. Partial revisions of the genera Tayra, Nasua, and Potos.

New species and subspecies: (1) Lepus (Sylvilagus) russatus, p. 31; (2) Lepus (Sylvilagus) parvulus, p. 34; (3) Tayra barbara irara, p. 36; (4) Akodon irazu, p. 46; (5) Felis carrikeri, p. 47; (6) Nasua narica bullata, p. 48; (7) Nasua narica panamensis, p. 51; (8) Nasua narica yucatanica, p. 52; (9) Nasua narica pallida, p. 53; (10) Sigmodon borucæ chiriquensis, p. 68; (11) Felis mearnsi (nom. nov.), p. 71; (12) Felis panamensis, p. 71; (13) Potos flavus chiriquensis, p. 74; (14) Potos flavus caucensis, p. 75; (15) Potos flavus chapadensis, p. 76; (16) Myotis chiriquensis, p. 77.

196. The External Ear Bone in certain Rodents. <Bull. Amer. Mus. Nat. Hist., XX, pp. 135-138, text fig., April 7, 1904.

External ear bone in Heteromys, here first described and figured.

197. Further Notes on Mammals from Northwestern Durango. <Bull. Amer. Mus. Nat. Hist., XX, pp. 205-210, May 28, 1904.

An annotated list of 17 species, the following new: (1) Sciurus aberti phæurus, p. 205; (2) Sciurus aberti barberi, p. 207; (3) Eutamias canescens, p. 208.

198. New Bats from Tropical America, with note on Species of Otopterus. $<$ Bull. Amer. Mus. Nat. Hist., XX, pp. 227-237, June 29, 1904.

Spp. et subspp. nov.: (1) Molossus coibensis, p. 227; (2) Molossus bondæ, p. 228; (3) Promops barbatus, p. 228; (4) Dermonotus suapurensis, p. 229; (5) Lonchophylla thomasi, p. 230; (6) Artibeus rusbyi, p. 230; (7) Artibeus insularis, p. 231; (8) Artibeus yucatanicus, p. 232; (9) Phyllostoma hastatus panamensis, p. 233; (10) Phyllostoma hastatus cauræ, p. 234.

Two species of Otopterus in Mexico - O. bocourtianus (Dobson) and O. mexicanus (Saussure).

199. Mammals Collected in Alaska by the Andrew J. Stone Expedition of 1903. <Bull. Amer. Mus. Nat. Hist., XX, pp. 273-292, fig. 1-19, Sept. 8, 1904.

An annotated list, with many measurements, of 28 species.

200. A new Sheep from Kamchatka. <Bull. Amer. Mus. Nat. Hist., XX, pp. 293298, fig. 1-6, Sept. 8, 1904.

Ovis storcki, sp. nov.

201. New Mammals from Venezuela and Colombia.<Bull. Amer. Mus. Nat. Hist., XX, pp. 327-335, Oct. 8, 1904.

Spp. et subspp. nov.: (1) Peramys brevicaudatus dorsalis, p. 327; (2) Oryzomys tenuipes, p. 328; (3) Akodon meridensis, p. 329; (4) Holochilus venezuelensis, p. 330; (5) Felis maripensis, p. 331; (6) Felis sanctæmartæ, p. 332; (7) Procyon proteus, p. 333; (8) Nasua phæocephala. p. 334 . 
202. List of Mammals from Venezuela collected by Mr. Samuel M. Klages. $<$ Bull. Amer. Mus. Nat. Hist., XX, pp. 337-345, Oct. S, 1904.

An annotated list of 46 species.

203. A Fossil Porcupine from Arizona. <Bull. Amer. Mus. Nat. Hist., XX, pp. 383384, Oct. 15, 1904.

Erethizon godfreyi, sp. nov.

204. The Tamandua Anteaters. <Bull. Amer. Mus. Nat. Hist., XX, pp. 385-398, fig. 1-4, Oct. 29, 1904.

A review of the group, with respect to external and cranial characters. Subspp. nov.: (1) Tamandua tetradactyla chapadensis, p. 392; (2) T. t. instabilis, p. 392; (3) T. t. tenuirostris, p. 394; (4) T. t. chiriquensis, p. 395.

205. Report on Mammals from the District of Santa Marta, Colombia, collected by Mr. Herbert H. Smith, with Field Notes by Mr. Smith.<Bull. Amer. Mus. Nat. Hist., XX, pp. 407-468, fig. 1-4, Nov. 28, 1904.

An annotated list of 78 species, the following new: (1) Coendou sanctæmartæ, p. 441; (2) Lutra colombiana, p. 452; (3) Alouatta seniculus rubicunda, p. 458; (4) Alouatta seniculus caucensis, p. 462.

Urocyon aquilus Bangs not referable to Urocyon.

206. Palmer's 'Index Generum Mammalium.'<Science, N. S., XIX, pp. 498-501, March 25, 1904.

A review of this notable work (N. Amer. Fauna, No. 23, Jan. 1904.)

1905.

207. Mammalia of Southern Patagonia. Reports of the Princeton University Expeditions to Patagonia, 1896-1899, Vol. III, 1905, Part I, pp. 1-120, pll. i-xxix.

Detailed treatment of 55 species, with special reference to nomenclature, that of the genera as well as the species discussed historically; full tables of references under the genera and species, and an annotated bibliography (pp. 192-210) of 65 titles.

Eunothocyon, gen. nov., p. 153 (in text); Carcinocyon, gen. nov., p. 153 (in text; Ctenomys osgoodi, nom. nov., to replace $C$. robustus Allen, preoccupied, p. 191; Canis sclateri nom. nov. (p. 153) to replace Canis microtis Sclater, preoccupied.

Species figured: Zaedyus ciliatus, pll. i-iii (animal, skeleton, and three skulls); Kerodon australis and Ctenomys osgoodi, pl. vii (skulls); Ctenomys sericeus and C. colburni, pl. viii (skulls); Eligmodontia, Oryzomys and Oxymycterus, pll. ix and x (skulls and dentition of various species); Akodon, pll. xi and xii (skulls and dentition of 6 species); Phyllotis, Euneomys, and Reithrodon, pll. xiii and xiv (skulls and dentition); Arctocephalus australis and A. philippii, pll. xv-xvii (skulls, three views of each); Arctocephalus townsendi pll. $\mathrm{xviii-xx}$ (skull, three views); Otaria byronia, pl. xxi (skeleton); Conepatus humboldti, pl. xxii (skulls and dentition); Cerdocyon griseus, pl. xxiii (skull, three views); Lynchailurus pajeros crucina, pl. xxiv (skull and dentition); Puma pearsoni, pll. xxv and xxvi (colored figures of animal, red and gray phases); Puma pearsoni, pll. xxvii-xxix (three views of skull).

208. The Andrew J. Stone Explorations in Arctic and Subarctic America. 4to, pp. i-xvi, 1-38, with 55 half-tone illustrations in text. American Museum of Natural History, 1905. Edition limited to 100 numbered copies. (Anonymous.)

The illustrations, from photographs, relate mostly to mammals, as does the greater part of the text. 
209. Mammals from Beaver County, Utah, collected by the [Brooklyn Institute] Museum Expedition of 1904.<Science Bulletin Mus. Brooklyn Inst. Arts and Sciences, I, No. 6, pp. 117-122, March 31, 1905.

Annotated list of 16 species, the following new: (1) Eutamias lectus, p. 117; (2) Eutamias adsitus, p. 118; (3) Cynomys parvidens, p. 119; (4) Marmota engelhardti, p. 120; (5) Ochotona cinnamomea, p. 121.

1906.

210. Mammals from the States of Sinaloa and Jalisco, Mexico, collected by J. H. Batty during 1904 and 1905.<Bull. Amer. Mus. Nat. Hist., XXII, pp. 191-262, pll. xx-xxxiii, and 3 text figures, July 25, 1906.

I. Mammals from Southern Sinaloa, pp. 192-237, 41 species; II. Mammals from the State of Jalisco, pp. 237-262, 60 species. Extended field notes, much critical comment, and many measurements, in text or tabulated. The deer, peccaries, and nasuas treated at length, with illustrations, in the case of Nasua with relation to sex and age; pathological conditions in skulls of Tayassu treated at length.

Spp. et subspp nov.: (1) Heteromys pictus escuinapæ, p. 211; (2)'Molossus sinalox, p. 236; (3) Sciurus poliopus tepicanus, p. 243; (3) Sigmodon vulcani, p. 247; (4) Heteromys: jaliscensis, p. 251.

211. Mammals from the Island of Hainan, China. <Bull. Amer. Mus. Nat. Hist., XXII, pp. 463-490, pl. xix, Dec. 17, 1906.

An annotated list of 41 species, the following new: (1) Manis pusilla, p. 465; (2) Atherurus hainanus, p. 470; (3) Ratufa gigantea hainana, p. 472; (4) Funambulus rindonensis, p. 472; (5) Sciurus erythræus insularis, p. 473; (6) Tamiops (gen. nov.) macclellandi hainanus, p. 476; (7) Tamiops macclellandi riudoni, p. 477; (8) Tupaia modesta, p. 481; (9) Rhinolophus: hainanus, p. 482; (10) Hipposideros poutensis, p. 483; (11) Scotophilus kuhlii insularis, p. 485; (12) Scotophilus castaneus consobrinus, p. 485; (13) Pipistrellus portensis, p. 487.

212. The proper name of the Mexican Tamandua.<Proc. Biol. Soc. Washington, XIX, p. 200, Dec. 31, 1906.

The specific name mexicanus Saussure, 1860, should replace tenuirostris Allen, 1904.

213. Vertebrata of the Land; Birds and Mammals.<Science, N. S., XXIII, pp. 317-319, Feb. 28, 1906.

In report of a discussion before the American Society of Naturalists at Philadelphia, Dec. 27, 1895, on 'The Origin and Relations of the Floras and Faunas of the Antarctic and Adjacent Regions.'

1907.

214. The Families and Genera of Bats. <Amer. Nat., XLI, pp. 671-672, Oct. 1907.

Review of Gerrit S. Miller's work of this title (Bull. U. S. Nat. Mus., No. 57, June 29, 1907).

1908.

215. The North Atlantic Right Whale and its near Allies. <Bull. Amer. Mus. Nat. Hist., XXIV, pp. 277-329, pll. xix-xxiv, and 1 text figure, April 8, 1908.

History, relationships, nomenclature, geographical distribution, and external and osteological characters of Eubalæna glacialis (Bonnaterre).

216. The Peary Caribou (Rangifer pearyi Allen).<Bull. Amer. Mus. Nat. Hist., XXIV, pp. 487-493, fig. 1-12, May 22, 1908.

Detailed description, with measurements and figures of skulls and antlers, and comparison with allied forms. 
217. Notes on Solenodon paradoxurus Brandt. $<$ Bull. Amer. Mus. Nat. Hist., XXIV, pp. 305-517, pll. xxviii-xxxiii, and fig. 1-9, June 8, 1908.

External and cranial characters described and figured, including a young skull with milk dentition, and comparison with S. cubanus.

218. Mammalogical Notes.-I-VI.<Bull. Amer. Mus. Nat. Hist., XXIV, pp. 575-589, fig. 1-4, Sept. 11, 1908.

(1) Concrescence in premolars of a bat (Artibeus quadrivittatus); (2) bats from the Island of San Domingo (Ardops haitiensis and Molossus verrilli, spp. nov., p. 581); (3) note on the type of the genus Sciuropterus; (4) note on the type locality of Rangifer arctica (Richardson); (5) northward extension of range of Coyotes; (6) the generic name Galera Browne.

219. Mammals from Nicaragua. < Bull. Amer. Mus. Nat. Hist., XXIV, pp. 647-670, text figs, 1-12, Oct. 13, 1908.

Annotated list of 59 species. Gen. nov., Hoplomys, p. 649; spp. et subspp. nov.: (1) Lepus gabbi tumacus, p. 649; (2) Hoplomys truei, p. 650; (3) Heteromys vulcani, p. 652; (4) Heteromys fuscatus, p. 652; (5) Neotoma chrysomelas, p. 653; (6) Oryzomys alfaroi incertus, p. 655 ; (7) Oryzomys ochraceus, p. 655; (8) Oryzomys carrikeri, p. 656; (9) Sigmodon hispidus griseus, p. 657; (10) Ototylomys fumeus, p. 658; (11) Peromyscus nicaraguæ, p. 658; (12) Sciurus deppei matagalpæ, p. 660; (13) Lutra latidens, p. 660; (14) Tayra barbara inserta, p. 662 ; (15) Bassaricyon richardsoni, p. 662; (16) Blarina olivaceus, p. 669; (17) Artibeus jamaicensis richardsoni, p. 669; (18) Alouatta palliata matagalpæ, p. 670.

1909.

220. Mammals from British East Africa, collected by the Tjädor Expedition of 1906. <Bull. Amer. Mus. Nat. Hist., XXVI, pp. 147-175, fig. 1-10, March $19,1901$.

Annotated list of 56 species. Spp. et subspp. nov.: (1) Tragelaphus tjaderi, p. 148; (2) Madoqua langi, p. 153; (3) Arvicanthis nairobæ, p. 168; (4) Mus kijabius, p. 169; (5) Crocidura kijabæ, p. 173.

221. The White Bear of Southwestern British Columbia <Bull. Amer. Mus. Nat. Hist., XXVI, pp. 233-238, figs. 1-4, April 17, 1909.

External and cranial characters of Ursus kermodei Hornaday.

222. Further Notes on Mammals from the Island of Hainan, China. <Bull. Amer. Mus. Nat. Hist., XXVI, pp. 239-242, April 17, 1909.

Notes on 13 species, 2 new for the island. (1) Paradoxurus (Paguma) larvatus hainanus and (2) Mungos rubrifrons, p. 240, sp. et subsp. nov.

223. Mammals from Shen-si Province, China. <Bull. Amer. Mus. Nat. Hist., XXVI, pp. 425-430, Oct. 21, 1909.

Annotated list of 15 species. Spp. nov.: (1) Myotalpa rufescens, p. 428; (2) Sciurolamias owstoni, p. 428; (3) Eutamias albogularis, p. 429.

224. Osgood's Revision of the Mice of the Genus Peromyscus. < Amer. Nat., XLIII, pp. 633-639, Oct., 1909.

Review of W. H. Osgood's paper of this title (N. Amer. Fauna, No. 28, April 17, 1909), in part historical of the subject.

225. 'Life Histories of Northern Animals.' <Science, N. S., XXX, No. 782, pp. 924-927, Dec. 24, 1999.

Review of Ernest Thompson Seton's work of this title, 2 vols, roy. 8vo., New York, Charles Scribner's Sons, 1909. 
1910.

226. The Black Bear of Labrador.<Bull. Amer. Mus. Nat. Hist., XXVIII, pp. 1-6, Jan. 5, 1910.

Ursus americanus sornborgeri Bangs, not tenable. Ursus americanus kenaiensis (p. 6), subsp. nov.

227. Mammals from the Athabasca-Mackenzie Region of Canada.<Bull. Amer. Mus. Nat. Hist., XXVIII, pp. 7-11, Jan. 5, 1910.

Annotated list of 25 species.

228. Mammals from Palawan Island, Philippine Islands. <Bull. Amer. Mus. Nat. Hist., XXVIII, pp. 13-17, Jan. 5, 1910.

Annotated list of 13 species, the following new: (1) Mus luteiventris, p. 14; (2) Arctictis whitei, p. 15; (3) Mungos palawanus, p. 17.

229. Nelson's Monograph of the North American Leporidæ. <Amer. Nat., XLIV, pp. 57-63, Jan., 1910.

Review of 'The Rabbits of North America,' by E. W. Nelson (N. Amer. Fauna, No. 29, August 31, 1909). Lepus aquaticus littoralis Nelson shown to be a synonym of Lepus aquaticus aquaticus.

230. Seton's 'Life Histories of North American Animals.' <Amer. Nat., XLIV, pp. 124-127, Feb., 1910.

Review of Ernest Thompson Seton's work of this title.

231. Additional Mammals from Nicaragua. < Bull. Amer. Mus. Nat. Hist., XXVIII, pp. 87-115, April 30, 1910.

Annotated list of 82 species represented by specimens in the American Museum of Natural History, and 50 additional species on the basis of previous records. Spp. nov.: (1) Macrogeomys matagalpæ, p. 97; (2) Oryzomys richardsoni, p. 99; (3) O. nicaraguæ, p. 100; (4) Conepatus nicaraguæ, p. 106 . Ursus americanus perniger, p. 115, nom. nov. for $U$. $a$. kenaiensis, preoccupied.

232. Mammals from the Caura district of Venezuela, with description of a new species of Chrotopterus. <Bull. Amer. Mus. Nat. Hist., XXVIII, pp. 145149, May 27, 1910.

Annotated list of 14 species. Chrotopterus carrikeri (p. 147), sp. nov.

233. The Mammals of Colorado.<Science, N. S., XXXII, No. 814, pp. 178-179, Aug. 5, 1910.

Review of Edward Royal Warren's book of this title (16 mo, New York and London, 1910).

1911.

234. Mammals from Venezuela collected by Mr. M. A. Carriker, Jr., 1909-1911. <Bull. Amer. Mus. Nat. Hist., XXX, p. 239-273, Dec. 2, 1911.

Annotated list of 66 spp. Spp. et subspp. nov.: (1) Cavia porcella venezuelæ, p. 250; (2) Loncheres carrikeri, p. 251; (3) Urocyon cinereoargentea venezuelæ, p. 259; (4) Chilonycteris rubiginosa fusca, p. 262.

235. Mammals collected in the Dutch East Indies by Mr. Roy C. Andrews, on the cruise of the 'Albatross' in 1909. <Bull. Amer. Mus. Nat. Hist., XXX, pp. 335-339, Dec. 21, 1911.

Annotated list of 16 species. Spp. nov.: (1) Mus andrewsi, p. 336; (2) M. buruensis, p. 336; Sciurus beebei, p. 338; (4) Tamiops sauteri, p. 339. 
236. The Okapi.<Amer. Mus. Journ., XI, No. 2, March, 1911, pp. 73-75.

A general account of the Okapi with reference to specimens received from the Museum's Congo Expedition.

237. The Habitat Groups of Mammals and Birds in the American Museum of Natural History. <Amer. Mus. Journ., XI, No. 7, pp. 248-249, Nov. 1911.

1912

238. Sheldon's 'The Wilderness of the Upper Yukon.' <Science, N. S., XXXV, No. 890, pp. 105-106, Jan. 19, 1912.

Review of Charles Sheldon's 'The Wilderness of the Upper Yukon: A Hunter's Explorations for Wild Sheep in Sub-Arctic Mountains.'

239. Historical and Nomenclatorial Notes on North American Sheep. $<$ Bull. Amer. Mus. Nat. Hist., XXXI, pp. 1-29, text figs. 1-4, March 4, 1912.

McGillivray's original account of his discovery of Wild Sheep in Canada in 1800, and copy of his original figure (pp. 2-7); E. Geoffroy's 'Belier de Montagne' (p. 8); Ovis cervina Demarest and Ovis canadensis Shaw (pp. 9-11); collation of Shaw and Nodder's 'Naturalist's Miscellany,' with reference to the date of Ovis canadensis Shaw (pp. 11-15); other early references to the Mountain Sheep of North America (pp. 15-17); the Taye of "California," with a copy of Venega's figure (pp. 17-20); synonymic list of North American Sheep, with their type localities and ranges (pp. 22-29). Eleven forms recognized, including Ovis californianus Douglas.

240. Mammals from Western Colombia.<Bull. Amer. Mus. Nat. Hist., XXXI, pp. 71-95, April 19, 1912.

Annotated list of 55 spp. Spp. et subspp. nov.: (1) Sylvilagus (Tapeti) fulvescens, p. 75 ; (2) Heteromys lomitensis, p. 77; (3) Reithrodontomys milleri, p. 77; (4) Rhipidomys mollissimus, p. 78; (5) R. similis, p. 79; (6) R. cocalensis, p. 79; (7) Thomasomys cinereiventer, p. 80; (8) T. popayanus, p. 81; (9) Neacomys pusillus, p. 81; (10) Oryzomys palmiræ, p. 83; (11) O. pectoralis, p. 83; (12) O. (Oligoryzomys) munchiquensis, p. 85; (13) O. (O.) fulvirostris, p. 86; (14) O. (Melanomys) obscurior affinis, p. 88; (15) Epeomys fuscatus, p. 89; (16) Microxus affinis, p. 89; (17) Sciurus milleri, p. 91; (18) Blarina (Cryptotis) squamipes, p. 93.

241. A new Pika from Colorado. <Bull. Amer. Mus. Nat. Hist., XXXI, pp. 103-104, Sept. 2, 1912.

Ochotona figginsi, p. 103.

242. The probable recent extinction of the Muskox in Alaska. <Science, N. S., XXXVI, No. 934, pp. 720-722, Nov. 22, 1912.

Evidence that Muskoxen lived in Alaska "as recently as fif ty to sixty years ago."

243. Zoölogy of the Stephánsson-Anderson [Arctic] Expedition - a preliminary Estimate.<Amer. Mus. Journ., XII, p. 237, Nov., 1912.

244. Miller's 'List of North American Land Mammals in the United States National Museum.' < Science, N. S., XXXVII, No. 951, pp. 453-454, March 21, 1913.

Review of the work (Bull. 79, U. S. Nat. Mus., Dec. 31, 1912).

1913.

245. Mammals collected in Korea.<Bull. Amer. Mus. Nat. Hist., XXXII, pp. 427-436, Sept. 2, 1913. (With Roy C. Andrews.)

Annotated list of 19 spp., with field notes by Mr. Andrews. Spp. nov.: (1) Ochotona (Pika) coreanus, p. 429; (2) Meles melanogenys, 433. 
246. New Mammals from Colombia and Ecuador. <Bull. Amer. Mus. Nat. Hist., XXXII, pp. 469-484, text figs. 1-18, Sept. 25, 1913.

Spp. et subspp. nov.: (1) Cholopus florenciæ, p. 469; (2) C. agustinus, p. 470; (3) C. andinus, p. 472; (4) C. capitalis, p. 472; (5) Tayassu niger, p. 476; (6) Sylvilagus (Tapeti) salentus, p. 476; (7) Myoprocta milleri, p. 477; (8) Coendu quichua richardsoni, p. 478; (9) Proechimys o'connelli, p. 479; (10) Sigmodon chonensis, p. 479; (11) Akodon tolimæ, p. 480; (12) Potos flavus tolimensis, p. 481; (13) Nasua olivacea lagunetæ, p. 483; (14) Tayra barbara senilis, p. 484.

247. Revision of the Melanomys Group of American Muridæ. <Bull. Amer. Mus. Nat. Hist., XXXII, p. 535-555, pl. lxviii, Nov. 17, 1913.

14 species and subspecies, the following new: (1) Melanomys caliginosus oroensis, p. 538; (2) M. affinis monticola, p. 540; (3) M. phæopus vallicola, p. 544; (4) M. phæopus tolimensis, p. 545 ; (5) M. lomitensis, p. 545; (6) M. buenavistæ, p. 547.

248. New South American Muridæ.<Bull. Amer. Mus. Nat. Hist., XXXII, pp. 597-604, Dec. 3, 1913.

Spp. et subspp. nov.: (1) Oryzomys helvolus, p. 597; (2) O. o'connelli, p. 597; (3) O. vincencianus, p. 598; (4) O. incertus, p. 598; (5) Zygodontomys griseus, p. 599; (6) Z. fraterculus, p. 599; (7) Akodon chapmani, p. 600; (8) Rhipidomys quindianus, p. 600; (9) $R$ caucensis, p. 601; (10) R. venezuelæ yuruanus, p. 601; (11) R. mitleri, p. 602; (12) Ecomys mincæ, p. 603; (13) E. caicaræ, p. 603.

249. Catalogue of Mammals of Western Europe.<Science, N. S., XXXVIII, No. 970, pp. 159-162, Aug. 1, 1913.

Review of Gerrit S. Miller's work of this title (8vo, British Museum, 1912).

250. Ontogenetic and other Variations in Muskoxen, with a systematic Review of the Muskox Group, recent and extinct.<Mem. Amer. Mus. Nat. Hist., New Series, I, Pt. 4, 1913, pp. 101-226, pll. xi-xviii, 1 map, and 45 text figs., March, 1913.

Ontogenesis of the horns, teeth, skull and pelage, pp. 107-143; individual differentiation as indicated by the skull, pp. 143-157; systematic review, including historical summary, pp. 157-160; geographic distribution, past and present, pp. 160-164; classification and relationship, 164-171; Ovibos, characters, alleged species and subspecies, pp. 171-179; geographic variation, pp. 179-180; synopsis of species and subspecies, pp. 180-182; systematic description, habits, and distribution: Ovibos moschatus moschatus, pp. 183-189; O. m. niphœcus, pp. 189-191; O. m. wardi, pp. 191-201; O. yukonensis (extinct), pp. 201-203; O. pallantis (extinct), pp. 203-205; extermination, pp. 205-207; Muskoxen in Zoölogical Gardens, pp. 207-208; Bootherium, pp. 209-213; Symbos, pp. 213-215; Liops, p. 216; bibliography, pp. 221-226.

Plates $\mathrm{xi}-\mathrm{xv}$, O. m. wardi as follows: pl. xi, horncores; pl. xii, transverse sections of horncores; pl. xiii, longitudinal sections of horncores; pl. xiv, sections of horncores; pl. xv, maxillary toothrow at different ages; pl. xvi, mandibular toothrow at different ages. Plates xvii and xviii, skull of Symbos cavifrons.

Text figures 1-26, skulls and dentition of $O$. m. wardi from fotal age to senescence; text fig. 27, map of distribution, present and recent, of Muskoxen in North America and Greenland; text figs. 28-31, skulls of $O$. m. moschatus and $O . m$. wardi; text figs. 32-36, mounted specimens of same; text figs. 38-44, photographs of calves of $O$. m. wardi in New York Zoölogical Park; text fig. 45, type skull of Bootherium bombifrons.

251. Shall the Walrus become Extinct?<Amer. Mus. Journ., XIII, pp. 38-42, Jan., 1913. With illustrations.

Comment on its unrestricted destruction and need of international restriction for its preservation. 


\section{4.}

252. Review of the Genus Microsciurus. <Bull. Amer. Mus. Nat. Hist., XXXIII, pp. 145-165, Feb. 26, 1914.

19 species and subspecies recognized. Spp. nov.: (1) Microsciurus rubrirostris, p. 163; (2) M. florenciæ, p. 164.

253. Two new Mammals from Ecuador.<Bull. Amer. Mus. Nat. Hist., XXXIII, pp. 199-200, Feb. 28, 1914.

(1) Sylvilagus daulensis, p. 199; (2) Thomasomys aureus altorum, p. 200.

254. Mammals from British East Africa, collected on the Third African Expedition of the American Museum by William S. Rainsford. <Bull. Amer. Mus. Nat. Hist., XXXIII, pp. 337-344, June 18, 1914.

Annotated list of 40 species.

255. New South American Bats and a new Octodent.<Bull. Amer. Mus. Nat. Hist., XXXIII, pp. 381-389, pl. xxviii, July 9, 1914.

Spp. et subspp. nov.: (1) Amorphochilus schnablii osgoodi, p. 381; (2) Eptesicus andinus, p. 382; (3) Dasypterus ega punensis, p. 382; (4) Myotis ruber keaysi, p. 383; (5) M. punensis, p. 383; (6) M. bondæ, p. 384; (7) M. maripensis, p. 385; (8) M. esmeraldæ, p. 385; (9) M. caucensis, p. 386; (10) Nyctinomus æquatorialis, p. 386; (11) Mormopterus peruanus, p. 387; (12) Thrinacodus apolinari, p. 387, pl. xxxviii, skull, with skull of Dactylomys dactylinus for comparison.

256. New South American Sciuridæ. <Bull. Amer. Mus. Nat. Hist., XXXIII, pp. 585-597, fig. 1-2, Oct. 8, 1914.

Notosciurus gen. nov., p. 585; spp. et subspp. nov.: (1) N. rhoadsi, p. 585, text figs. 1-2; (2) Guerlinguetus pucheranii salentensis, p. 587; (3) G. hoffmanni quindianus, 587 ; (4) G. hoffmanni manavi, p. 589; (5) G. griseimembra, p. 589; (6) G. candelensis, p. 590; (7) Sciurus gerrardi salaquensis, p. 592; (8) S. gerrardi cucutæ, p. 592; (9) S. saltuensis magdalenæ, 594; (10) S. duida, p. 594; (11) S. igniventris zamoræ, 594; (12) S. langsdorffii urucumus, p. 595; (13) S. langsdorffii steinbachi, p. 596; (14) S. stramineus zarumæ, 597.

257. New South American Monkeys. <Bull. Amer. Mus. Nat. Hist., XXXIII, pp. 647-655, Dec. 14, 1914.

Spp. et subspp. nov.: (1) Callicebus lugens duida, p. 647; (2) Alouatta seniculus bogotensis, p. 648; (3) A. seniculus caquetensis, p. 650; (4) Pithecia milleri, p. 650; (5) Cacajao roosevelti, p. 651; (6) Ateles longimembris, p. 65; (7) A. robustus, p. 652; (8) Cebus apella brunneus, 653; (9) C. æquatorialis, p. 654 .

258. The Generic Names Speothos and Icticyon.<Proc. Biol. Soc. Washington, XXVII, p. 147, July 10, 1914.

Both genera tenable, not synonyms as held by some authors.

258a. Individual Variation in Muskoxen. $<\mathrm{IX}^{\mathrm{e}}$ Congrés International de Zoologie tenu à Monaco, 1913, pp. 210-215. Separates received in June, 1914.

With reference to the bones of the skull.

1915.

259. Review of the South American Sciuridæ. <Bull. Amer. Mus. Nat. Hist., XXXIV, pp. 147-309, pll. i-xiv, and 25 text figs., May 17, 1915.

Historical outline, pp. 151-158; general considerations, pp. 158-168; genera and subgenera of American squirrels, pp. 169-186; systematic review of the South American squirrels, 
pp. 187-296; geographic distribution and interrelationships of South American squirrels, pp. $297-307$.

Gen. nov.: (1) Leptosciurus, p. 199; (2) Mesosciurus, p. 212; (3) Hadrosciurus, p. 265; (4) Urosciurus, p. 267; (5) Simosciurus, p. 280; (6) Histriosciurus (subgen. nov.), p. 236. Subspp. nov.: (1) Guerlinguetus æstuans venustus, p. 260; (2) Mesosciurus gerrardi baudensis, p. 308; (3) M. gerrardi valdivia, p. 309.

Plates i-v, skulls of North American species; vi, maxillary teeth of same; vii-xii, skulls of South American species; xiii and xiv, maxillary teeth of same; text figs. 1-16, skins of South American species, to show relative size; text figs. 17-19, skull of Syntheosciurus brochus, p. 176; text figs. 20-21, hind foot of Notosciurus and Mesosciurus, p. 211; text figs. 22-25, distribution maps of genera.

260. Notes on American Deer of the Genus Mazama.<Bull. Amer. Mus. Nat. Hist., XXXIV, pp. 521-553.

24 forms recognized, the following new: (1) Mazama trinitatis, p. 532; (2) M. americana tumatumari, p. 536; (3) M. americana juruana, p. 537; (4) M. gualea, p. 545; (5) M. fuscata, p. 545; (6) M. zamora, p. 546; (7) M. murelia, p. 547; (8) M. cita sanctæmartæ, p. 550.

261. New South American Mammals. <Bull. Amer. Mus. Nat. Hist., XXXIV, pp. 625-634, Dec. 30, 1915.

(1) Dasyprocta fuliginosa candelensis, p. 625; (2) Dasyprocta variegata zamoræ, p. 627; (3) Dasyprocta variegata chocoensis, p. 627; (4) Dasyprocta variegata urucuma, p. 634; (5) Proechimys kermiti, p. 629; (6) Oryzomys mureliæ (nom. nov., to replace O. incertus Allen, 1913, preoccupied), p. 630; (7) Procyon (Euprocyon) æquatorialis, p. 630; (8) Margay tigrina elenæ, p. 631; (9) Margay caucensis, p. 631; (10) Oncoides pardalis tumatumari, p. 632; (11) Eptesicus chapmani, p. 632.

262. Convenience versus Fitness. <Science, N. S., XLII, No. 1084, pp. 492-494, Oct. 8, 1915.

On the function of the genus in classification, in reply to objectors who oppose subdivision of the "good old genera" of fifty years ago. Certain groups of mammals cited in illustration.

1916.

263. The proper Generic Name of the Macaques.<Bull. Amer. Mus. Nat. Hist., XXXV, pp. 49-52, Feb. 21, 1916.

Silenus Goldfuss, 1820. The subgeneric names of the macaques and their near allies also considered. Comparison (in parallel columns) of the generic and subgeneric names of macaques employed by Elliot (Primates, 1913) with those here adopted.

264. New South American Mammals. <Bull. Amer. Mus. Nat. Hist., XXXV, pp. 83-87, April 28, 1916.

(1) Metachirus nudicaudatus antioquiæ, p. 83; (2) Tamandua tetradactyla punensis, p. 83; (3) Sylvilagus boylei, p. 84; (4) Cavia (Cavia) anolaimæ, p. 85; (6) Glossophaga apolinari, p. 86; (7) Saimiri caquetensis, p. 87.

265. The Neotropical Weasels. <Bull. Amer. Mus. Nat. Hist., XXXV, pp. 89-111, April 26, 1916.

Historical résumé, pp. 90-91; color variations in the Mustela tropicalis group, pp. 91-98; the status of Mustela affinis Gray, pp. 98-99; systematic review of the species and subspecies, pp. $99-111$.

8 forms recognized -6 species and 2 additional subspecies. Mustela tropicalis nicaraguæ, p. 100, subsp. nov.

266. List of Mammals collected for the American Museum in Ecuador by William B. Richardson, 1912-1913. <Bull. Amer. Mus. Nat. Hist., XXXV, pp. 113125, May 11, 1916.

Annotated list of 70 species and subspecies, with locality records, etc. 
267. List of Mammals collected in Colombia by the American Museum of Natural History Expeditions, 1910-1915.<Bull. Amer. Mus. Nat. Hist., XXXV, pp. 191-238, May 31, 1916.

Annotated list of 185 species and subspecies, with locality records, and technical comment, particularly on some of the Muridæ, Carnivores and Primates. Several extralimital Primates included for purpose of record and comment. Alouatta seniculus group, pp. 228-231.

268. New Mammals collected on the Roosevelt Brazilian Expedition. $<$ Bull. Amer. Mus. Nat. Hist., XXXV, pp. 523-530, July 24, 1916.

Species et subspp. nov.: (1) Proechimys boimensis, p. 523; (2) Ecomys milleri, p. 523; (3) E. florenciæ, p. 524; (4) E. emiliæ, p. 525; (5) Oryzomys (Oligoryzomys) microtis, p. 525; (6) O. (O.) utiaritensis, p. 527; (7) O. (O.) mattogrossæ, p. 528; (8) Zygodontomys tapirapoanus, p. 528; (9) Zygodontomys tapirapoanus, p. 528; (10) Molossus cherriei, p. 529; (11) Molossus daulensis, p. 530.

269. Mammals collected on the Roosevelt Brazilian Expedition, with Field Notes by Leo E. Miller. <Bull. Amer. Mus. Nat. Hist., XXXV, pp. 559-610, Aug. 9, 1916.

Introduction, pp. 559-562; systematic list, 97 species and subspecies, pp. 562-588, with much technical comment; field notes by Leo E. Miller, on 53 species, pp. 589-610.

Tapirus terrestris guianiæ (p. 566), subsp. nov.

270. An Extinct Octodont from the Island of Porto Rico, West Indies. $<$ Ann. New York Acad. Sci., XXVII, pp. 17-22, pll. i-v, Jan. 25, 1916.

Isolobodon portoricensis (gen. et sp. nov.), p. 19.

Note.-The above list of titles ends with August, 1916. They are numbered $1-270$, plus $117 a$ and $258 a$. No. 32 is an inadvertent duplication of No.26. Actual number of titles, 271.

Families, Superfamilies, Subfamilies, Genera and Subgenera, and Species and Subspecies, Described as New or Renamed. ${ }^{1}$

Higher Groups.

Oulophocince, ${ }^{2}$ Bull. Mus. Comp. Zoöl., II, 1870, p. 44.

Trichiphocince, ${ }^{2}$ ibid., p. 44.

Castoroidida, Monographs N. Amer. Rodentia (Rep. U. S. Geolog. Surv. Terr. (Hayden), XI, 1877, p. 419.)

Odobcenidae, Hist. N. Amer. Pinnipeds, 1880, pp. 3, 5.

Gressigrada, ibid., p. $3=$ Odobænidæ + Otariidæ.

Reptigrada, ibid., p. $4=$ Phocidæ.

\section{Genera and Subgenera.}

Bassaricyon, Proc. Acad. Nat. Sci. Philadelphia, 1876, pp. 20-23, pl. i. Type, Bassaricyon gabbi, sp. nov.

Ictidomys, Monographs N. Amer. Rodentia, p. 821, August, 1877. Type, Spermophilus tridecemlineatus Mitchell.

Pachycyon, Mem. Mus. Comp. Zoöl., X, No. 2, pp. 4-8, pll. i-iii, Dec., 1885. Type, Pachycyon robustus, sp. nov. Extinct.

1 Arranged chronologically.

${ }^{2}$ Tentatively proposed as subfamilies of the Otariidæ and subsequently abandoned. 
Microsciurus (subgen. of Sciurus), Bull. Am. Mus. Nat. Hist., VII, p. 333, Nov. 8, 1895. Type, Sciurus (M.) alfaroi.

Zygodontomys, Bull. Am. Mus. Nat. Hist., IX, p. 38, March 11, 1897. Type, Oryzomys cherriei Allen.

Sigmodontomys, Bull. Am. Mus. Nat. Hist., IX, p. 38, March 11, 1897. Type, S. alfari, sp. nov. (= Nectomys.)

Proechimys, Bull. Am. Mus. Nat. Hist., XII, p. 264, Dec. 26, 1899. Type, Echimys trinitatis Allen and Chapman.

Caluromys, Bull. Am. Mus. Nat. Hist., XIII, p. 189, Oct. 12, 1900. Type, C.alstoni.

To replace Philander Brisson, 1762, considered as properly a synonym of Didelphis Linné, 1758. Under the principle of tautonymy Philander later became reinstated for this group, with Didelphis philander Linné as type.

Paralces, Bull. Am. Mus. Nat. Hist., XVI, p. 160, July 1, $1902 . \quad$ Type, Cervus alces.

A substitute name for Alces Gray, 1821, preoccupied by Alce Blumenbach, 1799, type Alce gigantea Blumenbach = Megaceros hibernicus Owen, 1844.

Eunothocyon, Mamm. Patagonia, in Princeton Univ. Exped. Patagonia, III, pt. i, 1905, p. 152. Type, Canis sladeni Thomas.

Carcinocyon, ibid., p. 153. Type, Canis thous Linné. (Cerdocyon H. Smith, type Canis azarce Wied, apud Thomas.)

Tamiops, Bull. Am. Mus. Nat. Hist., XXII, p. 477, July 25, 1906. Type, Tamiops macclellandi riudoni, subsp. nov.

Hoplomys, Bull. Am. Mus. Nat. Hist., XXIV, p. 650, Sept. 11, 1908. Type, Hoplomys truei sp. nov.

Notosciurus, Bull. Am. Mus. Nat. Hist., XXXIII, p. 585, Oct. 8, 1914 . Type, Notosciurus rhoadsi sp. nov.

Leptosciurus, Bull. Amer. Mus. Nat. Hist., XXXIV, p. 199, May 17, 1915. Type, Macroxus pucheranii Fitzinger $=$ Sciurus rufoniger Pucheran.

Mesosciurus, ibid., p. 212. Type, Sciurus cestuans var. hoffmanni Peters.

Histriosciurus, ibid., p. 213 (subgenus of Mesosciurus). Type, Sciurus gerrardi Gray.

Hadrosciurus, ibid., p. 265. Type, Sciurus flammifer Thomas.

Urosciurus, ibid., p. 267. Type, Sciurus tricolor Pœppig.

Simosciurus, ibid., p. 280. Type, Sciurus stramineus Eydoux and Souleyet.

Isolobodon, Ann. New York Acad. Sci., XXXVII, p. 19, Jan. 26, 1916. Type, Isolobodon portoricensis sp. nov.

\section{Species ANd Subspecies.}

1874.

Tamias quadrivittatus var. pallidus, Proc. Boston Soc. Nat. Hist., XVI, Feb. 1874, p. 289. (Eutamias.) ${ }^{1}$

Spermophilus tridecemlineatus var. pallidus, ibid., p. 291. (Ictidomys.)

Spermophilus parryi var. kodiacensis, ibid., p. 291. (Citellus.)

1876.

Canis mississippiensis, Amer. Journ. Sci. and Arts, ser. 3, XI, Jan. 1876, p. 49. (Extinct.)

1 Present current generic and specific names are given in parentheses when different from those originally employed. 
Cervus whitneyi, ibid., p. 49. (Extinct.)

Bassaricyon gabbi, Proc. Acad. Nat. Sci. Philadelphia, 1876, p. 20.

1877.

Lepus sylvaticus var. arizonce, Mon. N. Amer. Roden., p. 332, August, 1877. (Sylvilagus audubonii arizonce.)

Lepus graysoni, ibid., p. 347. (Sylvilagus.)

Lepus brasiliensis var. gabbi, ibid., p. 419. (Sylvilagus.)

Tamias asiaticus var. borealis, ibid., p. 793. (Eutamias quadrivittatus borealis.)

1885.

Pachycyon robustus, Mem. Mus. Comp.Zoöl., X, pp. 4-8, pll. i-iii, 1885. (Extinct.)

1887.

Squalodon tiedemani, Bull. Amer. Mus. Nat. Hist., II, p. 34, April 25, 1887. (Extinct.)

1889.

Sciurus alstoni, Bull. Amer. Mus. Nat. Hist., II, p. 167, Oct. 21, 1889 (name preoccupied; replaced by S. nayaritensis Allen, 1889).

Tamias asiaticus bulleri, ibid., p. 173. (Eutamias bulleri.)

Tamias asiaticus merriami, ibid., p. $176 . \quad$ (Eutamias merriami.)

Sigmodon fulviventer, ibid., p. 180.

1890.

Tamias obscurus, Bull. Am. Mus. Nat. Hist., III, p. 70, June, 1890. (Eutamias.)

Tamias senex, ibid., p. 83. (Eutamias.)

Tamias frater, ibid., p. 88 . (Eutamias.)

Tamias amœnus, ibid., p. 90. (Eutamias.)

Tamias cinereicollis, ibid., p. $94 . \quad$ (Eutamias.)

Tamias umbrinus, ibid., p. $96 . \quad$ (Eutamias.)

Tamias quadrivittatus gracilis, ibid., p. $99 . \quad$ (Eutamias.)

Tamias quadrivittatus luteiventris, ibid., p. 101. (Eutamias.)

Tamias quadrivittatus affinis, ibid., p. $103 . \quad$ (Eutamias.)

Tamias quadrivittatus neglectus, ibid., p. 106. (Eutamias.)

Tamias minimus consobrinus, ibid., p. 112. (Eutamias.)

Tamias minimus pictus, ibid., p. 115. (Eutamias.)

Lepus cinerasiens, Bull. Am. Mus. Nat. Hist., III, p. 159, Oct., 1890. (Sylvilagus.)

Lepus sylvaticus floridanus, ibid., p. 160. (Sylvilagus.)

Sciurus hudsonius vancouverensis, Bull. Am. Mus. Nat. Hist., III, p. 165, Nov. 14, 1890.

Sciurus hudsonius californicus, ibid., p. 165 (name preoccupied; replaced by S. albolimbatus Allen, 1898).

Artibeus coryi, Bull. Am. Mus. Nat. Hist., III, p. 173, Nov. 14, 1890.

Vespertilio velifer, Bull. Am. Mus. Nat. Hist., III, p. 177, Dec. 10, 1890. (Myotis.)

Sciurus cervicalis, ibid., p. 183.

Lepus sylvaticus aztecus, ibid., p. 188. (Sylvilagus floridanus aztecus.)

Lepus insolitus, ibid., p. 189. (Sylvilagus cunicularius insolitus.)

Lepus truei, ibid., p. 192. (Sylvilagus.) 
1891.

Histiotus maculatus, Bull. Am. Mus. Nat. Hist., III, p. 195, Feb. 20, 1891. (Euderma maculatum.)

Blarina costaricensis, Bull. Am. Mus. Nat. Hist., III, p. 205, April 17, 1891. (?= Blarina brevicauda.)

Hesperomys (Vesperimus) cherriei, ibid., p. 211. (Reithrodontomys.)

Hesperomys (Vesperimus) nudipes, ibid., p. 213. (Peromyscus.)

Hesperomys (Oryzomys) alfaroi, ibid., p. 214. (Oryzomys.)

Scalops argentatus texanus, ibid., p. 221. (Scalopus.)

Dipodops sennetti, ibid., p. $226 . \quad$ (Perodipus.)

Dipodops ordii palmeri, Bull. Am. Mus. Nat. Hist., III, p. 276, June 30, 1891. (Perodipus.)

Dipodops richardsoni, ibid., p. 277. (Perodipus.)

Perognathus (Chotodipus) femoralis, ibid., p. 281.

Neotoma micropus canescens, ibid., p. 285.

Oryzomys aquaticus, ibid., p. 289.

Vesperimus difficilis, ibid., p. 298. (Peromyscus.)

Vesperimus nasutus, ibid., p. 299. (Peromyscus.)

Vesperimus mearnsi, ibid., p. 300. (Peromyscus.)

Capromys ingrahami, Bull. Am. Mus. Nat. Hist., III, p. 329, Aug. 31, 1891.

Oryzomys talamance, Proc. U. S. Nat. Mus., XIV, 1891, p. 193.

Hesperomys (Vesperimus) affinis, ibid., p. 195. (Peromyscus.)

1892.

Perognathus merriami, Bull. Am. Mus. Nat. Hist., IV, p. 45, pl. iii, March 25, 1892.

Atalapha brachyotis, ibid., p. 47. (Lasiurus.)

Oryzomys bauri, ibid., p. 48.

1893.

Sciurus apache, Bull. Am. Mus. Nat. Hist., V, p. 29, March 16, 1893.

Thomomys monticolus, Bull. Am. Mus. Nat. Hist., V, p. 48, April 28, 1893.

Thomomys aureus, ibid., p. 49.

Thomomys fossor, ibid., p. 51.

Thomomys toltecus, ibid., p. 52.

Zapus princeps, Bull. Am. Mus. Nat. Hist., V, p. 71, April 28, 1893.

Arvicola (Mynomes) aztecus, ibid., p. 73. (Microtus.)

Reithrodontomys aztecus, ibid., p. 79.

Sitomys auripectus, ibid., p. 75. (Peromyscus.)

Sitomys rowleyi, ibid., p. 76. (Peromyscus.)

Sitomys americanus thurberi, Bull. Am. Mus. Nat. Hist., V, p. 185, August 18, 1893. (Peromyscus.)

Sitomys martirensis, ibid., p. 187. (Peromyscus.)

Sitomys gilberti, ibid., p. 188. (Peromyscus.)

Tamias leucurus peninsulce, ibid., p. 197. (Ammospermophilus.)

Scapanus anthonyi, ibid., p. 200.

“Chæronycteris intermedia, Bull. Am. Mus. Nat. Hist., V, p. 207, Sept. 21, 1893 (with F. M. Chapman). 
Nectomys palmipes, ibid., p. 209.

Tylomys couesi, ibid., p. 211. (Rhipidomys.)

Oryzomys speciosus, ibid., p. 212.

Oryzomys trinitatis, ibid., p. 213.

Oryzomys velutinus, ibid., p. 214.

Oryzomys brevicauda, ibid., p. 215. (Zygodontomys.)

Loncheres castaneus, ibid., p. 222.

Echimys trinitatis, ibid., p. 223. (Proechimys.)

Oryzomys costaricensis, Bull. Am. Mus. Nat. Hist., V, p. 239, Sept. 22, 1893.

Didelphys (Micoureus) canescens, ibid., p. 235. (Marmosa.)

Sitomys robustus, Bull. Am. Mus. Nat. Hist., V, p. 335, Dec. 16, 1893. (Peromyscus.)

Geomys cherriei, ibid., p. 337 . (Macrogeomys.)

1894.

Evotomys fuscodorsalis, Bull. Am. Mus. Nat. Hist., VI, p. 103, April 14, 1894. (Evotomys gapperi.)

Lepus sylvaticus mearnsi, Bull. Am. Mus. Nat. Hist., VI, p. 171, May 31, 1894. (Sylvilagus.)

Oryzomys palustris texensis, ibid., p. 177.

Perognathus pricei, Bull. Am. Mus. Nat. Hist., VI, p. 318, Nov. 7, 1894.

Perognathus conditi, ibid., p. 318.

Reithrodontomys mexicanus fulvescens, ibid., p. 319.

Arvicola leucophceus, ibid., p. 321. (Microtus.)

Sitomys americanus arizonœ, ibid., p. 321. (Peromyscus.)

Neotoma campestris, ibid., p. 322.

Neotoma rupicola, ibid., p. 323.

Neotoma grangeri, ibid., p. 324.

Sciurus hudsonicus dakotensis, ibid., p. 325.

Phenacomys truei, ibid., p. 331.

Arvicola insperatus, Bull. Am. Mus. Nat. Hist., VI, p. 347, Dec. 7, 1894. (Microtus.)

Lepus texianus eremicus, ibid., p. 347.

Lepus sylvaticus pinetis, ibid., p. 348. (Sylvilagus nuttalli pinetis.)

Sciurus arizonensis huachuca, ibid., p. 349.

Sciurus hudsonicus grahamensis, ibid., p. 350.

\section{5.}

Reithrodontomys merriami, Bull. Am. Mus. Nat. Hist., VII, p. 119, May 21, 1895.

Reithrodontomys dychei, ibid., p. 120.

Reithrodontomys dychei nebrascensis, ibid., p. 122.

Reithrodontomys megalotis deserti, ibid., p. 127.

Reithrodontomys arizonensis, ibid., p. 134.

Reithrodontomys mexicanus intermedius, ibid., p. 136.

Reithrodontomys mexicanus aurantius, ibid., p. 137.

Reithrodontomys costaricensis, ibid., p. 139.

Lynx texensis, Bull. Am. Mus. Nat. Hist., VII, p. 188, June 20, 1895.

Thomomys cervinus, Bull. Am. Mus. Nat. Hist., VII, p. 203, June 29, 1895.

Lepus sylvaticus grangeri, Bull. Am. Mus. Nat. Hist., VII, p. 264, August 21, 1895.

(Sylvilagus nuttalli grangeri.) 
Lepus aquaticus attwateri, Bull. Am. Mus. Nat. Hist., VII, p. 327, Nov. 8, 1896. (Sylvilagus.)

Reithrodontomys australis, ibid., p. 328.

Oryzomys cherriei, ibid., p. 329. (Zygodontomys.)

Peromyscus attwateri, ibid., p. 330.

Neotoma cinnamomea, ibid., p. 331.

Sciurus (Microsciurus) alfari, ibid., p. 333. (Microsciurus.)

Tamias pricei, ibid., p. $333 . \quad$ (Eutamias.)

Tamias wortmani, ibid., p. 335. ' (Callospermophilus.)

Spermophilus tridecemlineatus olivaceus, ibid., p. 337. (Ictidomys.)

Spermophilus tridecemlineatus parvus, ibid., p. 337. (Ictidomys.)

Blarina (Soriciscus) nigrescens, ibid., p. 339. (Cryptotis.)

Blarina (Soriciscus) orophila, ibid., p. 340. (Cryptotis.)

1896.

Rangifer terrænovœ, Bull. Am. Mus. Nat. Hist., VIII, p. 233, Nov. 21, 1896.

Reithrodontomys laseyi, ibid., p. 235.

Perognathus mearnsi, ibid., p. 237.

Peromyscus michiganensis pallescens, ibid., p. 238.

Vespertilio incautus, ibid., p. 239. (Myotis.)

Vespertilio chrysonotus, ibid., p. $340 . \quad$ (Myotis.)

1897.

Peromyscus yucatanicus, Bull. Am. Mus. Nat. Hist., IX, p. 8, Feb. 23, 1897 (with F. M. Chapman).

Reithrodontomys mexicanus gracilis, ibid., p. 9.

Heteromys gaumeri, ibid., p. 9.

Artibeus palmarum, Bull. Am. Mus. Nat. Hist., IX, p. 16, Feb. 26, 1897 (with F. M. Chapman).

Oryzomys delicatus, ibid., p. 19.

Akodon urichi, ibid., p. 19.

Akodon frustrator, ibid., p. 20.

Thylamys carri, ibid., p. 27.

Artibeus intermedius, Bull. Am. Mus. Nat. Hist., IX, p. 33, March 11, 1897.

Oryzomys chrysomelas, ibid., p. 37. (Melanomys.)

Sigmodontomys alfari, ibid., p. 39. (Nectomys.)

Sigmodon borucce, ibid., p. 40.

Peromyscus spicilegus, Bull. Am. Mus. Nat. Hist., IX, p. 50, March 15, 1897.

Peromyscus banderanus, ibid., p. 51.

Oryzomys mexicanus, ibid., p. 52.

Oryzomys bulleri, ibid., p. 53.

Sigmodon mascotensis, ibid., p. 54.

Sigmodon colima, ibid., p. 55.

Heteromys hispidus, ibid., p. 56. (Liomys.)

Ovis stonei, Bull. Am. Mus. Nat. Hist., IX, p. 111, April 7, 1897.

Sciurus (Microsciurus) peruanus, Bull. Am. Mus. Nat. Hist., IX, p. 115, April 26, 1897. (Microsciurus.) 
Oryzomys baroni, ibid., p. 118.

Sigmodon peruanus, ibid., p. 118.

Sigmodon bogotensis, Bull. Am. Mus. Nat. Hist., IX, p. 121, May 24, 1897.

Mus musculus jalapce, Bull. Am. Mus. Nat. Hist., IX, p. 198, June 16, 1897 (with. F. M. Chapman).

Reithrodontomys rufescens, ibid., p. 199.

Reithrodontomys saturatus, ibid., p. 201.

Peromyscus furvus, ibid., p. 201.

Peromyscus melanotis, ibid., p. 203.

Peromyscus musculus brunneus, ibid., p. 203.

Oryzomys jalapce, ibid., p. 206.

Adelonycteris gaumeri, Bull. Am. Mus. Nat. Hist., IX, p.231, Sept. 28, 1897. (Eptesicus.)

1898.

Marmosa sinaloce, Bull. Am. Mus. Nat. Hist., X, p. 143, April 12, 1898.

Lepus peninsularis, ibid., p. 144. (Sylvilagus.)

Lepus cerrosensis, ibid., p. 145 . (Sylvilagus.)

Lepus arizonce confinis, ibid., p. 146. (Sylvilagus.)

Thomomys fulvus anito, ibid., p. 146.

Thomomys fulvus martirensis, ibid., p. 147.

Thomomys atrovarius, ibid., p. 148.

Perognathus pernix, ibid., p. 149.

Neotoma sinaloce, ibid., p. 149.

Neotoma arenacea, ibid., p. 150.

Neotoma anthonyi, ibid., p. 151.

Peromyscus eremicus propinquus, ibid., p. 154.

Peromyscus cedrocensis, ibid., p. 154.

Peromyscus cineritius, ibid., p. 155.

Peromyscus geronimensis, ibid., p. 156.

Peromyscus exiguus, ibid., p. 157.

Peromyscus dubius, ibid., p. 157.

Sciurus hudsэnicus baileyi, Bull. Am. Mus. Nat. Hist., X, p. 261, August 31, 1898.

Sciurus hudsoni:us ventorum, ibid., p. 263.

Sciurus hudsonicus streatori, ibid., p. 267.

Sciurus douglasii cascadensis, ibid., p. 277.

Sciurus fremonti neomexicanus, ibid., p. 291.

Sciurus wagneri, Bull. Am. Mus. Nat. Hist., X, p. 453, Nov. 1898 (nom. nov., given in. error to replace $S$. varius Wagner, preoccupied).

Sciurus douglasii albolimbatus, ibid., p. 453 (to replace Sciurus hudsmius californicus Allen, 1890, preoccupied).

1899.

Zapus saltator, Bull. Am. Mus. Nat. Hist., XII, p. 3, March 4, 1899.

Phenacomys constablei, ibid., p. 4.

Microtus stonei, ibid., p. 5. (Microtus drummondii.)

Microtus vellerosus, ibid., p. 7. (Microtus mordax.)

Microtus cautus, ibid., p. 7. (Microtus mordax.) 
Lepus americanus phoeonotus, ibid., p. 11.

Lepus bishopi, ibid., p. 11.

Lepus floridanus chapmani, ibid., p. 13. (Sylvilagus.)

Thomomys fulvus alticolus, ibid., p. 13.

Reithrodontomys tenuis, ibid., p. 15.

Peromyscus texanus subarcticus, ibid., p. 15. (Peromyscus maniculatus artemisia.)

Sciurus chapmani, ibid., p. 16. (Mesosciurus.)

Lepus (Sylvilagus) superciliaris, Bull. Am. Mus. Nat. Hist., XII, p. 196, Dec. 20, 1899.

Isothrix rufodorsalis, ibid., p. 197.

Echimys mince, ibid., p. 199. (Proechimys.)

Echimys urichi, ibid., p. 199. (Proechimys.)

Echimys canicollis, ibid., p. 200. (Proechimys.)

Heteromys jesupi, ibid., p. 201.

Akodon venezuelensis, ibid., p. 203.

Akodon colombianus, ibid., p. 203. (Melanomys.)

Oryzomys maculiventer, ibid., p. 204.

Oryzomys trichurus, ibid., p. 206. (Ecomys.)

Oryzomys sanctcemartoe, ibid., p. 207.

Oryzomys mollipilosus, ibid., p. 208.

Oryzomys magdalence, ibid., p. 209.

Oryzomys villosus, ibid., p. 210.

Oryzomys palmarius, ibid., p. 210.

Oryzomys tenuicauda, ibid., p. 211.

Oryzomys modestus, ibid., p. 212.

Oryzomys fulviventer, ibid., p. 212.

Sciurus saltuensis bondo, ibid., p. 213.

Sciurus (Guerlinguetus) quebradensis, p. 217. (= Mesosciurus chapmani.)

1900.

Chiroderma jesupi, Bull. Am. Mus. Nat. Hist., XIII, p. 88, May 12, 1900.

Mycronycteris hypoleuca, ibid., p. 90.

Promops affinis, ibid., p. 91.

Promops milleri, ibid., p. 92.

Caluromys alstoni, Bull. Am. Mus. Nat. Hist., XIII, p. 189, Oct. 12, 1900. (Philander.)

Didelphis pernigra, Bull. Am. Mus. Nat. Hist., XIII, p. 191, Oct. 23, 1900.

Didelphis karkinophaga cauca, ibid., p. 192.

Didelphis karkinophaga colombica, ibid., 193.

Metachirus fuscogriseus, ibid., p. 194.

Metachirus tschudii, ibid., p. 195.

Metachirus nudicaudatus colombianus, ibid., p. 196.

Marmosa chapmani, ibid., p. 197.

Marmosa klagesi, ibid., p. 198.

Thylamys keaysi, ibid., p. 198.

Dactylomys peruanus, Bull. Am. Mus. Nat. Hist., XIII, p. 220, Nov. 16, 1900.

Oxymycterus juliacæe, ibid., p. 223. 
Oxymycterus apicalis, ibid., p. 224. (Lenoxus.)

Oryzomys keaysi, ibid., p. 225.

Oryzomys obtusirostris, ibid., p. 226.

1901.

Zygodontomys thomasi, Bull. Am. Mus. Nat. Hist., XIV, p. 39, Jan. 31, 1901.

Sigmodon simonsi, ibid., p. 40.

Rhipidomys ochrogaster, ibid., p. 43.

Phyllotis osilce, ibid., p. 44.

Akodon lutescens, ibid., p. 46.

Rangifer stonei, Bull. Am. Mus. Nat. Hist., XIV, p. 143, May 28, 1901.

Didelphis marsupialis texensis, Bull. Am. Mus. Nat. Hist., XIV, p. 172, June 15, 1901.

Didelphis marsupialis tabascensis, ibid., p. 173.

Didelphis richmondi, ibid., p. 175.

Didelphis yucatanensis, ibid., p. 178.

Metachirus fuscogriseus pallidus, Bull. Am. Mus. Nat. Hist., XIV, p. 215, July 3, 1901.

Metachirus griscescens, ibid., p. 217.

Orizomys bolivaris, Bull. Am. Mus. Nat. Hist., XIV, p. 405, Nov. 30, 1901.

Oryzomys castaneus, ibid., p. 406.

Oryzomys perenensis, ibid., p. 406.

Oryzomys rivularis, ibid., p. 407.

Phyllotis chacoensis, ibid., p. 408.

Phyllotis cachinus, ibid., p. 409.

Eligmodontia morgani, ibid., p. 409.

Akodon tucumanensis, ibid., p. 410.

Metachirus nudicaudatus bolivianus, ibid., p. 411.

1902.

Dama lichtensteini, Bull. Am. Mus. Nat. Hist., XVI, p. 20, Feb. 1, 1902 (nom. nov., to replace Cervus mexicanus Lichtenstein held to be preoccupied by Cervus mexicanus Gmelin, unidentifiable.) (Odocoileus.)

Rangifer granti, Bull. Am. Mus. Nat. Hist., XVI, p. 119, April 7, 1902.

Ursus merriami, Bull. Am. Mus. Nat. Hist., XVI, p. 141, April 12, 1902.

Rangifer osborni, Bull. Am. Mus. Nat. Hist., XVI, p. 149, April 16, 1902.

Ovis dalli kenaiensis, Bull. Am. Mus. Nat. Hist., XVI, p. 145, April 23, 1902.

Didelphis marsupialis insularis, Bull. Am. Mus. Nat. Hist., XVI, p. 259, August 18, 1902.

Didelphis marsupialis caucce, ibid., p. 261.

Didelphis marsupialis etensis, ibid., p. 262.

Didelphis paraguayensis andina, ibid., p. 272.

Didelphis paraguayensis meridensis, ibid., p. 274.

Rangifer pearyi, Bull. Am. Mus. Nat. Hist., XVI, p. 409, Oct. 31, 1902.

Phoca hispida gichigensis, Bull. Am. Mus. Nat. Hist., XVI, p. 478, Dec. 12, 1902.

Phoca ochotensis macrodens, ibid., p. 483.

Phoca stejnegeri, ibid., p. 485.

Phoca richardii pribilofensis, ibid., p. 495.

Phoca richardii geronimensis, ibid., p. 495. 
1903.

Sigmodon puna, Bull. Am. Mus. Nat. Hist., XIX, p. 99, March 20, 1903.

Citellus buxtoni, Bull. Am. Mus. Nat. Hist., XIX, p. 139, May 9, 1903.

Citellus stejnegeri, ibid., p. 142.

Evotomys (Craseomys) latastei, ibid., p. 145.

Evotomys jochelsoni, ibid., p. 148.

Lemmus obensis chrysogaster, ibid., p. 153.

Ochotona kolymensis, ibid., p. 154.

Lepus gichiganus, ibid., p. 155.

Vulpes anadyrensis, ibid., p. 167.

Putorius (Arctogale) pygmous, ibid., p. 176. (Mustela.)

Erinaceus orientalis, ibid., p. 179.

Sorex buxtoni, ibid., p. 181.

Ctenomys robustus, Bull. Am. Mus. Nat. Hist., XIX, p. 185, May 9, 1903. (C.osgoodi.),

Ctenomys sericeus, ibid., p. 187.

Ctenomys colborni, ibid., p. 188.

Oxymycterus microtis, ibid., p. 189.

Reithrodon cuniculoides obscurus, ibid., p. 190.

Reithrodon hatcheri, ibid., p. 191.

Euneomys petersoni, ibid., p. 192.

Citellus stonei, Bull. Am. Mus. Nat. Hist., XIX, p. 537, Oct. 10, 1903.

Synaptomys (Mictomys) andersoni, ibid., p. 554.

Synaptomys (Mictomys) chapmani, ibid., p. 555.

Erethizon epizanthus nigrescens, ibid., p. 558.

Putorius microtis, ibid., p. 563. (Mustela.)

Odocoileus battyi, Bull. Am. Mus. Nat. Hist., XIX, p. 591, Nov. 13, 1903.

Eutamias durangce, ibid., p. 594.

Citellus (Otospermophilus) grammurus rupestris, ibid., p. 595.

Peromyscus paulus, ibid., p. 598.

Peromyscus texanus flaccidus, ibid., p. 599. (Peromyscus leucopus tornillo.)

Sigmodon baileyi, ibid., p. 601.

Reithrodontomys megalotis sestinensis, ibid., p. 602.

Neotoma intermedia durangce, ibid., p. 602.

Perodipus obscurus, ibid., p. 603.

Lepus (Macrotolagus) texianus micropus, ibid., p.605. (Lepus californicus texianus.)

Lepus (Macrotolagus) gaillardi battyi, ibid., p. 607.

Lepus (Sylvilagus) durango, ibid., p. 609. (Sylvilagus floridanus holzneri.)

Canis impavidus, ibid., p. 609.

Myotis californicus durango, ibid., p. 612.

Odocoileus sinaloce, ibid., p. 613.

Lynx ruffus escuinapce, ibid., p. 614.

1904.

Oreamnos montanus columbianus, Bull. Am. Mus. Nat. Hist., XX, p. 20, Feb. 10. 1904. (O. americanus columbice.)

Oreamnos montanus missoulce, ibid., p. 20. (O. americanus missoulc.)

Lepus (Sylvilagus) russatus, Bull. Am. Mus. Nat. Hist., XX, p. 31, Feb. $29,1904$. 
Lepus (Sylvilagus) parvulus, ibid., p. 34.

Tayra barbara irara, ibid., p. 36.

Akodon irazu, ibid., p. $46 . \quad$ (Scoteomys.)

Felis carrikeri, ibid., p. 47.

Nasua narica bullata, ibid., p. 48.

Nasua narica panamensis, ibid., p. 51.

Nasua narica yucatanica, ibid., p. 52.

Nasua narica pallida, ibid., p. 53.

Sigmodon borucce chiriquensis, ibid., p. 68.

Felis mearnsi, ibid., p. 71 (nom. nov., to replace $F$. costaricensis, preoccupied).

Felis panamensis, ibid., p. 71.

Potos flavus chiriquensis, ibid., p. 74.

Potos flavus caucensis, ibid., p. 75.

Potos flavus chapadensis, ibid., p. 76.

Myotis chiriquensis, ibid., p. 77.

Sciurus aberti phœurus, Bull. Am. Mus. Nat. Hist., XX, p. 205, May 28, 1904.

Sciurus aberti barberi, ibid., p. 207.

Eutamias canescens, ibid., p. 208.

Molossus coibensis, Bull. Am. Mus. Nat. Hist., XX, p. 227, June 29, 1904.

Molossus bondo, ibid., p. 228.

Promops barbatus, ibid., p. 228.

Dermonotus suarpurensis, ibid., p. 229.

Lonchophylla thomasi, ibid., p. 230.

Artibeus rusbyi, ibid., p. 230.

Artibeus insularis, ibid., p. 231.

Artibeus yucatanicus, ibid., p. 232.

Phyllostoma hastatus panamensis, ibid., p. 233.

Phyllostoma hastatus caurce, ibid., p. 234.

Ovis storcki, Bull. Am. Mus. Nat. Hist., XX, p. 293, Sept. 8, 1904.

Peramys brevicaudatus dorsalis, Bull. Am. Mus. Nat. Hist., XX, p. 327, Oct. 8, 1904.

Oryzomys tenuipes, ibid., p. 328.

Akodon meridensis, ibid., p. 329.

Holochilus venezuelensis, ibid., p. 330.

Felis maripensis, ibid., p. 331.

Felis sanctcomarto, ibid., p. 332.

Procyon proteus, ibid., p. 333.

Nasua phoocephala, ibid., p. 334.

Erethizon godfreyi, Bull. Am. Mus. Nat. Hist., XX, p. 383, Oct. 15, $1904 . \quad$ (Extinct.)

Tamandua tetradactyla chapadensis, Bull. Am. Mus. Nat. Hist., XX, p. 392, Oct. 29, 1904.

Tamandua tetradactyla instabilis, ibid., p. 392.

Tamandua tetradactyla tenuirostris (= mexicana Saussure, 1860), ibid., p. 394.

Tamandua tetradactyla chiriquensis, ibid., p. 395.

Coendou sanctcemarto, Bull. Am. Mus. Nat. Hist., XX, p. 441, Nov. 28, 1904.

Lutra colombiana, ibid., p. 452.

Alouatta seniculus rubicunda, ibid., p. 458.

Alouatta seniculus caucensis, ibid., p. 462. 
1905.

Eutamias lectus, Science Bull. Brooklyn Inst. Arts and Sciences, I, No. 6, p. 117, March 31, 1905.

Eutamias adsitus, ibid., p. 118.

Cynomys parvidens, ibid., p. 119.

Marmota engelhardti, ibid., p. 120.

Ochotona cinnamomea, ibid., p. 121.

Ctenomys osgoodi, Mamm. Patagonia, in Princeton Univ. Exped. to Patagonia, III, pt. i, p. 191 (nom. nov., to replace $C$. robustus Allen, preoccupied).

Canis sclater:, ibid., p. 153 (nom. nov., to replace C. microtis Sclater, preoccupied).

1906.

Heteromys pictus escuinapæ, Bull. Am. Mus. Nat. Hist., XXII, p. 211, July 25, 1906 (Liomys.)

Molossus sinaloc, ibid., p. 236.

Sciurus poliopus tepicanus, ibid., p. 243.

Sigmodon vulcani, ibid., p. 247.

Heteromys jaliscensis, ibid., p. 251.

Manis pusilla, Bull. Am. Mus. Nat. Hist., XXII, p. 465, Dec. 17, 1906.

Atherurus hainanus, ibid., p. 470.

Ratufa gigantea hainana, ibid., p. 472.

Funambulus riudonensis, ibid., p. 472.

Sciurus erythræus insularis, ibid., p. 473.

Tamiops macclellandi hainanus, ibid., p. 476.

Tamiops macclellandi riudoni, ibid., 477.

Tupaia modesta, ibid., p. 481.

Rhinolophus hainanus, ibid., p. 482.

Hipposideros poutensis, ibid., p. 483.

Scotophilus kuhlii insularis, ibid., p. 485.

Scotophilus castaneus consobrinus, ibid., p. 485.

Pipistrellus portensis, ibid., p. 487.

1907 (None).

1908.

Ardops haitiensis, Bull. Am. Mus. Nat. Hist., XXIV, p. 581, Sept. 11, 1908.

Molossus verrilli, ibid., p. 581.

Lepus gabbi tumacus, Bull. Am. Mus. Nat. Hist., XXIV, p. 649, Oct. 13, 1908. (Sylvilagus.)

Hoplomys truei, ibid., p. 650.

Heteromys vulcani, ibid., p. 652 . (Liomys.)

Heteromys fuscatus, ibid., p. 652.

Neotoma chrysomelas, ibid., p. 653.

Oryzomys alfaroi incertus, ibid., p. 655. (O. alfaroi.)

Oryzomys ochraceus, ibid., p. 655.

Oryzomys carrikeri, ibid., p. 656. 
Sigmodon hispidus griseus, ibid., p. 657.

Ototylomys fumeus, ibid., p. 658.

Peromyscus nicaraguce, ibid., p. 658. (P. mexicanus saxatilis.)

Sciurus deppei matagalpce, ibid., p. 660.

Lutra latidens, ibid., p. 660.

Tayra barbara inserta, ibid., p. 662.

Bassaricyon richardsoni, ibid., p. 662.

Blarina olivaceus, ibid., p. 669. (Cryptotis.)

Artibeus jamaicensis richardsoni, ibid., p. 669.

Alouatta palliata matagalpce, ibid., p. 670. (= A. palliata palliata.)

1909.

Tragelaphus tjaderi, Bull. Am. Mus. Nat. Hist., XXVI, p. 148, March 19, 1909.

Madoqua langi, ibid., p. 153.

Arvicanthis nairobce, ibid., p. 168.

Mus kijabius, ibid., p. 169.

Crocidura kijabse, ibid., p. 173.

Paradoxurus (Paguma) larvatus hainanus, Bull. Am. Mus. Nat. Hist., XXVI, p. 240, April 17, 1909.

Mungos rubrifrons, ibid., p. 240.

Myotalpa rufescens, Bull. Am. Mus. Nat. Hist., XXVI, p. 428, Oct. 21, 1909.

Sciurotamias owstoni, ibid., p. 428.

Eutamias albogularis, ibid., p. 429.

1910.

Ursus americanus kenaiensis, Bull. Am. Mus. Nat. Hist., XXVIII, p. 6, Jan. 5, 1910. (U. americanus pernigra.)

Mus luteiventris, ibid., p. 14.

Arctictis whitei, ibid., p. 17.

Mungos palawanus, ibid., p. 17.

Macrogeomys matagalpee, Bull. Am. Mus. Nat. Hist., XXVIII, p. 97, April 30, 1910.

Oryzomys richardsoni, ibid., p. 99.

Oryzomys nicaragua, ibid., p. 100.

Conepatus nicaraguce, ibid., p. 106.

Ursus americanus perniger, ibid., p. 115 (nom. nov., to replace $U$.a. kenaiensis Allen, preoccupied).

Chrotopterus carrikeri, Bull. Am. Mus. Nat. Hist., XXVIII, p. 147, May 27, 1910.

\section{1.}

Cavia porcella venezuelce, Bull. Am. Mus. Nat. Hist., XXX, p. 250, Dec. 2, 1911.

Loncheres carrikeri, ibid., p. 251.

Urocyon cinereoargentea venezuela, ibid., p. 259.

Chilonycteris rubiginosa fusca, ibid., p. 262.

Mus andrewsi, Bull. Am. Mus. Nat. Hist., XXX, p. 336, Dec. 21, 1911.

Mus buruensis, ibid., p. 336.

Sciurus beebei, ibid., p. 338.

Tamiops sauterei, ibid., p. 339. 
1912.

Sylvilagus (Tapeti) fulvescens, Bull. Am. Mus. Nat. Hist., XXXI, p. 75, April 19, 1912.

Heteromys lomitensis, ibid., p. 77. (=H. australis Thomas.)

Reithrodontomys milleri, ibid., p. 77.

Rhipidomys mollissimus, ibid., p. 78.

Rhipidomys similis, ibid., p. 79.

Rhipidomys cocalensis, ibid., p. 79.

Thomasomys cinereiventer, ibid., p. 80.

Thomasomys popayanus, ibid., p. 81.

Neacomys pusillus, ibid., p. 81.

Oryzomys palmira, ibid., p. 83.

Oryzomys pectoralis, ibid., p. 83.

Oryzomys (Oligoryzomys) munchiquensis, ibid., p. 85.

Oryzomys (Oligoryzomys) fulvirostris, ibid., p. 86.

Oryzomys (Melanomys) obscurior affinis, ibid., p. 88. (Melanomys affinis.)

Aipeomys fuscatus, ibid., p. 89.

Microxus affinis, ibid., p. 89.

Sciurus milleri, ibid., p. 91. (Mesosciurus gerrardi milleri.)

Blarina (Cryptotis) squamipes, ibid., p. 93.

Ochotona figginsi, Bull. Am. Mus. Nat. Hist., XXXI, p. 103, May 28, 1912.

1913.

Ochotona (Pika) coreanus, Bull. Am. Mus. Nat. Hist., XXXII, p. 429, Sept. 2, 1913. Meles melanogenys, ibid., p. 433.

Cholcepus florencia, Bull. Amer. Mus. Nat. Hist., XXXII, p. 469, Sept. 25, 1913.

Cholopus agustinus, ibid., p. 470.

Cholop us andinus, ibid., p. 472.

Cholæpus capitalis, ibid., p. 472.

Tayassu niger, ibid., p. 476.

Sylvilagus (Tapeti) salentus, ibid., p. 476.

Myoprocta milleri, ibid., p. 477.

Coendu quichua richardsoni, ibid., p. 478.

Proechimys o'connelli, ibid., p. 479.

Sigmodon chonensis, ibid., p. 479.

Akodon tolima, ibid., p. 480.

Potos flavus tolimensis, ibid., p. 481.

Nasua olivacea laguneto, ibid., p. 483.

Tayra barbara senilis, ibid., p. 484.

Melanomys caliginosus oroensis, Bull. Am. Mus. Nat. Hist., XXXI, p. 538, Nov. 17, 1913.

Melanomys affinis monticola, ibid., p. 540.

Melanomys phropus vallicola, ibid., p. 544.

Melanomys phoeopus tolimensis, ibid., p. 545.

Melanomys lomitensis, ibid., p. 545.

Melanomys buenavistoe, ibid., p. 547. 
Oryzomys helvolus, Bull. Am. Mus. Nat. Hist., XXXII, p. 597, Dec. 3, 1913.

Oryzomys o'connelli, ibid., p. 597.

Oryzomys vicencianus, ibid., p. 598.

Oryzomys incertus, ibid., p. 598. (O. mureliæe.)

Zygodontomys griseus, ibid., p. 599.

Zygodontomys fraterculus, ibid., p. 599.

Akodon chapmani, ibid., p. 600.

Rhipidomys quindianus, ibid., p. 600.

Rhipidomys caucensis, ibid., p. 601.

Rhipidomys venezueloe yuruanus, ibid., p. 601.

Rhipidomys milleri, ibid., p. 602.

Ecomys minca, ibid., p. 603.

Ecomys caicaro, ibid., p. 603.

1914.

Microsciurus rubrirostris, Bull. Am. Mus. Nat. Hist., XXXIII, p. 163, Feb. 26, 1914. Microsciurus florencia, ibid., p. 164.

Sylvilagus daulensis, Bull. Am. Mus. Nat. Hist., XXXIII, p. 199, Feb. 28, 1914.

Thomasomys aureus altorum, ibid., p. 200.

Amorphochilus schnablii osgoodi, Bull. Am. Mus. Nat. Hist., XXXIII, p. 381, July $9,1914$.

Eptesicus andinus, ibid., p. 382.

Dasypterus ega punensis, ibid., p. 382.

Myotis ruber keaysi, ibid., p. 383.

Myotis punensis, ibid., p. 383.

Myotis bonda, ibid., p. 384.

Myotis maripensis, ibid., p. 385.

Myotis esmeraldo, ibid., p. 385.

Myotis caucensis, ibid., p. 386.

Nyctinomus aquatorialis, ibid., p. 386.

Mormopterus peruanus, ibid., p. 387.

Thrinacodus apolinari, ibid., p. 387.

Notosciurus rhoadsi, Bull. Am. Mus. Nat. Hist., XXXIII, p. 585, Oct. 8, 1914.

Guerlinguetus pucheranii salentensis, ibid., p.587. (Leptosciurus.)

Guerlinguetus hoffmanni quindianus, ibid., p. 587. (Mesosciurus.)

Guerlinguetus hoffmanni manavi, ibid., p. 589. (Mesosciurus.)

Guerlinguetus griseimembra, ibid., p. 589. (Mesosciurus.)

Guerlinguetus candelensis, ibid., p. 590. (Mesosciurus.)

Sciurus gerrardi salaquensis, ibid., p. 592. (Mesosciurus.)

Sciurus gerrardi cucuto, ibid., p. 592. (Mesosciurus.)

Sciurus saltuensis magdalenoe, ibid., p. 593. (Mesosciurus.)

Sciurus duida, ibid., p. 594. (Urosciurus.)

Sciurus igniventris zamore, ibid., p. 594. (Urosciurus.)

Sciurus langsdorffi urucumus, ibid., p. 595. (Urosciurus.)

Sciurus langsdorffi steinbachi, ibid., p. 596. (Urosciurus.)

Sciurus stramineus zarume, ibid., p. 597. (Simosciurus.)

Callicebus lugens duida, Bull. Am. Mus. Nat. Hist., XXXIII, p. 647, Dec. 14, 1914.

Alouatta seniculus bogotensis, ibid., p. 648. 
Alouatta seniculus caquetensis, ibid., p. 650.

Pithecia milleri, ibid., p. 650.

Cacajao roosevelti, ibid., p. 651.

Ateles longimembris, ibid., p. 651.

Ateles robustus, ibid., p. 652.

Cebus apella brunneus, ibid., p. 653.

Cebus aquatorialis, ibid., p. 654.

1915.

Guerlinguetus cestuans venustus, Bull. Am. Mus. Nat. Hist., XXXIV, p. 260, May 17, 1915.

Mesosciurus gerrardi baudensis, ibid., p. 308.

Mesosciurus gerrardi valdivia, ibid., p. 309.

Mazama trinitatis, Bull. Am. Mus. Nat. Hist., XXXIV, p. 532, Nov. 2, 1915.

Mazama americana tumatumari, ibid., p. 536.

Mazama americana juruana, ibid., p. 537.

Mazama gualea, ibid., p. 545.

Mazama fuscata, ibid., p. 545.

Mazama zamora, ibid., p. 546.

Mazama murelia, ibid., p. 547.

Mazama cita sanctomarto, ibid., p. 550.

Dasyprocta fuliginosa candelensis, Bull. Am. Mus. Nat. Hist., XXXIV, p. 625, Dec. 30, 1915.

Dasyprocta variegata zamora, ibid., p. 627.

Dasyprocta variegata chocoensis, ibid., p. 627.

Dasyprocta variegata urucuma, ibid., p. 634.

Proechimys kermiti, ibid., p. 629.

Oryzomys mureliae, ibid., p. 630 (to replace Oryzomys incertus Allen, 1913, preoccupied).

Procyon (Euprocyon) aquatorialis, ibid., 630.

Margay tigrina elence, ibid., p. 631.

Margay caucensis, ibid., p. 631.

Oncoides pardalis tumatumari, ibid., p. 632.

Eptesicus chapmani, ibid., p. 632.

1916.

Isolobodon portoricensis, Ann. New York Acad. Sci., XXVII, pp. 17-22, pll. i-iv, Jan. 25, 1916.

Metachirus nudicaudatus antioquia, Bull. Am. Mus. Nat. Hist., XXXV, p. 83, April 28, 1916.

Tamandua tetradactyla punensis, ibid., p. 83.

Sylvilagus boylei, ibid., p. 84.

Cavia (Cavia) anolaima, ibid., p. 85.

Oryzomys barbacoas, ibid., p. 85.

Glossophaga apolinari, ibid., p. 86.

Saimiri caquetensis, ibid., p. 87.

Mustela tropicalis nicaraguce, Bull. Am. Mus. Nat. Hist., XXXV, p. 100, April 28, 1916.

Proechimys boimensis, Bull. Am. Mus. Nat. Hist., XXXV, p. 523, July 24, 1916. 
Ecomys milleri, ibid., p. 523.

Ecomys florencia, ibid., p. 524.

Ecomys emiliae, ibid., p. 525.

Oryzomys (Oligoryzomys) microtis, ibid., p. 525.

Oryzomys (Oligoryzomys) utiaritensis, ibid., p. 527.

Oryzomys (Oligoryzomys) mattogrossa, ibid., p. 528.

$Z$ ygodontomys tapirapoanus, ibid., p. 528.

Molossus cherriei, ibid., p. 529.

Molossus daulensis, ibid., p. 530.

Tapirus terrestris guiania, Bull. Am. Mus. Nat. Hist., XXXV, p. 566, Aug. 9, 1916.

\section{Summary.}

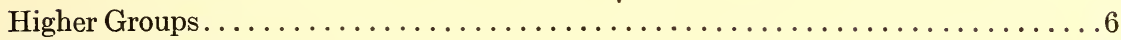

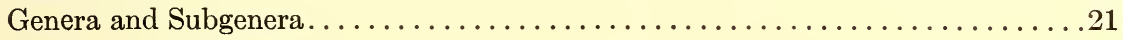

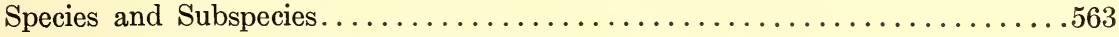

Nomina nova (to replace preoccupied names) $\ldots \ldots \ldots \ldots \ldots \ldots \ldots \ldots \ldots \ldots$ 



\section{INDEX TO MAMMALS.}

Note.- The first reference is to the Bibliography (pp. 50-83), the second to the list of species, subspecies and higher groups (pp. 83-99). The original designation of the form (species of subspecies) is given in full except where a subgeneric name was included, which latter has been omitted in indexing. Under genera subspecies are alphabetized by the subspecific name.

Adelonycteris gaumeri, 66, 89. adsitus, Eutamias, 76, 94. Æpeomys fuscatus, 79, 96. æquatorialis, Cebus, 81, 98.

\section{- Nyctinomus, 81, 97.} Procyon, 82, 98.

affinis, Hesperomys, 60, 86. - Microxus, 79, 96. - Oryzomys obscurior, 79, 96. Promops, 68, 90. Tamias quadrivittatus, 59, 85. agustinus, Cholœpus, 80, 96.

Akodon chapmani, 80, 97. columbianus, 68, 90 . frustrator, 65,88 . irazu, 74, 93 .

lutescens, 70, 91. meridensis, 74, 93. tolimæ, 80, 96. tucumanensis, 70, 91 . urichi, 65, 68 . venezuelensis, 68,90 .

albogularis, Eutamias, 77, 95.

albolimbatus, Sciurus hudsonicus, 66, 89 . alfari, Sciurus, 64, 68 . Sigmodontomys, 65, 88.

alfaroi Hesperomys, 60, 86.

Alouatta seniculus bogotensis, 81, 97. seniculus caquetensis, 81,98 . seniculus caucensis, 75,93 . palliata matagalpæ, 77,95 . seniculus rubicunda, 75, 93.

alstoni, Caluromys, 68, 90. - Sciurus, 58, 85.

alticolus, Thomomys fulvus, 66,89 . altorum, Thomasomys aureus, 81, 97. amœenus, Tamias, 59, 85 .
Amorphochilus schnablii osgoodi, 81, 97. anadyrensis, Vulpes, 73, 92. andersoni, Synaptomys, 73, 92. andina, Didelphis paraguayensis, 72, 91. andinus, Cholœpus, 80, 96. Eptesicus, 81, 97.

andrewsi, Mus, 78, 95. anitæ, Thomomys fulvus, $66,89$. anolaimæ, Cavia, 82, 98. anthonyi, Neotoma, 66, 99. - Scapanus, 61, 86. antioquiæ, Metachirus nudicaudatus, 82 , 98.

apache, Sciurus, 61, 86 . apicalis, Oxymycterus, 69, 91. apolinari, Glossophaga, 82, 98. Thrinacodus, 81, 97. aquaticus, Oryzomys, 60, 86. arenacea, Neotoma, 66, 89. Arctictis whitei, 78, 95 .

Ardops haitiensis, 77, 94. arizonæ, Lepus sylvaticus, 55, 85. Sitomys americanus, $63,87$. arizonensis, Reithrodontomys, 63, 87. Artibeus coryi, 59, 85. insularis, 74, 93. palmarum, 65, 88 . jamaicensis richardsoni, 77, 95 . rusbyi, 74, 93. yucatanicus, 74, 93 . Arvicanthis nairobæ, 77, 95. Arvicola aztecus, 61, 86 . insperatus, $63,87$. leucophæus, 63, 87. Atalapha brachyotis, 60,86 . Ateles longimembris, 81, 98 . robustus, 81,98 . 
Atherurus hainanus, 76, 94

atrovarius, Thomomys, 66, 89.

attwateri, Lepus aquaticus, 64, 88.

Peromyscus, 64, 88.

aurantius, Reithrodontomys mexicanus, $63,87$.

aureus, Thomomys, 61,86 .

auripectus, Sitomys, 61, 86 .

australis, Reithrodontomys, 64, 88.

aztecus, Arvicola, 61, 86.

- Lepus sylvaticus, 59, 85.

Reithrodontomys, 61, 86 .

baileyi, Sciurus hudsonicus, 66,89 .

- Sigmodon, 73, 92.

banderanus, Peromyscus, 65, 88 .

barbacoas, Oryzomys, 82, 98.

barbatus, Promops, 74, 93.

barberi, Sciurus aberti, 74, 93.

baroni, Oryzomys, 66, 89 .

Bassaricyon, 52, 83.

gabbi, 52, 54, 84 .

richardsoni, 77, 95 .

battyi, Lepus gaillardi, 73, 92 .

Odocoileus, 73, 92.

baudensis, Mesosciurus gerrardi, 82, 98 .

baueri, Oryzomys, 60, 86 .

beebei, Sciurus, 78, 95.

bishopi, Lepus, 68, 90.

Blarina costaricensis, 60,86 . nigrescens, 64, 88 .

olivacea, 77, 95 .

orophila, 64,88 .

squamipes, 79, 96 .

bogotensis, Alouatta seniculus, 81, 97. Sigmodon, 66, 89.

boimensis, Proechimys, 83, 98 .

bolivaris, Oryzomys, 70, 91.

bolivianus, Metachirus nudicaudatus, 70, 91.

bondæ, Molossus, 74, 93.

Myotis, 81, 97.

Sciurus saltuensis, 68, 90.

borealis, Tamias asiaticus, 55, 85 .

borucæ, Sigmodon, 65, 88.

boylei, Sylvilagus, 82,98 .

brachyotis, Atalapha, 60, 86 .

brevicauda, Oryzomys, 62, 87.

brunneus, Cebus apella, 81, 98 .

Peromyscus musculus, 66, 89. buenavistæ, Melanomys, 80, 96.

bullata, Nasua narica, 73, 92 .

bulleri, Oryzomys, 65, 88.

Tamias asiaticus, 58, 85.

buruensis, Mus, 78, 95.

buxtoni, Citellus, 73, 92. Sorex, 73, 92.

Cacajao roosevelti, 81, 98. cachinus, Phyllotis, 70, 91. caicaræ, WEcomys, 80, 97.

californicus, Sciurus hudsonius, 59, 85 .

Callicebus lugens duida, 81, 97.

Caluromys, 68, 84. alstoni, 68, 90 .

campestris, Neotoma, 63, 87.

candelensis, Dasyprocta fuliginosa, 82, 98.

Guerlinguetus, 81, 97.

canescens, Didelphys, 62, 87.

Eutamias, 74, 93.

Neotoma micropus, 60, 86.

canicollis, Echimys, 68, 90.

Canis impavidus, 73, 92.

mississippiensis, 52,84 .

sclateri, 75, 94.

capitalis, Cholœpus, 80, 96.

Capromys ingrahami, 60, 86.

caquetensis, Alouatta seniculus, 81, 98. Saimiri, 82, 98.

Carcinocyon, 75, 84.

carri, Thylamys, $65,88$.

carrikeri, Chrotopterus, 78, 95.

Felis, 74, 93.

Loncheres, 78, 95.

Oryzomys, 77, 94.

cascadensis, Sciurus douglasii, 66, 89.

castaneus, Loncheres, 62, 87.

- Oryzomys, 70, 91.

Castoroididæ, 55, 83.

caucæ, Didelphis karkinophaga, 69, 90.

caucensis, Alouatta seniculus, 75, 93.

Margay, 82, 98.

Myotis, 81, 97 .

Potos flavus, 74, 93.

Rhipidomys, 80, 97.

cauræ, Phyllostoma hastatus, 74, 93.

cautus, Microtus, 68, 89.

Cavia anolaimæ, 82, 98.

porcella venezuelæ, 78, 95 . 
Cebus æquatorialis, 81, 98.

apella brunneus, 81, 98 .

cedrosensis, Peromyscus, 66, 89.

cervicalis, Sciurus, 59, 85 .

cervinus, Thomomys, 64, 87.

Cervus whitneyi, 52, 84 .

chacoensis, Phyllotis, 70, 91.

Chæronycteris intermedia, 62, 86. chapadensis, Potos flavus, 74, 93.

Tamandua tetradactyla, 75, 93.

chapmani, Akodon, 80, 97.

Eptesicus, 82, 98.

Lepus floridanus, 68, 90.

Marmosa, 69, 90.

Sciurus, 68, 90.

Synaptomys, 73, 92.

cherriei, Geomys, 62, 87.

- Hesperomys, 60, 86.

- Molossus, 83, 99.

- Oryzomys, 64, 88.

Chilonycteris rubiginosa fusca, 78, 95 .

chiriquensis, Myotis, 74, 93.

- Potos flavus, 74, 93.

Sigmodon borucæ, 74, 93.

- Tamandua tetradactyla, 75, 93.

Chiroderma jesupi, 68, 90.

chocoensis, Dasyprocta variegata, 82, 98.

Cholœpus agustinus, 80, 96.

andinus, 80, 96.

capitalis, 80, 96.

florenciæ, 80, 96.

chonensis, Sigmodon, 80, 96.

Chrotopterus carrikeri, 78, 95.

chrysogaster, Lemmus obensis, 73, 92 .

chrysomelas, Oryzomys, 65, 88.

Neotoma, 77, 94.

chrysonotus, Vespertilio, 65, 88.

cinerascens, Lepus, 59, 85.

cinereicollis, Tamias, 59, 85 .

cinereiventer, Thomasomys, 79, 86 .

cineritius, Peromyscus, 66, 89.

cinnamomea, Neotoma, 64, 88. Ochotona, 76, 94.

Citellus, buxtoni, 73, 92 .

grammurus rupestris, 73,92 .

stejnegeri, 73, 92 .

stonei, $73,92$.

cocalensis, Rhipidomys, 79, 96.

Coendou quichua richardsoni, 80, 96.
Coendou sanctæmartæ, 75, 93.

coibensis, Molossus, 74, 93.

colborni, Ctenomys, 73, 92.

colimæ, Sigmodon, 65, 88.

colombiana, Lutra, 75, 93.

colombianus, Akodon, 68, 90.

Metachirus nudicaudatus, 69, 90.

colombica, Didelphis karkinophaga, 69, 90.

columbianus, Oreamnos montanus, 74, 92.

conditi, Perognathus, 63, 87.

Conepatus nicaraguæ, 78, 95.

confinis, Lepus arizonæ, 66, 89.

consobrinus, Tamias minimus, 59, 85 .

Scotophilus castaneus, 76, 94.

constablei, Phenacomys, 68, 89.

coreanus, Ochotona, 79, 96.

costaricensis, Blarina, 60, 86.

Oryzomys, 62, 87.

Reithrodontomys, 63, 87.

couesi, Tylomys, 62, 86.

Crocidura kijabæ, 77, 95.

Ctenomys colborni, 73, 92.

osgoodi, 75,94 .

robustus, 73,92 .

sericeus, 73, 92 .

cucutæ, Sciurus gerrardi, 81, 97.

Cynomys parvidens, 76, 94.

dacotensis, Sciurus hudsonicus, $63,87$.

Dactylomys peruanus, 69, 90.

Dama lichtensteini, 71, 91.

Dasyprocta fuliginosa candelensis, 82, 98. variegata chocoensis, 82,98 . variegata urucuma, $82,98$. variegata zamoræ, $82,98$.

Dasypterus ega punensis, 81, 97.

daulensis, Molossus, 83, 99. Sylvilagus, 81, 97.

delicatus, Oryzomys, 65, 88 .

Dermonotus suarpurensis, 74, 93.

deserti, Reithrodontomys megalotis, 63, 87.

Didelphis paraguayensis andina, 72, 91. karkinophaga caucæ, 69, 90. karkinophaga colombica, 69, 90. marsupialis etensis, 72, 91. marsupialis insularis, 72, 91. 
Didelphis paraguayensis meridensis, 72, 91.

richmondi, 70, 91.

pernigra, 69, 90.

marsupialis tabascensis, 70, 91 .

marsupialis texensis, 70, 91 .

yucatanensis, 70, 91.

Didelphys canescens, 62, 87 .

difficilis, Vesperimus, 60, 86.

Dipodops ordii palmeri, 60, 86 .

—_ richardsoni, 60, 86.

sennetti, 60, 86.

dorsalis, Peramys brevicaudatus, 74, 93.

dubius, Peromyscus, 66, 89.

duida, Callicebus lugens, 81, 97.

Sciurus, 81, 97.

durangæ, Eutamias, 73, 92.

- Lepus, 73， 92.

Myotis californicus, 73, 92.

Neotoma intermedia, 73, 92.

dychei, Reithrodontomys, 63, 87.

Echimys canicollis, 68, 90.

mincæ, 68, 90.

trinitatis, 62, 84 .

urichi, 68, 90.

elenæ, Margay tigrina, 82, 98.

Eligmodontia morgani, 70, 91.

emiliæ, Ecomys, 83, 99.

engelhardti, Marmota, 76, 94.

Eptesicus andinus, 81, 97.

chapmani, 82, 98.

eremicus, Lepus texianus, 63, 87.

Erethizon godfreyi, 75, 93.

epixanthus nigrescens, 73, 92 .

Erinaceus orientalis, 73, 92.

escuinapæ, Heteromys pictus, 76, 94 . Lynx ruffus, 73, 92.

esmeraldæ, Myotis, 81, 97.

etensis, Didelphis marsupialis, 72, 91.

Euneomys petersoni, 73, 92.

Eunothocyon, 75, 84.

Eutamias adsitus, 76, 94.

albogularis, 77, 95 .

canescens, 74, 93 .

durangæ, 73, 92 .

lectus, 75, 94 .

Evotomys fuscodorsalis, 62, 68, 84.

jochelsoni, 73, 92.

letastei, 73, 92 . exiguus, Peromyscus, 66, 89.

Felis carrikeri, 74, 93.

maripensis, 74, 93.

mearnsi, 74, 93.

panamensis, 74, 93.

sanctæmartæ, 74, 93.

femoralis, Perognathus, 60, 86.

figginsi, Ochotona, 79, 96.

flaccidus, Peromyscus texanus, 73, 92.

florenciæ, Cholœpus, 80, 96.

Microsciurus, 81, 97.

Ecomys, 83, 98.

floridanus, Lepus sylvaticus, 59, 85 .

fossor, Thomomys, 61,88 .

frater, Tamias, 59, 85 .

fraterculus, Zygodontomys, 80, 97.

frustrator, Akodon, 65, 88.

fulvescens, Reithrodontomys mexicanus, 63, 87.

Sylvilagus, 79, 96.

fulvirostris, Oryzomys, 79, 96.

fulviventer, Oryzomys, 68, 90. Sigmodon, 58, 85 .

fumeus, Ototylomys, 77, 95.

Funambulus ruidonensis, 76, 94 .

furvus, Peromyscus, 66, 89.

fusca, Chilonycteris rubiginosa, 78, 95.

fuscata, Mazama, 82, 98.

fuscatus, Æpeomys, 79, 96.

- Heteromys, 77, 94.

fuscodorsalis, Evotomys, 62, 87.

fuscogriseus, Metachirus, 69, 90.

gabbi, Bassaricyon, 52, 84 .

Lepus brasiliensis, 55, 85.

gaumeri, Adelonycteris, 66, 89 .

- Heteromys, 65, 88.

Geomys cherriei, 62, 87.

geronimensis, Peromyscus, 66, 89.

Phoca richardii, 72, 91.

gichiganus, Lepus, 73, 92.

gichigensis, Phoca hispida, 72, 91.

gilberti, Sitomys, 61, 86 .

Glossophaga apolinari, 82, 98.

godfreyi, Erethizon, 75, 93.

gracilis, Reithrodontomys mexicanus, $65,88$.

Tamias quadrivittatus, 59, 85 .

grahamensis, Sciurus hudsonicus, 63, 87.

grangeri, Lepus sylvaticus, 64,87 . 
grangeri, Neotoma, 63, 87.

granti, Rangifer, 71, 91.

graysoni, Lepus, 55, 85.

Gressigrada, 83.

griscescens, Metachirus, 70, 91.

griseimembra, Guerlinguetus, 81, 97.

griseus, Sigmodon hispidus, 77, 95.

Zygodontomys, 80, 97.

gualea, Mazama, 82, 98.

Guerlinguetus candalensis, 81, 97.

griseimembra, 81, 97.

hoffmanni manavi, 81, 97.

hoffmanni quindianus, 81, 97.

pucherani salentensis, $81,97$. æstuans venustus, 82, 98.

guianæ, Tapirus terrestris, 83, 99.

Hadrosciurus, 82, 84.

hainana, Ratufa gigantea, 76, 94 .

hainanus, Atherurus, 76, 94.

Paradoxurus larvatus, 77, 95.

Rhinolophus, 76, 94.

Tamiops macclellandi, 76, 94.

haitiensis, Ardops, 77, 94.

hatcheri, Reithrodon, 73, 92.

helvolus, Oryzomys, 80, 97.

Hesperomys affinis, 60, 86 .

alfaroi, 60,86 .

cherriei, 60, 86 .

nudipes, 60,86 .

Heteromys pictus escuinapæ, 76, 94 .

fuscatus, 77, 94 .

gaumeri, 65,68 .

hispidus, 65, 68 .

jaliscensis, 76, 94 .

jesupi, 68, 90.

lomitensis, 79, 96.

vulcani, 77,94 .

Hipposideros poutensis, 76, 94 .

hispidus, Heteromys, 65, 88.

Histiotus maculatus, 59, 86 .

Histriosciurus, 82, 84 .

Holochilus venezuelensis, 74, 93.

Hoplomys, 77, 84. truei, $77,94$.

huachuca, Sciurus hudsonicus, 63, 87.

hypoleuca, Mycronycteris, 68, 90.

impavidus, Canis, 73, 92.

incautus, Vespertilio, 65, 88.

incertus, Oryzomys alfaroi, 77, 94. incertus, Oryzomys, 80, 97.

ingrahami, Capromys, 60, 86.

inserta, Tayra barbara, 77, 95.

insolitus, Lepus, 59, 85.

insperatus, Arvicola, 63, 87.

instabilis, Tamandua tetradactyla, 75, 93.

insularis, Artibeus, 74, 93.

Didelphis marsupialis, 63, 87.

Sciurus erythræus, 76, 94.

Scotophilus kuhlii, 76, 94.

intermedia, Chœronycteris, 62, 86.

intermedius, Artibeus, 65, 88.

Reithrodontomys mexicanus, $63,87$.

irrara, Tayra barbara, 74, 93.

irazu, Akodon, 74, 93.

Isolobodon, 84, 98. portoricensis, 82, 92 .

Isothrix rufodordalis, $68,90$.

jalapæ, Mus musculus, 66, 89. Oryzomys, 66, 89.

jaliscensis, Heteromys, 76, 94 .

jesupi, Chiroderma, 68, 90.

Heteromys, 68, 90.

jochelsoni, Evotomys, 73, 92.

juliacæ, Oxymycteris, 69, 90.

juruana, Mazama americana, 82, 98.

keaysi, Myotis ruber, 81, 97.

Oryzomys, 69, 91.

Thylamys, 69, 90.

kenaiensis, Ovis dalli, 72, 91.

Ursus americanus, 78, 95.

kermiti, Proechimys, 82, 98.

kijabæ, Crocidura, 77, 95.

kijabeus, Mus, 77, 95.

klagesi, Marmosa, 69, 90.

kodiacensis, Spermophilus parryi, 51, 84 .

kolymensis, Ochotona, 73, 92.

laceyi, Reithrodontomys, 65, 88.

lagunetæ, Nasua olivacea, 80, 96.

langi, Madoqua, 77, 95.

latastei, Evotomys, 73, 92.

latidens, Lutra, 77, 95.

lectus, Eutamias, 76, 94.

Lemmus obensis chrysogaster, 73, 92.

Leptosciurus, 82, 84.

Lepus sylvaticus arizonæ, 55, 85.

aquaticus attwateri, 64,88 . 
Lepus sylvilagus aztecus, 59, 85 . gaillardi battyi, 73, 92 . bishopi, 68, 90 . cerrosensis, 66, 89 . floridanus chapmani, 68, 90 . cinerascens, 59, 85. arizonæ confinis, 66, 89. durangæ, 73, 92. texianus eremicus, 63,87 . sylvaticus floridanus, 59,85 . brasiliensis gabbi, 55, 85 . gichiganus, 73, 92 . sylvaticus grangeri, 64,87 . graysoni, 55, 85 . insolitus, 59, 85 . sylvaticus mearnsi, 62,87 . texianus micropus, 73, 92 . parvulus, 74, 93. peninsularis, 66,89 . americanus phæonotus, 68, 90 . sylvaticus pinetis, 63,87 . russatus, 74, 92. superciliaris, 68, 90 . truei, 59, 85 .

gabbi tumacus, 77,94 .

lichtensteini, Dama, 71, 91.

lomitensis, Heteromys, 79, 96. Melanomys, 80, 96.

Loncheres carrikeri, 78, 95. castaneus, 62,87 .

Lonchophylla thomasi, 74, 93. longimembris, Ateles, 82, 98. lucophæus, Arvicola, 63, 87. luteiventris, Mus, 78, 95. Tamias quadrivittatus, 59, 85. lutescens, Akodon, 70, 91. Lutra colombiana, 75, 93. latidens, 77, 95.

Lynx ruffus escuinapæ, 73, 92. texensis, 64, 87 .

macrodens, Phoca ochotensis, 72, 91. Macrogeomys matagalpæ, 78, 95. maculatus, Histiotus, 59, 86. maculiventer, Oryzomys, 68, 90. Madoqua langi, 77, 95. magdalenæ, Oryzomys, 68, 90. Sciurus saltuensis, 81, 97. manavi, Guerlinguetus hoffmanni, 81, 97. Manis pusilla, 76, 94.
Margay caucensis, 82, 98.

- tigrina elenæ, 82, 98.

maripensis, Felis, 74, 93.

- Myotis, 81, 97.

Marmosa chapmani, 69, 90. klagesi, 69, 90. sinaloæ, 66, 89.

Marmota engelhardti, 76, 94. martirensis, Sitomys, 61, 86. Thomomys fulvus, 66,89 . mascotensis, Sigmodon, 65, 88. matagalpæ, Alouatta palliata, 77, 95.

- Sciurus deppei, 77, 95.

- Macrogeomys, 77, 95. mattogrossæ, Oryzomys, 83, 99. Mazama fuscata, 82, 98. gualea, 82,98 . americana juruana, 82, 98. murelia, 82, 98. cita sanctæmartæ, 82, 98. americana tumatumari, 82, 98. trinitatis, 82,98 . zamora, 82, 98 .

mearnsi, Felis, 74, 93.

- Lepus sylvaticus, 62, 87. Perognathus, 65, 88. Vesperimus, 60, 86.

melanogenys, Meles, 79, 96.

Melanomys beunavistæ, 80, 96 . lomitensis, 80, 96. affinis monticola, 80, 96. caliginosus oroensis, 80,96 . phæopus tolimensis, 80, 96 . phæpus vallicola, 80, 96.

melanotis, Peromyscus, 66, 89.

Meles melanogenys, 79, 96.

meridensis, Akodon, 74, 93.

Didelphis paraguayensis, 72, 91.

merriami, Perognathus, 60, 86 .

Reithrodontomys, 63, 87.

Tamias asiaticus, 58, 85.

Ursus, 72, 91.

Mesosciurus, 82, 84.

gerrardi baudensis, 82, 98 . gerrardi valdivia, 82,98 .

Metachirus nudicaudatus antioquiæ, 82, 98. nudicaudatus bolivianus, 70, 91 . 
Metachirus nudicaudatus colombianus, 69, 90 .

fuscogriseus, 69, 90 . griscesens, 70, 91.

fuscogriseus pallidus, 70,91 . tschudii, 69, 90.

mexicanus, Oryzomys, 65, 88.

Micronycteris hypoleuca, 68, 90.

micropus, Lepus texianus, 73, 92.

Oryzomys, 83, 99.

Microxus affinis, 79, 96.

Microsciurus, 64, 83.

florenciæ, 81, 97.

rubrirostris, $81,97$.

microtis, Oxymycteris, 73, 92.

Putorius, 73, 92.

Microtus cautus, 68, 89.

stonei, 68,89 .

vellerosus, 68,89 .

milleri, Myoprocta, 80, 96 .

- Ecomys, 83, 99.

Pithecia, 81, 98.

Promops, 68, 90.

Reithrodontomys, 79, 96.

Rhipidomys, 80, 97.

Sciurus, 79, 96.

mincæ, Echimys, 68, 90.

Ecomys, 80, 97.

mississippiensis, Canis, 52, 84.

missoulæ, Oreamnos montanus, 74, 92.

modesta, Tupaia, 76, 94.

modestus, Oryzomys, 68, 90.

mollipilosus, Oryzomys, 68, 90.

mollissimus, Rhipidomys, 79, 96 .

Molossus bondæ, 74, 93.

cherriei, 83, 99.

coibensis, 74, 93 .

daulensis, 83, 99 .

sinaloæ, 76, 94 .

verrilli, 77,94 .

monticola, Melanomys affinis, 80, 96 .

monticolus, Thomomys, 61, 86 .

morgani, Eligmodontia, 70, 91.

Mormopterus peruanus, 81, 97.

munchiquensis, Oryzomys, 79, 96.

Mungos palawanus, 78, 95.

rubrifrons, 77, 95 .

murelia, Mazama, 82, 98.

Oryzomys, 82, 98.
Mus andrewsi, 78, 95.

buruensis, 78, 95 .

musculus jalapæ, 66, 99 .

kajabius, 77, 95.

luteiventris, 78, 95 .

Mustela tropicalis nicaraguæ, 82, 98.

Myoprocta milleri, 80, 96.

Myotalpa rufescens, 77, 95.

Myotis bondæ, 86, 97 .

caucensis, 86, 97.

chiriquensis, 74, 93.

californicus durangæ, 73, 92.

esmeraldæ, 86, 97.

ruber keaysi, 86,97 .

maripensis, 86, 97.

nairobæ, Arvicanthis, 77, 95.

Nasua narica bullata, 74, 93 .

olivacea lagunetæ, 80, 96.

narica pallida, 74,93 .

narica panamensis, 74, 93 .

phæocephala, 74, 93.

narica yucatanica, 74, 93.

nasutus, Vesperimus, 60, 96.

Neacomys pusillus, 79, 96 .

nebrascensis, Reithrodontomys dychei, $63,87$.

Nectomys palmipes, 60,86 .

neglectus, Tamias quadrivittatus, 59, 85 .

neomexicanus, Sciurus fremonti, 66, 89.

Neotoma anthonyi, 66, 89.

arenacea, 66, 99 .

campestris, $63,87$.

micropus canescens, 60,86 .

chrysomelas, 77, 94 .

cinnamomea, 64, 88.

intermedia durangæ, 73, 92 .

grangeri, 63,87 .

rupicola, 63,87 .

sinaloæ, 66,89 .

nicaraguæ, Conepatus, 78, 95.

Oryzomys, 78, 95.

Peromyscus, 77, 95.

Mustela tropicalis, 82, 98.

niger, Tayassu, 80, 96.

nigrescens, Blarina, 64, 88.

Erethizon epizanthus, 73, 92.

Notosciurus, 81, 84 .

rhoadsi, 81, 97.

nudipes, Hesperomys, 60, 86 . 
Nyctinomus æquatorialis, 81, 97.

obscurus, Reithrodon cuniculoides, 73, 92.

Perodipus, 73, 92.

Tamias, 59, 85.

obtusirostris, Oryzomys, 69, 91 .

Ochotona cinnamomea, 76, 94. coreanus, 79,96 .

figginsi, 79, 96.

kolymensis, 73, 92 .

ochraceus, Oryzomys, 77, 94.

ochrogaster, Rhipidomys, 70, 91.

o'connelli, Oryzomys, 80, 97. Proechimys, 80, 96.

Odobænidæ, 50, 83.

Odocoileus battyi, 73, 92 . sinaloæ, 73, 92 .

Ecomys caicaræ, 81, 90. emiliæ, 83, 99.

florenciæ, 83, 99.

milleri, 83, 99.

minca, 81, 90.

olivaceus, Blarina, 77, 95.

Spermophilus tridecemlineatus, $64,88$.

Oncoides pardalis tumatumari, 82, 98.

Oreamnos montanus columbianus, 74 , 92.

montanus missoulæ, 74, 92.

orientalis, Erinaceus, 73, 92.

oroensis, Melanomys caliginosus, 80, 96.

orophila, Blarina, 64, 88.

Oryzomys obscurior affinis, 79, 96.

aquaticus, 60,86 .

barbacoas, 82, 98 .

baroni, 66,89 .

baueri, 60,86 .

bolivaris, 70, 91 .

brevicauda, 62,87 .

bulleri, 65,88 .

carrikeri, 77, 94.

castaneus, 70, 91.

cherriei, $64,88$.

chrysomelas, 65, 88.

costaricensis, 62, 87 .

delicatus, 65,88 .

fulvirostris, 79, 96 .

fulviventer, 68,90 .

helvolus, 81, 97.
Oryzomys alfaroi incertus, 77, 94 . incertus, 86, 97.

jalapæ, $66,89$.

keaysi, 69,91 .

maculiventer, 68, 90 .

magdalenæ, 68, 90.

mattogrossæ, 83, 99.

mexicanus, 65,88 .

microtis, 83, 98 .

modestus, 68, 90 .

mollipilosus, 68, 90.

munchiquensis, 79, 96.

mureliæ, 82, 98.

nicaraguæ, 77, 95.

obtusirostris, 69,91 .

ochraceus, 77, 94.

o'connelli, 81, 97.

palmarius, 68, 90 .

palmiræ, 79, 96.

palustris texensis, 62,87 .

pectoralis, 79, 96 .

perenensis, 70, 91.

richardsoni, 77, 95.

rivularis, $70,91$.

sanctæmartæ, 68, 90 .

speciosus, 62,87 .

talamancæ, $60,86$.

tenuicauda, 68, 90 .

tenuipes, 74, 93.

trichurus, 68, 90 .

trinitatis, 62, 87 .

utiaritensis, 83, 99 .

velutinus, 62,87 .

villosus, 68,90 .

vincencianus, 86, 97.

osborni, Rangifer, 72, 91.

osgoodi, Ctenomys, 75, 94.

Amorphochilus schnablii, 81, 97.

osilæ, Phyllotis, 70, 91.

Ototylomys fumeus, 77, 95.

Ouliphocinæ, 50, 83.

Ovis dalli kenaiensis, 72, 91 .

stonei, 65,88 .

storchi, 74, 93.

owstoni, Sciurotamias, 77, 95.

Oxymycterus apicalis, 69, 91.

juliaca, $69,90$.

microtis, 73, 92 . 
Pachycyon, 58, 83.

robustus, 58,83 .

palawanus, Mungos, 78, 95.

pallescens, Peromyscus michiganensis, $65,88$.

pallida, Nasua narica, 74, 93.

pallidus, Metachirus fuscogriseus, 70, 91.

Spermophilus tridecemlineatus, 51,84 .

Tamias quadrivittatus, 51, 84 .

palmarius, Oryzomys, 68, 90.

palmarum, Artibeus, 65, 88.

palmeri, Dipodops ordii, 6C, 86 .

palmipes, Nectomys, 62, 87.

palmiræ, Oryzomys, 79, 96.

panamensis, Felis, 74, 93.

Phyllostoma hastatus, 74, 93. Nasua narica, 74, 93.

Paradoxurus larvatus hainanus, 77, 95.

Paralces, 72, 84.

parvidens, Cynomys, 76, 94.

parvulus, Lepus, 74, 93.

parvus, Spermophilus tridecemlineatus, $64,88$.

paulus, Peromyscus, 73, 92.

pearyi, Rangifer, 72, 91.

pectoralis, Oryzomys, 79, 96.

peninsulæ, Tamias leucurus, 61,86.

peninsularis, Lepus, 66, 89.

Peramys brevicaudatus dorsalis, 74, 93. perenensis, Oryzomys, 70, 91.

perriger, Ursus americanus, 78, 95.

pernigra, Didelphia, 69, 90.

pernix, Perognathus, 66, 89.

Perodipus obscurus, 73, 92.

Perognathus conditi, 63, 87.

femoralis, 60,86 .

mearnsi, 65,88 .

merriami, 60, 86 .

pernix, 66, 89 .

pricei, 63,87 .

Peromyscus attwateri, 64, 68.

banderanus, 65,68 .

musculus brunneus, 66,89 .

cedrosensis, 66,89 .

cineritius, $66,89$.

dubius, 66,89 .

exiguus, 66,89 .

texanus flaccidus, 73, 92.
Peromyscus furvus, 66, 89.

geronimensis, 66,89 .

melanotis, 66, 89 .

nicaraguæ, 77, 95.

michiganensis pallescens, 65,88 .

paulus, 73, 92.

eremicus propinquus, 66,89 .

spicilegus, 65, 68 .

texanus subarcticus, $68,90$.

yucatanicus, 65,68 .

peruanus, Dactylomys, 69, 90.

——— Mormopterus, 81, 97.

Sciurus, 66, 88 .

Sigmodon, 66, 89.

petersoni, Euneomys, 73, 92.

phæocephala, Nasua, 74, 93.

phæonotus, Lepus americanus, 68, 90.

phæurus, Sciurus aberti, 74, 93.

Phenacomys constablei, 68, 89. truei, $63,87$.

Phoca richardii geronimensis, 72, 91. hispida gichigensis, 72, 91 .

ochotensis macrodens, 72, 91 . richardii pribilofensis, 72,91 . stejnegeri, 72,91 .

Phyllostoma hastatus cauræ, 74, 93. hastatus panamensis, 74,93 .

Phyllotis cachinus, 70, 91. chacoensis, 70, 91 . osilæ, 70, 91.

pictus, Tamias minimus, 59, 85 . pinetis, Lepus sylvaticus, 63,87 . Pipistrellus portensis, 76, 94.

Pithecia milleri, 81, 98.

popayanus, Thomasomys, 79, 96 . portensis, Pipistrellus, 76, 94.

portoricensis, Isolobodon, 83.

Potos flavus caucensis, 74, 93.

flavus chapadensis, 74, 93 .

flavus chiriquensis, 74, 93 .

flavus tolimensis, 80, 96.

poutensis, Hipposideros, 76, 94.

pribilofensis, Phoca richardii, 72, 91.

pricei, Perognathus, 63, 87.

- Tamias, 64, 88.

princeps, Zapus, 61,86 .

Procyon xquatorialis, 82, 98. proteus, 74, 93 .

Proechimys, 68, 84. 
Proechimys boimensis, 83, 98.

kermiti, 82, 98.

o'connelli, 80, 96.

Promops affinis, 68, 90.

barbatus, 74, 93 .

milleri, 68, 90.

propinquus, Peromyscus eremicus, 66, 89.

proteus, Procyon, 74, 93.

puna, Sigmodon, 73, 92.

punensis, Dasypterus ega, 81, 97.

Myotis, 81, 97.

Tamandua tetradactyla, 82, 98.

pusilla, Manis, 76, 94.

pusillus, Neacomys, 79, 96.

Putorius microtus, 73, 92.

pygmæus, 73, 92.

pygmæus, Putorius, 73, 92.

quebradensis, Sciurus, 68, 90.

quindianus, Guerlinguetus hoffmanni, 81, 97.

Rhipidomys, 81, 97.

Rangifer granti, 71, 91.

osborni, $72,91$.

pearyi, $72,91$.

stonei, $70,91$.

terranovæ, $65,88$.

Ratufa gigantea hainana, 76, 94 .

Reithrodon hatcheri, 73, 92. cuniculoides obscurus, 73, 92.

Reithrodontomys arizonensis, 63, 87. mexicanus aurantius, 63,87 . australis, 64, 88 .

aztecus, 61,86 .

megalotis deserti, 63, 87 .

dychei, 63, 87.

costaricensis, 63, 87 .

mexicanus fulvescens, 61,87 .

mexicanus gracilis, 65, 68 .

mexicanus intermedius, $63,87$.

laceyi, 65,88 .

merriami, 63,87 .

milleri, 79, 96 .

dychei nebrascensis, 63, 87 .

rufescens, 66,89 .

saturatus, 66, 89 .

megalotis sestinensis, 73, 92 .

tenuis, 68,90 .
Reptigrada, 83.

Rhinolophus hainanus, 76, 94.

- Rhipidomys caucensis, 80, 97. cocalensis, 79, 96 . milleri, 80, 97. mollissimus, 79, 96 . ochrogaster, 70, 91. quindianus, $80,97$. similis, 79, 96 . venezuelæ yuruanus, 80, 97.

rhoadsi, Notosciurus, 81, 97. richardsoni, Artibeus jamaicensis, 77, 95. Bassaricyon, 77, 95.

Coendou quichua, 80, 96.

Dipidops, 60, 86.

Oryzomys, 77, 95.

richmondi, Didelphis, 70, 91.

riudonensis, Funambulus, 76, 94.

riudoni, Tamiops macclellandi, 76, 94 .

rivularis, Oryzomys, 70, 91.

robustus, Ateles, 81, 98.

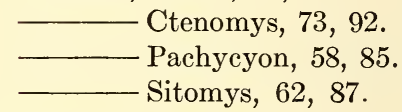

roosevelti, Cacajao, 81, 98.

rowleyi, Sitomys, 61,86 .

rubicunda, Alouatta seniculus, 75, 93.

rubrifrons, Mungos, 77, 95.

rubrirostris, Microsciurus, 80, 97.

rufescens, Myotalpa, 77, 95.

Reithrodontomys, 66, 89.

rufodorsalis, Isothrix, 68, 90.

rupestris, Citellus grammurus, 73, 92 .

rupicola, Neotoma, 63, 87.

rusbyi, Artibeus, 74, 93.

russatus, Lepus, 74, 92.

Saimiri caquetensis, 82, 98 .

salaquensis, Sciurus gerrardi, 81, 97.

salentensis, Guerlinguetus pucheranii, 81, 97.

salentus, Sylvilagus, 80, 96 .

saltator, Zapus, 68, 89.

sanctæmartæ, Coendou, 74, 93.

Felis, 74, 93.

Mazama cita, 82, 98.

Oryzomys, 68, 90.

saturatus, Reithrodontomys, 66, 89.

sauteri, Tamiops, 78, 95.

Scalops argentatus texanus, 60,86 . 
Scapanus anthonyi, 61, 86.

Sciurotamias owstoni, 77, 95.

Sciurus douglasii albolimbatus, 66, 89 .

$$
\begin{aligned}
& \text { alfari, } 64,88 . \\
& \text { alstoni, } 58,85 . \\
& \text { apache, } 61,86 . \\
& \text { hudsonicus baileyi, } 66,89 \text {. } \\
& \text { aberti barberi, } 74,90 . \\
& \text { beebei, } 78,95 . \\
& \text { saltuensis bondæ, } 68,90 .
\end{aligned}
$$$$
\text { hudsonius californicus, 59, } 85 \text {. }
$$$$
\text { campestris, 63, } 87 \text {. }
$$$$
\text { douglasii cascadensis, 66, } 89 \text {. }
$$$$
\text { cervicalis, 59, } 85 \text {. }
$$$$
\text { chapmani, } 68,90 \text {. }
$$$$
\text { gerrardi cucutæ, 81, } 97 .
$$$$
\text { duida, 81, } 97 .
$$$$
\text { hudsonicus grahamensis, } 63,87 .
$$
arizonensis huachuca, $63,87$. erythræus insularis, 76, 94 . saltuensis magdalenæ, 81, 97. deppei matagalpæ, 77, 95. milleri, 79, 96.

fremonti neomexicanus, 66,89 . peruanus, 66,88 .

aberti phæurus, 74, 93. quebradensis,' 68,90 . gerrardi salaquensis, 81, 97. langsdorffii steinbachi, 81, 97. hudsonicus streatori, 66, 88. poliopus tepicanus, 76,94 . langsdorffii urucumus, 81, 97. hudsonius vancouverensis, 59, 85.

hudsonicus ventorum, 66,88 . wagneri, $67,89$.

igniventris zamoræ, $81,97$. zarumæ, 81, 97.

sclateri, Canis, 75, 94.

Scotophilus castaneus consobrinus, 76, 94.

kuhlii, 76, 94.

senex, Tamias, 59, 85.

senilis, Tayra barbara, 80, $96 . \quad$.

sennetti, Dipodops, 60, 86.

sericeus, Ctenomys, 73, 92.

sestinensis, Reithrodontomys megalotis, 73, 92.

Sigmodon baileyi, 73, 92 .
Sigmodon baroni, 66, 89 .

bogotensis, 66, 88 .

borucæ, 65,88 .

borucæ chiriquensis, 74, 93 .

chonensis, 80, 96.

colimæ, 65, 88.

fulviventer, 58, 85 .

hispidus griseus, 77, 95 .

mascotensis, 65,88 .

peruana, 66, 88 .

puna, 73,92 .

simonsi, 69, 91.

vulcani, 76,94 .

Sigmodontomys, $65,84,88$. alfari, $65,84,88$.

similis, Rhipidomys, 79, 96.

simonsi, Sigmodon, 69, 91.

Simosciurus, 82, 84 .

sinaloæ, Marmosa, 66, 89.

Molossus, 76, 94.

Neotoma, 66, 89.

Odocoileus, 73, 92.

Sitomys americanus arizonæ, 63, 87 .

auripectus, 61, 86.

gilberti, 61,86 .

robustus, 62,87 .

rowleyi, 61,86 .

americanus thurberi, 61, 86.

Sorex buxtoni, 73, 92 .

speciosus, Oryzomys, 62, 87.

Spermophilus parryi kodiacensis, 51, 84 . tridecemlineatus olivaceus, 64 , 88.

tridecemlineatus pallidus, 51, 84.

tridecemlineatus parvus, 64,88 .

spicilegus, Peromyscus, 65, 88.

Squalodon tiedemani, 58, 85.

squamipes, Blarina, 79, 96.

steinbachi, Sciurus langsdorffii, 81, 97.

stejnegeri, Citellus, 73, 92.

- Phoca, 72, 91.

stonei, Citellus, 73, 92

Microtus, 68, 89.

Ovis, 65, 88.

Rangifer, 70, 91.

storcki, Ovis, 74, 93.

streatori, Sciurus hudsonicus, 66, 89 .

suarpurensis, Dermonotus, 74, 93. 
subarcticus, Peromyscus texanus, 68, 90 . superciliaris, Lepus, 68, 90. .

Sylvilagus boyleyi, 82,98 . daulensis, 81, 97. fulvescens, 81, 97 . salentus, 80, 96.

Synaptomys andersoni, 73, 92. chapmani, 73, 92.

tabascensis, Didelphis marsupialis, 70, 91.

talamancæ, Oryzomys, 60, 86.

Tamandua tetradactyla chapadensis, 75 , 93.

tetradactyla chiriquensis, 75 , 93.

tetradactyla instabilis, 75, 93. tetradactyla punensis, 82,98 . tetradactyla tenuirostris, 75, 93 .

Tamias quadrivittatus affinis, 59, 85. amœnus, 59, 85 . asiaticus borealis, 55, 85 . asiaticus bulleri, 58,85 . cinereicollis, 59, 85 . minimus consobrinus, 59,85 . frater, 59, 85 . quadrivittatus gracilis, 59, 85 . asiaticus merriami, 58, 85 . quadrivittatus neglectus, 59, 85.

obscurus, 59,85 .

quadrivittatus pallidus, 51, 84 . leucurus peninsulæ, 61,86 . minimus pictus, 59,85 . pricei, 64, 88 . wortmani, 64,88 .

Tamiops, 76, 84 .

macclellandi hainanus, 76, 94 . macclellandi ruidoni, 76, 94 . sauteri, 78, 95 .

tapirapoanus, Zygodontomys, 83, 99. Tapirus terrestris guianæ, 83, 99.

Tayassu niger, 80, 96.

Tayra barbara inserta, 77, 95 . barbara irara, 74, 93. barbara senilis, 80, 96. tenuicauda, Oryzomys, 68, 90. tenuipes, Oryzomys, 74, 93. tenuirostris, Tamandua tetradactyla, 72 , 93. tenuis, Reithrodontomys, 68, 90 . tepicanus, Sciurus poliopus, 76, 94 . terrænovæ, Rangifer, 65, 88. texanus, Scalops argentatus, 60,86 . texensis, Didelphis marsupialis, 70, 91. Lynx, 64, 87. Oryzomys palustris, 62, 97. thomasi, Lonchophylla, 74, 93. Zygodontomys, 69, 91.

Thomasomys fulvus alticolus, 68, 90. fulvus anitæ, 66,84 . atrovarius, 66, 89 . aureus altorum, 81,97 . aureus, 61,86 . cervinus, $64,87$. cinereiventer, 79, 96. fossor, 61,86 . fulvus martirensis, 66, 89 . monticolus, 61,86 . popayanus, 79, 96 . toltecus, 61,86 .

Thrinacodus apolinari, 81, 97. thurberi, Sitomys americanus, 61,86 . Thylamys carri, 65, 88 . keaysi, 69, 90 .

tiedemani, Squalodon, 58, 85. tjaderi, Tragelaphus, 77, 95 . tolimæ, Akodon, 80, 96.

Melanomys phæopus, 80, 96. tolimensis, Potos flavus, 80, 96. toltecus, Thomomys, 61,86 . Tragelaphus tjaderi, 77, 95. Trichophocinæ, 83. trichurus, Oryzomys, 68, 90. trinitatis, Echimys, 62, 87. Mazama, 82, 98. Oryzomys, 62, 87 .

truei, Hoplomys, 77, 94. Lepus, 59, 85. Phenacomys, 61, 87. tschudii, Metachirus, 69, 90. tucumanensis, Akodon, 70, 91. tumacus, Lepus gabbi, 77, 94. tumatumari, Mazama, 82, 98. Oncoides pardalis, 82, 98.

Tupaia modesta, 76, 94.

Tylomys couesi, 62,87 .

umbrinus, Tamias, 59, 85.

urichi, Akodon, 65, 88 
urichi, Echimys, 68, 90.

Urocyon cinereoargentea venezuelæ, 78, 95.

Urosciurus, 82, 84.

Ursus americanus kenaiensis, 78, 95. merriami, 72, 91 . americanus pernigra, 78, 95 .

utiaritensis, Oryzomys, 83, 99.

urucuma, Dasyprocta variegata, 82, 98. urucumus, Sciurus langsdorffii, 81, 97. valdivia, Mesosciurus gerrardi, 82, 98 . vallicola, Melanomys phæopus, 80, 96. vancouverensis, Sciurus hudsonius, 59, 85.

velifer, Vespertilio, 59, 85.

vellerosus, Microtus, 68, 89.

velutinus, Oryzomys, $62,87$.

venezuelæ, Cavia porcella, 78, 95.

Urocyon cinereoargentea, 78, 95.

venezuelensis, Akodon, 68, 90.

Holochilus, 74, 93.

ventorum, Sciurus hudsonicus, 66, 89.

venustus, Guerlinguetus æstuans, 82, 98.

verrilli, Molossus, 76, 94.

Vesperimus difficilis, 60,86 . mearnsi, 60,86 .
Vespertilio chrysonotus, $65,88$. incautus, $65,88$. velifer, 59,85 .

villosus, Oryzomys, 68, 90.

vulcani, Heteromys, 77, 94. Sigmodon, 76, 94.

Vulpes anadyrensis, 73, 92. wagneri, Sciurus, 67, 89. whitei, Arctictis, 78, 95. whitneyi, Cervus, 52, 84 . wortmani, Tamias, 64,88 . yucatanensis, Didelphis, 70, 91. yucatanica, Nasua narica, 74, 93. yucatanicus, Artibeus, 74, 93. Peromyscus, 65, 88.

yuruanus, Rhipidomys, 80, 97 . zamora, Mazama, 82, 98.

zamoræ, Dasyprocta variegata, 82, 98. Sciurus igniventris, 81, 97.

Zapus princeps, 61, 86 . saltator, 68, 89 .

zarumæ, Sciurus stramineus, 81, 97.

Zygodontomys, 83.

fraterculus, 86, 97.

griseus, 86, 97 .

tapirapoanus, 83, 99.

thomasi, 69, 91. 



\title{
II. BIRDS.
}

\author{
$1860-62$.
}

1. Birds of New England. <New England Farmer (weekly), for Aug. 11, 25, Sept. 22, Oct. 6, 20, Nov. 3, 17, Dec. 1, 22, 1860; Jan. 5, 26, March 2, May 18, June 15, July 20, Sept. 21, Oct. 26, Nov. 23, 1861; April 26, July 26, Aug. 16, Sept. 13, Oct. 18, 25, Nov. 8, Dec. 6, 1862. Also, published in the same newspaper (monthly), large 8vo, for Sept., Oct., Nov., Dec., 1861, January, March, May, June, July, Sept., Nov., Dec., 1862, and Jan., 1863.

"Twenty-five articles in all, taking the birds of New England in order from Accipitres to the middle of the Fringillidæ. Popular bingraphical accounts, written to interest farmers in the feathered life of their fields."- (Coues, "Bibliography of North American Ornithology,' in 'Birds of the Colorado Valley,' 1878, p. 661.)

1864.

2. Catalogue of the Birds found at Springfield, Mass., with Notes on their Migrations, Habits, etc.; together with a List of those Birds found in the State not yet observed at Springfield. < Proc. Essex Inst., IV, art. iv, pp. 48-98, August, 1864.

“ 195 spp. at Springfield; 296 in Massachusetts, of which 131 breed, 28 are resident, 67 winter visitors, 75 migrants, 106 summer visitors, 35 stragglers." - (Coues, l. c., p. 667.)

1865 .

3. Notes on the Habits and Distribution of the Duck Hawk, or American Peregrine Falcon (Falco peregrinus), in the Breeding Season, and Description of the Eggs [from Mt. Tom, Mass.]. <Proi. Essex Inst., IV, (for 1864) 1865, art. x, pp. 153-161. (Communicated Nov. 14, 1864.)

1867.

4. Winter Notes of an Ornithologist.<Amer. Nat., I, pp. 38-48, March, 1867.

Relates to the winter birds of Massachusetts - 55 to 60 spp., consisting mainly of permanent residents and visitors from the North. Comment on their manner of occurrence and relative abundance.

5. The Birds of Spring. <Amer. Nat., I, pp. 141-144, May, 1867.

Relates mainly to New England - 280 species there at the season named; contains a tabular summary.

6. Ornithological Calendars [for March, April, and May].<Amer. Nat., I, p. 54 [for March], p. 109 [for April], p. 160 [for May], March-May, 1867.

Dates of usual appearance of migratory birds in Massachusetts in the spring months.

1868.

7. Notes on Birds observed in Western Iowa, in the months of July, August and September; also on birds observed in Northern Illinois in May and June, and 
at Richmond, Wayne Co., Indiana, between June third and tenth. $<M e m$. Boston Soc. Nat. Hist., I, pt. iv, art. xiii, pp. 488-526, Dec., 1868 (read June, 1868).

"Very full: includes some critical commentary on geographical distribution in general, and on relationships of certain disputed species. Iowa, $108 \mathrm{spp}$; Illinois, $a$, Ogle Co., $84 \mathrm{spp}$.; $b$, Cook Co., 94 spp., with monographic account of certain Turdidæ; Indiana, 72; the annotations in each case chiefly field-notes.

" "Range in the breeding-season must form the basis for defining the limits of different ornithological districts.... Among migrants of the same species the examples which arrive in the spring the earliest are bigger and more brightly tinted than those which come later, and, conversely, on their return the examples last seen are bigger than the summer specimens.' Hence it would appear that the largest individuals are those which go furthest north in summer, and, he also adds, are those which live further north in winter. Some characteristics of the ornithological provinces of North America are next briefly mentioned; and then follow the lists of species observed, as stated in the title. In Iowa about 108 or 110 species were seen, of which at least 100 breed in the State. For Illinois two lists are given, one of 84 species in Ogle County, the other of 94 species in Cook County. At Richmond 72 species were observed by himself and Dr. Haymond. Some critical notes on supposed species (Turdidæ, Laridæ) are added in the course of the paper."-Coues, l. c., p. 676, quoting A. Newton, Zool. Rec. for 1868, p. 676.

8. [Abstract of a paper on the Birds of Iowa and Illinois, with special reference to their migration.] < Proc. Boston Soc. Nat. Hist., XII, 1868, p. 85.

See the full memoir cited above, No. 7 .

9. Circular in reference to obtaining data concerning the distribution of North American birds in the breeding season. <Ann. Report Trustees of Mus. Comp. Zoölogy for 1868 (1869), pp. 26-27.

Originally issued June 4, 1868. Signed L. Agassiz, but instigated and written by J. A. Allen.

9a. Notes on the Red and Mottled Owls. <Amer. Nat., II, pp. 327-329, August, 1868.

On the red and gray phases of Scops asio, and incidental reference to the question of whether there is more than a single species of the genus Scops in North America.

10. The "Dwarf Thrush" again.<Amer. Nat., II, pp. 488-489, Nov., 1868.

With reference to a former article in this journal by E. A. Samuels on this subject.

11. 'Natural History of Birds.' <Amer. Nat., II, pp. 554-555, Dec., 1868.

Review of Miss Grace Anna Lewis's work of this title (12mo, Philadelphia, 1868).

1869.

12. Philadelphia Vireo and Yellow-bellied Flycatcher.<Amer. Nat., III, p. 504, Nov., 1869.

Brief history of these two species, in reply to inquiries of a correspondent (W. L. T., Minneapolis, Minn.).

\section{9-70.}

13. Notes on some of the Rarer Birds of Massachusetts. <Amer Nat., III, Dec., 1869, pp. 505-519; Jan. and Feb., 1870, pp. 568-585, 631-648.

" 315 species ( $c f$. footnote, p. 647) in Massachusetts. The paper is supplementary to the author's Massachusetts catalogue published five years before in Proc. Essex Inst.; it contains critical comments on the rarer or less generally known species, and discusses the cases of some doubtful ones. The supposed Buteo 'cooperi' proved to be lineatus."- (Coues, l. c., p. 682.) 
1870.

14. Occurrence of the Brown Pelican [Pelecanus fuscus] in Massachusetts. $<A$ mer. Nat., IV, p. 58, March, 1870.

15. What is the "Washington Eagle"?<Amer. Nat., IV, pp. 524-527, Nov. 1870.

Identified as the young of Haliaëtus leucocephalus.

16. Catalogue of the Birds of Iowa. <White's Geolog. Survey of Iowa, Vol. II, 1870, Appendix B, pp. 419-427. (Des Moines, Iowa, 8vo, pp. viii, 443.)

"Nominal list of 283 spp., those actually observed to breed within the limits of the State being marked with asterisk. A few of the species are to be regarded rather as stragglers, chiefly winter visitors from the North; some, however, from the West and South."- (Coues, l. c., p. 682.)

17. Summer Red Bird [Pyranga astiva]. Amer. Nat., IV, p. 56, March, 1870.

Its occurrence at Amherst, Mass.

18. The Ruby-crowned Kinglet. Amer. Nat., IV, p. 54, March, 1870.

The red crown-patch absent in the female.

\section{1.}

19. The Fauna of the Prairies [of the United States].<Amer. Nat., V, pp. 4-9, March, 1871.

Mention of various birds, p. 6 .

20. Classification of Water Birds. <Amer. Nat., IV, pp. 746-752, Feb., 1871.

An extended synoptical review of Dr. E. Coues's paper on this subject (Proc. Acad. Nat. Sci. Philadelphia, 1869, pp. 193-218).

21. The Migration of Hawks. <Amer. Nat., V, p. 173, May, 1871.

Confirmation of Dr. William Wood's observations (Amer. Nat., Feb. 1871, p. 759) on the migration of hawks, namely in loose straggling flocks.

22. On the Mammals and Winter Birds of East Florida, with an Examination of certain assumed Specific Characters in Birds, and a Sketch of the BirdFaunæ of Eastern North America.<Bull. Mus. Comp. Zoöl., II, No. 3, pp. 161-450, pll. iv-viii, April, 1871.

"Part I, The Topographical, Climatic and Faunal characteristics of East Florida. (Part II, On Mammals.) Part III, On Individual and Geographical Variation among Birds, considered in respect to its bearing upon the value of certain assumed specific characters - a highly important philosophic treatise upon the general subject, which is discussed at length with force and logical consistency; the author's broad views upon this subject had at once a marked influence upon ornithological thought. Variation in general size and proportion of parts, both individual and climatic, are illustrated with numerous tables of measurements. An cssay on species and varieties follows. Part IV, List of the Winter Birds of East Florida, with annotations, - field-notes, measurements, and much synonymy and technical criticism. Part V, On the Geographical Distribution of the Birds of Eastern North America, with special reference to the number and circumscription of the Ornithological Faunæ. After general introductory remarks, the natural Provinces of the North American Temperate Region are discussed, and the Ornithological Faunæ of the Eastern Provinces are treated. The following Faunæ are laid down and characterized:-1. Floridan. 2. Louisianian. 3. Carolinian. 4. Alleghanian. 5. Canadian. 6. Hudsonian. 7. American Arctic. Various tabular summaries follow, with general remarks on the distribution and migration 
of the birds of the Eastern Province. A copious bibliography of American Ornithological literature concludes. The plates illustrate the variation in the bill of many species. The article gained the Humboldt Scholarship, and is one of the most important of American ornithological works. Cf. Ibis, 1872, pp. 189-191; Zool. Rec. for 1871, pp. 24, 25; Am. Nat., V, 1871, pp. 364-373."- (Coues, l. c., p. 686.)

1872.

23. Birds of Kansas. <Amer. Nat., VI, pp. 359-360, June, 1872.

Review of first edition of F. H. Snow's Birds of Kansas (8vo, 1872, pp. 8), calling attention to errors and adding 18 species to the list.

24. Prof. Snow's List of Kansas Birds. <Amer. Nat., VI, pp. 483-484, August, 1872.

In reply to criticism by Dr. T. M. Brewer of the former notice of the first edition of Prof. Snow's list. (Cf. supra, No. 23.)

25. Birds of Kansas. <Amer. Nat., VI, p. 765, Dec., 1872.

Notice of the second edition of F. H. Snow's List of Kansas Birds. (8vo, pp. 16, Oct. 1872). Commended as "a highly valuable and creditable list of the Birds of Kansas."

26. Geographical Variation in North American Birds. <Proc. Boston Soc. Nat. Hist., XV, pp. 212-219, Dec., 1872.

In amplification of a previous verbal communication. (Reprinted in Amer. Nat., VIII, pp. 534-541, Sept. 1874.)

27. Notes on the Natural History of Fort Macon, N. C., and Vicinity. <Amer. Nat., VI, pp. 546-549, Sept., 1872.

A review of E. Coues's paper in Proc. Acad. Nat. Sci. Philadelphia, 1871, pp. 12-49, 120148.

28. The Birds of the Tres Marias and Socorro Islands.<Amer. Nat., VI, pp. 681682, Nov., 1872.

A review of A. J. Grayson's paper (edited by G. N. Lawrence), in Proc. Boston Soc. Nat. Hist., XIV, 1872, pp. 261-303.

29. Ornithological Works in Prospect.<Amer. Nat., VI, pp. 478-482, Aug., 1872.

Anticipatory notices of E. Coues's 'Key to North American Birds,' 'Birds of North America,' by S. F. Baird, T. M. Brewer, and R. Ridgway, and of C. J. Maynard's 'Birds of Florida.'

30. Ornithological Blunders. <Amer. Nat., VI, pp. 303-304, May, 1872. (Anonymous.)

Comment on the case of Bonasa jobsii Jaycox, suggesting palliating circumstances.

31. [Geographical Variation in North American Birds.]<Proc. Boston Soc. Nat. Hist., XV, 1872, pp. 156-159. (An editorial abstract is given in Amer. Nat., VIII, 1874, pp. 534-541).

32. Catalogue of the Penguins in the Museum of the Boston Society of Natural History.<Amer. Nat., VI, pp. 545-546, Sept., 1872.

A review of A. Hyatt's paper (Proc. Boston Soc. Nat. Hist., XIV, 1872, pp. 237-251).

33. Notes of an Ornithological Reconnaissance of Portions of Kansas, Colorado, Wyoming, and Utah.<Bull. Mus. Comp. Zoöl., III, No. 6, pp. 113-183, July $10,1872$. 
"After general introductory, the author gives:-1. List of Birds observed at Fort Leavenworth and Topeka, Kansas, spring of 1871 (121 spp.); 2. At Fort Hays, Kansas, May-July, 1871 (61 spp.); 3. In Northwestern Kansas, Dec. 1871, Jan., 1872 (25 spp.); 4. At Cheyenne, Wyoming, Aug. 1871 (41 spp.); 5. In Colorado, July-August, 1871 (81 spp.); 6. In South Park, Colorado, July, 1871 (54 spp.); 7. On Mount Lincoln, Colorado, July, 1871 (36 spp.); 8. Ogden, Utah, Sept.-Oct., 1871 (137 spp.); 9. General Summary or Combination of all the Observations (228 spp.). Besides the extended fieldnotes, there is much critical annotation. The article is very complete, and highly interesting from its bearing on general questions."-(Coues, l. c., pp. 689-690.)

34. Ornithological Notes from the West.<Amer. Nat., May, June, July, 1872, pp. 263-275, 342-351, 394-404.

I, Notes on the Birds of Kansas, pp. 263-275; II, Notes on the Birds of Colorado, pp. 342-351; III, Notes on the Birds of the Great Salt Lake Valley, pp. 394-404. Field notes on the species observed, with brief sketches of the country traversed. (See above, No. 33, for the more formal report on the species observed.)

1873.

35. Monograph of the Spheniscidæ. <Amer. Nat., VII, pp. 38-40, Jan., 1873.

Review of E. Coues's 'Material for a Monograph of the Spheniscidæ' (Proc. Acad. Nat. Sci. Philadelphia, 1872, pp. 170-212).

36. The Birds of Florida. <Amer. Nat., VII, pp. 165-166, March, 1873.

A review of Part I, of C. J. Maynard's work of this title (4to, pp. 32, Salem, 1872).

37. A Text Book of North American Ornithology.<Amer. Nat., VII, pp. 308-309, May, 1873.

A review of E. Coues's 'Key to North American Birds,' first edition.

38. Revision of the American or Tyrant Flycatchers. <Amer. Nat., VII, pp. 35-38, Jan., 1873.

Extended review of E. Coues's 'Studies of the Tyrannidæ. Part I' (Proc. Acad. Nat. Sci. Philadelphia, 1872, pp. 58-81, July, 1872).

39. Crows and Ravens. <Amer. Nat., VII, pp. 743-744, Dec., 1873.

In reference to their supposed antagonism. It is stated that the author had found both crows and ravens together over portions of Dakota and Montana, both frequent and breeding in the same forests.

40. Recent Contributions to American Geographical Ornithology.<Amer. Nat., VII, pp. 361-364, June, 1873.

Review of Holden and Aiken's 'Notes on Birds of Wyoming and Colorado Territories' (Proc. Boston Soc. Nat. Hist., XV, pp. 193-210, Dec., 1872), W. D. Scott's 'Partial List of the Summer Birds of Kenawha County, West Virginia' (ibid., pp. 219-228, Jan., 1873), and T. Martin Trippe's 'Notes on the Birds of Southern Iowa' (ibid., pp. 229-242, March, 1873).

41. The White-fronted Owl in Canada. <Amer. Nat., VII, pp. 427-428, July, 1873.

On Nyctale albifrons Cassin ( $=N$. acadica juv.); its rarity in comparison with the adult ( $N$. acadica) noted, and evidence cited that this supposed species is rightly considered to be the young of $N$. acadica.

42. Notes on the Natural History of Portions of Dakota and Montana Territories, being the substance of a report to the Secretary of War on the Collections 
made by the North Pacific Railroad Expedition of 1873, Gen. D. S. Stanley, Commander. <Proc. Boston Soc. Nat. Hist., XVII, 1874, pp. 33-86. Also separately published, 8vo, Boston, 1874, pp. 1-61.

“III, Report on the Birds, pp. 44-68. 118 spp., fully annotated, the list preceded by general considerations of the avifauna of the region. and several partial local lists. An important contribution."-(Coues, l. c., p. 699.)

43. Field Ornithology. <Amer. Nat., VIII, pp. 418-420, July, 1874.

A review of E. Coues's work of this title (8vo, Salem and Boston, 1874).

44. Laws of Geographical Variation in North American Mammals and Birds. $<$ Amer. Nat., VIII, pp. 227-229, April, 1874.

In reference to R. Ridgway's article (Amer. Nat., VII, 1873, pp. 548-555), and making definite claim for certain original generalizations on this subject. (See also Coues, op. cit., pp. $41 j-421)$.

1875 .

45. [Exhibition of a Specimen of the Sharp-tailed Finch from Illinois.]<Proc. Boston Soc. Nat. Hist., XVII, 1875, pp. 292-295.

First description of Ammodramus caudacutus var. nelsoni, and the first new form of bird described by the author.

46. Influence of Elevation and Latitude upon the Distribution of Species. <Amer. Nat., IX, pp. 181-182, March, 1875.

47. Coues's Birds of the Northwest.<Atlantic Monthly, XXXVI, pp. 365-368, Sept., 1875.

Review of the work (8vo, 1874, U. S. Geol. and Geogr. Surv. Terr., Miscel. Pub. No. 3).

48. Dr. Coues's 'Birds of the Northwest.' < Amer. Nat., IX, pp. 466-468, Aug., 1875. Review of the work.

49. 'Birds of the Northwest.' < Rod and Gun, VI, May 22, 1875, p. 119.

A letter of comment upon the criticisms of Dr. Elliott Coues's 'Birds of the Northwest, by a previous contributor.

1876.

50. Exploration of Lake Titicaca, by Alexander Agassiz and S. W. Garman. III List of Mammals and Birds. By J. A. Allen, with Field-notes by Mr. Garman. <Bull. Mus. Comp. Zoöl., III, pp. 349-359, July, 1876.

An annotated list of 69 spp. of birds, pp. 353-359. Falcinellus ridgwayi, Gallinula garmani, spp. nov.

51. Progress in Ornithology in the United States during the last Century. $<A m e r$. Nat., X, pp. 536-550, Sept., 1876.

An enumeration, with comment, of the principal works and papers of the previous century (1776-1876), followed by a 'Sunmary of Progress.'

52. The Availability of certain Bartramian Names in Ornithology. <Amer. Nat., X, pp. 21-29, Jan., 1876.

In reference to Dr. E. Coues's attempted revival of sundry Bartramian names for birds in his 'Fasti Ornithologiæ Redivivi. No. I' (Proc. Acad. Nat. Sci. Philadelphia, 1875, pp. $338-358)$. 
53. Bartramian Names Again: An Explanation. <Amer. Nat., X, pp. 176, 177, March, 1876.

Explanation of a misconception of the position assumed by his critic in Coues's rejoinder (Amer. Nat., X, Jan. 1876, pp. 98-102) to 'The Availability of Certain Bartramian Names.' (Cf. supra, No. 52).

54. Ornithological Calendar for March. <Forest and Stream, VI, p. 84, Mar. 16, 1876.

55. Calendar for Birds in Massachusetts, March 20-31.<Forest and Stream, VI, p. 116, March 30, 1876.

56. Calendar [for Birds in Massachusetts for April 1-20.] < Forest and Stream, VI, p. 132, April 6, 1876.

57. Send in the Reports. <Forest and Stream, VI, p. 115, March 30, 1876.

On the importance of securing data on the migrations and habits of birds, with suggestions to observers. (See also supra, No. 9, on this subject.)

58. The Extinction of the Great Auk at the Funk Islands. <Amer. Nat., X, p. 48, Jan., 1876.

59. Geographical Variation in the Number and Size of the Eggs of certain North American Birds. <Bull. Nutt. Ornith. Club, I, pp. 74-75, Sept., 1876.

Southern representatives of northern species lay smaller eggs, and also a smaller number of eggs.

60. Decrease of Birds in Massachusetts. <Bull. Nutt. Ornith. Club, pp. 53-60, Sept., 1876.

Statement of the case, and discussion of the causes, special reference being made to the Great Auk, Pinnated Grouse, Wild Turkey, Wild Pigeon, Swans, Cranes, Geese, etc.

61. Breeding of the Canada Goose [Bernicla canadensis] in trees. $<$ Bull. Nutt. Ornith. Club, p. 50, July, 1876.

62. Anser [Chen] rossii in Oregon. <Bull. Nutt. Ornith. Club, I, p. 52, July, 1876. Secured at Camp Harney, Oregon, by Capt. Charles Bendire.

63. Occurrence of the Wood Ibis [Tantalus loculator] in Pennsylvania and New York. <Bull. Nutt. Ornith. Club, I, p. 96, Nov., 1876.

64. Field and Forest. <Bull. Nutt. Ornith. Club, I, p. 71, Sept., 1876.

Notice of Vol. II, No. 1, the only ornithological article it contains being on Wilson's Phalarope by L. Kumlien.

65. The Birds and Coming Storms. <Forest and Stream, VI, No. 9, p. 133, April 6, 1876.

66. Descriptions of New Species of American Birds. <Bull. Nutt. Ornith. Club., I, p. 47, July, 1876.

Notice of two recent papers by G. N. Lawrence in Ann. Lyc. Nal. Hist. New York, XI, pp. 163-166, and Ibis, July, 1875, pp. 383-387.

67. Notes on the Breeding Habits of Clarke's Crow (Picicorvus columbianus), with an account of its Nest and Eggs. <Bull. Nutt. Ornith. Club, I, pp. 44-46, July, 1876. 
Compiled from letters from Capt. Charles Bendire and published over his name, with explanatory and other comment.

68. The Birds of Kansas. <Bull. Nutt. Ornith. Club, I, pp. 47-48, July, 1876.

Notice of F. H. Snow's third edition of his 'A Catalogue of Kansas Birds' (8vo, pp. 14, Nov. 1875).

69. Extinct Birds with Teeth. <Bull. Nutt. Ornith. Club, I, p. 49, July, 1876.

Notice of O. C. Marsh's papers on Ichthyornis, Apatornis, Hesperornis, Lestornis, in Amer. Journ. Sci., 1875 and 1876.

70. Life-Histories of the Birds of Eastern Pennsylvania. <Bull. Nutt. Ornith. Club, I, pp. 49-50, July, 1876.

Review of Vol. I of T. G. Gentry's work of this title (12mo, Philadelphia, 1876).

71. Decrease of Birds in the United States. <Penn. Monthly, pp. 931-944, Dec., 1876.

Their present numbers, particularly waterfowl and shore-birds, contrasted with the numbers recorded in the accounts of conditions in the 17 th century.

72. The Birds of Ritchie County, Virginia. < Bull. Nutt. Ornith. Club, I, p. 72, Sept., 1876. 146).

Brief notice of William Brewster's paper (Ann. Lyc. Nat. Hist. New York, XI, pp. 129-

73. Birds of Southwestern Mexico. <Bull. Nutt. Ornith. Club, I, p. 93, Nov., 1876.

Brief notice of G. N. Lawrence's paper on F. E. Sumichrast's collection (Bull. U. S. Nat. Mus., No. 4, 1876).

74. Jordan's Manual of Vertebrate Animals. <Bull. Nutt. Ornith. Club, I, pp. 93-94, Nov., 1876. 1876).

Review of the first edition of this well-known work by David Starr Jordan (12mo, Chicago,

75. The Portland Tern [Sterna portlandica]. <Bull. Nutt. Ornith. Club, I, pp. 71-72, Sept., 1876.

Notice of William Brewster's paper on the "so-called Sterna portlandica," which he considers an unusual phase of Sterna macroura (Ann. Lyc. Nat. Hist. New York, XI, pp. 200207, Feb. 18, 1876).

76. Sexual, Individual, and Geographical Variation in Leucosticte tephrocotis. $<$ Bull. U. S. Geol. and Geogr. Surv. Terr., II, No. 4, July, 1876, pp. 345-350.

A "considerable constant sexual variation in coloration and also.... in size," overlooked by R. Ridgway in his monograph on the genus Leucosticte (Bull. U. S. Geol. and Geogr. Surv. Terr., No. 2, 2d ser., May, 1875).

77. Sexual Variation in the Genus Leucosticte. $<$ Field and Forest, II, No. 5, pp. 7679, Nov., 1876.

A rejoinder to Mr. Ridgway's reply to criticisms of his Monograph of the Genus Leucosticte. (Cf. supra, No. 76).

\section{7.}

78. Recent Ornithological Papers. <Amer. Nat., XI, pp. 615-617, Oct., 1877.

Reviews of Nelson's paper on Illinois Birds in Bull. Essex Inst., VIII, 1877, pp. 90-155, and IX, pp. 32-65; McCauley's on Texas Birds, in Bull. U. S. Geol. and Geogr. Surv. Terr., III, 1877, 655-695, and others. 
79. Californian Ornithology. <Bull. Nutt. Ornith. Club, II, p. 76, July, 1877.

Review of Dr. J. G. Cooper's paper 'New Facts relating to Californian Ornithology' (Proc. California Acad. Sci., 1876).

80. McCauley's Notes on Texan Ornithology. <Bull. Nutt. Ornith. Club, II, p. 76, July, 1877.

Review of Lieut. C. A. H. McCauley's paper (Bull. U. S. Geol. and Geogr. Surv. Terr., III, No. 3, pp. 655-695, May 15, 1877).

81. Occurrence of the Western Nonpareil [Cyanospiza versicolor], and Berlandier's Wren [Thryothorus ludovicianus var. berlandieri] at Fort Brown, Texas. < Bull. Nutt. Ornith. Club, II, No. 4, pp. 109-110, Oct., 1877.

Based on information furnished by Dr. J. C. Merrill.

82. Ridgway's "Studies of the American Falconidæ." < Bull. Nutt. Ornith. Club, II, pp. 70-73, July, 1877.

Review of several of R. Ridgway's papers on this family, in Bull. U. S. Geol. and Geogr. Surv. Terr., Proc. Acad. Nat. Sci. Philadelphia, and Proc. Boston Soc. Nat. Hist.

83. List of Birds collected by Mr. Charles Linden, near Santarem, Brazil. $<$ Bull. Essex Inst., VIII, No. 8, 1876, pp. 78-83. (Pub. Feb., 1877).

Annotated list of 128 spp.; Coccygus lindeni, sp. nov.

84. The Influence of Physical Conditions in the Genesis of Species. <Radical Review, I, pp. 108-140, May, 1877.

On the influence of environment in modif ying forms of mammals and birds, and discussion of Darwin's theory of the origin of species by natural selection. Reprinted (by request), with slightly modernized nomenclature by the author, in Ann. Rep. Smiths. Institution for 1905 (1906).

1878.

85. Maynard's Birds of Florida. <Bull. Nutt. Ornith. Club, III, p. 145, July, 1878.

Notice of Part IV of C. J. Maynard's "Birds of Florida," etc. (4to, Newtonville, Mass., pp. 89-112, one pl.). The full title now employed is "The Birds of Florida, with the Water and Game Birds of Eastern North America.'

86. Jordan's Manual of Vertebrated Animals. <Bull. Nutt. Ornith. Club, III, pp. 145-146, July, 1878.

Brief notice of the $2 \mathrm{~d}$ ed., revised and enlarged (1878). (Cf. supra, No. 74.)

87. The Carolinian Fauna. <Bull. Nutt. Ornith. Club, III, July, 1878, pp. 149-150.

Apropos of Eugene Bicknell's paper (Bull. Nutt. Ornith. Club, III, pp. 128-132) and continuing the subject (northward extension into the lower Hudson River valley).

88. Brewer's Supplement to his Catalogue of New England Birds. <Bull. Nutt. Ornith. Club, III, p. 185, Oct., 1878.

Review of paper by Dr. T. M. Brewer (Proc. Boston Soc. Nat. Hist., XIX, pp. 301-309), which adds 21 spp. to his 'Catalogue of the Birds of New England' published in 1875.

89. Elliot's Review of the Ibidinæ, or Ibises. <Bull. Nutt. Ornith. Club, III, p. 182, Oct., 1878.

Review of D. G. Elliot's paper of this title (Proc. Zool. Soc. London, 1877, pp. 477-510). 
90. [The Glossy Ibis, Ibis falcinellus, in Massachusetts.]<Bull. Nutt. Ornith. Club, III, p. 152, July, 1878.

Note, following a record of this species in Massachusetts by C. B. Cory, on the occurrence of two other individuals on Cape Cod at about the same time. Also a foot-note on the correct generic name of the bird, which is stated to be Plegadis Kaup. (Cf. Ibis, 4th ser., II, Jan., 1878, p. 112).

91. A list of the Birds of Massachusetts, with Annotations. <Bull. Essex Inst., X, pp. $3-37,1878$.

"This may be considered to supercede previous tracts on the same subject, both by the present and other authors, as it completely sums our knowledge of the subject. The paper opens with summary considerations, followed by a valuable historical résumé. 1. Species of authentic occurrence within the State, 317. 2. Extirpated, 4. 3. Of probable occurrence, 24. 4. Hypothetical and doubtful species, 3 (Myiodioctes minutus, Empidonax pygmæus of Minot, Thaumatias linnæi). 5. Introduced undomesticated species, 6.'Considered as fairly entitled to recognition as Massachusetts birds,' 340 . Known to breed in the State, about 135. Extremely rare or accidental visitors, 90. North American species added since 1867, 35." - (Coues, l. c., p. 736).

92. Sabine's Gull [Xema sabinii] in Maine. <Bull. Nutt. Ornith. Club, III, p. 195, Oct., 1878.

The only previous New England record for this species is Boston Harbor, Mass., Sept. 24, 1874 (Brewster, Amer. Sportsman, V, 1875, p. 370; Brewer, Proc. Boston Soc. Nat. Hist., XVII, 1875 , p. 449.

93. Occurrence of three Species of Sea-Ducks [Edemia americana, EE. fusca, $E$. perspicillata] at St. Louis, Missouri. <Bull. Nutt. Ornith. Club, III, pp. 148149, July, 1878.

94. Description of a Fossil Passerine Bird from the Insect-bearing Shales of Colorado. <Bull. U. S. Geol. and Geogr. Surv. Terr., IV, No. 2, May 3, 1878, art. xix, pp. 443-445, pl. 1, figg. 1, 2.

"Palæospiza bella, g. sp. n., p. 443 - the first fossil Passerine discovered in North America. It bcars distinct impressions of feathers. N. B. - a few copies of this No. of the Bull. were in private circulation from about April 14, and some electros of the plate were sent out during this month. Thus, the cut appeared in a Californian newspaper [Cf. infra, No. 117 ] with a compiled account of the bird, April 27. The article was immediately reprinted in the $A m$. Journ. Sci., for May, 1878."- (Coues, l. c., p. 738). The type specimen, lost for many years was recovered in 1915 .

95. Birds of the Vicinity of Cincinnati. <Bull. Nutt. Ornith. Club, III, p. 34, Jan., 1878.

Review of F. W. Langdon's 'Catalogue of the Birds of the Vicinity of Cincinnati' (8vo, Salem, 1877, pp. 18).

96. Rowley's 'The Pied Duck [Camptolomus labradorius].' <Bull. Nutt. Ornith. Club, III, pp. 79-80, Apr., 1878.

Review of G. D. Rowley's Monograph (Orn. Miscel., II, pt. vii, 1877).

97. Barrows's 'Catalogue of the Alcidæ.' < Bull. Nutt. Ornith. Club, III, p. 86, Apr., 1878.

Brief review of W. B. Barrows's his paper of this title (Proc. Boston Soc. Nat. Hist., XIX, 1877 , pp. 150-165).

98. Ridgway's 'Studies of the American Herodiones.' <Bull. Nutt. Ornith. Club, III, pp. 182-183, Oct., 1878. 
Review of R. Ridgway's paper in Bull. U. S. Geol. and Geogr. Surv. Terr., IV, pp. 219-251, Feb. 5, 1878 .

99. Reichenow's Review of the Herons and their Allies. $<$ Bull. Nutt. Ornith. Club, III, pp. 183-185, Oct., 1878.

Extended review of Dr. Anton Reichenow's 'Uebersicht der Schreitvögel,' in Cabanis's Journ. für Ornith., Jahrg. XXV, Apr.-July, 1877, pp. 113-171, 225-278.

100. An Inadequate 'Theory of Birds' Nests.' < Bull. Nutt. Ornith. Club, III, pp. 2332, Jan., 1878.

A criticism of A. R. Wallace's 'Theory of Birds' Nests.'

101. Late Capture of the Yellow-bellied Flycatcher [Empidonax flaviventris] in Massachusetts. <Bull. Nutt. Ornith. Club, III, pp. 101-102, Apr., 1878.

Nov. 29, and Dec. 1, 1876 - two records.

102. The Lark-Bunting [Calamospiza bicolor] in Massachusetts. $<$ Bull. Nutt. Ornith. Club, III, p. 48, Jan., 1878.

First record of the capture of this species east of the Mississippi River.

103. Rufous-headed Sparrow [Peuccea ruficeps] in Texas. $<$ Bull. Nutt. Ornith. Club, III, pp. 188-189, Oct., 1878.

Gainesville, Texas, April 24, 1878, collected by George H. Ragsdale.

104. The Snow-Bird [Junco hyemalis] in Summer on Mount Wachusett, Mass. $<$ Bull. Nutt. Ornith. Club, III, p. 192, Oct., 1878.

On the authority of Bradford Torrey.

105. Early Nesting of the Shore Lark [Eremophila alpestris] near Indianapolis, Ind. <Bull. Nutt. Ornith. Club, III, p. 189, Oct., 1878.

Young birds half-grown April 24, 1878. Based on information communicated by David S. Jordan (in lit.).

106. Ridgway's Ornithology of the Fortieth Parallel. <Amer. Nat., XII, p. 469, July, 1878.

Review of the work (Expl. 40th Parallel, IV, pt. iii, 4to, 1877).

107. Sharpe's 'Catalogue of the Birds in the British Museum.' <Bull. Nutt. Ornith. Club, III, pp. 77-79, Apr., 1878.

Review of Volume I, 1874 (Falconidæ), Volume II, 1875 (Strigidæ), and Vol. III, 1877 (the Coliomorphæ - Crows, Birds of Paradise, Orioles, etc.).

108. [Pipilo erythrophthalmus with white spots on the Scapulars.] $<$ Bull. Nutt. Ornith. Club, III, p. 42, Jan., 1878.

Taken near Leavenworth, Kansas.

109. Summer Birds of the Adirondacks. <Bull. Nutt. Ornith. Club, III, p. 36, Jan., 1878.

Notice of T. Roosevelt and H. D. Minot's paper (8vo, 1877, pp. 4, privately printed.)

110. Birds of Central New York.<Bull. Nutt. Ornith. Club, III, pp. 34-35, Jan., 1878.

Review of F. B. Rathbun's List, in Auburn Daily Advertiser, Aug. 14, 1877. 
111. Birds of Southern Illinois. <Bull. Nutt. Ornith. Club, III, p. 36, Jan., 1878.

Review of E. W. Nelson's paper (Bull. Essex Inst., IX, pp. 32-65, June, 1877).

112. Gentry's 'Life-Histories of the Birds of Eastern Pennyslvania.' < Bull. Nutt. Ornith. Club, III, pp. 36-37, Jan., 1878.

Review of Vol. II, of this work (cf. supra, No. 70).

113. Street's Notes on the Birds of Lower California and the Hawaiian and Fanning Islands. <Bull. Nutt. Ornith. Club, III, pp. 80-81, April, 1878. 1877).

Review of Dr. Thomas H. Street's paper in Bull. U. S. Nat. Mus., No. 7 (birds, pp. 9-33,

114. Bendire's Notes on the Birds of Southeastern Oregon. $<$ Bull. Nutt. Ornith. Club, III, p. 81, April, 1878.

Review of Capt. Charles Bendire's paper in Proc. Boston Soc. Nat. Hist., XIX, 1877, pp. 109-149.

115. Ridgway's Report on the Ornithology of the Fortieth Parallel. $<$ Bull. Nutt. Ornith. Club, III, pp. 81-83, April, 1878.

Review of R. Ridgway's 'Ornithology' in Vol. IV, Part iii, Explor. 40th Parallel, pp. 303670, 1877. (Cf. supra, No. 106.)

116. Feilden's 'List of Birds Observed in Smith Sound,' etc. $<$ Bull. Nutt. Ornith. Club, III, p. 86, April, 1878.

Review of H. W. Feilden's paper (Ibis, 4th ser., I, 1877, pp. 401-412).

117. A Remarkable Fossil Bird. [Palocospiza bella Allen] <Pacific Rural Press (newspaper), April 27, 1878. Vol. XV, No. 17, p. 257, fig.

"Anonymous, but contributed to the paper by the U. S. Geological Survey. It is an abstract of the orig. account, accompanied by an electro, and actually antedates the regular publication of the article by six days."--Coues, l.c., p.738. (Cf. supra, No. 94.)

118. The Nuttall Ornithological Club. <Boston Journal, Mar. 19, 1878.

" A dignified and well-considered defence of the Club from the attacks made in the article entitled 'History Repeating Itself,' and elsewhere. 'Neither the ideas, the similes, nor the phraseology of the article are new, having done service repeatedly in other Boston papers within a few weeks in a similar connection. Therefore the inference is natural, that they have emanated, either directly or indirectly, from a single source. The article in question is simply a presentation, in connected form, of the various anonymous squibs that have appeared repeatedly in other papers.... Unfortunate, indeed, is it if this purely practical and scientific question cannot be discussed on its merits, and that the defenders of the [English] sparrows must confess their weakness by a persistent resort to such unsafe weapons as misrepresentation and ridicule."'-Coues, 'On Present Status of Passer domesticus,' etc., in Bull. U. S. Geol. and Geogr. Surv. Terr., V, 1879, p. 185).

119. The Nuttall Ornithological Club.<Evening Transcript, Mar. 21, 1878.

"A defence of the Club, which has been referred to contemptuously as a body of "Cambridge juveniles," "precocious boys," “over-modest youths," etc., including a statement of its organization and operations, and the real character of its membership. T. M. Brewer is mentioned as a member, and a contributor to the Bulletin of the Club."-Coues, $l$. $c$.

120. The Nuttall Ornithological Club. Sketch of our Cambridge Ornithological Society.<Cambridge Chronicle, March 30, 1878. 
121. Nuttall Ornithological Club. Sparrows [Passer domesticus].-The Nuttall Ornithological Club decides against them. <Boston Daily Advertiser, CXXXI, No. 47, Feb. 23, $1878 . \quad$ (Anonymous.)

"The inside history of this article is: Some time about January, 1878, Dr. Brewer was in my office in Washington, where some words on the subject grew a little heated toward the close of the interview, when I proposed that it would be well to ask the Nuttall Club to take up and sif the matter, that we might get at the facts, if possible. The reply was complimentary neither to the sincerity of my proposition nor to the ornithological ability of the Club, of which he was a member. I soon af terward addressed to the Club a communication inviting their attention to the matter, suggesting a full and fair discussion of the subject in open meeting, and representing that the Club was specially well qualified to come to just conclusions, consisting, as it did, of a number of working ornithologists of recognized ability and experience, who were perf ectly familiar with the case as presented in Boston, Cambridge, and vicinity. The meeting was soon af ter held. Notice was sent to the resident members of the proposed consideration of the question, and corresponding members were also invited to take part in the discussion. Dr. Brewer for some reason did not attend the meeting. The report of the meeting, constituting the present article, indicates that Mr. J. A. Allen, Mr. William Brewster, Mr. H. A. Purdie, Mr. H. D. Minot, Mr. Ruthven Deane, and others, participated in the discussion. Mr. Allen's views are not here presented. All the testimony here reported is unfavorable to the Sparrows, but need not be here analyzed, as it is only what every competent and unprejudiced observer knows; it is explicit, emphatic, and irrefragable, substantiating every count that has been brought against the birds. The article includes an open letter to Dr. Brewer from John Dixwell, M. D., stating that in 39 individuals, taken at the height of the canker-worm pest, no trace of insect food could be found on dissecting; the publication of which letter gave offence to Dr. Brewer, who considered it an unwarrantable liberty to take with his name. At the close of the discussion a vote was taken on the question of whether or not, in the opinion of those present, the further increase of the house sparrow in this country was desirable. The result was a unanimous negative." Coues, $l$. $c$.

122. Nuttall Ornithological Club. Sparrows [Passer domesticus] brought to Judgment. Discussion of the Nuttall Ornithological Club upon the Merits and Demerits of the English Sparrow in the United States. <The Country (newspaper of New York), pp. 245-246, Feb. 23, 1878.

"This is the full report of the meeting, communicated officially by the Club, occupying nearly two pages ( 5 columns). It gives much matter additional to that published in the Boston Daily Advertiser, and is especially important in presenting at length views of J. A. Allen, and in including communications from Mr. R. Ridgway and Dr. C. C. Abbott, not given in the Boston report of the proceedings. Allen's carefully considered testimony, though well guarded, is, emphatically and explicitly, against the Sparrows. 'Mr. Allen further stated, that every ornithologist of note throughout the country who has expressed himself upon the subject (and nearly all have done so) has, almost without exception, declared against the Sparrows. Not a few of them consider their rapid increase an alarming evil, which will soon call for legislative action to hold it in check." - Coues, l. c.

123. The Sparrows [Passer domesticus].<Evening Transcript, Mar. 19, 1878. H. A. Purdie.)

"Covering a copy of The Country of February 23, 1878, which contained the full report of the Nuttall Club's proceedings, Mr. J. A. Allen's testimony having been omitted from the report as published in Boston. Mr. Allen's testimony follows."-Coues, $l$. $c$.

124. [Range of the Fish Crow in New York and New England]. $<$ Bull. Nutt. Ornith. Club, II, p. 47, Jan., 1878.

125. Persistency in Nest-building by a Pair of City Robins [Turdus migratorius]. $<$ Bull. Nutt. Ornith. Club, III, pp. 103-104, Apr., 1878.

Rebuilt their nest five times when it was removed by a human friend of the birds, owing to the unsafe nature of the site on account of cats. 
1879.

126. Notes on the Sea-Birds of the Grand Banks.<Bull. Nutt. Ornith. Club, IV, pp. 127-128, April, 1879.

Based mainly on letters from Raymond L. Newcomb.

127. Lawrence and Ober on the Birds of Dominica and St. Vincent. $<$ Bull. Nutt. Ornith. Club, IV, pp. 48-49, Jan., 1879.

Notices of five of G. N. Lawrence's papers on F. A. Ober's collections in the Lesser Antilles, in Ann. New York Acad. Sci., and Proc. U. S. Nat. Mus., 1878.

128. Elliot's Synopsis of the Trochilidæ. <Bull. Nutt. Ornith. Club, IV, pp. 230-232, Oct., 1879.

D. G. Elliot's 'A Classification and Synopsis of the Trochilidæ' (4to, Smiths. Inst., 1879).

129. Nest and Eggs of the Cerulean Warbler [Dendroeca cœrulea]. <Bull. Nutt. Ornith. Club, IV, pp. 25-27, Jan., 1879.

130. Odd Behavior of a Robin [Turdus migratorius] and a Yellow Warbler (Dendræca œstiva]. <Bull. Nutt. Ornith. Club, IV, pp. 178-182, July, 1879.

131. Brewer on the Nests and Eggs of Empidonaces. <Bull. Nutt. Ornith. Club, IV, p. 232, Oct., 1878.

Review of Dr. T. M. Brewer's paper (Proc. U. S. Nat. Mus., Vol. I, 1879).

132. Belding and Ridgway's Birds of Central California. <Bull. Nutt. Ornith. Club, IV, July, 1879, pp. 167-171.

Review of L. Belding and R. Ridgway's 'A Partial List of the Birds of Central California' (in Proc. U.S. Nat. Mus., I, April, 1879), with remarks on methods of designating "incipient species." including a history of the evolution and adoption of the trinomial system in the United States.

133. The Evening Grosbeak [Hesperiphona vespertina] in New Mexico. $<$ Bull. Nutt. Ornith. Club, IV, p. 237, Oct., 1879.

134. Birds of the Colorado Valley. <The Nation, March 20, 1879. (Anonymous.)

Review of Dr. Coues's 'Birds of the Colorado Valley,' 8vo, 1878.

135. Birds of the Southwest. $<$ Science News, I, pp. 81-84, Jan. 15.

Review of Dr. Coues's 'Birds of the Colorado Valley.'

1880.

136. Roberts on the Convolution of the Trachea in the Sandhill and Whooping Cranes [Grus canadensis and G. americana].<Bull. Nutt. Ornith. Club, V, pp. 179-180, July, 1880.

Short notice of T. S. Roberts's paper (Amer. Nat., XIV, 1880, pp. 108-114).

137. The Tennessee Warbler [Helminthophaga peregrina] destructive to Grapes. $<$ Bull. Nutt. Ornith. Club, V, p. 48, Jan., 1880.

138. Eastward Range of the Western Meadow Lark [Sturnella magna neglecta]. $<$ Bull. Nutt. Ornith. Club, V, pp. 53-54, Jan., 1880.

To central and western Iowa, southern Michigan, and northwestern Illinois. 
139. [Note on Chordeiles popetue minor in Florida]. $<$ Bull. Nutt. Ornith. Club, V, p. 54, Jan., 1880.

Note to Mr. Greene Smith's record under this title.

140. The King Eider [Somateria spectabilis] at Buffalo, N. Y. <Bull. Nutt. Ornith. Club, V, pp. 62-63, Jan., 1880.

141. On recent additions to the Ornithological Fauna of North America. $<$ Bull. Nutt. Ornith. Club, V, pp. 85-92, April, 1880.

The additions, formally listed, with references to places of original record, number 38 , with an introductory 'Retrospective' of $4 \mathrm{pp}$.

142. A Crossbilled Horned Lark [Eremophila alpestris.]<Bull. Nutt. Ornith. Club, V, p. 115, April, 1880.

143. [Note on a Loggerhead Shrike (Lanius ludovicianus) taken in Northern New York.]<Bull. Nutt. Ornith. Club, V, p. 119, April, 1880.

144. Capture of Escaped Cage-birds having the Appearance of Wild Birds. $<$ Bull. Nutt. Ornith. Club, V, pp. 119-121, April, 1880.

Records for various exotic species, with comment.

145. Note on the Little Brown Crane (Grus fraterculus Cassin). $<$ Bull. Nutt. Ornith. Club, V, pp. 123-124, April, 1880.

Comparison of a specimen taken in eastern Mexico with specimens of Grus canadensis.

146. Destruction of Birds by Light-houses. <Bull. Nutt. Ornith. Club, V, pp. 131138, July, 1880.

Statistics of migrating birds killed by lighthouses.

147. Origin of the Instinct of Migration in Birds. <Bull. Nutt. Ornith. Club, V, pp. 151-154, July, 1880.

Attributed to change of climate at the close of the Tertiary period. "What was at first a forced migration would soon become habitual, and through the heridity of habit give rise to that wonderful faculty we term the instinct of migration" (p. 153).

148. List of the Birds of the Island of Santa Lucia, West Indies. <Bull. Nutt. Ornith. Club, V, pp. 163-169, July, 1880.

Annotated list of $56 \mathrm{spp.;} \mathrm{first} \mathrm{record} \mathrm{for} \mathrm{the} \mathrm{island} \mathrm{of} 16$ species.

149. First Capture of the Blue Grosbeak [Goniaphea cærulea] in Massachusetts. $<$ Bull. Nutt. Ornith. Club, V, p. 184, July, 1880.

150. Capture of a South American Finch [Gubernatrix cristatella] near Providence, R. I. <Bull. Nutt. Ornith. Club, V, p. 240, Oct., 1880.

In perfect plumage, showing no sign of previous captivity.

151. Coues's Bibliography of American Ornithology. <Bull. Nutt. Ornith. Club, V, pp. 40-41, Jan., 1880.

Review of the Second Instalment (Faunal Publications relating to Central and South America), in Bull. U. S. Geol. and Geogr. Surv. Terr., V, pp.'239-330, Sept., 1879. Also mention of the same author's paper 'On the Present Status of Passer domesticus in America,' etc., op. cit., pp. 175-193. 
152. Ridgway on the Species of the Genera Scops and Tyrannus, etc. $<$ Bull. Nutt. Ornith. Club, V, pp. 41-42, Jan., 1880.

Review of four papers by R. Ridgway in Proc. U. S. Nat. Mus., 1878.

153. MeChesney's Notes on the Birds of Fort Sisseton, Dakota Territory. $<$ Bull. Nutt. Ornith. Club, V, pp. 42-43, Jan., 1880.

Review of Dr. Chas. E. McChesney's paper of this title in Bull. U. S. Geol. and Geogr. Surv. Terr., V, 1879, pp. 71-104.

154. Minor Ornithological Publications. <Bull. Nutt. Ornith. Club, V, Jan., 1880, pp. 43-46; April, 1880, pp. 112-115; July, 1880, pp. 180, 181.

Brief notices of 54 papers in Forest and Stream, Field and Forest, and Forest and Stream (Nos. 1-54). Continued in subsequent volumes of the Nuttall Bulletin and The Auk till 1887. The record begins with the close of that given by Dr. Coues in his 'List of Faunal Publications relating to North American Ornithology,' published in his 'Birds of the Colorado Valley,' or about July, 1878. (Cf. infra, Nos. 178, 181, 192, 200, 205, 214, 218.)

155. Henshaw's Report on Collections made in California, Nevada, and Oregon in 1877-78<Bull. Nutt. Ornith. Club, V, pp. 105-107, April, 1880.

Review of H. W. Henshaw's report in Rep. U. S. Geogr. Surv. West of 100th Meridian, App. L, pp. 282-335, Feb. 1880.

156. Cory's Birds of the Bahamas Islands. <Bull. Nutt. Ornith. Club, V, p. 107, April, 1880.

Review of Chas. B. Cory's book of this title (4to, Boston, 1880).

157. Brewer's Additional Notes on New England Birds. <Bull. Nutt. Ornith. Club, V, pp. 108-109, April, 1880.

Review of Dr. T. M. Brewer's supplemental list, in Proc. Boston Soc. Nat. Hist., XVII, pp. $436-454$.

158. Kumlien's Contributions to the Natural History of Arctic America. $<$ Bull. Nutt. Ornith. Club, V, pp. 109-110, April, 1880.

Review of the bird portion of Ludwig Kumlien's 'Contributions to the Natural History of Arctic America,' etc. (Bull. U. S. Nat. Mus., No. 15, 1879; Birds, pp. 69-105).

159. Gibbs's List of the Birds of Michigan. <Bull. Nutt. Ornith. Club, V, p. 110, April, 1880.

Review of Dr. Morris Gibbs's 'Annotated List of the Birds of Michigan' (Bull. U. S. Geol. and Geogr. Surv. Terr., V, No. 3, Nov. 1879).

160. Harvie-Brown on the Capercaillie in Scotland. <Bull. Nutt. Ornith. Club, V, pp. 110-111, April, 1880.

Review of J. A. Harvie-Brown's 'The Capercaillie in Scotland' (8vo, Edinburgh, 1879).

161. Sennett's 'Further Notes on the Birds of the Lower Rio Grande of Texas.' $<$ Bull. Nutt. Ornith. Club, V, p. 111, April, 1880.

Review of George B. Sennett's second paper on Texas Birds (Bull. U. S. Geol. and Geogr. Surv. Terr., V, 1879, pp. 371-440).

162. Minot's Diary of a Bird.<Bull. Nutt. Ornith. Club, V, p. 112, April, 1880.

Review of H. D. Minot's 'The Diary of a Bird' (8vo, Boston, 1880).

163. Freke on Birds common to Europe and North America. <Bull. Nutt. Ornith. Club, V, pp. 173-174, July, 1880. 
BIRDS.

Review of 'A Comparative Catalogue of Birds found in Europe and North America' by Percy Evans Freke (8vo, Dublin, 1880).

164. Brayton's Catalogue of the Birds of Indiana. <Bull. Nutt. Ornith. Club, V, pp. 174-175, July, 1880.

Review of Dr. A. W. Brayton's paper on Indiana birds, in Trans. Indiana Hort. Soc. for 1879 , pp. $89-166$ (1880).

165. Mearns's Birds of the Hudson Highlands. <Bull. Nutt. Ornith. Club, V, p. 175, July, 1880.

Review of Dr. E. A. Mearns's 'List of the Birds of the Hudson Highlands,' in Bull. Essex Inst., Vols. X, XI, 1879-80.

166. Harvie-Brown and Cordeaux's 'Report on the Migration of Birds in the Autumn of 1879.' < Bull. Nutt. Ornith. Club, V, pp. 175-176, July, 1880.

Review of their paper in The Zoologist, May, 1880, pp. 161-204.

167. Ridgway on the Nomenclature of North American Birds. <Bull. Nutt. Ornith. Club, V, pp. 177-178, July, 1880.

Review of his 'Revisions of Nomenclature of Certain North American Birds,' in Bull. U. S. Nat. Mus., 1880, pp. 1-16.

168. Cooper on the Migration and Nesting Habits of West-Coast Birds. <Bull. Nutt. Ornith. Club, V, p. 232, Oct., 1880.

Review of Dr. J. G. Cooper's paper of this title in Proc. U. S. Nat. Mus., 1879, pp. 241251.

169. Langdon's Ornithological Field Notes. <Bull. Nutt. Ornith. Club, V, pp. 232233, Oct., 1880.

Review of Frank W. Langdon's paper in Journ. Cincinnati Soc. Nat. Hist., July, 1880, pp. 121-127.

170. Stearns's List of the Birds of Fishkill, New York. <Bull. Nutt. Ornith. Club, V, p. 233, Oct., 1880 .

Review of a privately printed brochure ( $8 \mathrm{vo}$, pp. 16, without date).

171. Harvie-Brown on the Effects of an unusually severe Winter upon Scottish Birds. <Bull. Nutt. Ornith. Club, V, pp. 233-234, Oct., 1880. 190.

Review of a paper by J. A. Harvie-Brown, in Proc. Nat. Hist. Soc. Glasgow, 1879, pp. 123-

172. Frank R. Rathbun's 'Bright Feathers.' <Bull. Nutt. Ornith. Club, V, p. 234, Oct., 1880.

Review of Part I of this work (4to, Auburn, N. Y.).

173. C. B. Cory's 'Beautiful and Curious Birds of the World.' < Bull. Nutt. Ornith. Club, p. 236, Oct., 1880.

Review of Part I, of this work (elephant-folio, Boston, 1880).

1881.

174. New England Bird Life. <The Nation, No. 845, Sept. 8, 1881. (Anonymous.) Review of Part I of Winifrid A. Stearns and Elliott Coues's 'New England Bird-Life' (8vo, Boston, 1881). 
175. Insectivorous Birds in their Relation to Man.<Bull. Nutt. Ornith. Club, VI, pp. 22-27, Jan., 1881.

Summary of recent investigations in economic ornithology.

176. Coues's Third Instalment of American Ornithological Bibliography. $<$ Bull. Nutt. Ornith. Club, VI, pp. 44-46, Jan., 1881.

Review of the Systematic Section, in Bull. U. S. Geol. and Geogr. Surv. Terr., V, 1880, pp. 521-1066.

177. Coues's Fourth Instalment of Ornithological Bibliography. $<$ Bull. Nutt. Ornith. Club, VI, p. 46, Jan., 1881.

Review of the section relating to British Birds, in Proc. U. S. Nat. Mus., II, 1880, pp. 359-476.

178. Minor Ornithological Papers. <Bull. Nutt. Ornith. Club, VI, pp. 47-53, Jan., 1881.

Includes 86 titles (Nos. 55-140). Cf. supra, No. 154.

179. Some Observations on the Migration of Birds. $<$ Bull. Nutt. Ornith. Club, VI, pp. 100, 188, April, 1881.

A half-page footnote to W. E. D. Scott's paper of this title, and a later correction of an erroneous statement in it. Mr. Scott's paper relates to observations made at night through a telescope at Princeton, N. J.

180. Shufeldt's Osteological Memoirs. <Bull. Nutt. Ornith. Club, VI, pp. 109-110, April, 1881.

Reviews of Dr. R. W. Shufeldt's papers on the Burrowing Owl and Horned Lark, in Bull. U. S. Geol. and Geogr. Surv. Terr., VI, 1881.

181. Minor Ornithological Papers.<Bull. Nutt. Ornith. Club, VI, pp. 112-113, April, 1881.

Titles Nos. 141-160. (Cf. supra, Nos. 154 and 178.)

182. Supplementary List of Birds of the Island of Santa Lucia, W. I. $<$ Bull. Nutt. Ornith. Club, VI, p. 128, April, 1881.

Adds 12 species to the previously published List (cf. supra, No. 148).

183. Winter Birds of Fort Walla Walla, W. T. $<$ Bull. Nutt. Ornith. Club, VI, p. 128, April, 1881.

Based on letters from Capt. Charles Bendire.

184. Ridgway's Nomenclature of North American Birds. <Bull. Nutt. Ornith. Club, VI, pp. 164-171, July, 1881.

Review, with historical summary of the subject, of R. Ridgway's paper under this title (Bull. U. S. Nat. Mus., No. 21, 1881).

185. Ridgway's Revised Catalogue of the Birds of Illinois. $<$ Bull. Nutt. Ornith. Club, VI, pp. 171-172, July, 1881.

Review of R. Ridgway's paper in Bull No. 4, Illinois State Lab. Nat. Hist., 1881.

186. Godman and Salvin's 'Biologia Centrali-Americana.' <Bull. Nutt. Ornith. Club, VI, pp. 174-176, July, 1881.

Review of the 'Aves' (Zoölogy, Parts I-X, p. 1-152, pll. i-x). 
187. A Second Massachusetts Specimen of the Red-bellied Woodpecker (Centurus carolinus). <Bull. Nutt. Ornith. Club, VI, p. 183, July, 1881.

188. Larus glaucus in Texas. <Bull. Nutt. Ornith. Club, VI, No. 3, p. 187, July, 1881. Record of a specimen taken in Clay County, Texas, Dec. 18, 1880.

189. The Migration of Birds. <Scribner's Monthly Magazine, XXII, pp. 932-938, Oct., 1881.

A general review of the subject from the viewpoint of the author, elaborating points stated in No. 147, supra.

1882.

190. Capture of Plectrophenax nivalis in Chester, South Carolina. <Bull. Nutt. Ornith. Club, VII, p. 54, Jan., 1882.

Given on authority of Leverett M. Loomis.

191. The Sharp-tailed Finch [Ammodramus caudacutus nelsoni] in Kansas. <Bull. Nutt. Ornith. Club, VII, p. 55, Jan., 1882.

192. Minor Ornithological Papers.<Bull. Nutt. Ornith. Club, VII, pp. 115-118, April, 1882.

Titles numbered 161-189. (Cf supra, Nos. 154, 178, and 181.)

1883.

193. [Note on a Hybrid Sparrow (Zonotrichia albicollis + Junco hyemalis).] $<$ Bull. Nutt. Ornith. Club, VIII, pp. 79-80, April, 1883. Description (l. c.) by Mr. Charles H. Townsend.

194. Note on Exceptions to the Law of Increase in Size Northward among North American Birds. < Bull. Nutt. Ornith. Club, VIII, pp. 80-82, April, 1883.

In certain genera of Oscines which are for the most part tropical in distribution.

195. The British Museum Catalogue of Birds. <Bull. Nutt. Ornith. Club, VIII, pp. 99-105, April, 1883.

Review of Vols. IV, V, VI.

196. Ridgway on the Tree-creepers. <Bull. Nutt. Ornith. Club, VIII, p. 113, April, 1883.

Review of R. Ridgway's paper on the group (in Proc. U. S. Nat. Mus., 1882, pp. 111-116).

197. Ridgway's Review of the Genus Centurus. $<$ Bull. Nutt. Ornith. Club, VIII, p. 114, April, 1883.

Notice of the paper (in Proc. U. S. Nat. Mus., 1881, pp. 93-119).

198. Freke on North American Birds crossing the Atlantic. <Bull. Nutt. Ornith. Club, VIII, pp. 114-115, April, 1883.

Review of Percy Evans Freke's paper of this title, published in Sci. Proc. Dublin Soc., III, 1881.

199. Freke on European Birds Observed in America. <Bull. Nutt. Ornith. Club, VIII, p. 115, April, 1883.

Review of Percy Evans Freke's paper of this title in The Zoologist, Sept., 1881. 
200. Minor Ornithological Publications. <Bull. Nutt. Ornith. Club, VIII, pp. 116119, April, 1883.

Continued, embracing titles numbered 190-235. (Cf. supra, Nos. 154, 178, 181, and 192.)

201. Capture of the Great Gray Owl in Massachusetts. <Bull. Nutt. Ornith. Club, VIII, p. 123, April, 1883.

Near Springfield, Feb., 1882.

202. List of Birds Observed in the Vicinity of Colorado Springs, Colorado, during March, April and May, 1882. <Bull. Nutt. Ornith. Club, VIII, pp. 151-161, 189-198, 1883.

With William Brewster. An Annotated list of 134 species.

203. Ridgway on New Species and Subspecies of Birds. <Bull. Nutt. Ornith. Club, VIII, pp. 168-169, July, 1883.

Brief notices of eight of R. Ridgway's recent papers.

204. Dubois on Geographical Variation in the Crossbills. $<$ Bull. Nutt. Ornith. Club, VIII, p. 170, July, 1883.

Review of "De la Variabilité des Oiseaux du genre Loxia" (Bull. du Musée royal d'Hist. Nat. de Belgique, I, 1882).

205. Minor Ornithological Publications. <Bull. Nutt. Ornith. Club, VIII, pp. 171178, July, 1883. 200.)

Continued, including titles numbered 236-364. (Cf. supra, Nos. 154, 178, 181, 192, and

206. The Wood Ibis in Massachusetts. <Bull. Nutt. Ornith. Club, VIII, p. 187, July, 1883.

Taken at Georgetown, Mass., June 19, 1880.

207. The American Ornithologists' Union. <Bull. Nutt. Ornith. Club, VIII, pp. 221226, Oct., 1883.

Its origin and founding, etc.

208. Goss's Birds of Kansas. <Bull. Nutt. Ornith. Club, VIII, p. 227, Oct., 1883.

Review of 'A Catalogue of the Birds of Kansas' by N. S. Goss (8vo, Topeka, 1883).

209. Beckham's Birds of Nelson County, Kentucky.<Bull. Nutt. Ornith. Club, VIII, pp. 227-228, Oct., 1883.

Review of C. W. Beckham's paper in Journ. Cincinnati Soc. Nat. Hist., VI, pp. 136-147, July, 1883 .

210. Migration of Birds. <Bull. Nutt. Ornith. Club, VIII, pp. 228-231, Oct., 1883. Notices of seven Migration Reports, of different countries, for the years 1880 and 1881 .

211. Bean's Notes on Birds Collected in Alaska and Siberia. <Bull. Nutt. Ornith. Club, p. 231, Oct., 1883.

Review of Tarleton H. Bean's paper (Proc. U. S. Nat. Mus., V, 1882, pp. 144-173).']

212. Turner on Lagopus mutus and its Varieties. <Bull. Nutt. Ornith. Club, VIII, p. 232, Oct., 1883.

Review of Lucien M. Turner's paper (Proc. U. S. Nat. Mus., V, 1882, pp. 225-233). 
213. Reichenow's 'Die Vögel der Zoologischen Gärten.' <Bull. Nutt. Ornith. Club, VIII, p. 232, Oct., 1883.

Review of Part 1, of this work (8vo, Leipzig, 1882).

214. Minor Ornithological Publications. <Bull. Nutt. Ornith. Club, VIII, pp. 223238, Oct., 1883. 205.)

Continued, including titles numbered 365-454. (Cf. supra, Nos. 154, 178, 181, 200, and

215. Intelligence of the Crow.<Science, N. S., I, No. 18, p. 513, June 8, 1883.

216. New England Bird Life.<The Nation, No. 939, p. 537, June 21, 1883. [Anon.]

Review of Part II of Stearns and Coues's 'New England Bird Life.'

1884

217. Stejneger and Ridgway on Birds of the Commander Islands. $<A u k$, I, pp. 8182, Jan., 1884.

Review of 'Contributions to the Natural History of the Commander Islands, No. 1' (Proc. U.S. Nat. Mus., 1883, pp. 58-89).

218. 1884-87. Minor Ornithological Publications. $<A u k$, I, 1884, pp. 85-89, 185-190, 285-289; II, 1885, pp. 96-101, 209-214, 295-302; 372-375; III, 1886, pp. 270-273, 475-478; IV, 1887, pp. 66-69, 337-342.

An annotated list of 1199 titles of minor papers relating to ornithology, begun in 1880 in Bulletin Nuttall Ornithological Club, and closed with the last date here given. (Continued in later volumes of The Auk till 1894, by Charles F. Batchelder).

219. Coues's 'Key to North American Birds.' <Science, N. S., IV, pp. 86-87, July 25, 1884.

Review of the second edition.

220. Stejneger on the American Turdidæ. $<A u k$, I, pp. 181-182, April, 1884.

Review of Dr. L. Stejneger's 'Remarks on the Systematic Arrangement of the American Turdidæ' (Proc. U. S. Nat. Mus., V, 1882, pp. 449-483).

221. Jeffries on the Epidermal System of Birds. <Auk, I, pp. 182-183, April, 1884.

Review of J. Amory Jeffries's 'The Epidermal System of Birds' (Proc. Boston Soc. Nat. Hist., XXII, pp. 203-240, pll. iv-vi, Dec. 1883).

222. A Plea for the Metric System in Ornithology. <Auk, I, April, 1884, pp. 203-205. 'Plea.'

Communication by Dr. C. Hart Merriam, with editorial comment in approval of the

223. The British Museum Catalogue of Birds. <Auk, I, pp. 278-281, July, 1884.

Review of Vol. VII, by R. Bowdler Sharpe, and Vol. VIII, by Hans Gadow.

224. Coues's 'Key to North American Birds.' <Auk, I, pp. 282-283, July, 1884.

Review of second edition.

224. Key to North American Birds. <The Nation, XXXIX, No. 996, p. 99, July 31, 1888. (Anon.)

Review of second edition of Coues's work of this title. 
226. Second Meeting of the American Ornithologists' Union. $<A u k$, I, pp. 369379 , Oct., 1884.

227. Brewster on Birds in the Gulf of St. Lawrence. $<A u k$, I, pp. 379-380, Oct., 1884 .

Review of William Brewster's 'Notes on the Birds of a Summer Cruise in the Gulf of St. Lawrence' (Proc. Boston Soc. Nat. Hist., XXII, pp. 364-412).

228. Baird, Brewer, and Ridgway's 'Water Birds of North America.' $<A u k, \mathrm{I}$, pp. 382-386, Oct., 1884.

Review of the work (2 vols., 4 to, Boston, 1884).

1885.

229. A Naturalist's Rambles about Home. <Auk, II, pp. 86-88, June, 1885.

Review of Chas. C. Abbott's book of this title (8vo, New York, 1884).

230. Seebohm's History of British Birds. <Auk, II, pp. 88-91, Jan., 1885.

Review of the work entitled "A History of British Birds, with colored illustrations of their Eggs' (2 vols., roy. 8vo, London, 1883).

231. Where Robin goes in Winter.<Every Other Sunday, p. 6, May, 1885.

232. Birds in the Bush. <The Nation, XLI, No. 1045, p. 39, July 9, 1885. (Anon.)

Review of Bradford Torrey's 'Birds in the Bush.'

233. Ridgway on New Species and Subspecies of American Birds, and on the Nomenclature of other Species. <Auk, II, pp. 290-293, July, 1885.

Brief notices of 19 papers by R. Ridgway in Proc. U. S. Nat. Mus., Vols. VI, VII, VIII, 1883-1885.

234. Capture of Escaped Cage-birds. <Auk, II, p. 314, July, 1885.

An Australian Parakeet in California and a Java Sparrow in Massachusetts, with comment on the capture of wild exotic and even tropical cage-birds far from their natural environment.

235. [Annotations to] 'Early Spring Notes from the Mountains of Southern Arizona,' by W. E. D. Scott. <Auk, II, pp. 348-356, Oct., 1885.

Technical notes on Turdus unalascæ auduboni (p. 349), Certhia familiaris mexicana (p. 350), Catherpes mexicanus conspersus (p. 350), Troglodytes aëdon marianæ (p. 351), Junco cinereus palliatus (p. 354).

236. Sharpe's Catalogue of the Birds in the British Museum. $<A u k$, II, pp. 365368, Oct., 1885.

Review of Vol. X (Fringilliformes, Part I), with critical comment on questions of nomenclature.

237. Turner's List of the Birds of Labrador. <Auk, II, pp. 368-369, Oct., 1885. See also $A u k$, III, p. 141.

Review of L. M. Turner's paper (Proc. U. S. Nat. Mus., VIII, 1885, pp. 233-254).

238. Ridgway on New American Birds. <Auk, II, p. 370, Oct., 1885.

Review of five papers by R. Ridgway. 
239. Ridgway's List of Emended Names of North American Birds. <Auk, II, pp. 371-372, Oct., 1885.

Comment on R. Ridgway's 'Some Emended Names of North American Birds' (Proc. U. S. Nat. Mus., VIII, pp. 354, 355, Sept. 2, 1885).

240. A Hawk Owl (Surnia ulula caparoch) at Chatham, Mass. $<A u k$, II, p. 383, Oct., 1885.

241. A Crested Auk on the Massachusetts Coast. <Auk, II, p. 388, Oct., 1885.

Apparently Simorhynchus cristatellus.

1886.

242. Third Meeting of the American Ornithologists' Union. $<A u k$, III, pp. 115122, Jan., 1886.

243. Murdoch on the Birds of Point Barrow, Alaska. <Auk, III, pp. 122-124, Jan., 1886.

Review of John Murdoch's Point Barrow Natural History Report.

244. Bird Protection by the A. O. U. <Forest and Stream, XXV, No. 26, Jan. 21, 1886. (Anon.)

Formation of a Committee on Bird Protection, etc.

245. Stejneger's Ornithological Explorations in Kamtschatka. <Auk, III, pp. 126129, Jan., 1886.

Review of Stejneger's 'Results of Ornithological Explorations in the Commander Islands and Kamtschatka.' 8vo, 1895 (= Bull. No. 29, U. S. Nat. Mus.).

246. [John Burroughs on Ornithologists as Bird Enemies.] <Auk, III, p. 142, Jan., 1886.

Comment on his article in The Century in which ornithologists are classified as "among the worst enemies" of birds.

247. On the Avi-fauna of Pinal County, with Remarks on Some Birds of Pima and Gila Counties, Arizona. By W. E. D. Scott. With Annotations by J. A. Allen. <Auk, III, 1886, pp. 249-258, 383-389, 421-432; IV, 1887, pp. 16-24, 196-205; V, 1888, pp. 29-36, 159-168.

The annotations relate to the following species: Rallus virginianus, Vol. III, p. 385 ; Porzana carolina, p. 386; Colinus ridgwayi, p. 387; Callipepla squamata, p. 388; Geococcyx californianus, p. 425; Dryobates stricklandi, p. 426; Melanerpes torquatus, p. 428; Iache latirostris, p. 432; Myiarchus cinerascens, Vol. IV, p. 18; Aphelocoma sieberi arizonæ, p. 21; Icterus parisorum, p. 23 ; I. cucullatus nelsoni, p. 23; Carpodacus purpureus californicus, p. 196; Loxia curvirostris stricklandi, p. 197; Spinus tristis, p. 198; S. pinus, p. 199; Spizella socialis arizonæ, p. 200; Junco hyemalis, oregonus, annectens, caniceps, dorsalis, palliatus, pp. 201-202; Amphispiza bilineata, p. 202; Peucæa ruficeps boucardi, p. 203; Pipilo fuscus mesoleucus, p. 204; Vireo gilvus swainsoni, p. 32; Vireo solitarius plumbeus and V. s. cassinii, p. 32 ; Dendroica æstiva morcomi, p. 34; Mimus polyglottus, p. 160; Catherpes mexicanus conspersus, p. 162; Troglodytes aëdon group, pp. 163-165; Turdus aonalashkæ auduboni, p. 167.

248. The Present Wholesale Destruction of Bird-Life in the United States. <Science, VII, No. 160, pp. 191-195, Feb. 26, 1886. Also, Bulletin No. 1, of the A. O. U. Committee on Protection of Birds, pp. 1-5, March, 1886. 
249. Destruction of Birds for Millinery Purposes. <Science, VII, No. 160, pp. 196197, Feb. 26, 1886. Also, Bull. No. 1, A. O. U. Committee on Protection of Birds, pp. 6-7, March, 1886. (Anon.)

250. The Relation of Birds to Agriculture. <Science, VII, No. 160, pp. 201-202, Feb. 26, 1886. Also, Bull. No. 1, A. O. U. Committee on Protection of Birds, pp. 11-12, March, 1886. (Anon.)

251. Bird-Laws.<Science, Vol. VII, No. 160, pp. 202-204, Feb. 26, 1886. Also, Bull. No. 1, A. O. U. Committee on Protection of Birds, pp. 12-14. (Anon.)

252. An Appeal to the Women of the Country in Behalf of the Birds. <Science, VII, No. 160, pp. 204-205, Feb. 26, 1886 . Also, Bull. No. 1, A. O. U. Committee on Protection of Birds, pp. 14-15. March, 1886.

253. Protection of Birds by Legislation. <Forest and Stream, XXVII, No. 16, pp. 304-305, Nov. 11, 1886. Also, Bull. No. 2, of the A. O. U. Committee on Protection of Birds, pp. 1-7, Nov., 1886.

Signed by the Committee, but written by J. A. A., and published with articles by other contributors.

254. Capture of a Pair of Wild Hybrid Ducks (Mallard + Muscovy) on Long Island. $<A u k$, III, pp. 274-275, April, 1886.

255. The Masked Bob-White (Colinus ridgwayi) in Arizona. <Auk, III, pp. 275276, April, 1886.

256. [Note on an Abnormally Colored Bluebird (Sialia sialis).]<Auk, III, p. 282, footnote, April, 1886.

257. The A. O. U. Check-List of North American Birds. <Auk, III, pp. 397-398, July, 1886.

Review of the first edition. Descriptive account, following a critical review of the 'Code and Check-List' by David Starr Jordan.

258. Note on Two Specimens of the Snowy Plover from the Indian Territory. $<A u k$, III, p. 409, July, 1886.

259. 'Aptoso-Chromatism.' <Auk, III, pp. 413-414, July, 1886.

Criticism of Mr. Hoxie's theory respecting " a 'moultless color change' in the feathers of birds," designated 'Aptoso-Chromatism.'

260. 'The Standard Natural History' - 'Birds.'<Auk, III, pp. 473-474, Oct., 1886.

Review of Vol. IV of this work (imp. 8vo, Boston, 1885).

261. Égialitis meloda circumcincta on the Atlantic Coast.<Auk, III, pp. 482-483, Oct., 1886.

In New Jersey and Maine.

262. A Revised List of the Birds of Massachusetts. <Bull. Amer. Mus. Nat. Hist., I, No. 7, pp. 221-271, July, 1886.

An annotated list of 340 species, plus 4 species extirpated, 4 introduced, and 19 of probable occurrence. The third and last list of the birds of Massachusetts published by this author. 
263. The Masked Bob-White (Colinus ridgwayi) of Arizona, and its Allies. $<$ Bull. Amer. Mus. Nat. Hist., I, No. 7, pp. 273-290, with col. pl., July, 1886.

264. The Type Specimen of Colinus ridgwayi. <Auk, III, p. 483, Oct., 1886.

Stated to be in the collection of G. Frean Morcom, of Chicago.

265. Three Interesting Birds in the American Museum of Natural History: Ammodramus leconteii, Helinaia swainsoni, and Saxicola ænanthe. $<A u k$, III, pp. 489-490, Oct., 1886.

The Leconte's Sparrow was taken by Prince Maximilian in 1832-34, some ten years before the discovery of the species by Audubon.

266. Bird Destruction. <Science, VIII, No. 183, pp. 118-119, Aug. 6, 1886.

\section{7.}

267. Stejneger on Japanese Woodpeckers. <Auk, IV, pp. 63-64, Jan., 1887.

Notice of Dr. L. Stejneger's 'Review of Japanese Birds, I. The Woodpeckers' (Proc. U. S. Nat. Mus., 1886, pp. 200-201).

268. Ferrari-Perez on the Birds of Mexico. $<A u k$, IV, p. 65, Jan., 1887.

Notice of Fernando Ferrari-Perez's 'Catalogue of Animals collected by the Geogr. and Expl. Comm. of the Republic of Mexico,' in Proc. U. S. Nat. Mus., 1886, pp. 125-199 (birds, pp. 130-182).

269. Fourth Meeting of the American Ornithologists' Union. <Auk, IV, pp. 56-61, Jan., 1887.

270. A Further Note on Colinus ridgwayi. $<A u k$, IV, pp. 74-75, Jan., 1887.

Additional specimens noted, including two early examples in Mr. Henshaw's collection.

271. [Note on Florida Specimens of Dendroica discolor.] $<A u k$, IV, p. 135, footnote, April, 1887.

272. Sclater's Catalogue of the Cœrebidæ, Tanagridæ, and Icteridæ. $<A u k$, IV, pp. 149-150, April, 1887.

Review of Vol. XI of the British Museum Catalogue of Birds.

273. Ridgway's Nomenclature of Colors and Ornithologists' Compendium. $<A u k$, IV, pp. 151-152, April, 1887.

Review of R. Ridgway's work entitled 'A Nomenclature of Colors for Naturalists, and Compendium of Useful Knowledge for Ornithologists' (8vo, Boston, 1886).

274. [The Redpolls of Massachusetts.]<Auk, IV, p. 164, April, 1887.

A note of explanation, in reply to a communication by Mr. W. Brewster.

275. [The Antedating of Papers and Works on Natural History.] $<A u k$, IV, p. 176, April, 1887. See also op. cit., p. 270.

276. [Additions in the Department of Ornithology at the American Museum of Natural History.] <Auk, IV, pp. 270-272, July, 1887.

They include the D. G. Elliot collection of Hummingbirds, the George N. Lawrence collection (with the types of about 300 species of American birds), and the H. H. Smith collection of birds from Chapada, Matto Grosso, Brazil; also an account of the beginning of 
the Museum's series of Bird Groups, which later came to form so striking a feature of the Museum's exhibition series of birds. The acquisition of the Elliot ornithological library is also noted.

277. The Pine Finch (Spinus pinus) Breeding at Cornwall-on-Hudson, N. Y. $<A u k$, IV, pp. 284-286, July, 1887.

The parent birds, with the nest and eggs, were used for a 'habitat group' in the American Museum of Natural History, where it is still (1916) on exhibition.

278. Ridgway's Manual of North American Birds. <Auk, IV, pp. 333-336, Oct., 1887.

Review of R. Ridgway's work of this title (roy. 8vo, Philadelphia, 1887).

279. Key to North American Birds. <The New York Evening Post, Dec. 21, 1887. Review of Dr. Coues's 'Key,' not signed.

280. What is a Bird? <Audubon Magazine, I, pp. 31-33, March, 1887.

1888.

281. Fifth Meeting of the American Ornithologists' Union. $<A u k$, V, pp. 95-100, Jan., 1888.

282. Coues's 'Key to North American Birds.' <Auk, V, pp. 101-104, Jan., 1888. Review of the third edition of E. Coues's work of this title (roy. 8vo, Boston, 1887).

283. [A Monument to Audubon.]<Auk, V, pp. 123-124, Jan., 1888. bon.

Account of the movement to erect a monument in New York City to John James Audu-

284. [The Bird Collection at the British Museum.]<Auk, V, pp. 124-125, Jan., 1888.

Summary of an article by R.!B. Sharpe on 'Ornithology at South Kensington.'

285. [A 'Discovery' in the Mechanism of Birds' Wings.] $<A u k, \mathrm{~V}, \mathrm{pp} .125-126$, Jan., 1888. See also op. cit. p. 223.

Account of a discussion in the New York Academy of Sciences on an alleged "important discovery," etc. Cf. infra, No. 303 .

286. Notes on the Summer Birds of Holderness, Bethlehem, and Franconia, N. H. (With Walter Faxon).<Auk, V, pp. 149-155, April, 1888.

Contains 'Notes on Birds Observed at Franconia and Bethlehem, in July and August, 1874,' by J. A. A., pp. 153-155, following two briefly annotated lists of birds of the same general region by Walter Faxon.

287. [On the Wrens of the Troglodytes adon Group.]<Auk, V, pp. 163-165, April, 1888. (Cf. supra, No. 247.)

288. Seebohm's 'Geographical Distribution of the Charadriidæ.' $<A u k$, V, pp. 189194, April, 1888.

Critical review of Henry Seebohm's work of this title (4to, London, 1888).

289. Ridgway on New or Little-known American Birds, etc. $<A u k, \mathrm{~V}$, pp. 194-195, April, 1888.

Brief notices of a number of R. Ridgway's papers. 
290. Stejneger on Japanese Birds, etc. <Auk, V, pp. 195-197, April, 1888.

Reviews of several of L. Stejneger's recent papers on Japanese birds.

291. Chamberlain's 'Systematic Table of Canadian Birds.' < Auk, V, pp. 198-199, April, 1888.

Review of Montague Chamberlain's work of this title (folio, St. John, N. B., 1888, pp. 14).

292. Sclater and Hudson's 'Argentine Ornithology.' <Auk, V, pp. 199-200, April, 1888.

Review of Vol. I of this well-known work (8vo, London, 1888).

293. Descriptions of two New Subspecies of the Seaside Sparrow (Ammodramus maritimus). <Auk, V, pp. 284-287, July, 1888.

Ammodramus maritimus peninsulæ, p. 284; A. m. sennetti, p. 286.

294. Description of a New Species of the Genus Tityra, from Ecuador. $<A u k, \mathrm{~V}$, pp. 287-288, July, 1888.

Tityra nigriceps, p. 287.

295. Notes on Louisiana Birds. <Auk, V, pp. 324-325, July, 1888.

Brief notes on several species.

296. [Bird Destruction for Millinery Purposes.]<Auk, V, pp. 334-335, July, 1888.

Some statistics of the London sales of bird skins for this use.

297. Turner's Report of his Ornithological Observations in Alaska. $<A u k, \mathrm{~V}, \mathrm{pp}$. 409-410, Oct., 1888.

Review of L. M. Turner's observations in Alaska in a 4 to report (No. 11) of the U.S. Signal Service (Birds, pp. 115-196, with 10 col. plls.).

298. Sharpe's Catalogue of the Fringillidæ. $<A u k$, V, pp. 410-413, Oct., 1888.

Review of Vol. XII of the British Museum Catalogue of Birds.

299. Shufeldt on the Osteology of the Icteridæ and Corvidæ. $<A u k, \mathrm{~V}, \mathrm{pp} .413-$ 414, Oct., 1888.

Review of a paper by R. W. Shufeldt (Journ. Anat. and Phys., XXII, pp. 309-350).

300. Note on the Correct Name of Symphemia semipalmata inornata Brewster. $<$ $<A u k$, V, pp. 423-424, Oct., 1888.

Claimed to be Symphemia semipalmata speculifera (Cuv.).

301. Visitor's Guide to the Collection of Birds in the American Museum of Natural History, Seventy-seventh Street and Eighth Avenue, New York City.J. A. Allen, Curator. New York: Printed for the Museum, 1888.-8vo, pp. 62 , + 3ll. unpaged, and 18 cuts in text.

302. List of Important Publications relating to Birds. <Riverside Natural History, Vol. IV, pp. 549-556, 1888.

188 titles.

1889.

303. On the Structure of Birds in Relation to Flight, with Special Reference to Recent Alleged Discoveries in the Mechanism of the Wing. < Trans. New York Acad. Sci., pp. 89-100, 1888. 
304. Sixth Congress of the American Ornithologists' Union. $<A u k$, VI, pp. $55-58$, Jan., 1889.

305. Cooke's 'Report on Bird Migration in the Mississippi Valley,' <Auk, VI, pp. 58-61, Jan., 1889.

Synoptic review of the work (U. S. Dept. Agric., Divis. of Economic Orn., Bull. No. 2).

306. Nelson's Report upon Natural History Collections made in Alaska. < Auk, VI, pp. 61-63, Jan., 1889.

Review of E. W. Nelson's 'Report' (4to, Washington, 1887-1888). Birds, pp. 19-230, with 12 col. plls.

307. Supplement to the A. O. U. Code of Nomenclature and Check-List of North American Birds and The Abridged A. O. U. Check-List. <Auk, VI, pp. 168169, April, 1889.

Notice of the first Check-List supplement.

308. Ridgway on New or Little-known American Birds. <Auk, VI, pp. 171-173, April, 1889.

Review of eight papers by R. Ridgway.

309. Beckham on the Birds of Southwestern Texas. $<A u k$, VI, pp. 173-174, April, 1889.

Review of C. W. Beckham's 'Observations on the Birds of Southwestern Texas (Proc. U. S. Nat. Mus., 1887, pp. 633-696.)

310. Note on the First Plumage of Colinus ridgwayi. <Auk, VI, p. 189, April, 1889.

311. Sclater's Catalogue of the Mesomyodian Passeres. < Auk, VI, pp. 266-268, July, 1889.

Review of Vol. XIV of the British Museum Catalogue of Birds.

312. Sclater and Hudson's Argentine Ornithology. <Auk, VI, pp. 268-269, July, 1889.

Review of Vol. II (London, 1889; for Vol. I cf. supra, No. 292). Also includes corrections of Barrows's 'Birds of the Lower Uruguay' (in Auk, I, 1884).

313. On Cyclorhis viridis (Vieill.) and its near Allies, with Remarks on other Species of the Genus Cyclorhis. <Bull. Amer. Mus Nat. Hist., II, pp. 123-135, June $17,1889$.

Cyclorhis flavipec/us trinitatis, subsp. nov., p. 131.

314. Descriptions of New Species of South American Birds, with Remarks on various other little-known Species. <Bull. Amer. Mus. Nat. Hist., II, pp. 137151, June 28, 1889.

Spp. nov.: (1) Thryothorus macrurus, p. 137; (2) Thryothorus longipes, p. 138; (3) Platyrhynchus bifasciatus, p. 141; (4) Platyrhynchus insularis, p. 143; (5) Sublegatus virescens, p. 149; (6) Empidonax lawrencei (=Octhoëca flaviventris Lawr.), p. 150; (7) Thamnophilus doliatus mexicanus, p. 151.

315. [Note on] the Breeding of the Florida Gallinule in Vermont. <Auk, VI, p. 274, July, 1889.

Follows a communication on this subject by Jenness Richardson. 
316. Report of the U. S. Ornithologist and Mammalogist for the Year 1888. $<A u k$, VI, p. 284, July, 1889.

Brief summary of report by C. Hart Merriam.

317. Barrows's Report on the English Sparrow in North America. <Auk, VI, pp. 326-328, Oct., 1889.

Review of W. B. Barrows's report on this subject, forming Bulletin I of the Division of Economic Ornithology and Mammalogy, U. S. Dept. Agric.

318. Gould's Ornithological Works. New York Evening Post, July 27, 1889. [Anonymous.]

Summary account of John Gould's principal ornithological works, with a brief biographical sketch of the author.

318a. Stone's Catalogue of the Muscicapidæ in the Collection of the Philadelphia Academy of Natural Sciences. <Auk, VI, pp. 330-331, Oct., 1889.

Review of Witmer Stone's paper of this title (Proc. Acad. Nat. Sci. Philadelphia, 1889, pp. 146-154),

319. Bergtold's List of the Birds of Buffalo and Vicinity. $<A u k$, VI, pp. 331-332, Oct., 1889.

Review of W. H. Bergtold's paper (in Bull. Buffalo Naturalists' Field Club, 1889).

320. Keyes and Williams's Preliminary Catalogue of the Birds of Iowa. <Auk, VI, p. 332 , Oct., 1889.

Review of their 'Catalogue' (in Proc. Davenport Acad. Nat. Sci., V, 1889).

321. Taylor's Catalogue of Nebraska Birds. <Auk, VI, pp. 332-333, Oct., 1889.

Review of W. Edgar Taylor's 'Catalogue' (in Ann. Rep. Nebraska State Board of Agric. for 1887, pp. 111-118, 1888).

322. Shufeldt's Recent Contributions to the Osteology of North American Birds. $<A u k$, VI, pp. 333-334, Oct., 1889.

Review of four papers by Dr. R. W. Shuf eldt on different groups of birds.

323. Notes on a Collection of Birds from Quito.<Bull. Amer. Mus. Nat. Hist., II, pp. 69-76, March 22, 1889.

An annotated list of 79 species. Manacus Brisson antedates Chiromachæris Cabanis (p. 73).

324. List of Birds Collected in Bolivia by Dr. H. H. Rusby, with Field Notes by the Collector. <Bull. Amer. Mus. Nat. Hist., II, 77-112, March 22, 1889.

Annotated list of 267 species, the following new: (1) Empidonax bolivianus, p. 86; (2) Chiroxiphia pareola boliviana, p. 87; (3) Enicornis striata, p. 89; (4) Leptasthenura fuscescens, p. 90; (5) Leptasthenura fuliginiceps boliviana, p. 91; (6) Synallaxis griseiventris, p. 91; (7) Anabazenops immaculatus, p. 96; (8) Picolaptes obtectus, p. 94; (9) Myrmochanes (gen. nov.) hypoleucus, p. 95; (10) Conopophaga rusbyi, p. 96; (11) Phlogopsis notata, p. 97; (12) Scytalopus bolivianus, p. 96.

325. Remarks on Individual and Seasonal Variation in a large Series of Elainea from Chapada, Matto Grosso, Brazil, with a Revision of the Species of the restricted Genus Elainea.<Bull. Amer. Mus. Nat. Hist., II, pp. 183-208, Oct. 31, 1889.

Critical comment on various alleged species of the genus. 
326. On the Maximilian Types of South American Birds in the American Museum of Natural History. <Bull. Amer. Mus. Nat. Hist., II, pp. 209-276, Dec., 1889.

About 160 species formally considered and incidental comment on 10 others. See also infra, No. 352 .

1890.

327. To What Extent is it Profitable to Recognize Geographical Forms among North American Birds?<Auk, VII, pp. 1-9, Jan., 1890.

A protest against too fine splitting.

328. Seventh Congress of the American Ornithologists' Union. $<A u k$, VII, pp. 6671, Jan., 1890.

329. Waterhouse's 'Index Generum Avium.' <Auk, VII, pp. 71-73, Jan., 1890. 1889).

Review, with critical comment, of F. H. Waterhouse's work of this title (8vo, London,

330. Blanchard on the Nomenclature of Organized Beings. $<A u k$, VII, pp. 73-74, Jan., 1890.

Review of Blanchard's Report 'De la Nomenclature des êtres organisés,' presented to the Congrès International de Zoologie, Paris, 1889.

331. Menzbier's Ornithology of Turkestan. <Auk, VII, pp. 78-79, Jan., 1890.

Review of the first livraison of the work.

332. Note on Thryothorus ludovicianus miamensis. $<A u k$, VII, pp. 115-117, April, 1890.

Inedited matter in a paper by W. E. D. Scott on Birds of the Gulf Coast of Florida.

333. Saunders's Manual of British Birds. <Auk, VII, pp. 195-196, April, 1890. 1889).

Review of 'An Illustrated Manual of British Birds,' by Howard Saunders (8vo, London,

334. Notes on Sport and Ornithology. $<A u k$, VII, pp. 196-197, April, 1890. 1889).

Review of a work of this title by the late Crown Prince Rudolf of Austria (8vo, London,

335. Ridgway on the Genus Ziphocolaptes. $<A u k$, VII, pp. 271-272, July, 1890.

Notice of R. Ridgway's 'A Review of the' Genus Xiphocolaptes of Lesson' (Proc. U.S. Nat. Mus., 1889, pp. 1-20).

336. Ridgway on the Genus Sclerurus. <Auk, VII, pp. 272-273, July, 1890.

Notice of R. Ridgway's 'A Review of the Genus Sclerurus of Swainson' (Proc. U. S. Nat. Mus., 1889, pp. 21-31).

337. Ridgway on Birds from the Galapagos Islands, the Abrolhos, the Island of Santa Lucia, and the Straits of Magellan. <Auk, VII, pp. 273-274, July, 1890.

Notice of 'Scientific Results of Explorations by the U. S. Fish Commission Steamer Albatross. No. 1, Birds Collected on the Galapagos Islands in 1888,' and 'No. 2, Birds Collected on the Island of Santa Lucia,' etc. by R. Ridgway (Proc. U. S. Nat. Mus., 1889, pp. 101-139).

338. Chapman on the Genus Xiphorhynchus. <Auk, p. 274, July, 1890.

Notice of "A Review of the Genus Xiphorhynchus Swainson, with Descrip tions of two new Species,' by F. M. Chapman (Bull. Amer. Mus. Nat. Hist., II, pp. 153-162, July, 1889). 
339. Stejneger and Lucas on Pallas's Cormorant. <Auk, VII, pp. 276-277, July, 1890.

Review of 'Contributions to the Natural History of the Commander Islands, X.' By L. Stejneger and F. A. Lucas (Proc. U.S. Nat. Mus., XII, pp. 83-94, pll. ii-iv).

340. Lucas on the Osteology of the Thrushes and Wrens. <Auk, VII, p. 277, July, 1890.

Review of F. A. Lucas's 'Notes on the Osteology of the Thrushes, Miminæ, and Wrens' (Proc. U. S. Nat. Mus., 1888, pp. 173-180).

341. Shufeldt on the Relationships of the Genus Chamca. <Auk, VII, p. 278, July, 1890.

Review of R. W. Shufeldt's paper 'On the Position of Chamra in the System' (Journ. Morph., III, pp. 475-502).

342. Shufeldt's "Studies of the Macrochires." Auk, VII, pp. 278-279, July, 1890.

Review of his 'Studies,' etc., in Journ. Linn. Soc., Zool., XX, pp. 299-394, pll. xvii-xxiv.

343. Shufeldt on the Osteology of the North American Passeres. <Auk, VII, pp. 279-280, July, 1890.

Review of his 'Contributions to the Comparative Osteology of Families of the North American Passeres,' in Journ. Morph., III, 1889, pp. 81-112, pll. v, vi.

344. Maynard's 'Eggs of North American Birds.' <Auk, VII, p. 280, July, 1890.

Review of C. J. Maynard's work of this title (8vo, Boston, 1890).

345. Anthony on New Birds from Lower California. <Auk, VII, pp. 281-282, July, 1890.

Review of A. W. Anthony's paper of this title in Proc. California Acad. Sci., 2d Ser., II, 1889 , pp. $75-82$.

346. Sennett on Bird Legislation. <Auk, VII, p. 282, July, 1890.

Review of an address on the subject by G. B. Sennett, published in Rep. Board of Agric. Penn. for 1889.

347. Description of a New Species of Icterus from Andros Island, Bahamas. $<A u k$, VII, pp. 343-346, Oct., 1890; and ibid., VIII, 1891, pl. i (colored).

Icterus northropi sp. nov. Description and plate republished in 'A Naturalist in the Bahamas,' a memorial volume of the late John I. Northrop (8vo, New York, 1910).

348. Sclater's Catalogue of the Tracheophonæ. <Auk, VII, pp. 379-380, Oct., 1890.

Review of Vol. XV of the British Museum Catalogue of Birds.

349. Dr. Merriam's 'Biological Survey' of the United States. $<A u k$, VII, p. 414, Oct., 1890.

Inception of a 'Biological Survey' under Dr. C. Hart Merriam, and nature of the proposed work.

1891.

350. List of the Birds of Labrador, including Ungave, East Main, Moose, and Guld Districts of the Hudson Bay Company, together with the Island of Anticosti. By Lucien M. Turner. Reprinted by the author's permission from the Proceedings of the U. S. National Museum, 1885, pp. 233-254. Revised and brought down to date [1891], by J. A. Allen. < Packard's 'The Labrador Coast,' pp. 406-442, 1891. 
351. The American Ornithologists' Union. A Seven Years' Retrospect. An Address delivered by the Retiring President at the Eighth Congress of the Union, Nov. 19, 1890. By J. A. Allen. Published by order of the Union, New York, January, 1891.-8vo, pp. 19, and title page.

352. Further Notes on Maximilian Types of South American Birds. <Bull. Amer. Mus. Nat. Hist., III, pp. 199-202, Feb. 20, 1891. (Cf. supra, No. 326.) Rhopocichla, gen. nov., p. 199.

353. [Annotations to] 'The Birds of Andros Island, Bahamas.' By John I. Northrop. $<A u k$, VIII, pp. 64-80, Jan., 1891.

Notes on: Mimus polyglottos, p. 67; M. gundlachi, p. 67; Seiurus aurocapillus, p. 68; Geothlypis rostrata, p. 69; Vireo crassirostris, p. 70; Myiarchus lucaysiensis, p. 72; Speotyto cunicularia dominicensis, p. 75; Rallus coryi, p. 77.

354. Sharpe's 'Catalogue of the Sturniformes.' <Auk, VIII, pp. 90-92, Jan., 1891. Review of Vol. XIII of the British Museum Catalogue of Birds.

355. Hargitt's Catalogue of the Woodpeckers. <Auk, VIII, pp. 92-95, Jan., 1891. Review of Vol. XVIII of the British Museum Catalogue of Birds.

356. Merriam's 'Results of a Biological Survey of the San Francisco Mountain Region and Desert of the Little Colorado, Arizona.' Auk, VIII, pp. 95-98, Jan., 1891.

Review of C. Hart Merriam's 'Results,' etc., in North Am. Fauna, No. 3, Sept., 1891.

357. Dr. Merriam's Exploration of the Death Valley Region. $<A u k$, VIII, pp. 122-123, Jan., 1891.

Announcement of the Expedition.

358. Description of a New Species of Mimocichla, from the Island of Dominica, West Indies. <Auk, VIII, pp. 217-218, April, 1891.

Mimocichla verrillorum $=M$. ardesiaca albiventris Scl. of slightly earlier date (See Auk, VIII, 1891, p. 317.)

359. The Ornithology of the 'Century Dictionary.' $<A u k$, VIII, pp. 222-224, April, 1891.

Review of Dr. E. Coues's ornithological contributions to the 'Century Dictionary.'

360. Nicholson's Translation of Sundevall's 'Tentamen.' <Auk, VIII, pp. 227-228, April, 1891.

Review of the work (8vo, London, 1889).

361. Goss's 'History of the Birds of Kansas.' < Auk, VIII, pp. 228-230, April, 1891. Review of N.S. Goss's work of this title (roy. 8vo, Topeka, 1891).

362. Gätke's 'Die Vogelwarte Helgoland.' <Auk, VIII, pp. 299-300, July, 1891. Review of Heinrich Gätke's work of this title (roy. 8vo, Braunschweig, 1891).

363. Cory's 'Birds of the Bahama Islands.' <Auk, VIII, pp. 300-301, July, 1891. Review of the revised edition, 1890.

364. Grant's 'Our Common Birds [and how to know them].' <Auk, VIII, p. 301, July, 1891.

Review of John B. Grant's work of this title (New York, 1891). 
365. Thompson's 'Birds of Manitoba.' <Auk, VIII, pp. 301-302, July, 1889.

Review of E. E. Thompson's paper in Proc. U. S. Nat. Mus., XIII, 1890, pp. 457-643, pl. xxxviii.

366. Canadian Bird Notes. $<A u k$, VIII, pp. 302-303, July, 1891.

Review of ornithological papers in Trans. Canadian Inst., 1890.

367. Stone's List of 'Birds Collected in Yucatan and Southern Mexico' on the Heilprin Expedition. <Auk, VIII, p. 303, July, 1891.

Review of Witmer Stone's paper in Proc. Acad. Nat. Sci. Philadelphia, 1890, pp. 201-218.

368. Townsend on the Birds of the Coast and Islands of Upper and Lower California. <Auk, VIII, p. 305, July, 1891.

Review of Charles H. Townsend's 'Birds from the Coasts of Western North America and adjacent Islands' (Proc. U. S. Nat. Mus., XIII, 1890, pp. 131-142).

369. Palmer on Birds observed during the Cruise of the 'Grampus.' $<A u k$, VIII, p. 305, July, 1891.

Review of William Palmer's paper in Proc. U. S. Nat. Mus., XIII, 1890, pp. 249-262, on birds observed in Gulf of St. Lawrence, and at Funk Island, etc.

370. Lucas on the Anatomy and History of the Great Auk. $<A u k$, VIII, p. 306, July, 1891.

Review of F. A. Lucas's paper in Rep. U. S. Nat. Mus., 1887-88, pp. 493-529, pll. Ixxi-Ixxiii.

371. Capture of Geothlypis poliocephala palpebralis in Cameron County, Texas. $<$ $A u k$, VIII, p. 316, July, 1891.

372. Note on Mimocichla verrillorum. <Auk, VIII, p. 317, July, 1891.

Name antedated by Mimocichla albiventris (Scl.). See supra, No. 358.

373. [Plates of Otophanes mcleodii Brewster, and of two species of Megascops].< Auk, VIII, p. 320, Oct., 1891.

Explanatory note.

374. Sharpe's 'Review of Recent Attempts to Classify Birds.' <Auk, VIII, pp. 379381, Oct., 1891.

Notice of Dr. R. B. Sharpe's address on this subject before Second Int. Orn. Congress, Budapest, 1891.

375. Hornaday's Handbook of Taxidermy and Zoölogical Collecting. <Auk, VIII, pp. 381-383, Oct., 1891.

Review of Wm. T. Hornaday's work of this title (8vo, New York, 1891).

376. Butler's Birds of Indiana. <Auk, VIII, pp. 383-384, Oct., 1891.

Review of Amos W. Butler's 'Birds of Indiana' (8vo, pp. 135).

377. Colburn and Morris's 'Birds of the Connecticut Valley in Massachusetts.' < $A u k$, VIII, pp. 384-385, Oct., 1891.

Review of their privately printed brochure of this title (16mo, pp. 24 , Springfield, Mass.).

378. Merriam's List of Birds Observed in Idaho. <Auk, VIII, p. 385, Oct., 1891.

Review of list in N. Am. Fauna, No. 5. 
379. Maynard's 'Contributions to Science.' <Auk, VIII, pp. 385-387, Oct., 1891. Notice of 16 papers relating to ornithology contained in Vol. I of his work of this title.

380. On a Collection of Birds from Chapada, Matto Grosso, Brazil, made by Mr. Herbert H. Smith. Part I, Oscines. <Bull. Amer. Mus. Nat. Hist., III, pp. 337-380, Sept. 29, 1891.

87 species here treated: Callista margaritæ, sp. nov., p. 351; Zonotrichia capensis costaricensis, subsp. nov., p. 374 .

\section{2.}

381. The New Nuttall. <Auk, IX, pp. 59-61, Jan., 1892.

Review of Montague Chamberlain's 'A Popular Handbook of the Ornithology of the United States and Canada, based on Nuttall's Manual.' 2 vols., 8vo, Boston, 1891.

382. Shufeldt's 'Myology of the Raven.' <A uk, IX, p. 62, Jan., 1892.

Review of R. W. Shufeldt's work of this title (8vo, London and New York, 1890).

383. Bolles's 'Land of the Lingering Snow.' < Auk, IX, p. 62, Jan., 1892.

Review of Frank Bolles's work of this title (12mo, Boston and New York, 1891).

384. Keyser's 'Bird-dom.' < Auk, IX, p. 63, Jan., 1892.

Review of Leander Keyser's work thus entitled (12mo, Boston, 1891).

385. Packard's 'The Labrador Coast.' < Auk, IX, p. 171, April, 1892.

Review of A. S. Packard's work thus entitled (8vo, New York, 1891).

386. Lucas on the Osteology of the Paridæ, Sitta, and Chamoea. $<A u k$, IX, p. 172, April, 1892.

Review of a paper by F. A. Lucas entitled 'Notes on the Osteology of the Paridæ, Sitta, and Chamæa, in Proc. U.S. Nat. Mus., XIII, 1890, pp. 337-345, pl. xxvii.

387. G. K. Cherrie on Costa Rican Birds. <Auk, IX, p. 173, April, 1892.

Notice of his paper entitled 'Descriptions of New Genera, Species, and Subspecies of Birds from Costa Rica,' in Proc. U. S. Nat. Mus., XIV, 1892, pp. 337-346.

388. Shufeldt on the Osteology of Arctic and Sub-Arctic Water Birds. $<A u k$, IX, pp. 173-174, April, 1892.

Review of Parts V-IX, of R. W. Shufeldt's 'Contributions to the Comparative Osteology, etc., in Vols. XXIV and XXV, Journ. Anat. and Phys., 1890-91.

389. Shufeldt on the Osteology and Classification of the North American Pigeons, Woodpeckers, and Kites. <Auk, IX, p. 174, April, 1892.

Notice of four papers by R. W. Shufeldt.

390. Ridgway on New or Little-known Central American and South American Birds. <Auk, IX, pp. 174-175, April, 1892.

Short notices of nine papers by R. Ridgway in Proc. U. S. Nat. Mus., XIV, 1891.

391. Chapman on the 'Origin of the Avifauna of the Bahamas.' $<A u k$, IX, pp. 179180, April, 1892.

Review of F. M. Chapman's paper of this title in Amer. Nat., June, 1891, pp. 528-539.

392. Sclater on the Geographical Distribution of Birds. $<A u k$, IX, pp. 183-184, April, 1892. 
Review of an address on this subject read before the Second Int. Orn. Congress, Budapest, 1891 (Ibis, 1891, pp. 514-527).

393. Sclater and Shelley on the Scansores and Coccyges. <Auk, IX, p. 184, April, 1892.

Review of Vol. XIX of British Museum Catalogue of Birds.

394. Hartert's Catalogue of the Birds in the Museum of the Senkenberg Natural History Society. <Auk, IX, p. 185, April, 1892.

Review of the work (8vo, Frankfort a. M., Jan., 1891).

395. Leverkuhn's 'Fremde Eier im Nest.' <Auk, IX, pp. 185-186, April, 1892.

Notice of Paul Leverkühn's work of this title (8vo, Berlin, 1891).

396. Jäckel's Birds of Bavaria.<Auk, IX, p. 186, April, 1892.

Notice of Andreas Johannes Jäckel's work on this subject (8vo, München und Leipzig, 1891).

397. The North American Species of Colaptes, considered with special reference to the Relationships of C. auratus and C. cafer. $<$ Bull. Amer. Mus. Nat. Hist., IV, 1892, pp. 21-44, and map, March 8, 1892.

Hybridization on a large scale shown to obtain between $C$. auratus and C. cafer.

398. The Blackfronted Warbler (Dendroica nigrifrons Brewst.). $<A u k$, IX, p. 207, April, 1892.

Explanatory note respecting a colored plate of this species published in the preceding number of The Auk (IX, pl. i, Jan., 1891)

399. Salvadori's Catalogue of the Parrots. <Auk, IX, pp. 277-279, July, 1892.

Review of Vol. XX of the British Museum Catalogue of Birds, with critical nomenclatural comment.

400. Oustalet on the Birds of Patagonia. <Auk, IX, p. 281, July, 1892.

Review of the 'Oiseaux' of the Mission Scientifique du Cap Horn (4to, pp. 341, pll. 6).

401. Stone on the Crows, Birds of Paradise, and Orioles in the Museum of the Philadelphia Academy of Natural Sciences. <Auk, IX, p. 282, July, 1892.

Review of Witmer Stone's paper in Proc. Acad. Nat. Sci. Philadelphia, 1891, pp. 441-450.

402. The Wanton Destruction of Bird Life in America. <Our Animal Friends, XIX, pp. 126-128, 150-152, Feb. and March, 1892.

403. Notice of some Venezuelan Birds Collected by Mrs. H. H. Smith. <Bull. Amer. Mus. Nat. Hist., IV, 1892, pp. 51-59, April, 6, 1892.

48 species and subspecies, the following new: (1) Ramphocoelus atrosericeus capitalis, p. 51 ; (2) Lophotriccus subcristatus, p. 53; (3) Picumnus obsoletus, p. 55.

404. Description of a New Gallinule from Gough Island. <Bull. Amer. Mus. Nat. Hist., IV, 1892, pp. 57-58, May 9, 1892.

Porphyriornis comeri, gen. et sp. nov.

405. Bendire's 'Life Histories of North American Birds.' <Auk, IX, pp. 375-376, Oct., 1892.

Review of Part I of this work (4to, Special Bulletin, U. S. Nat. Mus., 1892). 
406. Ridgway's 'The Hummingbirds.' <Auk, IX, pp. 376-377, Oct., 1892. Review of paper published in Rep. U. S. Nat. Mus. for 1890, pp. 255-383, pll. i-xliii.

406a. Merriam on the Life Areas of North America.<Auk, IX, pp. 377-382, Oct., 1892.

Review of Dr. Merriam's Presidential Address before the Biological Society of Washington, Feb. 6, 1892, entitled 'The Geographic Distribution of Life in North America with Special Reference to the Mammalia' (in Proc. Biol. Soc. Washington, VII, pp. 1-64).

407. Suchetet on Hybridity in Birds. <Auk, IX, pp. 382-383, Oct., 1892.

Review of 'Les Oiseaux Hybrides rencontrés à l'état sauvage par André Suchetet.' Troisieme Partie. Les Passereaux.

408. On a Collection of Birds from Chapada, Matto Grosso, Brazil, made by Mr. H. H. Smith, Part II, Tyrannidæ. < Bull. Amer. Mus. Nat. Hist., IV, pp. 331350, Dec., 1892.

\section{3.}

409. British Museum Catalogue of the Picariæ. <Auk, X, pp. 66-69, Jan., 1893. Review of Vols. XVI and XVII of Catalogue of Birds in the British Museum.

410. Cory's 'Catalogue of West Indian Birds.' < Auk, X, pp. 69-70, Jan., 1893.

Review of the 1st ed. (4to, Boston, 1892).

411. Dixon's 'The Migration of Birds.' <Auk, X, 70-73, Jan., 1893.

Review, with extended critical comment, of Charles Dixon's 'The Migration of Birds, an attempt to reduce Avian Season-Flight to Law (8vo, London, 1892).

412. [Pterylography - A Neglected Branch of Ornithology.] <Auk, X, pp. 94-95, Jan., 1893.

Remarks supplementary to an article of this title by Hubert Lyman Clark.

413. The Geographical Origin and Distribution of North American Birds, considered in Relation to Faunal Areas of North America. $<A u k$, X, pp. 97150, pll. iii-v (maps), April, 1893.

414. Keeler on the 'Evolution of the Colors of North American Land Birds.' $<A u k$, X, pp. 189-195, April, 1893.

Review of Charles A. Keeler's work of this title (8vo, San Francisco, 1893), with much critical commentary.

415. Beddard's 'Animal Coloration.' < Auk, X, pp. 195-199, April, 1893.

Review of Frank E. Beddard's 'Animal Coloration, an Account of the Principal Facts and Theories relating to the Colors and Markings of Animals' (8vo, London, 1892).

416. Hawks and Owls in their Relation to Agriculture.<Auk, X, pp. 199-201, April, 1893.

Review of Dr. A. K. Fisher's work of this title, forming Bull. No. 3, Division of Orn. and Mam., U. S. Dept. Agriculture.

417. Bolles's 'Chronicles.' <Auk, X, pp. 201-202, April, 1893.

Review of Frank Bolles's 'At the North of Bear-camp Water: Chronicles of a Stroller in New England from July to December' (12mo, Boston and New York, 1893). 
418. Foster's Bibliography of the Ornithological Writings of George N. Lawrence. $<$ $A u k, \mathrm{X}$, p. 202, April, 1893.

Review of L. S. Foster's work of this title (Bull. No. 40, U. S. National Museum, 1892).

419. Ornithology of the Death Valley Expedition. <Auk, X, pp. 285-288, July, 1893.

Review of Part II (Report on the Birds, by A. K. Fisher), of the Death Valley Expedition, a Biological Survey of Parts of California, Nevada, Arizona, and Utah (North Amer. Fauna, No. 7, May 31,1893$)$.

420. The Faunal Position of Lower California. <Auk, X, pp. 306-307, July, 1893.

Reply to remarks by Dr. C. Hart Merriam under the same title (l. c., pp. 305, 306).

421. Shufeldt on Fossil Birds from Oregon. <Auk, X, pp. 343-345, Oct., 1893.

Review of 'A Study of the Fossil Avifauna of the Equus Beds of the Oregon Desert,' by Dr. R. W. Shufeldt (in Journ. Acad. Nat. Sci. Philadelphia, XI, pp. 389-425, pll. xv-xvii).

422. Shufeldt on Ichthyornis, and on the Classification of the Longipennes. $<A u k$, X, p. 345, Oct., 1893.

Notice of two papers by Dr. R. W. Shufeldt (Journ. Anat. and Phys., XXVII, pp. 336-342, and Amer. Nat., 1893, pp. 233-237).

423. The Affinities of Hummingbirds and Swifts. <Auk, X, pp. 345-346, Oct., 1893.

Notice of papers hy R. Ridgway, R. W. Shufeldt, and F. A. Lucas on this subject.

424. Food Habits of Birds. <Auk, X, p. 347, Oct., 1893.

Notice of papers on this subject by W. B. Barrows and F. E. L. Beal in Dr. C. Hart Merriam's 'Report of the Ornithologist and Mammalogist' for 1892 (Rep. Secretary of Agriculture for 1892, pp. 181-200).

425. Hasbrouck on 'Evolution and Dichromatism in the Genus Megascops.' <Auk, X, pp. 347-351, Oct., 1893.

Critical review of E. M. Hasbrouck's paper on this subject in Amer. Nat., 1893, pp. 521$533,638-649$.

426. Cook's 'Birds of Michigan.' <Auk, X, pp. 351-352, Oct., 1893.

Review of A. J. Cook's 'Birds of Michigan,' (Bull. 94, Michigan Agric. Station, State Agric. College).

427. Averill's List of the Birds of Bridgeport. <Auk, X, pp. 352-353, Oct., 1893.

Notice of a brochure by C. K. Averill, Jr. (8vo, pp. 19, 1892).

428. Summer Birds of Greene County, Pa. <A $u k$, X, p. 353, Oct., 1893.

Notice of a brochure of this title, by J. W arren Jacobs (8vo, pp. 15, 1893).

429. Nutting's Zoölogical Explorations on the Lower Saskatchewan River. $<A u k$, X, pp. 353-354, Oct., 1893.

Notice of C. C. Nutting's 'Report' on his Explorations, etc. (Bull. Lab. Nat. Hist. Iowa State Univ., II, No. 3, pp. 235-293, Jan., 1893).

430. 'A New List of Chilian Birds.' <Auk, X, p. 354, Oct., 1893.

Notice of H. B. James and P. L. Sclater's work of this title (roy. 8vo, London, 1892).

431. Newton's 'A Dictionary of Birds.' Part I. <Auk, X, pp. 357-360, Oct., 1893. Extended review of the first part (A-Ga; 8vo, London, 1893). 
432. On a Collection of Birds from Chapada, Matto Grosso. Parts III and IV, Pipridæ to Rheidæ.<Bull. Amer. Mus. Nat. Hist., V, 1893, pp. 107-158, July 19, 1893.

Spp. and subspp. nov: (1) Pygmornis chapadensis, pp. 122; (2) Piaya cayana cabanisi, p. 136; (3) Buteo albicaudatus sennetti, p. 144;

This concludes the paper, which comprises a list of 324 species, with annotations and comment on allied species in a number of groups. Part IV (pp. 152-158), 'Oological Notes,' contains notes on the nests and eggs of 27 species.

433. Coreba versus Certhiola. <Auk, X, pp. 369-370, Oct., 1893.

Coreba antedates Certhiola by 28 years, with C. flaveola as type by monotypy.

434. The Evolution of the Colors of North American Land Birds. $<A u k, \mathrm{X}, \mathrm{pp}$. 377-380, Oct., 1893.

Reply to Mr. Keeler's rejoinder (l.c., pp. 375-377) to a review of his 'Evolution of Colors in North American Land Birds' (Auk. X, pp. 189-195; see supra, No. 414).

435. Nehrling's 'Our Native Birds of Song and Beauty.' <A uk, X, p. 387, Oct., 1893.

Brief notice of Volume I (4to).

436. List of Mammals and Birds Collected in Northeastern Sonora and Northwestern Chihuahua, Mexico, on the Lumholtz Archæological Expedition, 1890-92.<Bull. Amer. Mus. Nat. Hist., V, 1893, pp. 27-42.

Annotated list of 162 specjes of birds.

1894.

437. Newton's 'A Dictionary of Birds.' Part II. <Auk, XI, pp. 56-60, Jan., 1894. Review of Part II (Ga-Moa). (8vo, London, 1893.) (See supra, No. 431.)

438. Salvadori's Catalogue of the Pigeons. <Auk, XI, pp. 60-62, Jan., 1894.

Review of Vol. XXI of the British Museum Catalogue of Birds, with comment on nomenclatural points.

439. Elliot's Monograph of the Pittidæ. Parts I and II. $<A u k$, XI, pp. 62-63, Jan., 1894.

Review of D. G. Elliot's work of this title, 2d ed. (foljo, London, April, 1893).

440. Sharpe on the Zoögraphical Areas of the World. $<A u k$, XI, pp. 63-65, Jan., 1894.

Review of R. Bowdler Sharpe's paper on this subject (Nat. Sci., III, Aug., 1893, pp. 100108). "But the recognition and definition of an Arctic Zone, or 'Realm,' as Mr. Allen calls it, is a fact which must henceforward be admitted by all ornithologists."

441. Non-significance of albinistic eggs of the Marsh Wren. $<A u k$, XI, p. 81, ${ }^{7} \mathrm{Jan}$., 1894.

Comment on theoretical suggestions of Dr. L. B. Bishop.

442. First Plumages. $<A u k$, XI, pp. 91-93, pl. ii, Jan., 1894.

Seiurus aurocapillus, ad. and juv.

443. Anthony on the Birds of San Pedro Martir, Lower California. $<A u k$, XI, pp. 167-168, April, 1894.

Review of A. W. Anthony's paper of this title (Zoe, IV, pp. 228-247). 
444. Short's Birds of Western New York. <Auk, XI, p. 168, April, 1894.

Notice of Ernest H. Short's brochure of this title (8vo, Chili, N. Y., pp. 13, 1893).

445. Ridgway on the Genus Myiarchus, etc. <Auk, XI, pp. 168-170, April, 1894.

Notice of five papers on American birds, by R. Ridgway, in Proc. U. S. Nat. Mus., XVI, pp. $605-614,663-686$.

446. Stejneger on Japanese Birds. <Auk, XI, p. 170, April, 1894.

Notice of Stejneger's 'Third Instalment of Japanese Birds,' etc. (Proc. U. S. Nat. Mus., XVI, 1893, pp. 615-638).

447. Ogilvie-Grant's 'Catalogue of the Game Birds.' $<A u k$, XI, pp. 171-173, April, 1894.

Review of Vol. XXII of the British Museum Catalogue of Birds, 1893, with critical comment.

448. McIlwraith's 'Birds of Ontario.' <Auk, XI, pp. 240-241, July, 1894.

Review of Thomas Mcllwraith's work of this title, 2d ed. (8vo, Toronto, 1894).

449. Sharpe's Catalogue of the Fulicariæ and Alectorides. <Auk, XI, pp. 242-243, July, 1894.

Review, with critical comment, of Vol. XXIII of the British Museum Catalogue of Birds (1894).

450. Elliot's Monograph of the Pittidæ. Part III. <Auk, XI, p. 243, July, 1894.

Notice of Part III, Feb., 1894. (Cf. supra, No. 439.)

451. Mrs. Wright's 'The Friendship of Nature.' <Auk, XI, p. 314, Oct., 1894.

Notice of Mrs. Mabel Osgood Wright's book of this title (8vo, New York and London, 1894).

452. Shufeldt's 'Comparative Oölogy of North American Birds.' $<A u k$, XI, pp. 314-315, Oct., 1894.

Critizcal notice of R. W. Shufeldt's paper of this title, in Report U. S. Nat. Mus. for 1892 (1894), pp. 461-493.

453. Stone on Old World Rallinæ. <Auk, XI, p. 317, Oct., 1894.

Notice of Witmer Stone's 'Review of Old World Rallinæ,' in Proc. Acad. Nat. Sci. Phila. delphia, 1894, pp. 130-149.

454. Wallace on "Palæarctic" and "Nearctic."<Auk, XI, pp. 318-319, Oct., 1894.

Critical review of A. R. Wallace's 'Palæarctic and Nearctic Regions compared as regards the Families and Genera of their Mammalia and Birds' (Nat. Sci., IV, 1894, pp. 435-445).

455. [Notice of George K. Cherrie's ornithological work in Costa Rica]. $<A u k$, XI, p. 340, Oct., 1894.

"Mr. Cherrie has made an enviable record for himself in Costa Rica, displaying an energy and a capacity for work rarely equalled."

456. Fashion Journals and Bird Destruction. <Auk, XI, p. 342, Oct., 1894.

Comment on an article in Harper's Bazaar of Aug. 18, 1894.

1895 .

457. Elliot's Monograph of the Pittidæ. Part IV. $<A u k$, XII, pp. 65-66, Jan., 1895.

Review of Part IV, issued September, 1894. (Cf. supra, Nos. 439, 450.) 
458. Two Popular Bird Books. <Auk, XII, pp. 66-67, Jan., 1895.

Review of 'In Bird Land,' by Leander S. Keyser, and 'The Birds' Calendar,' by H. E. Parkhurst.

459. Ridgway on New Birds from the Galapagos Islands. $<A u k$, XII, pp. 70-71, Jan., 1895.

Review of R. Ridgway's 'Descriptions of Twenty-two new Species of Birds from the Galapagos Islands' (Proc. U. S. Nat. Mus., XVII, pp. 357-370).

460. Lucas on the Affinities of the Cœrebidæ. $<A u k$, XII, pp. 71-72, Jan., 1895.

Review of F. A. Lucas's paper 'Notes on the Anatomy and Affinities of the Corebidæ and other American Birds' (Proc. U. S. Nat. Mus., XVII, pp. 299-312).

461. Rhoads's Reprint of Ord's North American Zoölogy. <Auk, XII, pp. 72-73, Jan., 1895.

Review of S. N. Rhoads's reprint of George Ord's 'Zoölogy' in Guthrie's Geography (8vo, Haddonfield, N. J., 1894).

462. Reichenow's Birds of German East Africa. <Auk, XII, pp. 73-74, Jan., 1905. Review of Dr. A. Reichenow's 'Die Vögel Deutsch-Ost-Afrikas' (roy. 8vo, Berlin, 1894).

463. [Work of Dr. C. Hart Merriam, as Ornithologist and Mammalogist of U. S. Dept. of Agric. for 1893.]<Auk, XII, p. 98, Jan., 1895.

Notice of his 'Report' for the year 1893.

464. Shufeldt on the Osteology of Cranes and Rails. $<A u k$, XII, pp. 172-173, April, 1895.

Notice of R. W. Shufeldt's paper on this subject in Journ. Anat. and Phys., XXIX, 1894, pp. 21-34.

465. Newton's 'A Dictionary of Birds.' Part III. <Auk, XII, pp. 169-170, April, 1895.

Notice of Part. III (Moa-Sheathbill), 1894. (See supra, Nos. 431 and 437.)

466. Grundtvig on the Birds of Shiocton, Wisconsin. $<A u k$, XII, p. 173, April, 1895.

Notice of F. L. Grundtvig's paper in Trans. Wisconsin Acad. Sci. Arts, and Letters, X, $\cdot 1894$, pp. $73-184$.

467. Bourns and Worcester on the Birds of the Philippines. $<A u k$, XII, pp. 173174, Auk, 1895.

Review of their paper in Occas. Papers of Minnesota Acad. Nat. Sci., I, No. 1, Dec. 1894.

468. Merriam's Laws of Temperature Control of the Distribution of Land Animals and Plants. $<A u k$, XII, pp. 172-173, April, 1895.

Review of Dr. C. Hart Merriam's paper of this title in Nat. Geogr. Mag., VI, 1834, pp. 229-238, pll. xii-xiv.

469. Minot's Land-Birds and Game-Birds of New England. Second Edition. $<A u k$, XII, pp. 284-286, July, 1895.

Review of the second edition of H. D. Minot's work, edited by William Brewster (8vo, Boston and New York, 1895).

470. Clark on the Pterylography of North American Goatsuckers and Owls. $<A u k$, XII, pp. 287-288, July, 1895. 1895).

Review of Hubert Lyman Clark's paper (Proc. U. S. Nat. Mus., XVII, pp. 551-572, June. 
471. Sharpe and Wyatt's Monograph of the Swallows. $<A u k$, XII, pp. 373-375, Oct., 1895.

Review, with critical comment, of their 'A Monograph of the Hirundinidæ, or Family of Swallows' (2 vols., 4to, London, 1885-1894).

472. Food Habits of Woodpeckers. <Auk, XII, pp. 380-381, Oct., 1895.

Review of F. E. L. Beal's 'Preliminary Report on Woodpeckers,' and F. A. Lucas's 'The Tongues of Woodpeckers,' forming Bull. No. 7, U. S. Dept. Agric., 1895.

473. Barrows and Schwarz on the Food of the Common Crow. $<A u k$, XII, pp. 381383, Oct., 1895.

Review of Bull. No. 6, Dept. of Agric., 1895.

474. Forbush on 'Birds as Protectors of Orchards.' $<A u k$, XII, pp. 383-384, Oct., 1895.

Review of E. H. Forbush's paper in Massachusetts Crop Report for July, 1895.

475. Suchetet on Hybridity in Birds. <Auk, XII, p. 384, Oct., 1895.

Review of Part V of André Suchetet's 'Les Oiseaux Hybrides rencontrés à l'état sauvage' (9vo, pp. 473-\$73, Lille, 1895). (See supra, No. 407.)

1896.

475a. Elliot's 'Monograph of the Pittidæ.'<Auk, XIII, pp. 60-61, Jan., 1896.

Review of the concluding Part V, with a summary notice of the completed work (folio, London, 1893-1895). (See supra, Nos. 439, 450, 457.)

477. A. O. U. Check-List of North American Birds, Second Edition. <Auk, XIII, pp. 69-70, Jan., 1896.

Comparison with the first edition (1886).

478. 'Progress in American Ornithology, 1886-95.' <Science, N. S., III, Nos. 73 and 75, pp. 777-779 and 842-843, May 22 and June 5, 1896.

Relates to the Second Edition of the A. O. U. Check-List of North American Birds, in reply to criticisms by Dr. R. W. Shufeldt in the American Naturalist (XXX, May, 1896, pp. 357-372), and Science (III, pp. 841-842, June 5, 1896).

479. Bendire on the Cowbirds. <Auk, XIII, pp. 71-72, Jan., 1896.

Review of Capt. Charles Bendire's 'The Cowbirds,' in Report U. S. Nat. Mus. for 1893 (1895), pp. 587-624, pll. i-iii.

480. Lucas on the Weapons and Wings of Birds. $<A u k$, XIII, p. 72, Jan., 1896.

Review of Frederic A. Lucas's paper in Report of U. S. Nat. Mus. 1893 (1895), pp. 653663.

481. Fisher's Hawks and Owls from the Standpoint of the Farmer. $<A u k$, XIII, p. 73, Jan., 1896.

Review of Dr. A. K. Fisher's paper by this title, in Yearbook U. S. Dept. Agric. for 1894 (1895), pp. 215-232.

482. Beddard's 'Text-book of Zoögeography.' <Auk, XIII, pp. 73-75, Jan., 1896.

Review of Frank E. Beddard's work of this title (8vo, Cambridge, 1895), with critical comment. 
483. [The Taxonomic Value of the Tongue in Birds].<Auk, XIII, pp. 114-115, April, 1896.

Note to an article with this title (l. $c .$, pp. 109-114) by Frederic A. Lucas.

484. Gätke's 'Heligoland.' <Auk, XIII, pp. 137-153, April, 1896.

An extended critical review of the work, and of Gätke's views on bird migration, change of color in feathers without moult, etc.

485. The 'Birds' of 'The Royal Natural History.' <Auk, XIII, pp. 156-160, 252253, April and July, 1896.

Review of the bird part (Vols. III and IV) of 'The Royal Natural History,' edited by Richard Lydekker (roy. 8vo, London, 1894-95).

486. Saunders and Salvin's Catalogue of the Gaviæ and Tubinares. <Auk, XIII, pp. 160-162, April, 1896.

Review, with comment on points of nomenclature, etc., of Vol. XXV, of the British Museum Catalogue of Birds.

487. Salvadori's Catalogue of the Chenomorphæ, Crypturi, and Ratitæ. $<A u k$, XIII, pp. 162-164, April, 1896. Birds.

Review, with technical comment, of Vol. XXVII of the British Museum Catalogue of

488. Loomis on California Water Birds. <Auk, XIII, p. 168, April, 1896.

Review of Leverett M. Loomis's 'California Water Birds, No. II,' in Proc. California Acad. Sci. (2), VI, 1896, pp. 1-30.

489. [Some Questions of Nomenclature]. <Auk, XIII, pp. 187-190, April, 1896.

In response, by request, to Mr. Witmer Stone's paper of this title (l. c., pp. 183-187).

490. [The Seebohm Collection of Birds]. <Auk, XIII, pp. 195-196, April, 1896.

Notice of its extent and its transfer to the British Museum. Based on an article in Nature (Feb. 20, 1896).

491. Stone on Birds Collected in North Greenland. <Auk, XIII, p. 243, July, 1896.

Notice of Witmer Stone's paper in Proc. Acad. Nat. Sci. Philadelphia, 1895, pp. 502-505.

492. Schalow on a Collection of Birds from West Greenland. <Auk, XIII, pp. 243-244, July, 1896.

Review of a paper by Herman Schalow in Journ. f. Orn., 1895, pp. 475-481.

493. Rotzell's Birds of Narberth, Pa., and Vicinity. <Auk, XIII, p. 244, July, 1896. Review of Dr. W. E. Lotzell's brochure of 8 pp. (1895).

494. Rhoads's List of Tennessee Birds. <Auk, XIII, pp. 244-245, July, 1896.

Review of paper by S. N. Rhoads in Proc. Acad. Nat. Sci. Philadelphia, 1895, pp. 463-501.

495. Short's Birds of Western New York. <Auk, XIII, p. 245, July, 1896.

Review of Ernest H. Short's second edition of his 'Birds of Western New York' (8vo, pp. 20, 1896.) (See supra, No. 444.)

496. Cory's 'Hunting and Fishing in Florida,' with a 'Key to the Water Birds of the State.' < Auk, XIII, pp. 246-247, July, 1896.

Review of the work (sm. quarto, Boston, 1896). 
497. Howe's 'Every Bird.' < Auk, XIII, p. 247, July, 1896.

Review of Reginald Heber Howe, Jr's., work of this title (sm. 8vo, Boston, 1896).

498. Winchell's 'Evolution of Bird Song.' < Auk, XIII, pp. 249-250, July, 1896.

Review of Charles A. Winchell's work of this title (8vo, London and New York).

499. Harvey-Brown and Buckley's 'A Vertebrate Fauna of the Moray Basin.' < $A u k$, XIII, pp. 251-252, July, 1896.

Review of the work (sm. 4to, Edinburgh, 1895).

500. The Origin and Relations of the Floras and Faunas of the Antarctic and adjacent Regions. Vertebrata of the Land; Birds and Mammals. <Science (2), III, No. 61, pp. 317-319, Feb. 28, 1896.

Birds offer no satisfactory evidence of a former "Antarctic Continent."

501. Alleged Changes of Color in the Feathers of Birds without Molting. <Bull. Amer Mus. Nat. Hist., VIII, pp. 13-44, March 18, 1896.

"It is a summary and criticism of the work of some of the more important writers upon the subject of color changes in feathers without moult, and it deals unsparingly with those who have asserted as possible the complete rejuvenation of an abraded feather...."-J. Dwight, Jr., in Auk, XIII, pp. 166-167, April, 1896.

502. Schwann's Handbook of British Birds. <Auk, XIII, pp. 328-329, Oct., 1896. 1896).

Review of H. Kirke Schwann's 'Concise Handbook of British Birds' (16mo, London,

503. Ridgway and Lucas on a New Family [Procniatidæ] of Birds. $<A u k$, XIII, pp. 334-335, Oct., 1896.

Review of two papers on this subject by R. Ridgway and F. A. Lucas, in Proc. U. S. Nal. Mus., XVIII, pp. 450, and 505-507.

504. Montgomery on Migration as a Check upon Geographic Variation. $<A u k$, XIII, p. 335, Oct., 1896.

Review of a paper by Thomas H. Montgomery, Jr., in Amer. Nat., 1896, pp. 458-464.

505. Contributions to Economic Ornithology. <Auk, XIII, pp. 335-338, Oct., 1896.

Notice of papers by S. D. Judd, F. E. L. Beal, E. H. Forbush, and Miss F. A. Merriam.

1897.

506. Sharpe's Catalogue of the Limicolæ. <Auk, XIV, pp. 102-104, Jan., 1897.

Review of Vol. XXIV of the British Museum Catalog ue of Birds, 1896.

507. Bendire's 'Life Histories of North American Birds.' < Auk, XIV, pp. 104-106, Jan., 1897.

Review of Part II of Capt. Charles E. Bendire's important work. (See supra, No. 405).

508. Miss Merriam's 'A-Birding on a Bronco.' < Auk, XIV, pp. 107-108, Jan., 1897.

Review of Miss Florence A. Merriam's work of this title (16mo, Boston and New York, 1896).

509. 'Papers Presented to the World's Congress of Ornithology.' $<A u k, \mathrm{XIV}, \mathrm{p}$. 108, Jan., 1897.

Review of a volume thus entitled, and edited by Mrs. E. Irene Rood (8vo, Chicago, 1896). 
510. The Revised New Nuttall. <Auk, XIV, p. 109, Jan., 1897.

Review of Montague Chamberlain's second and revised ed. of Nuttall's Ornithology (2 vols., 8vo, Boston, 1896). (Cf. supra, No. 381.)

511. Wintle's 'Birds of Montreal.' <Auk, XIV, p. 112, Jan., 1897.

Review of Ernest D. Wintle's work of this title (8vo, Montreal, 1896).

512. Oberholser's Birds of Wayne County, Ohio. $<A u k$, XIV, pp. 112-113, Jan., 1897.

Review of H. C. Oberholser's 'A Preliminary List of the Birds of Wayne County, Ohio' (Bull. Ohio Agric. Exper. Station, tech. ser., I, No. 4, July, 1896, pp. 243-354).

513. Ridgway's 'Manual of North American Birds.' <Auk, XIV, pp. 232-233, April, 1897.

Review of the $2 d$ ed. (roy. 8 vo, Philadelphia, 1896).

514. Goode's 'The Published Writings of Philip Lutley Sclater.' <Auk, XIV, pp. 233-234, April, 1897.

Review of Bull. No. 49, U. S. Nat. Mus., 1896.

515. Bates's 'The Game Birds of North America.' <Auk, XIV, p. 244, April, 1897.

Review of the work (16mo, Boston, 1896).

516. Butler on 'A Century of Change in the Aspects of Nature in Indiana.' $<A u k$, XIV, p. 245, April, 1897. $31-42$.

Notice of A. W. Butler's paper of this title in Proc. Indiana Acad. Sci., No. V, 1895, pp.

517. Elliot's Catalogue of a Collection of Birds from Somali-Land. $<A u k$, XIV, p. 245, April, 1897.

Notice of D. G. Elliot's paper of this title in Field Mus. Publ., Orn. Ser., I, No. 2, 1897, pp. 29-67).

518. Anderson's Birds of Winnebago and Hancock Counties, Iowa. <Auk, XIV, p. 246, April, 1897.

Notice of Rudolph M. Anderson's privately printed brochure, 16mo, pp. ii +19 , Forest City, Iowa, 1897.

519. Ricker's Notes on the Birds of Hull, Mass. <Auk, XIV, p. 246, April, 1897.

Brief notice of Everett W. Ricker's privately printed paper of this title (16mo, Newtonville, Mass., 1896).

520. Howe's Birds of Brookline, Mass. <Auk, XIV, p. 246, April, 1897.

Notice of paper of this title by Reginald Heber Howe, Jr. (privately printed, folio, 2 pp., Jan., 1897).

521. Tegetmeier's 'Pheasants.' <Auk, XIV, pp. 426-427, April, 1897.

Review of the third edition of W. B. Tegetmeier's work of this title (8vo, London, 1897).

522. Cory's List of the Birds of Eastern North America. <Auk, XIV, p. 248, April, 1897.

Review of C. B. Cory's work of this title (8vo, Boston, 1896).

523. Schalow's the Published Writings of Anton Reichenow. $<A u k, \mathrm{XIV}$, p. 248, April, 1897.

Notice of the work (8vo, pp. 29, 1896). 
523a. The Fate of some Carrier Pigeons. <Forest and Stream, XLVIII, p. 383, 1897.

524. The Proper Generic Name of the Loons. <Auk, XIV, p. 312, July, 1897.

Gavia Forster should replace Urinator Cuvier.

525. Ridgway's Birds of the Galapagos Archipelago. $<A u k$, XIV, pp. 329-330, July, 1897.

Review of R. Ridgway's monographic paper in Proc. U. S. Nat. Mus., XIX, pp. 459-670.

526. Cooke's 'Birds of Colorado.' <Auk, XIV, pp. 331-332, July, 1897.

Review of W. W. Cooke's paper of this title in Bull. No. 37, Colorado State Agric. College, pp. 143, March 17, 1897.

527. Miller on Construction of Scientific Names. <Auk, XIV, pp. 332-333, July, 1897.

Review of Prof. Walter Miller's paper on this subject (Proc. California Acad. Sci., 3d ser., I, No. 3, pp. 115-143).

528. The New York Zoölogical Society.<Auk, XIV, p. 344, July, 1897.

Announcement of its organization.

529. Cory's Shore Birds of North America. < Auk, XIV, pp. 418-419, Oct., 1897.

Notice of C. B. Cory's work of this title (sm. 4to, Boston, 1897).

530. Hartert on the Podargidæ, Caprimulgidæ and Macropterygidæ. $<A u k$, XIV, pp. 419-420, Oct., 1897.

Review of Ernest Hartert's monographs of these families (in 'Das Tierreich,' Lief. 1).

531. Papers on Economic Ornithology. <Auk, XIV, pp. 420-422, Oct., 1897.

Review of S. D. Judd's 'Methods in Economic Ornithology with Special reference to the Catbird'; F. E. L. Beal's 'The Blue Jay and its Food,' and his 'Some Common Birds in their Relation to Agriculture'; and Dr. T. S. Palmer's 'Extermination of Noxious Animals by Bounties.'

532. Whitlock's Review of Herr Gätke's Views on the Migration of Birds. $<A u k$, XIV, pp. 422-424, Oct., 1897.

Review of F. B. Whitlock's work on Herr Gätke's 'Views,' etc. (8vo, London, 1897), with excerps from his criticisms of Herr Gätke's theories and assumptions.

533. Suchetet on Hybrids among Wild Birds. <Auk, XIV, pp. 424-425, Oct., 1897.

Review of the completed work 'Des Hybrides à l'état sauvage,' by André Suchetet. (Large 8vo, Paris, 1897; see supra, Nos. 407, 475).

534. Birds and Millinery. <New York Times, Nov. 21, 1897.

Reply to an editorial on this subject in the New York Times, of Nov. 19, 1897.

535. An Ornithologist's Plea. <New York Times, Nov. 25, 1897.

Reply to criticism by 'A. B. C.' on the work of the Audubon Societies, in the New York Times of Nov. 22, 1897.

536. Heron Farming for Aigrettes. <New York Times, Nov. 29, 1897.

Exposure of the report of an alleged heron farm in Tuuis, cited in the New York Times of Nov. 23 and 26, 1897. 
537. Dixon's Migration of Birds. <Auk, XV, pp. 67-70, Jan., 1898.

Review of Charles Dixon's 'The Migration of Birds,' etc., "amended" edition (8vo, London, 1897). Critical notice of his theories of the origin and causes of migration. (Cf. supra, No. 411.)

538. Marsh on 'The Affinities of Hesperornis.' <Auk, XV, p. 70, Jan., 1898.

Critical notice of O. C. Marsh's paper in Amer. Journ. Sci., III, pp. 347-348, April, 1897.

539. Stone on the Genus Sturnella. $<A u k$, XV, p. 70, Jan., 1898.

Notice of Witmer Stone's paper in Proc. Acad. Nat. Sci. Philadelphia, 1897, pp. 146-152.

540. The Proper Name of the Western Horned Owl. <Auk, XV, p. 71, Jan., 1898. Review of Witmer Stone's paper on this subject in Amer. Nat., March, 1897, p. 236.

541. Baskett's 'Story of the Birds.' <Auk, XV, pp. 71-72, Jan., 1898.

Review of James Newton Baskett's work of this title (12mo, New York, 1897).

542. Grinnell on the Birds of Santa Barbara, San Nicolas and San Clemente Islands, California. <Auk, XV, p. 73, Jan., 1898.

Notice of paper by J. Grinnell in Publ. No. I, Pasadena Acad. Sci., pp. 26, Aug., 1897.

543. [New York Zoölogical Society.]<Auk, XV, pp. 79-80, Jan., 1898. Its plans and progress.

544. 'Audubon and His Journals.' <Auk, XV, pp. 198-205, April, 1898.

Review of Miss Maria R. Audubon's work of this title (2 vols., 8vo, New York, 1897).

545. Miss Merriam's 'Birds of Village and Field.' <Auk, XV, p. 206, April, 1898. 1898).

Review of Miss Florence A. Merriam's work of this title (12mo, Boston and New York,

546. 'Hair and Feathers.' <Auk, XV, p. 207, April, 1898.

Review of paper by J. S. Kingsley of this title in Amer. Nat., XXXI, pp. 767-777, figs. 1-14, Sept., 1897.

547. Bauer on the Birds of the Galapagos Archipelago. $<A u k, \mathrm{XV}$, pp. 207-208, April, 1898.

Review of G. Bauer's paper on Galapagos birds in Amer. Nat., XXXI, 1897, pp. 777-784.

548. Two New Popular Bird Books. <Auk, XV, pp. 275-278, July, 1898.

Review of W. E. D. Scott's 'Bird Studies' (4to, 1898), and of A. C. Apgar's 'Birds of the United States, east of the Rocky Mountains' (sm. 8vo, New York, 1898).

549. Cory's Ducks, Geese and Swans. <Auk, XV, pp. 278-279, July, 1898.

Review of C. B. Cory's 'How to know the Ducks, Geese and Swans of North America' (sm. 4to, Boston, 1897).

550. Worcester and Bourn's Contributions to Philippine Ornithology. $<A u k, \mathrm{XV}$, p. 284, July, 1898.

Review of their paper on Philippine birds in Proc. U. S. Nat. Mus., XX, No. 1143, pp. $549-625,1898$. 
551. Butler's Birds of Indiana. <Auk, XV, pp. 335-336, Oct., 1898.

Review of A. W. Butler's descriptive catalogue, etc., in Rep. State Geologist of Indiana for 1897 , pp. $515-1187$.

552. Blanford's 'Birds of British India.' <Auk, XV, p. 336, Oct., 1898.

Review of Vol. IV of 'The Fauna of British India.'

553. Gurney's 'The Economy of the Cuckoo.' <Auk, XV, pp. 337-338, Oct., 1898.

Review of a paper by J. H. Gurney, published in Norfolk and Norvich Nal. Soc., VI, pp. $365-384$.

554. Eastman on Struthious Birds. <Auk, XV, pp. 338-339, Oct., 1898.

Review of paper by C. R. Eastman, in Bull. Mus. Comp. Zoöl., XXXII, No. 7, pp. 127$144,1898$.

555. Bangs on Birds from Colombia. $<A u k$, XV, p. 339, Oct., 1898.

Notice of two papers by Outram Bangs, in Proc. Biol. Soc. Washington, XV, 1898, pp. 131-144, 157-160.

556. Nelson on New Birds from Mexico. <Auk, XV, pp. 339-340, Oct., 1898.

Notice of two papers by E. W. Nelson, in Proc. Biol. Soc. Washington, XV, 1898, pp. 5-11, $57-68$.

1899.

557. Torrey's 'A World of Green Hills.' <Auk, XV, pp. 86-87, Jan., 1899.

Review of Bradford Torrey's work of this title (16mo, Boston and New York, 1898).

558. Mrs. Maynard's Birds of Washington. <Auk, XVI, pp. 87-88, Jan., 1899.

Review of Mrs. L. W. Maynard's 'Birds of Washington and Vicinity,' etc. (8vo, Washington, 1898).

559. Blanchan's 'Birds that Hunt and are Hunted.' $<A u k$, XVI, pp. 88-89, Jan., 1899.

Review of Neltjie Blanchan's work of this title (8vo, New York, 1898).

560. Huntington's 'In Brush, Sedge, and Stubble.' <Auk, XVI, pp. 89, 372-373, Jan. and July, 1899.

Notice of Parts I and II of Dwight W. Huntington's work "thus entitled (folio, Cincinnati, 1898).

561. Oberholser on the Wrens of the Genus Thryomanes. $<A u k$, XVI, pp. 89-90, Jan., 1899.

Notice of H. C. Oberholser's paper in Proc. U. S. Nat. Mus., XXI, No. 1153, pp. 421-450, Nov., 1898 .

562. Bangs on Birds from Colombia. <Auk, XVI, pp. 90-91, Jan., 1899.

Notice of his third paper on Colombian birds (Proc. Biol. Soc. Washington, XII, 1898, pp. 171-192.

563. Proceedings of the Indiana Academy of Science. $<A u k$, XVI, p. 91, Jan., 1899.

Notice of the ornithological papers in the volume for the year 1897.

564. The Osprey. $<A u k$, XVI, pp. 95-213, Jan. and April, 1899.

The transfer of this journal from New York to Washington, changes in its management and editorial control, and comment (l. c., p. 213) on Dr. Gill's views on the classification of birds. 
565. [New York Zoölogical Park.]<Auk, XVI, p. 96, Jan., 1899.

Further account of progress.

566. Volume XXVI of the British Museum Catalogue of Birds. $<A u k$, XVI, pp. 198-203, April, 1899.

Critical review of the volume (by R. Bowdler Sharpe and W. R. Ogilvie-Grant), and a general survey of the whole series (27 volumes) of the 'Catalogue' (1874-1898).

567. [Chuck-will's-widow in Kansas.]<Auk, XVI, p. 187, footnote, April, 1899.

Second authentic record for Kansas. (See further, Auk, XVII, p. 175.)

568. Evans's 'Birds.' <Auk, XVI, p. 203, April, 1899.

Notice of the Bird volume (Vol. IX) by A. H. Evans, of the Cambridge Natural History Series.

569. 'Birds.' <Science, N. S., IX, pp. 647-648, May 5, 1899.

Review of the volume 'Birds,' by A. H. Evans, Cambridge Natural History Series, Vol. IX.

570. Von Ihering's Birds of São Paulo, Brazil. <Auk, XVI, pp. 203-204, April, 1899.

Review of Dr. Von Ihering's 'As A ves do Estad̆o de S. Paulo,' in Revista do Museu Paulista, III, 1899, pp. 113-476.

571. Dearborn's Birds of Belknap and Merrimac Counties, New Hampshire. <Auk, XVI, p. 204, April, 1899.

Notice of Ned Dearborn's 'Preliminary List,' etc. (doctorial thesis, 8vo, Durham, New Hampshire College, 1898).

572. Nash's 'The Birds of Ontario in Relation to Agriculture.' $<A u k$, XVI, pp. 204-205, April, 1899.

Notice of Charles W. Nash's work of this title (8vo, Toronto, 1898).

573. Stejneger on the Birds of the Kurile Islands. <Auk, XVI, p. 205, April, 1899.

Notice of Dr. L. Stejneger's paper of this title (Proc. U. S. Nat. Mus., XXI, pp. 269-296).

574. Clark on 'The Feather Tracts of North American Grouse and Quail.' <Auk, XVI, pp. 205-206, April, 1899.

Paper by Hubert Lyman Clark, in Proc. U. S. Nat. Mus., XXI, pp. 641-654, pll. xlvii-xlix.

575. ['Bird-Lore.']<Auk, XVI, pp. 212-213, April, 1899.

Notice of the inception, character and scope of this new ornithological journal.

576. Elliot's Wild Fowl of North America. <Auk, XVI, pp. 288-289, July, 1899.

Review of D. G. Elliot's 'Wild Fowl of the United States and British Possessions,' etc. (8vo, New York, F. P. Harper, 1898).

577. Thompson's 'Wild Animals I have known.' <Auk, XVI, pp. 289-290, July, 1899.

Review of his book of this title (8vo, New York, 1899).

578. Stone on the Types of Birds in the Collection of the Academy of Natural Sciences of Philadelphia. <Auk, XVI, p. 290, July, 1899.

Summary of Witmer Stone's paper in Proc. Acad. Nat. Sci. Philadelphia, 1899, pp. 5-62.

579. New North American Birds. <Auk, XVI, p. 291, July, 1899.

Nolice of three papers by $O$. Bangs, one by W. Brewster, and one by W. H. Osgood. 
580. Economic Relations of Birds to Agriculture. <Auk, XVI, pp. 294-295, July, 1899.

Notice of papers by F. E. L. Beal, S. D. Judd, and T, S. Palmer.

581. Genera and Subgenera of the A. O. U. Check-List. <Auk, XVI, p. 297, July, 1899.

General comment with reference to a paper on this subject by E. Coues in The Osprey, III, 1899, p. 144 .

582. [A Sophism anent Bird Destruction.]<Auk, XVI, p. 304, July, 1899.

583. Republication of Descriptions of New Species and Subspecies of North American Birds. <Auk, XVI, pp. 338-350, July, 1899.

Includes those given in the 'Ninth Supplement' to the A. O. U. Check-List, and also those published subsequently, down to October, 1899.

584. Montgomery on the Food of Owls. $<A u k$, XVI, pp. 363-364, Oct., 1899.

Review and summary of Thomas H. Montgomery, Jr's., paper on this subject in Amer. Nat., XXXIII, July, 1899, pp. 563-572.

585. D. E. Lantz's 'Review of Kansas Ornithology.' <Auk, XVI, pp. 364-365, Oct., 1899.

Review of his paper in Trans. Kansas Acad. Sci., 1896-97, pp. 224-276 (July, 1897).

586. The Goss Collection of Mexican and Central American Birds. <Auk, XVI, pp. 365-366, Oct., 1899.

Review of D. E. Lantz's paper on Col. N. S. Goss's Collection (Trans. Kansas Acad. Sci., 1896-97, pp. 218-224, July, 1899).

587. C. B. Cory's 'The Birds of Eastern North America. Water Birds, Part I.' $<A u k$, XVI, pp. 366-367, Oct., 1899.

Review of the work (sm. 4to, Field Museum, Chicago, 1899).

588. Edward Knobel's 'Field Key to the Land Birds.' < Auk, XVI, pp. 367-368, Oct., 1899.

Review of the work (12mo, Boston, 1899).

589. Mrs. Olive Thorne Miller's 'The First Book of Birds.' <Auk, XVI, pp. 36S369, Oct., 1899.

Review of the work (12mo, Boston, 1899).

590. Oberholser on Untenable Names in Ornithology. $<A u k$, XVI, p. 370, Oct., 1899.

Notice of H. C. Oberholser's paper of this title (Proc. Acad. Nat. Sci. Philadelphia, 1899 , pp. 201-216).

591. Gurney and Gill on the Age to which Birds Live.<Auk, XVI, pp. 370-372, Oct., 1899.

Review of H. Gurney's (Ibis, Jan., 1899, pp. 19-42) and Theodore Gill's (Osprey, III, 1899 , pp. 157-160) papers on this subject. 
1900.

592. The Little Black Rail. <Auk, XVII, pp. 1-8, pl. i, Jan., 1900.

General history of Porzana jamaicensis.

593. Merriam's Biological Survey of Mount Shasta. <Auk, XVII, pp. 73-74, Jan., 1900.

Review of 'Results of a Biological Survey of Mount Shasta, California,' by C. Hart Merriam (N. Amer. Fauna, No. 16, Oct. 18, 1899).

594. Palmer's 'The Avifauna of Pribilof Islands.' <Auk, XVII, pp. 74-76, Jan., 1900.

Review of Wm. Palmer's paper of this title in Jordan's 'The Fur Seal Islands of the North Pacific' (Part III, 1899, pp. 355-431, pll. xxxviii-xli).

595. Howe and Sturtevant's 'Birds of Rhode Island.' $<A u k$, XVII, pp. 76-77, Jan., 1900.

Review of the work (8vo, Newport, 1899).

596. Cory's 'The Birds of Eastern North America. Part II, Land Birds.' <Auk, XVII, p. 78, Jan., 1900.

Review of C. B. Cory's work of this title (sm. 4to, Field Museum, Chicago, 1899).

597. 'Avium Generum Alphabeticus.' < Auk, XVII, pp. 78-79, Jan., 1900.

Review of the work, published by the British Ornithologists' Club, (Bulletin, Vol. IX, pp. 1-31, 1899).

598. Sharpe's 'Hand-List of the Genera and Species of Birds.' <Auk, XVII, pp. 79-81, Jan., 1900.

Review of Vol. I (8vo, British Museum, 1899).

599. Dubois's 'Synopsis Avium.' <Auk, XVII, p. 81, Jan., 1900.

Notice of fasc. i, of the work (4to, Bruxelles, 1899).

600. Salvadori and Festa on Birds of Ecuador. <Auk, XVII, pp. 81-82, Jan., 1900.

Review of their 'Viaggio del Dr. Enrico Festa nell' Ecuador' (in Boll. Mus. Zool. ed Anat. comp. d. R. Univ. di Torino, Vol. XV, pp. 1-31, 1899).

601. Kellogg's List of Biting Lice (Mallophaga) taken from North American Birds and Mammals. <Auk, XVII, pp. 82-84, Jan., 1900.

Review of Vernon L. Kellogg's paper in Proc. U. S. Nat. Mus., XXII, No. 1183, 1889, pp. $39-100$.

602. Lange's 'Our Native Birds, How to Protect them and Attract them to our Homes.' <Auk, XVII, pp. 85-86, Jan., 1900.

Review of D. Lange's work of this title (12mo, New York and London, 1899).

603. H. A. Macpherson's 'History of Fowling.' <Auk, XVII, pp. 85-86, Jan., 1900.

Review of the work (large 8vo, Edinburgh, 1899).

604. Bumpus on 'The Elimination of the Unfit.' <Auk, XVII, p. 87, Jan., 1900.

Review of Hermon C. Bumpus's paper entitled "The Elimination of the Unfit as illustrated by the Introduced Sparrow Passer domesticus" (in Biol. Lectures of the Marine Biol. Lab., Wood's Holl, Mass., Sess. of 1897-1898, pp. 209-226. 
605. Whitman on 'Animal Behavior.' <Auk, XVII, pp. 87-88, Jan., 1900.

Review of C. O. Whitman's paper in Biol. Lect. of the Marine Biol. Lab., Wood's Holl, Mass., 1898 (1899), pp. 285-338.

606. [Bird Destruction for Millinery Purposes.] <Auk, XVII, pp. 94-96, Jan., 1900. Extended comment on the subject.

607. Keeler's 'Bird Notes Afield.' <Auk, XVII, pp. 180-181, April, 1900.

Review of Charles A. Keeler's work of this title (8vo, San Francisco, 1899).

608. Russell on Birds of the Northwest Territory. $<A u k$, XVII, pp. 181-182, April, 1900.

Review of Frank Russell's 'Explorations in the Far North' (8vo, University of Iowa, 1899. Birds, pp. 253-270).

609. Loomis on California Water Birds. <Auk, XVII, pp. 182-183, April, 1900.

Review of Part IV of L. M. Loomis's series of papers ynder this general title (Proc. California Acad. Sci., 3d Ser., II, pp. 277-322, Feb. 12, 1900).

610. Witmer Stone on 'The Summer Molting Plumage of Certain Ducks.' $<A u k$, XVII, pp. 183-184, April, 1900.

Review of his paper (Proc. Acad. Nat. Sci. Philadelphia, 1899, pp. 467-472).

611. Stark's Birds of South Africa. <Auk, XVII, pp. 189-190, April, 1900.

Review of Vol. I of Arthur C. Stark's 'Birds of South Africa' (8vo, London, 1900).

612. Rothschild and Hartert's 'Review of the Ornithology of the Galapagos Islands.' <Auk, XVII, pp. 300-303, July, 1900.

Review of their paper on this subject (Novitates Zoologicæ, VI, 1899, pp. 85-205).

613. Salvadori and Festa on Birds of Ecuador. $<A u k$, XVII, p. 303, July, 1900.

Review of Parts II and III of their paper on the birds of Ecuador. (See supra, No. 600.)

614. Oberholser on Birds from Central Asia, Madagasear, and Santa Barbara Islands, Cal. <Auk, XVII, pp. 304-305, July, 1900.

Review of three papers by H. C. Oberholser (Proc. U. S. Nat. Mus., XXII, Nos. 11951197, pp. 205-234).

615. Dugmore's 'Bird Homes.' < Auk, XVII, pp. 306-307, July, 1900.

Review of A. R. Dugmore's work thus entitled (8vo, New York, 1900).

615a. 'Bird Homes.'<New York Evening Post, June 26, 1900.

Review of A. R. Dugmore's work of this title. (See supra, No. 615.)

616. Henry J. Pearson's 'Beyond Petsora Eastward.'<Auk, XVII, pp. 307-308, July, 1900.

Review of the work (royal 8vo, London, 1899).

617. Collett and Nansen's Birds of the Norwegian North Polar Expedition. $<A u k$, XVII, pp. 308-310, July, 1900.

Review of section IV, 'An account of the Birds,' of the Norwegian North Polar Expedition of 1893-1896 (4to, Christiania, London, etc., 1899). 
618. Palmer on Legislation for the Protection of Birds. $<A u k$, XVII, pp. 314-315, July, 1900.

Résumé of Dr. T. S. Palmer's report on the subject, forming Bull. No. 12 of the Division of the Biological Survey.

619. [The Outlook for Bird Protection in North America.] < Auk, XVII, pp. 323-324, July, 1900.

620. 'Aptosochromatism.' <Auk, XVII, pp. 327-336, Oct., 1900.

Apropos of papers by F. J. Bertwell, Dr. A. P. Chadbourne, and J. Lewis Bonhote on the alleged change of color in feathers without moult.

621. North American Birds Collected at Santa Marta, Colombia.<Auk, XVII, pp. 363-367, Oct., 1900.

43 species, 16 of them here recorded for the first time from Colombia.

621a. List of Birds collected in the District of Santa Marta, Colombia, by Mr. Herbert H. Smith. <Bull. Amer. Mus. Nat. Hist., XIII, pp. 117-183, Aug. 25, 1900.

An annotated list of 388 species. Spp. nov.: (1) Odontophorus atrifrons, p. 127; (2) Myiobis assimilis, p. 144; (3) Ochthœca jesupi, p. 151; (4) Ochthoca olivacea, p. 152; (5) Attila parvirostris, p. 153; (6) Attila rufipectus, p. 153; (7) Grallaria bangsi, p. 159; (8) Hylophilus brunneus, p. 171.

622. Beyer's 'The Avifauna of Louisiana.' <Auk, XVII, pp. 392-393, Oct., 1900.

Review of George E. Beyer's annotated list of the Birds of Louisiana (Proc. Louisiana Soc. Naturalists, 1897-1899 [1900]. Birds, pp. 1-45 of reprint).

623. Burns's 'A Monograph of the Flicker.' <Auk, XVII, pp. 393-394, Oct., 1900. Review of Frank L. Burns's paper in Wilson Bulletin, April, 1900, pp. 1-82.

624. John Macoun's 'Catalogue of Canadian Birds.' <Auk, XVII, pp. 394-395, Oct., 1900.

Review of Part I of this work (8vo, Ottawa, 1900).

625. Proceedings of the Delaware Valley Ornithological Club. <Auk, XVII, p. 395, Oct., 1900.

Synopsis of No. III, for the years 1898 and 1899 (1900).

626. Economic Ornithology.<Auk, XVII, pp. 396-399, Oct., 1900.

Review of various circulars and reports by Dr. T. S. Palmer, issued by the U. S. Department of Agriculture.

627. The Birds of Celebes and Neighboring Islands. <Science, N. S., XII, pp. 223225, Aug. 10, 1900.

Review of A. B. Meyer and L. W. Wigglesworth's work of this title (2 vols., 4to, Berlin, 1898).

628. Meyer and Wigglesworth's 'Birds of Celebes.' <Auk, XVII, 1900, pp. 399-401.

(See supra, No. 627.)

1901.

629. Joseph Grinnell's 'Birds of the Kotzebue Sound Region.' <Auk, XVIII, pp. 119-120, Jan., 1901.

Review of the paper (Pacific Coast Avifauna, No. 1, pp. 1-80, and map). 
630. Sharpe's 'Hand-List of the Genera and Species of Birds. $<A u k$, XVIII, pp. 120-121, Jan., 1901.

Review of Vol. II. (See supra, No. 598.)

631. Dubois's 'Synopsis Avium.' <Auk, XVIII, pp. 121-122, Jan., 1901.

Review of fascicles II-IV. (See supra, No. 599.)

632. G. E. Shelley's 'Birds of Africa.' < Auk, XVIII, p. 122, Jan., 1901.

Review of Vols. I and II (4to, London, 1896 and 1900).

633. Republication of Descriptions of New Species and Subspecies of North American Birds. No. 2. <Auk, XVIII, pp. 172-179, April, 1901.

Includes the forms described in 1900. (See supra, No. 583.)

634. Richard M. Barrington's 'The Migration of Birds at Irish Light Stations.' < Auk, XVIII, pp. 205-206, April, 1901.

Review of the work (8vo, London and Dublin, 1900).

635. Gätke's 'Heligoland.' Second German Edition.<Auk, XVIII, pp. 206-207, April, 1901.

Brief notice.

636. Collett on the Skull and Auricular Openings in North European Owls. $<A u k$, XVIII, p. 207, April, 1901.

Brief notice of Dr. R. W. Shufeldt's English translation in Journal of Morphology, XVII, 1900, pp. 119-176, pll. xv-xx.

637. Merriam and Preble on the Summer Birds of Western Maryland. $<A u k$, XVIII, p. 208, April, 1901.

Review of their paper in the Alleghany County Report of Maryland Geol. Surv., 1900, pp. 291-307, Nov. 1900 .

638. Loomis on California Water Birds. <Auk, XVIII, pp. 208-209, April, 1901.

Review of No. V, of this series of papers (Proc. California Acad. Sci., 3d ser., II, pp. 349363 , Nov. 24,1900$)$.

639. Eaton's 'Birds of Western New York.' <Auk, XVIII, pp. 212-213, April, 1901.

Review of Elon Howard Eaton's paper in Proc. Rochester Acad. Sci., IV, 1901, pp. 1-64.

640. The Question of the Generic Name Gavia. <Auk, XVIII, pp. 270-271, April, 1901.

S. G. Gmelin's use of the name Gavia is merely a citation from Brisson, without nomenclatural significance, contrary to the opinion of Dr. Anton Reichenow.

641. Norton on Birds from Labrador. <Auk, XVIII, p. 277, April, 1901.

Review of Arthur H. Norton's paper in Proc. Portland Soc. Nat. Hist., II, 1901, pp. 139158 , pl. ii.

642. Howe and Allen's 'Birds of Massachusetts.' <Auk, XVIII, p. 278, July, 1901.

Review of R. H. Howe and G. M. Allen's work (8vo, Cambridge, Mass., 1901).

643. R. M. Strong's 'Quantitative Study of Variation in the Smaller North American Shrikes.' <Auk, XVIII, pp. 283-284, July, 1901.

Review of his paper of this title in Amer. Nat., XXXV, April, 1901, pp. 271-298. 
644. Stone 'On Moult and Alleged Color-change in Birds.' <Auk, XVIII, p. 284, July, 1901.

Review of Witmer Stone's paper in The Ibis, April, 1901, pp. 177-183.

645. Selous's 'Bird Watching.' < Auk, XVIII, pp. 408-409, Oct., 1901.

Review of Edmund Selous's work (8vo, London, 1901).

646. The Woodpeckers. By Fannie Hardy Eckstorm. <The Nation, LXXII, No. 1867, April 11, 1901. Also Auk, XVIII, p. 210, April, 1901.

Review of the work (square 12mo, Boston, 1901).

1902.

647. 'Der Gesang der Vögel, seine anatomischen und biologischen Grundlagen.' < Science, N. S., XV, pp. 98-99, Jan., 1902.

Review of Dr. Valentin Häcker's work of this title (gr. 8vo, Jena, 1900).

648. The Birds of North and Middle America. <Science, N. S., XV, pp. 225-226, Feb. 7, 1902.

Review of Part I of R. Ridgway's work of this title (Bulletin 50, U. S. National Museum).

649. Ridgway's 'Birds of North and Middle America.' <Auk, XIX, pp. 97-102, Jan., 1902.

Review of Part I. (See supra, No. 648.)

650. Scott on the Song of Baltimore Orioles in Captivity. <Auk, XIX, pp. 102-104, Jan., 1902.

Review of 'Data on Bird Songs,' by W. E. D. Scott (Science, N. S., XIV, pp. 522-526, Oct. 4, 1901).

651. Sharpe's 'Hand-List of the Genera and Species of Birds.' <Auk, XIX, pp. 105106, Jan., 1902.

Review of Vol. III. (See supra, Nos. 598 and 630.)

652. Stark's 'Birds of South Africa.' < Auk, XIX, pp. 106-107, Jan., 1902.

Review of Vol. II. (See supra, No. 611.)

653. Osgood's Contributions to the Natural History of the Queen Charlotte Islands and the Cook Inlet Region of Alaska. <Auk, XIX, pp. 108-110, Jan., 1902.

Review of W. H. Osgood's paper (North Amer. Fauna, No. 21, Sept. 1901).

654. Verrill's 'The Story of the Cahow.' <Auk, XIX, pp. 110-111, Jan., 1902.

Review of A. E. Verrill's paper in Pop. Sci. Monthly, LX, Nov., 1901, pp. 22-30.

655. Bonhote's 'On the Evolution of Pattern in Feathers.' <Auk, XIX, pp. 112114, Jan., 1902.

Review of J. L. Bonhote's speculative essay (Proc. Zool. Soc. London, 1901, pp. 316-326).

656. Proceedings of the Nebraska Ornithologists' Union. $<A u k$, XIX, p. 215, April, 1902.

Review of the Proceedings of the second annual meeting, held in Omaha, Jan. 12, 1901. 
657. The American and European Herring Gulls. <Auk, XIX, pp. 283-284, April, 1902.

Not separable even as subspecies.

658. The name of the Zenaida Dove.<Auk, XIX, pp. 286-287, April, 1902.

The Columba meridionalis Latham, 1801, is not the Zenaida zenaida Bonaparte, as claimed by Forbes and Robinson (Bull. Liverpool Mus., I, 1898, p. 36).

659. Campbell's Nests and Eggs of Australian Birds. <Auk, XIX, pp. 301-302, July, 1902. 1900)

Review of Archibald James Campbell's work of this title (2 vols., Royal 8vo, Melbourn,

660. Woodcock's Birds of Oregon. <Auk, XIX, pp. 302-303, July, 1902.

Review of A. R. Woodcock's 'Annotated List,' etc. (Bull. 68, Oregon Agric. Exper. Station, Corvallis, Oregon, Jan., 1902).

661. Proceedings of the Delaware Valley Ornithological Club. $<A u k$, XIX, pp. 303-304, July, 1902.

Review of Cassinia for 1901.

662. Perkins and Howe's 'Preliminary List of the Birds of Vermont.' $<A u k$, XIX, pp. 304-306, July, 1902.

Review of two papers by, respectively, George H. Perkins and Reginald Heber Howe, the latter a critique of the former.

663. Upland Game Birds. <Amer. Nat., XXXVI, p. 575, Sept., 1902.

Review of Edwyn Sandys and T. S. Van Dyke's work of this title (8vo, New York and London, 1902).

664. 'Upland Game Birds.' <Auk, XIX, pp. 306-307, July, 1902.

Review of the work. (See supra, No. 663.)

665. A. S. Packard's 'Lamarck, His Life and Work.' <A uk, XIX, p. 306, July, 1902. Brief review of the work (8vo, London and New York, 1901).

666. Richmond's 'List of Generic Terms Proposed for Birds during 1890-1900.' < Auk, XIX, pp. 307-308, July, 1902.

Review of Dr. Charles W. Richmond's paper of this title (Proc. U. S. Nat. Mus., XXIV, No. 1267, May, 1902, pp. 663-729).

667. Oberholser's Review of the Horned Larks. $<A u k$, XIX, pp. 308-309, July, 1902 .

Review of H. C. Oberholser's 'A Review of the Larks of the genus Otocoris' (Proc. U. S. Nat. Mus., XXIV, No. 1271, June, 1902, pp. 801-884).

668. Ogilvie-Grant on Recently Described American Gallinæ.<Auk, XIX, pp. 309-311, July, 1902.

Critical notice of W. R. Ogilvie-Grant's paper entitled 'Remarks on the Species of American Gallinæ,' etc. (The Ibis,' pp. 233-245, April, 1902).

669. Grinnell's 'Check-List of California Birds.' <Auk, XIX, pp. 405-407, Oct., 1902.

Critical review of Joseph Grinnell's paper of this title (Pacific Avifauna, No. 3, 1902, pp. 1-92, 2 col. maps). 
670. Berlepsch and Hartert on the Birds of the Orinoco Region. $<A u k$, XIX, pp. 407-408, Oct., 1902.

Review of their paper in Novitates Zoologicæ, IX, 1902, pp. 1-134.

671. Dubois's 'Synopsis Avium.' <Auk, XIX, p. 409, Oct., 1902.

Review of Parts V-X, completing Vol. I, 1899-1902. (See supra, Nos. 599, 631.)

672. Chapman on Birds from Alaska. <Auk, XIX, p. 414, Oct., 1902.

Review of F. M. Chapman's paper (Bull. Amer. Mus. Nat. Hist., XVI, pp. 231-247, Aug., 1902).

673. So-called Species and Subspecies. <Science, N. S., XVI, pp. 383-386, Sept. 5, 1902.

674. In re Meleagris sylvestris Vieillot. <Auk, XIX, pp. 419-420, Oct., 1902.

Comment on C. Davies Sherborn's letter to The Auk under this title, with reference to previous editorial criticism of Mr. Ogilvie-Grant (Auk, XIX, p. 311).

1903.

675. The A. O. U. Check-List - Its History and its Future. $<A u k$, XX, pp. 1-9, Jan., 1903.

676. Vernacular Names of Birds. <Auk, XX, pp. 70-73, Jan., 1903.

Mainly in reference to the use of the hyphen in compound names, with other comment in relation to Dr. Edwin Doran's article in the same issue of The Auk (pp. 38-42) proposing certain rules for the construction of vernacular names of birds.

677. Ridgway's 'Birds of North and Middle America.'<Auk, XIX, pp. 73-76, Jan., 1903.

Review of Part II. (See supra, Nos. 648 and 649.)

678. Mrs. Florence Merriam Bailey's 'Handbook of Birds of the Western United States.' <Auk, XX, pp. 76-78, Jan., 1903.

Review of the work (12mo, Boston and New York, 1902).

679. Brewster's 'Birds of the Cape Region of Lower California.' $<A u k, \mathrm{XX}, \mathrm{pp} .78-$ 80, Jan., 1903.

Review of the work (Bull. Mus. Comp. Zoöl., XLI, Sept., 1902, pp. 1-244, and map).

680. [H. W.] Henshaw's 'Birds of the Hawaiian Islands.' $<A u k, \mathrm{XX}$, pp. 80-81, Jan., 1903.

Review of the work (8vo, Honolulu, 1902).

681. Snodgrass and Heller on the Birds of Clipperton and Cocos Islands. $<A u k$, XX, pp. 81-82, Jan., 1903.

Review of their paper in Proc. Washington Acad. Sci., IV, Sept., 1902, pp. 501-520.

682. Strong on the Development of Color in Feathers. $<A u k, \mathrm{XX}$, pp. 86-88, Jan., 1903.

Review of Dr. R. M. Strong's 'The Development of Color in the Definitive Feather' (Bull. Mus. Comp. Zoöl., XL, 1902, pp. 146-186, pll. i-ix).

683. Note on Psittacula modesta Cabanis. <Auk, XX, p. 213, April, 1903.

$P$ sittacula modesta and $P$. m. sclateri are considered as both entitled to recognition. 
684. Note on Sylvia carulea Wilson. <Auk, XX, pp. 216-218, April, 1903.

Sylvia cærulea Wilson not preoccupied by Sylvia cærulea Latham, the latter being not the name of a new species but $=$ Motacilla cærulea Linn. transfcrred to the genus Sylvia. The principle involved is discussed at length.

685. Ornithological Magazines.<Auk, XX, pp. 219-226, April, 1903.

Reviews of The Condor, Bird-Lore, and Wilson Bulletin for the year 1902.

686. Pycraft on 'The Significance of the Condition of Young Birds at Birth.' $<A u k$, XX, pp. 227-228, April, 1903.

Review of W. P. Pycraft's paper on this subject (Pop. Sci. Monthly, LXII, Dec., 1902, pp. 108-116).

687. "Some Suggestions." <Auk, XX, pp. 234-235, April, 1903.

Comment on a letter to the editors of The Auk, under the above title, suggesting its restricting the output of faunal lists in favor of articles of more popular interest.

688. [The American Museum of Natural History.]<Auk, XX, pp. 246-248, April, 1903.

Account of the 'Bird Group' exhibits in the Museum.

689. The California Meeting of the American Ornithologists' Union. $<A u k, \mathrm{XX}$, pp. 299-302, July, 1903.

Held in San Francisco, May 15-16, 1903.

690. Winkenwerder on the Migration of Birds. $<A u k$, pp. 311-313, July, 1903.

Review of H. A. Winkenwerder's 'The Migration of Birds, with special Reference to Nocturnal Flights' (Bull. Wisconsin Nat. Hist. Soc., II, No. 4, Oct. 1902, pp. 177-263).

691. North American Water-Fowl.<Auk, XX, pp. 313-314, July, 1903.

Review of 'The Water-Fowl Family,' by L. C. Sanford, L. B. Bishop and T. S. Van Dyke. (8vo, New York, 1903. American Sportsman's Library series).

692. The 'New' Edition of Nuttall. <Auk, XX, p. 314, July, 1903.

Review of Montague Chamberlain's, 'A Popular Handbook of the Birds of the United States and Canada. By Thomas Nuttall.' Criticism of the work.

693. Scott's 'The Story of a Bird Lover.' <Auk, XX, pp. 315-316, July, 1903.

Review of W. E. D. Scott's autobiographical work thus entitled (8vo, New York, 1903).

694. Snow's Catalogue of the Birds of Kansas. $<A u k$, XX, p. 317, July, 1903.

Review of the fif th edition of Professor Francis H. Snow's Catalogue of Kansas Birds (reprinted from Trans. Kansas Acad. Sci., XVIII).

695. Bangs on New Subspecies of American Birds. <Auk, XX, p. 320, July, 1903.

Brief mention of eight papers by Outram Bangs, in Proc. New England Zoöl. Club, Vols. III and IV, 1902-1903.

696. North's 'Nests and Eggs of Australian Birds.' <Auk, XX, pp. 321-322, July, 1903.

Notice of the second edition of A. J. North's work of this title, issued in three parts, 1901-1903.

697. Seth-Smith's Handbook of Parrakeets. $<A u k$, XX, pp. 322-323, July, 1903, and XXI, p. 96, 1904.

Review of David Seth-Smith's 'Parrakeets, a Handbook to the imported Species' (Svo. London, 1903). 
698. J. Macoun's Catalogue of Canadian Birds. <Auk, XX, p. 441, Oct., 1903.

Review of Part II. (See supra, No. 624.)

699. Dresser's 'A Manual of Palæarctic Birds.' < Auk, XX, pp. 441-442, Oct., 1903. Review of H. E. Dresser's work thus entitled (8vo, London, Pt. I, 1902, Pt. II, 1903).

700. Huntington's 'Our Feathered Game.'<Auk, XX, p. 443, Oct., 1903.

Review of Dwight W. Huntington's book on North American Game Birds (crown 8vo, New York, 1903)

701. Degen on the 'Perennial Moult' in the Australian Crow. $<A u k, \mathrm{XX}$, pp. 444446, Oct., 1903.

Review of 'Ecdysis, as Morphological Evidence of the Tetradactyle Feathering of the Bird's Forelimb, based on the Perennial Moult in Gymnorhina tibicen, by Edward Degen (Trans. Zool. Soc. London, XVI, pt. viii, May, 1903, pp. 347-412, pll. xxxvi-xxxviii).

702. Weed's Bibliography of Economic Ornithology. <Auk, XX, p. 446, Oct., 1903.

A brief notice of Clarence M. Weed's 'A Partial Bibliography of the Economic Relations of some North American Birds.' (Tech. Bull. No. 5, New Hampshire College Agric. Exper. Station.)

703. Stone on Birds of Southern New Mexico and Western Texas. $<A u k, \mathrm{XX}, \mathrm{p}$. 447, Oct., 1903.

Review of a paper by Witmer Stone and James A. G. Rehn in Proc. Acad. Nat. Sci. Philadelphia, 1903, pp. 16-34.

704. Bonhote's List of Birds Collected in the Bahamas. <Auk, XX, pp. 447-448, Oct., 1903.

Review of J. Lewis Bonhote's paper in The Ibis, July, 1903, pp. 273-312.

705. Ornithological Magazines: 'The Osprey.' <Auk, XX, pp. 451-452, Oct., 1903. Review of Vol. VI of this magazine.

706. F. M. Chapman's 'The Economic Value of Birds to the State.' $<A u k, \mathrm{XX}$, p. 453 , Oct., 1903.

Review of the work (4to, 1903, State of New York Forest, Fish and Game Commission).

707. The A. O. U. Model Law. <Condor, V, pp. 157-158, Nov., 1903.

Defense of the provision for ornithological collecting.

1904.

708. Mason A. Walton's 'A Hermit's Wild Friends.' < Auk, XXI, pp. 87-90, Jan., 1904.

Extended criticism of the work (8vo, Boston, 1893).

709. Fisher's 'Birds of Laysan.' <Auk, XXI, p. 90, Jan., 1904.

Review of Walter K. Fisher's paper on 'Birds of Laysan and the Leeward Islands, Hawaiian Group' (U. S. Fish Comm. Bulletin for 1903, pp. 4-15).

710. Jones's 'The Birds of Ohio.' <Auk, XXI, pp. 90-91, Jan., 1904.

Review of Lynds Jones's work of this title (Ohio State Acad. Sci., Special Papers, No. 6, 1903, pp. 141, with map). 
711. Sharpe's 'Hand List of the Genera and Species of Birds.' $<A u k$, XXI, pp. 92-93, Jan., 1904.

Review of Volume IV, 1903. (See supra, Nos. 598, 630 and 651.)

712. Ridgway on New American Birds. $<A u k$, XXI, p. 93, Jan., 1904.

Brief notice of two important papers (in Proc. Biol. Soc. Washington, XVI, pp. 105-113. $167-170)$.

713. Ernest Hartert's 'Der Vögel der Paläarktischen Fauna.' <Auk, XXI, pp. 9495, Jan., 1904.

Review of Heft I of this important work (large 8vo, Berlin, 1903).

714. The Avicultural Magazine.<Auk, XXI, pp. 95-96, Jan., 1904.

Review of Vol. I, new series.

715. Coues's 'Key to North American Birds.' Fifth Edition. $<A u k$, XXI, pp. 292-296, April, 1904.

Review of this posthumous edition of a celebrated work (2 vols., roy. 8 vo, Boston, 1903).

716. F. M. Chapman's 'Color Key to North American Birds.' $<A u k$, XXI, pp. 296-297, April, 1904.

Review of the work (8vo, New York, 1903).

717. Mrs. Wheelock's 'Birds of California.' <Auk, XXI, pp. 299-300, April, 1904. Review of the work (sm. 8vo, Chicago, 1904).

718. Kumlien and Hollister's 'The Birds of Wisconsin.' <Auk, XXI, pp. 301-302, April, 1904.

Review of the work (Bull. Wisconsin Nat. Hist. Soc., III, 1903).

719. Silloway's 'The Birds of Fergus County, Montana.' $<A u k$, XXI, pp. 302-303, April, 1904.

Review of P. M. Silloway's paper forming Bull. No. 1, Fergus County High School, Lewistown, Mont., 1903.

720. Oberholser's 'Review of the Wrens of the Genus Troglodytes.' <Auk, XXI, pp. 303-304, April, 1904.

Review of H. C. Oberholser's paper of this title (Proc. U. S. Nat. Mus., XXVII, No. 1354, Feb., 1904, pp. 197-210, and map).

721. Oberholser on the American Great Horned Owls. $<A u k$, XXI, pp. 304-305, April, 1904.

Review of H. C. Oberholser's paper 'A Revision of the American Great Horned Owls' (Proc. U. S. Nat. Mus., XXVII, No. 1352, pp. 177-192, Feb., 1904).

722. Snodgrass and Heller on the Birds of the Galapagos Archipelago. $<A u k$, XXI, pp. 305-306, April, 1904.

Review of paper by Robert Evans Snodgrass and Edmund Heller (Proc. Washington Acad. Sci., V, 1904).

723. Shufeldt on the Osteology of the Halcyones and Limicolæ. $<A u k$, XXI, p. 306 , April, 1904.

Review of two papers by R. W. Shufeldt (Amer. Nat., XXXVII, pp. 697-724; Ann. Carnegie Mus., II, pp. 15-70, pl. i and 27 text figs.). 
724. Evans's 'Turner on Birds.' <Auk, XXI, pp. 306-307, April, 1904.

Review of A. H. Evans's annotated translation of this early work (8vo, Cambridge, 1903).

725. Recent Papers on Economic Ornithology. <Auk, XXI, pp. 307-308, April, 1904.

Review of papers by Sylvester D. Judd, Edward Howe Forbush, and H. P. Attwater.

726. Summary of Game Laws for 1903. <Auk, XXI, pp. 308-309, April, 1904.

Based on papers by Henry Oldys, T. S. Palmer, and R. W. Williams, Jr. (Dept. Agric. Washingtou).

727. The case of Megalestris vs. Catharacta.<Auk, XXI, pp. 345-348, July, 1904. Catharacta Brïnich preoccupied by Catarractes Brisson; extended comment on the case.

728. Black-capped Petrel in New Hampshire. <Auk, XXI, p. 383, pl. xxii, July, 1904.

729. W. T. Hornaday's 'The American Natural History.' < Auk, XXI, pp. 394-395, July, 1904.

Review of the work (8vo, New York, 1904).

730. Boardman's 'The Naturalist of the St. Croix.' <Auk, XXI, pp. 397-398, July, 1904. 1903).

Review of Samuel Lane Boardman's 'Memoir of George A. Boardman' (8vo, Bangor,

731. Pearson's 'Three Summers among the Birds of Russian Lapland.' <Auk, XXI, pp. 398-399, July, 1904.

Review of the work (8vo, London, 1904).

732. Swarth on the 'Birds of the Huachuca Mountains, Arizona.' <Auk, XXI, pp. 401-402, July, 1904.

Review of Henry S. Swarth's paper of this title, forming Pacific Avifauna, No. 4, 1904 (70 pp.).

733. Nelson's 'Revision of the American Mainland Species of Myiarchus.' <Auk, XXI, pp. 403-404, July, 1904.

Review of E. W. Nelson's paper of this title in Proc. Biol. Soc. Washington, XVII, 1904, pp. 151-160.

734. Code of Botanical Nomenclature. <Auk, XXI, pp. 404-405, July, 1904.

Reviewed and compared with the A. O. U. Code (Bull. Torrey Botan. Club, XXXI, No. 5, May, 1904.)

735. Bird Groups in the American Museum of Natural History. $<A u k$, XXI, p. 408 , July; 1904.

736. So-called Nature Books. <Auk, XX்I, p. 409, July, 1904.

Comment on the works of William J. Long and Mason A. Walton.

737. The International Catalogue of Scientific Literature. $<A u k$, XXI, pp. 494-501, Oct., 1904.

A critical review of the section "Zoology" in the first annual issue. 
738. Cooke's 'Some New Facts about Bird Migration.' <Auk, XXI, pp. 501-503, Oct., 1904.

Review of Wells W. Cooke's paper of this title in Yearbook of U. S. Dept. Agric. for 1903, pp. $371-386$.

739. G. M. Allen's 'The Birds of New Hampshire.' < Auk, XXI, pp. 503-505, Oct., 1904.

Review of Glover M. Allen's paper in Proc. Manchester (N. H.) I.nst. Arts and Sciences, IV, pt. I, 1902 (1903), pp. 23-222.

740. Hartert's 'Die Vögel der Paläarktischen Fauna.' <Auk, XXI, pp. 505-506, Oct., 1904.

Review of Part II. (See supra, No. 713.)

741. Kirtland's Warbler. <Auk, XXI, pp. 506-507, Oct., 1904.

Review of papers on this species by Charles C. Adams and Norman A. Wood.

742. Forbush on the Destruction of Birds by the Elements. $<A u k$, XXI, pp. 507509, Oct., 1904.

Review of E. H. Forbush's 'Special Report' on this subject (Fifty-first Ann. Rep. Massachusetts State Board of Agric.).

1905.

743. Cooke's 'Distribution and Migration of North American Warblers.' $<A u k$, XXII, pp. 91-92, Jan., 1905.

Review of Wells W. Cooke's paper of this title in Bulletin No. 18, Division of Biological Survey, U. S. Dept. Agric., 1904.

744. Osgood on Birds of Alaska.<Auk, XXII, pp. 92-93, Jan., 1905.

Review of W. H. Osgood's 'A Biological Reconnaissance of the Base of the Alaska Peninsula' (North Amer. Fauna, No. 24, 1904).

745. Preliminary Review of the Birds of Nebraska. $<A u k$, XXII, pp. 94-95, Jan., 1905.

Review of a brochure of this title by Lawrence Bruner, Rohert $\mathrm{H}$. Walcott, Myron $\mathrm{H}$. Swenk (8vo, Omaha, no date).

746. Scott on the Inheritance of Song in Passerine Birds. <Auk, XII, pp. 95-96, Jan., 1905. 1904 .

Review of two papers on this subject by W. E. D. Scott, in Science, Vols. XIX and XX,

747. Scott's Ornithology of Patagonia. <Auk, XXII, pp. 96-97, Jan., 1905.

Review of W. E. D. Scott's Ornithology of Patagonia, Part I, Rheidæ-Sphenicidæ (Vol. II of the Reports of Princeton University Expeditions to Patagonia, pp. 1-112, 1896-1899).

748. Bryan's 'A Monograph of Marcus Island.'<Auk, XXII, pp. 98-99, Jan., 1905.

Review of Wm. Alanson Bryan's paper in Occas. Papers of the Bernice Pauahi 11us., II, No. 1, 1903.

749. J. Macoun's 'Catalogue of Canadian Birds.' <Auk, XXII, pp. 99-100, Jan., 1905.

Review of Part III (8vo, Ottawa, 1904). 
750. Riley on the Birds of Barbuda and Antigua. <Auk, XXII, p. 101, Jan., 1905.

Review of J. H. Riley's 'Catalogue of a Collection of Birds from Barbuda and Antigua, British West Indies.' (Smithsonian Misc. Coll., quart. issue, XLVII, 1904, pp. 277-291).

751. Dubois's 'Synopsis Avium.' <Auk, XXII, p. 102, Jan., 1905.

Review of fasc. xiii-xvi, completing Alphonse Dubois's work of this title (roy. 8vo, Bruxelles, 1899-1902). (See supra, Nos. 599, 631, and 671.)

752. Report on the Birds Collected in Northeastern Siberia by the Jesup North Pacific Expedition, with Field Notes by the Collector. <Bull. Amer. Mus. Nat. Hist., XXI, 1905, pp. 219-257, July 24, 1905.

An annotated list of 127 species. Spp. nov.: (1) Alauda buxtoni, p. 247; (2) Anthus anadyrensis, p. 254 .

753. Madarázs's 'An Extraordinary Discovery in Ornithology.' $<A u k$, XXII, pp. 102-103, Jan., 1905.

Review of Julius V. Madarász's paper of this title (Ann. Mus. Nat. Hist. Hungarici, II, 1904, pp. 396-398).

754. Shalow on Arctic Birds. <Auk, XXII, pp. 103-104, Jan., 1905.

Review of Dr. H. Shalow's 'Die Vögel der Arktis' in Fauna Arctica, Vol. IV, pt. 1, pp. 81-288, 1904 .

755. [Bird Groups in the American Museum of Natural History.]<Auk, XXII, pp. 107-109, Jan., 1905.

756. [Work of the A. O. U. Committee for Bird Protection.] $<A u k$, XXII, pp. 110112, Jan., 1905.

757. The Loggerhead Shrike in Connecticut in Winter. $<A u k$, XXII, p. 211, April, 1905.

758. Ridgway's 'The Birds of North and Middle America.' <Auk, XXII, pp. 219222, April, 1905.

Review of Part III.

759. Richmond on Birds described by Pallas in 1764. <Auk, XXII, pp. 222-223, April, 1905.

Review of Dr. Charles W. Richmond's "Notes on the Birds described by Pallas in the 'Adumbratiuncula' of Vroeg's Catalogue." (Smithsonian Misc. Coll., quart. issue, XLVII, 1905, pp. 342-347).

760. Harvie-Brown and Macpherson's 'A Fauna of the Northwest Highlands and Skye.' <Auk, XXII, p. 223, April, 1905.

Review of the work (sm. 4to, Edinburgh, 1904).

761. Hagmann's Concordance of Brazilian Birds described by Spix, Wied, Burmeister, and Pelzeln. <Auk, XXII, p. 226, April, 1905.

Review of Dr. G. Hagmann's paper in Boletim do Museu Goeldi, IV, 1904.

762. Raine on the Eggs of the Solitary Sandpiper. $<A u k$, XXII, pp. 100-101, Jan., 1905.

Summary of Walter Raine's paper on the 'Discovery of the Eggs of the Solitary Sandpiper' (Ottawa Nat., XVIII, pp. 135-138). 
763. Shufeldt on the Families and Higher Groups of Birds. <Auk, XXII, pp. 227228, April, 1905.

Review of R. W. Shufeldt's 'An Arrangement of the Families and Higher Groups of Birds ' (Amer. Nat., XXXVIII, 1904, pp. 833-857).

764. Shelley's 'Birds of Africa.' < Auk, XXII, pp. 228-229, April, 1905.

Review of Vol. IV, pt. 1 (London, 1905). (See supra, No. 632.)

765. Report of the Chief of the Biological Survey (Dr. C. Hart Merriam) for the Year ending June 30, 1904. <Auk, XXII, pp. 230-232, April, 1905.

Review of the Report (in Yearbook Dept. Agric. for 1904).

766. [Founding of the National Association of Audubon Societies.] $<A u k$, XXII, p. 232, April, 1905.

767. Townsend's 'The Birds of Essex County, Massachusetts.' <Auk, XXII, pp. 322-323, July, 1905.

Review of Dr. C. W. Townsend's work of this title (Mem. Nuttall Orn. Club, No. III, 1905).

768. Job's 'Wild Wings.' <Auk, XXII, pp. 324-325, July: 1905.

Review of the work (8vo, Boston and New York, 1905).

769. Sharpe on the Birds of the Antarctic Regions. <Auk, XXII, p. 325, July, 1905.

Review of Dr. R. B. Sharpe's Report on the Birds of the 'Southern Cross' Expedition (8vo, London, British Museum, 1904).

770. Butterfield on Bird Migration. <Auk, XXII, pp. 325-328, July, 1905.

Review of W. Ruskin Butterfield's 'Remarks upon Theories in regard to the Migration of Birds' (in Novitates Zool., XII, pp. 15-20, 1905).

771. Nelson on the Names of Certain North American Birds. $<A u k$, XXII, pp. 330331, July, 1905.

Review of two papers by E. W. Nelson in Proc. Biol. Soc. Washington, XVIII, 1905.

772. The Status of certain Swainsonian Genera of Birds. $<A u k$, XXII, pp. 400-407, Oct., 1905.

Discussion of the status of the genera Xiphorhynchus, Vermivora, Tiaris, and Ammodramus, first published incidentally in a paper preceding by a few weeks their formal publication with designation of a type species for each.

773. Stephens's 'Life Areas of California.' <Auk, XXII, pp. 424-246, Oct., 1905.

Review and synopsis of Frank Stephens's paper of this title (Trans. San Diego, California, Soc. Nat. Hist., I, No. 1, 1905).

774. Chapman on the Life History of the American Flamingo. $<A u k$, XXII, p. 426 , Oct., 1905.

Review of F. M. Chapman's paper in Bull. Amer. Mus. Nat. Hist., XXI, 1905, pp. 53-77, with 15 text figs.

775. Hartert's 'Die Vögel der Paläarktischen Fauna.' <Auk, XXII, pp. 428-429, Oct., 1905.

Review of Heft III. (See supra, Nos. 713, 740.) 
776. Clark on the Amount of Difference that should characterize Species and Subspecies. <Auk, XXII, pp. 429-434, Oct., 1905.

Review of Hubert Lyman Clark's 'The Limits of Difference in Specific and Subspecific Distinctions' (in Fifth Ann. Rep. Michigan Acad. Sci., 1903), discussing at length his six "fundamental rules."

777. Oberholser on the Nomenclature of Certain Genera of Birds. <Auk, XXII, pp. 436-437, Oct., 1905.

Review of H. C. Oberholser's paper entitled Notes on the Nomenclature of Certain Genera of Birds' (in Smithsonian Misc. Coll., quart. issue, XLVIII, 1905).

778. Forbush on the Decrease of Birds and Means for their Protection. $<A u k$, XXII, pp. 437-438, Oct., 1905.

Review of E. H. Forbush's 'Special Report' on this subject in 52d Ann. Rep. Massachusetts State Board of Agric., 1905.

779. Supplementary Notes on Birds Collected in the Santa Marta District, Colombia, by Herbert H. Smith, with Descriptions of Nests and Eggs. $<$ Bull. Amer. Mus. Nat. Hist., XXI, pp. 275-295, Oct. 4, 1905.

Additions and corrections, pp. 275-278; descriptions of nests and eggs, 42 species, pp. 279-295.

1906.

780. The Name of the Western Sandpiper. <Auk, XXIII, pp. 97-98, Jan., 1906.

Ereunetes occidentalis Lawrence (1864) should give place to Ereunetes mauri Gundlach 1856.

781. Stejneger's 'The Birds of the Genus Cinslus and their geographical Distribution.' <Auk, XXIII, pp. 111-112, Jan., 1906.

Review of Dr. L. Stejneger's paper of this title (in Smithsonian Misc. Coll., quart. issue, XLVIII, 1905).

782. Clark's 'Birds of the Southern Lesser Antilles.' <Auk, XXIII, pp. 113-114, Jan., 1906.

Review of Austin E. Clark's paper of this title (in Proc. Boston Soc. Nat. Hist., XXXII, No. 7,1905$)$.

783. Beebe's 'Two Bird Lovers in Mexico.' <Auk, XXIII, p. 115, Jan., 1906.

Review of C. William Beebe's book of this title (8vo, Boston and New York, 1905).

784. Hartzsch's Birds of Iceland.<Auk, XXIII, pp. 115-116, Jan., 1906.

Review of Bernhard Hantzsch's 'Beitrag zur Kenntniss der Vogelwelt Islands' (8vo, Berlin, 1905).

785. Csörgey's Ornithological Fragments from the Manuscripts of Johann Salamon von Petényi. <Auk, XXIII, pp. 116-117, Jan., 1906.

Review of the work (8vo, Gera-Untermhaus, 1905).

786. Harvie-Brown's 'Travels of a Naturalist in Northern Europe.' <Auk, XXIII, pp. 117-118, Jan., 1906.

Review of J. A. Harvie-Brown's work of this tille (2 vols., 8vo, London, 1905).

787. Economic Ornithology. <Auk, XXIII, pp. 119-120, Jan., 1906.

Review of three papers by Vernon Bailey, S. D. Judd, and W. L. McAtee (Bull. Biol. Survey, Nos. 21-23, 1905). 
788. Subgenera and Other Matters. $<A u k$, XXIII, pp. 122-125, Jan., 1906.

Anent Dr. Ernst Hartert's protest against certain editorial criticisms of Heft III of his 'Die Vögel der Paläarktischen Fauna,' in The Auk, Vol. XXII, p. 428.

789. [First Annual Meeting of the National Association of Audubon Societies.] $<A u k$, XXIII, pp. 126-128, Jan., 1906.

General account of the proceedings.

790. Thayer and Bangs on Birds from Panama. <Auk, XXIII, pp. 234-235, April, 1906.

Review of four papers on Panama birds, chiefly by Outram Bangs.

791. Verrill on Birds of Dominica. <Auk, XXIII, pp. 235-237, April, 1906.

Review of A. Hyatt Verrill's paper on the 'Avifauna of Dominica' (privately printed, unpaged, and without date).

792. Whitaker's 'The Birds of Tunisia.' <Auk, XXIII, pp. 238-240, April, 1906.

Review of J. I. S. Whitaker's work of this title ( 2 vols., large 8 vo, London, 1905).

793. Ralfe's 'The Birds of the Isle of Man.' <Auk, XXIII, p. 240, April, 1990.

Review of P. G. Ralfe's book of this title (8vo, Edinburgh, 1905).

794. Economic Ornithology. <Auk, XXIII, pp. 241-242, April, 1906.

Review of papers by McAtee, Judd, Palmer, and others, published by U. S. Dept. of Agric.

795. Buturlin's 'The Breeding-grounds of the Rosy Gull.' <Auk, XXIII, pp. 348349, July, 1906.

Review of S. A. Buturlin's paper of this title in The Ibis, 1906, pp. 131-139, 333-337.

796. Clarke's 'Birds of the South Orkney Islands.' $<A u k$, XXIII, pp. 350-351, July, 1906.

Review of Wm. Eagle Clarke's paper of this title in The Ibis, Jan., 1906, pp. 145-187, pll. iii-xiii.

797. Menegaux and Hellmayr on the Passeres Tracheophones of the Paris Museum. $<A u k$, XXIII, pp. 351-363, July, 1906.

Review of three papers by these authors published in 1905 and 1906 in Bulletins and Memoirs of three different French scientific societies. See further on this matter, Auk, XXIII, pp. 480-483, Oct., 1906.

798. 'An Eccological Survey in Northern Michigan.' <Auk, XXIII, p. 354, July, 1906.

Review of a Report prepared under the direction of Prof. Chas. C. Adams, University of Michigan (8vo, Lansing, Mich., 1906).

799. Brewster's 'The Birds of the Cambridge Region.' $<A u k$, XXIII, pp. 466-470, Oct., 1906.

Review of William Brewster's work of this title (Mem. Nuttall Orn. Club, No. IV, 1906).

800. Report on the Immigration of Birds in England and Wales in the Spring of 1905. <Auk, XXIII, p. 472, Oct., 1906.

Review of the Report, by a Committee of the British Ornithologists' Club (Bull. Britis.' Orn., Club, XVII, 1906). 
801. 'A Hand-List of the Birds of the Philippine Islands.' <Auk, XXIII, pp. 472473, Oct., 1906. Rev)

802. New Names for North American Birds.<Auk, XXIII, pp. 474-475, Oct., 1906.

Review of three papers on this subject by H. C. Oberholser and of one by Outram Banqs.

803. Palmer on Federal Game Protection. <Auk, XXIII, pp. 475-477, Oct., 1906.

Review of Dr. T. S. Palmer's 'Federal Game Protection - A Five Years' Retrospect' (in Yearbook of U. S. Dept. of Agric., 1905, pp. 541-562).

1907.

804. The Rio Grande Seedeater, its Status and Technical History. $<A u k$, XXIV, pp. 26-30, Jan., 1907.

Sporophila morelleti sharpei (Lawrence) shown to be a well-marked subspecies.

805. Beebe's 'The Bird.' <Auk, XXIV, pp. 112-113, Jan., 1907.

Review of C. William Beebe's work of this title (large 8vo, New York, 1906).

806. Hellmayr on Spix's Types of Brazilian Birds. <Auk, XXIV, pp. 113-114, Jan., 1907.

Review of C. E. Hellmayr's 'Revision der Spix'schen Typen Brasilianische Vögel' (Abhandl. der K. B. Akad. Wiss., XXII, pp. 563-726, May, 1906).

807. Lönnberg on the Birds of South Georgia. <Auk, XXIV, p. 115, Jan., 1907.

Review of Einar Lönnberg's paper on birds in 'Contributions to the Fauna of South Georgia' (8vo, = Vet. Akad. Handl., XI, No. 5, 1906).

808. Harvie-Brown's 'A Fauna of the Tay Basin.' <Auk, XXIV, pp. 115-117, Jan., 1907.

Review of J. A. Harvie-Brown's book of this title (sm. 4to, Edinburgh, 1906, pp. 1-102, pll. $\mathrm{i}-\mathrm{xii}$ and 7 text figs.).

809. Chapman's 'The Warblers of North America.'<Auk, XXIV, pp. 227-229, April, 1907.

Review of F. M. Chapman's work of this title (8vo, New York, 1907).

810. Alphéraky's 'The Geese of Europe and Asia.' <Auk, XXIV, pp. 229-230, April, 1907.

Review of Sergius Alphéraky's work (4to, London, 1905).

811. Schiebel's 'Phylogeny of the Species of Lanius.' <Auk, XXIV, p. 230, April, 1907.

Review of Dr. P. G. Schiebel's 'Die Phylogenese der Lanius Arten' (in Journ. f. Orn., 1900, pp. 1-77, 161-219, pll. 8, 7 colored).

812. Hellmayr on the Types of Little-known Neotropical Birds. $<A u k$, XXIV, p. 231, April, 1907.

Review of C. E. Hellmayr's paper in Novitates Zool., XIII, July, 1906, pp. 305-352. 
813. Cooke's the 'Distribution and Migration of North American Ducks, Geese and Swans.' <Auk, XXIV, pp. 232-233, April, 1907.

Review of Wells W. Cooke's paper (Bull. Biol. Surv., No. 26).

814. Forbush's 'Useful Birds and their Protection.' <Auk, XXIV, pp. 234-235, April, 1907.

Review of E. H. Forbush's work thus entitled (8vo, no date, Massachusetts State Board of Agriculture).

815. Dionne's Birds of the Province of Quebec. <Auk, XXIV, p. 236, April, 1907.

Review of C. E. Dionne's 'Les Oiseaux de la Province de Québec' (8vo, Quebec, 1906).

816. Cole on Birds from Yucatan. <Auk, XXIV, p. 237, April, 1907.

Review of Dr. Leon J. Cole's 'Aves' in 'Vertebrata from Yucatan' (Bull. Mus. Comp. Zoöl., L, No. 5, 1906, pp. 100-159. Birds, pp. 109-146).

817. Salvin and Godman's 'Biologia Centrali-Americana, Aves.' $<A u k, \mathrm{XXIV}, \mathrm{pp}$. 350-352, July, 1907.

Review of the work (4 vols., 4to, 1879-1905).

818. Proceedings of the Fourth International Ornithological Congress. $<A u k$, XXIV, pp. 352-354, July, 1907.

Review of the volume (Ornis, Vol. XIV, 1907).

819. Newton's 'Ootheca Wolleyana.' <Auk, XXIV, pp. 354-355, July, 1907.

Review of Part IV, completing the work (London, 8vo, 1905).

820. Mershon's 'The Passenger Pigeon.' <Auk, XXIV, pp. 355-357, July, 1907.

Review of W. B. Mershon's work of this title (8vo, New York, 1907).

821. Forbes's 'An Ornithological Cross-section of Illinois in Autumn.' $<A u k$, XXIV, pp. 358-359, July, 1907.

Review of Prof. S. A. Forbes's paper of this title (Bull. Illinois State Laboratory of Nat. Hist., VII, pp. 305-335, April, 1907).

822. Berlepsch 'On the Genus Elonia.' <Auk, XXIV, p. 360, July, 1907.

Review of paper in Proc. IVth Internat. Orn. Congress, 1905 (1906, pp. 372-448).

823. Hartert's 'Die Vögel der Paläarctischen Fauna.'<Auk, XXIV, p. 362, July, 1907.

Review of Heft IV, March, 1907.

824. Woodruff's 'The Birds of the Chicago Area.' <Auk, XXIV, p. 363, July, 1907.

Review of Frank M. Woodruff's paper of this title (Chicago Acad. Nat. Sci., Bull. No. VI of the Nat. Hist. Survey, 1907).

825. Fleming on Migrations of Brünnich's Murre. <Auk, XXIV, p. 364, July, 1907.

Review of J. H. Fleming's 'The Unusual Migration of Brünnich's Murre (Uria lomvia) in Eastern North America,' in Proc. IVth Internat. Orn. Congress, 1905 (1906), pp. 528-543, 2 maps.

826. The Types of North American Genera of Birds. <Bull. Amer. Mus. Nat. Hist., XXIII, pp. 279-284, April 5, 1907.

On the basis of the principle of elimination in opposition to the "first species rule." The introductory matter deals with the 'first reviser' and 'Brissonian genera.' All of the original species of each genus are listed, and their subsequent generic disposition shown. 
827. The Balophus bicolor-atricristatus Group. \&Bull. Amer. Mus. Nat. Hist., XXIII, pp. 467-481, June 12, 1907.

A study in geographic variation, etc. Mr. Ridgway's conclusion that B. bicolor and B. atricristatus freely hybridize in portions of Texas is confirmed.

828. Birds of North and Middle America.<Amer. Nat., LXI, pp. 672-673, Oct., 1907.

Brief notice of R. Ridgway's work of this title, Parts I-IV.

829. Ridgway's 'The Birds of North and Middle America.' <Auk, XXIV, pp. 450451, Oct., 1907.

Review of Part IV, 1907.

830. Townsend and Allen's 'Birds of Labrador.' <Auk, XXIV, pp. 451-452, Oct., 1907.

Review of Dr. Charles W. Townsend and Glover M. Allen's paper of this title (Proc. Boston Soc. Nat. Hist., XXXIII, No. 7, 1907, pp. 277-428, with map.)

831. Townsend's 'Along the Labrador Coast.' $<A u k$, XXIV, pp. 452-453, Oct., 1907.

Review of Dr, Charles W. Townsend's work of this title (8vo, Boston, no date, [1907]).

832. Clark on New Birds from Eastern Asia and the Aleutian Islands. $<A u k$, XXIV, p. 453, Oct., 1907.

Review of paper by Austin H. Clark in Proc. U. S. Nat. Mus., XXXII, pp. 467-475, 1907.

833. Clarke 'On the Birds of the Weddell and adjacent Seas.' $<A u k$, XXIV, pp. 454-455, 1907.

Review of William Eagle Clarke's report on the ornithological results of the Scottish National Antarctic Expedition (Ibis, 1907, pp. 325-349 and map.)

834. Goeldi's 'Album de Aves Amazonicas.' < Auk, XXIV, p. 455, Oct., 1907.

Review of Dr. Emilio A. Goeldi's work of this title (4to, 1900-1906).

835. Herman's 'The Protection of Birds in Hungary.' <Auk, XXIV, pp. 456-457, Oct., 1907.

Review of Otto Herman's Report to the Hungarian Government (8vo, Budapest, 1907).

836. Anderson's 'The Birds of Iowa.'<Auk, XXIV, pp. 458-459, Oct., 1907.

Review of Rudolph M. Anderson's paper of this title (Proc. Davenport Acad. Sci., XI, pp. 125-417, March, 1907).

837. [The Seventh International Congress of Zoölogy.] $<A u k$, XXIV, pp. 462-466, Oct., 1907.

Short account of the Boston Congress (August 19-24, 1907), with a transcript of the new Article 30 of the International Code of Zoölogical Nomenclature adopted at this Congress, here first published.

838. A List of the Genera and Subgenera of North American Birds, with their Types, according to Article 30 of the International Code of Zoölogical Nomenclature.<Bull. Amer. Mus. Nat. Hist., XXIV, pp. 1-50, Dec. 26. 1907.

Historical résumé, pp. 3-12, containing comment on 'Article 30,' and on 'G. R. Gray as a First Reviser.' The determination of types by Rule 30 gives practically the same results as by elimination, the two methods giving the same type in 192 out of 197 cases where the type depends on 'subsequent designation.' 
1908

839. The Generic Names Mycteria and Tantalus of Linnæus, 1758, <Auk, XXV, pp. 37-38, Jan., 1908.

Tantalus, a synonym of Mycteria, is replaced by Jabiru Hellmayr, 1906.

840. Widmann's 'Birds of Missouri.' < Auk, XXV, pp. 89-90, Jan., 1908.

Review of Otto Widmann's 'A Preliminary Catalogue of the Birds of Missouri' (Trans. Acad. Sci. St. Louis, XVII, No. 1, pp. 1-288, Nov., 1907).

841. Jones on 'The Development of Nestling Feathers.' <Auk, XXV, p. 90, Jan., 1908.

Review of Dr. Lynds Jones's paper of this title (Laboratory Bull. No. 13, Oberlin College, Ohio, 1907).

842. Beebe on Geographic Variation in Birds. <Auk, XXV, pp. 90-93, Jan., 1908.

Review of C. William Beebe's 'Geographic Variation in Birds with especial reference to the Effects of Humidity' (in Zoologica, I, No. 1, 1907, pp. 1-41, with 5 half-tone pll.).

843. Braislin's Birds of Long Island, New York.<Auk, XXV, p. 93, Jan., 1908.

Review of Dr. Wm. C. Braislin's 'A List of the Birds of Long Island, New York' (in Abst. Proc. Linnæan Soc. New York for 1907, pp. 31-123).

844. Finley's 'American Birds.' <Auk, XXV, pp. 93-94, Jan., 1908.

Review of William Lovell Finley's work of this title (8vo, New York, 1907).

845. Ihering's Birds of Brazil. <Auk, XXV, pp. 94-95, Jan., 1908.

Review of Dr. Hermann von Ihering's 'As Aves do Brazil' (8vo, São Paulo, Brazil, 1907).

846. Beal on 'Birds as Conservators of the Forest,' and on 'Birds of California in Relation to the Fruit Industry.' <Auk, XXV, pp. 95-97, Jan., 1908.

Review of two papers on these subjects by Prof. F. E. L. Beal, the first in Rep. New York Forest, Fish and Game Comm., 1902-03; the other in Bull. Biolog. Survey, No. 30, 1907).

847. Riddle's 'A Study of Fundamental Bars in Feathers.' <Auk, XXV, p. 98, Jan., 1908.

Review of Oscar Riddle's paper of this title (Biol. Bull., XII, No. 3, 1907, pp. 165-174).

848. Riddle on the Cause of Production of 'Down' and other Down-like Structures in the Plumages of Birds. <Amer. Nat., XLII, pp. 693-696, Oct., 1908.

Review of paper by Oscar Riddle (in Biolog. Bull., XIV, pp. 163-176, Feb., 1908).

849. Hopkins on the Bony Semicircular Canals of Birds. $<A u k$, XXV, pp. 98-99, Jan., 1908.

Review of Miss May Agnes Hopkins's paper on this subject (Biol. Bull., XI, No. 5, 1906, pp. 253-265).

850. A Twenty-five Year Index to 'The Auk' and 'Nuttall Bulletin.' $<A u k, \mathrm{XXV}$, pp. 99-100, Jan., 1908.

Review of Dr. J. Dwight's 'Index,' etc., as above (8vo, Amer. Orn. Union, 1907).

8.51. Annual Report of the National Association of Audubon Societies for 1907. $<A u k$, XXV, pp. 101-102, Jan., 1908.

Review of President William Dutcher's Report as above (Bird-Lore, IX, pp. 285-372). 
852. The Case of Hortulanus Vieillot. <Auk, XXV, pp. 223-224, April, 1908. If recognized (under the rule of priority) would supercede Zonotrichia Swainson, 1832.

853. Shaw's 'The China or Denny Pheasant in Oregon.' $<A u k, \mathrm{XXV}, \mathrm{pp} .241-242$, April, 1908.

Review of William T. Shaw's illustrated brochure of this title (Philadelphia, 1908).

854. Giglioli's 'Avifauna Italica.' <Auk, XXV, p. 242, April, 1908.

Review of Prof. E. H. Giglioli's work of this title (8vo, Firenze, 1907).

855. Bonhote's 'Birds of Britain.' <Auk, XXV, p. 243, April, 1908.

Review of J. Lewis Bonhote's illustrated work of this title (8vo, London, 1907).

856. 'British Birds.' <Auk, XXV, pp. 243-244, Jan., 1908.

Review of Vol. I of the magazine British Birds, London, 1907.

857. Godman's 'Monograph of the Petrels.' <Auk, XXV, p. 244, April, 1908.

Review of Part I of F. Du Cane Godman's 'Monograph' of the Tubinares' (4to, London, Dec., 1907).

858. The Work of the Biological Survey. $<A u k$, XXV, pp. 246-247, April, 1908.

Review of 'Report on Work of the Biological Survey,' by James Wilson, Secretary U. S . Department of Agriculture (Senate Doc. No. 132, 60th Congress, 1st Session, 1907).

859. The Case of Strix vs. Aluco. <Auk, XXV, pp. 288-291, July, 1908.

Strix shown to belong to the Strix aluco group, while Aluco is the proper name for the Barn Owls.

860. Columbina vs. Chœmepelia. <Auk, XXV, pp. 301-306, July, 1908.

Columbina Spix (1825) has priority over Chæmepelia Swainson (1827), and under Rule 30 of the International Code is tenable in place of Chæmepelia.

861. Walter on Bird Migration. <Auk, XXV, pp. 329-333, July, 1908.

Review of 'Theories of Bird Migration' by Hubert Eugene Walter (in School Science and Mathematics, April-May, 1908), with extended comment on the general subject of bird migration.

862. 'Cassinia.' <Auk, XXV, p. 335, July, 1908.

Review of 'Cassinia, a Bird Annual,' for 1907.

863. Beebe on the Seasonal Changes of Color in Birds. $<A u k$, XXV, pp. 335-336, July, 1908.

Review of C. William Beebe's 'Preliminary Report on an Investigation of the Seasonal Changes of Color in Birds' (Amer. Nat., XLII, pp. 34-38, Jan., 1908).

864. Contributions to Philippine Ornithology. $<A u k$, XXV, p. 336, July, 1908.

Brief mention of 14 papers on Philippine birds by several different authors, in Philippine Journ. Science, II, No. 5, Oct., 1907.

865. Menegaux on the Birds of the French Antarctic Expedition. $<A u k$, XXV, p. 337, July, 1908.

Review of Dr. A. Menegaux's report on the Birds of the Expédition Antarctique Française, 1903-1905, under Dr. Jean Charcot (4to, no date). 
866. Reichenow on Sea-Birds. <Auk, XXV, pp. 337-338, July, 1908.

Review of Dr. Anton Reichenow's 'Vögel des Weltmeers: Die Meeresvögel'der'ostlichen Erdhälfte,' in Deutsch Südpolar-Expedition 1901-1903, Vol. X, Zoologie I, Pp. 435-467, with 6 pll. and map.

867. Godman's 'Monograph of the Petrels.' <Auk, XXV, pp. 338-339, July, 1908.

Review of Part II. Puffinus godmani, nom. nov., for "Puffinus bailloni" tentatively employed in this work for the Madeiran Shearwater.

868. Howard's 'The British Warblers.' <Auk, XXV, pp. 339-440, July, 1908.

Review of Parts I and II of H. Eliot Howard's work of this title (4to, London, Feb., 1907, and March, 1908).

869. Stone on 'Methods of Recording and Utilizing Bird-Migration Data.' $<A u k$, XXV, pp. 488-490, Oct., 1908.

Review of Witmer Stone's paper of this title (Proc. Acad. Nat. Sci. Philadelphia, 1908, pp. 128-156).

870. Forbes's Statistical Study of the Mid-Summer Bird Life of Illinois. $<A u k$, XXV, pp. 491-492, Oct., 1908.

Review, of Prof. S. A. Forbes's 'The Mid-Summer Bird Life of Illinois: A Statistical Study’ (in Amer. Nat., XLII, August, 1908, pp. 505-519).

871. Membership Conditions in the A. O. U. <Auk, XXV, pp. 495-496, Oct., 1908.

Comment (jointly with F. M. Chapman) in reply to a letter to The Auk under this title by John Lewis Childs.

872. Riddle on the Genesis of Fault-bars and the Cause of Alternation of Light and Dark Bars in Feathers. < Amer. Nat., XLII, pp. 550-552, August, 1908.

Review of Oscar Riddle's paper of this title (Biol. Bull., XIV, No. 6, May, 1908, pp. 328370 , pll. xii-xv).

873. Pennant's 'Indian Zoology.' <Bull. Amer. Mus. Nat. Hist., XXIV, pp. 111116, Feb. 7, 1908).

Collation of the several editions, and list of species in the 1769 edition, with relation to the names employed for them by subsequent authors. Otus bakkamoena p. 3, pl. ii, 1769, is the first use of Otus in a generic sense (monotypic).

1909.

874. An American's Views of Bird Migration.<British Birds, III, pp. 12-19, June, 1909.

Written by request of the Editor of British Birds.

875. Chapman's 'Camps and Cruises of an Ornithologist.' $<A u k$, XXVI, pp. 89-90, Jan., 1909.

Review of F. M. Chapman's work of this title (8vo, New York, 1908).

876. Preble on the Birds of the Athabaska-Mackenzie Region. $<A u k$, XXVI, pp. 90-92, Jan., 1909.

Review of Edward A. Preble's 'A Biological Investigation of the Athabaska-Mackenzie Region' (North Amer. Fauna, No. 27, Oct., 1908). 
877. MacFarlane on the Birds of Northwestern Canada. <Auk, XXVI, pp. 92-93, Jan., 1909.

Review of Roderick MacFarlane's 'Notes on the Mammals and Birds of Northern Canada,' in Charlcs Mair's 'Through the Mackenzie Basin,' etc. (8vo, Toronto, 1908).

878. Knight's 'The Birds of Maine.' <Auk, XXVI, pp. 93-95, Jan., 1909.

Review of Ora Willis Knight's work of this title (8vo, Bangor, 1908).

879. Godman's 'Monograph of the Petrels.' <Auk, XXVI, p. 95, Jan., 1909.

Review of Part III.

880. Gadow's 'Through Southern Mexico.' <Auk, XXVI, p. 95, Jan., 1909.

Review of Dr. Hans Gadow's work of this title (8vo, London, 1908).

881. Report on the Migration of Summer Residents in England and Wales, in the spring of 1907. <Auk, XXVI, p. 96, Jan., 1909.

Review of the report (= Bull. British Orn. Club, XX, 1908).

882. The Heath Hen. <Auk, XXVI, pp. 96-97, Jan., 1909.

Review of Dr. George W. Field's report of the 'Eastern Pinnated Grouse or Heath Hen, in 42d Ann. Rep. Massachusetts Commissioners on Fisheries and Game for 1907.

883. Taverner and Swales on the Birds of Point Pelee, Ontario. $<A u k$, XXVI, pp 98-99, Jan., 1909.

Review of 'The Birds of Point Pelee,' by P. A. Taverner and B. H. Swales (in Wilson Bulletin, Vols. XIX and XX, 1907-08).

884. Bryan on the Birds of Molokai.<Auk, XXVI, pp. 99-100, Jan., 1909.

Review of Wm. Alanson Bryan's 'Some Birds of Molokai.' (Occas. Papers, B. P. Bishop Mus., IV, No. 2, 1908, pp. 43-86).

885. Annual Report of the National Association of Audubon Societies. $<A u k$, XXVI, pp. 100-101, Jan., 1909.

Review of President William Dutcher's Annual Report for 1908 (in Bird-Lore, X, 1908 pp. 277-329).

886. Report of the Chief of the Bureau of Biological Survey for 1908. $<A u k$, XXVI, pp. 101-102, Jan., 1909.

Review of Dr. C. Hart Merriam's Report (in Ann. Reports of U. S. Dept. Agriculture. 1908).

887. Richmond's List of Generic Terms proposed for Birds during 1901-1905. <Auk, XXVI, pp. 102-104, Jan., 1909.

Review of Dr. Charles W. Richmond's paper in Proc. U. S. Nat. Mus., XXXV, pp. 583655, Dec., 1908.

888. The Habitat Groups of North American Birds in the American Museum of Natural History. <Auk, XXVI, pp. 165-175, pll, i-iv, April, 1909.

Inception and history of the construction and installation of the Bird Groups in this Museum with special mention of the large 'Habitat Groups' with illustrations from photographs of the groups.

889. Grinnell's 'The Biota of the San Bernardino Mountains.' $<A u k$, XXVI, pp: 202-203, April, 1909.

Review of Joseph Grinnell's paper of this title (in University of California Publ., Zool., V, No. 1, 1908, pp. 1-170, pll. i-xxiv). 
890. Grinnell on Birds of Southeastern Alaska. <Auk, XXVI, pp. 203-204, April, 1909.

Review of 'Birds and Mammals of the 1907 Alexander Expedition to Southeastern Alaska' (University of California Publ., Zool., V, No. 2, 1909, pp. 171-264, ppl. xxv, xxvi, and 4 text figs.).

891. Grinnell on Birds Observed at Salton Sea. <Auk, XXVI, p. 204, April, 1909. Review of J. Grinnell's 'Birds of a Voyage on Salton Sea' (Condor, X, 1908, pp. 185-191).

892. Chapman on the Life-Histories of the Booby and Man-o'-War Bird. $<A u k$, XXVI, p. 205, April, 1909.

Review of F. M. Chapman's 'A Contribution to the Life-Histories' etc., as above (in Papers from the Tortugas Laboratory of the Carnegie Inst., Washington, II, 1908 [1909], pp. 139-151, pll. i-vi).

893. Count von Berlepsch on the Birds of Cayenne: $<A u k$, XXVI, pp. 207-208, April, 1909.

Review of Hans Graf von Berlepsch's paper 'On the Birds of Cayenne' (Novitates Zool., XV, 1908, pp. 103-164, 261-324).

894. 'Cassinia.' <Auk, XXVI, pp. 208-209, April, 1909.

Review of Cassinia, a Bird Manual, for 1908.

895. Stone's 'A Review of the Genus Piaya Lesson.' <Auk, XXVI, p. 209, April, 1909.

Review of Witmer Stone's paper of this title (Proc. Acad. Nat. Sci. Philadelphia, LX, Pt. 3, 1908, pp. 492-501).

896. Watson's 'The Behavior of Noddy and Sooty Terns.' <Auk, XXVI, pp. 209214, April, 1909.

Review of John B. Watson's paper of this title (in Papers from the Tortugas Laboratory of the Carnegie Inst., Washington, II, 1908 (1909), pp. 187-225, pll. i-xi), with, incidentally, a protest against the pedantic jargon of many recent works on psychology and ecology.

897. [The Roosevelt Expedition to Africa.]<Auk, XXVI, p. 220, April, 1909.

898. Jubilee Meeting of the British Ornithologists' Union. <Auk, XXVI, pp. 317319, July, 1909.

Based on the 'Jubilee Supplement' to The Ibis, 1909, Vol. II.

899. Thayer and Bangs on the Birds of Guadaloupe Island. <Auk, XXVI, pp. 319320, July, 1909.

Review of 'The Present State of the Ornis of Guadaloupe Island' by John E. Thayer and Outram Bangs (Condor, X, No. 3, 1908, pp. 101-106).

900. New North American Birds. <Auk, XXVI, pp. 321-322, July, 1909.

Review of three papers, respectively by E. W. Nelson, Thayer and Bangs, and J. Grinnell with comment on the status of Melospiza melodia gouldi Baird and M. m. saltonis Grinnell.

901. Widmann on 'The Summer Birds of Shaw's Garden.' <Auk, XXVI, p. 322, July, 1909.

Review of Otto Widmann's paper of this title in 20th Ann. Rep. Missouri Botanical Garden (pp. 41-80, col. pl.).

902. Godman's 'Monograph of the Petrels ' < Auk, XXVI, p. 323, July, 1909.

Brief notice of Part IV. 
903. Howard's 'The British Warblers.' <Auk, XXVI, pp. 323-326, July, 1909. Extended notice of Part III. (See supra, No. 868.)

904. Grinnell's 'A Bibliography of California Ornithology.' <Auk, XXVI, p. 326, July, 1909.

Review of Joseph Grinnell's paper of this title (Pacific Coast Avifauna, No. 5, 1909).

905. Dawson and Bowles's 'The Birds of Washington.' <Auk, XXVI, pp. 328-329, July, 1909.

Review of William Leon Dawson's work of this title (2 vols., 4to, Seattle, 1909).

906. [Scientific Ornithologists of America and Bird Protection.] $<A u k$, XXVI, p. 335-336, July, 1909.

The work of the American Ornithologists' Union, collectively and by individual members, for bird protection, in refutation of statements by Wm. T. Hornaday in Bull. New York Zool. Soc., June, 1909.

907. Cory's 'The Birds of Illinois and Wisconsin.' < Auk, XXVI, pp. 442-443, Oct., 1909.

Review of C. B. Cory's work of this title (Publ. Field Museum, Zool., Vol. IX, 1909).

908. Wright's 'Birds of the Boston Public Garden.' <Auk, XXVI, pp. 443-444, Oct., 1909.

Review of Horace W. Wright's book of this title (12mo, Boston and New York, 1909).

909. Hersey and Rockwell on the 'Birds of the Barr Lake District, Colorado.' < $A u k$, XXVI, p. 445, Oct., 1909.

Review of L. J. Hersey and R. B. Rockwell's paper of this title (Condor, XI, pp. 109-122, 1909).

910. Walcott's Analysis of the Bird Fauna of Nebraska. <Auk, XXVI, pp. 447-448, Oct., 1909.

Review of Robert H. Walcott's paper of this title (Proc. Nebraska Orn. Union, IV, Part 2, pp. 25-55, pll. i-vi).

1910.

911. Sharpe's Hand-List of Birds. <Auk, XXVII, pp. 93-95, Jan., 1910.

Review of the concluding volume (Vol. V) of R. Bowdler Sharpe's 'A Hand-List of the Genera and Species of Birds.' (See supra, Nos. 598, 630, 651, and 711.)

912. Sharpe's Hand-List of Birds. <Science, N. S., XXXI, No. 790, pp. 265-267, Feb. 18, 1910.

Review of R. Bowdler Sharpe's 'A Hand-List of the Genera and Species of Birds.'

913. Birds of New York.<Science, N. S., XXXII, No. 816, pp. 247-248, Aug. 19, 1910.

Review of Part I of Elon Howard Eaton's work of this title (4to, Albany, 1909).

914. Stone's 'Birds of New Jersey.' < Auk, XXVII, pp. 95-97, Jan., 1910.

Review of Witmer Stone's 'The Birds of New Jersey,' in Ann. Report of New Jersey State Museum for 1908 (1909).

915. G. M. Allen's List of the Birds of New England. <Auk, XXVII, p. 97, Jan., 1910. 
Review of 'Fauna of New England. II. List of Aves,' by Glover M. Allen (Occasional Papers, Boston Soc. Nat. Hist., Vol. VII).

916. Osgood's 'Biological Investigations in Alaska and Yukon Territory.' $<A u k$, XXVII, pp. 97-98, Jan., 1910.

Review of Wilfred H. Osgood's paper of this title (North Amer. Fauna, No. 30).

917. Seton on the Mammals and Birds of Manitoba. <Auk, XXVII, p. 98, Jan., 1910.

'Review of Ernest Thompson Seton's 'Fauna of Manitoba,' in British Association Handbook, Winnipeg, 1909 (12mo, pp. 47).

918. Job's 'The Sport of Bird Study.' <Auk, XXVII, p. 102, Jan., 1910.

Review of H. K. Job's book of this title (8vo, New York, 1908).

919. Report of the Chief of the Bureau of Biological Survey, 1909. $<A u k$, XXVII, pp. 104-106, Jan., 1910.

Review of the Annual Report of the Survey for 1909.

920. Macoun's 'Catalogue of Canadian Birds.' <Auk, XXVII, pp. 107-108, Jan., 1910.

Review of the second edition, published in 1909. (See supra, Nos. 624, 698, 749).

920a. The Bird Plume Bill. <Forest and Stream, Feb. 19, 1910.

921. Thayer on Concealing Coloration in Animals. <Auk, XXVII, pp. 222-225, April, 1910.

Review of Gerald H. Thayer's 'Concealing Coloration in the Animal Kingdom' (4to, New York, 1909 = Feb., 1910).

922. Reed and Wright on the Birds of Cayuga Lake Basin, New York. $<A u k$, XXVII, p. 226, April, 1910.

Review of 'The Vertebrates of the Cayuga Lake Basin, N. Y.,' by Hugh D. Reed and Albert W. Wright (in Proc. Amer. Philos. Soc., XLVIII, No. 193, 1909).

923. L. H. Miller on California Fossil Birds. <Auk, XXVII, pp. 228-230, April, 1910.

Review of three papers by Loye Holmes Miller (in The Condor, and Univ. California Publ., Geol., V, 1909).

924. Ticehurst's 'A History of the Birds of Kent.' <Auk, XXVII, pp. 230-232, April, 1910.

Review of the work (8vo, London, 1909).

925. J. Grinnell on New North American Birds.<Auk, XXVII, pp. 232-234, April, 1910.

Review of four papers by Joseph Grinnell, with critical comment (in Univ. California Publ., Zool., V).

926. Godman's 'A Monograph of the Petrels.' <Auk, XXVII, p. 350, July, 1910.

Review of F. Du Cane Godman's concluding Part of the 'Monograph,' with comment on the work as a whole (large 4to, 106 col. pll., London, 1907-1910).

927. Coward's 'The Vertebrate Fauna of Cheshire.' < Auk, XXVII, pp. 351-353, July, 1910.

A review of a noteworthy monograph of an English County (2 vols., 8vo, London, 1910). 
928. 'Our Search for a Wilderness.' <Auk, XXVII, pp. 353-354, July, 1910. 1910).

In Venezuela and British Guiana, by Mr. and Mrs. C. William Beebe (8vo, New York,

929. Festa's 'In Darien and in Ecuador.' < $A u k$, XXVII, p. 354, July, 1910.

Review of Dr. E. Festa's 'Nel Darien e nell' Ecuador' (8vo, Torino, 1909).

930. Clark on Birds Collected or Observed in the North Pacific Ocean and adjacent Seas. <Auk, XXVII, pp. 357-358, July, 1910.

Review of the paper (Proc. U.S. Nat. Mus., No. 1727, April 30, 1910).

931. The A. O. U. Check-List of North American Birds. Third Edition. $<A u k$, XXVII, pp. 466-472, Oct., 1910. See also ibid., XXVIII, p. 122.

A statistical and historical review of the third in comparison with previous editions of the A. O. U. Check-List. (8vo, pp. 430, New York, August, 1910.)

932. Wayne's 'Birds of South Carolina.' <Auk, XXVII, pp. 472-474, Oct., 1910.

Review of Arthur Trezevant Wayne's work of this title (8vo, Charleston Museum, 1910).

933. A Biography of William MacGillivray. <A uk, XXVII, pp. 474-476, Oct., 1910.

Review of William MacGillivray's 'Life of William MacGillivray,' the great Scottish ornithologist and professor of natural history at Aberdeen University (8vo, London, 1910).

934. Collation of Brisson's Genera of Birds with those of Linnæus. <Bull. Amer. Mus. Nat. Hist., XXVIII, pp. 317-335, Nov. 11, 1910.

\section{1.}

935. 'A Naturalist in the Bahamas.' Auk, XXVIII, p. 126, Jan., 1911.

A memorial volume, by Henry Fairfield Osborn, containing the collected papers and a biographical sketch of John I. Northrop (8vo, New York, 1910).

936. Cooke's 'Distribution and Migration of North American Shorebirds.' <Auk, XXVIII, pp. 126-128, Jan., 1911.

Review of Wells W. Cooke's paper of this title (Biological Survey Bull. No. 35).

937. Beck's 'Water Birds of the Vicinity of Point Pinos, California.' <Auk, XXVIII, pp. 128-129, Jan., 1911.

Review of Rollo Howard Beck's paper of this title (Proc. California Acad. Sci., ser. 4, III, 1910).

938. Townsend's 'A Labrador Spring.'<Auk, XXVIII, p. 129, Jan., 1911.

Review of Charles W. Townsend's book of this title (12mo, Boston, 1909).

939. Hartert on the Proper Names of Various Species of British Birds. $<A u k$, XXVIII, p. 130, Jan., 1911.

Notice of Ernst Hartert's 'Notes on [the nomenclature of] Various Species of British Birds' (British Birds, IV, 1910, pp. 129-136).

940. Gladstone's 'The Birds of Dumfriesshire.' <Auk, XXVIII, p. 131, Jan., 1911.

Review of Hugh S. Gladstone's 'The Birds of Dumfricsshire, a Contribution to the Fauna of the Solway Area' (8vo, London, 1909).

941. Gunning and Haagner's 'A Check-List of the Birds of South Africa.' <Auk, XXVIII, pp. 133-134, Jan., 1911.

Review, with technical comment (Ann. Transvaal Mus., II, July, 1910, suppl., 84 pp.). 
942. [Gregory M.] Mathews's "The Birds of Australia." <Auk, XXVIII, p. 135, Jan., 1911.

Review of Parts I and II (Roy. 4to, with text figs, and colored plates, London, 1910).

943. Swarth's 'Birds and Mammals of the 1909 Alexander Alaska Expedition.' $<A u k$, XXVIII, p. 277, April, 1911.

Review of Harry S. Swarth's paper of this title in Univ. of California Publ., Zoology, VII, No. 2, 1911).

944. Tracy's 'Significance of White Markings in Birds of the Order Passeriformes.' $<A u k$, XXVIII, pp. 278-279, April, 1911.

Summary of Henry Chester Tracy's paper of this title (Univ. California Publ., Zoology, II, No. 13, 1910).

945. The Arizona 'Passenger Pigeons.' < Science, N. S., XXXII, No. 841, pp. 217219, Feb. 10, 1911.

Critique of 'Notes on the Passenger Pigeon,' by W J McGee, in Science, N. S., XXXII, pp. 958-964, Dec. 30, 1910, in which he claimed Passenger Pigeons were seen by him in 1905 in the "Sierra Gila, seventy-five miles southwest of Yuma and near the Mexican boundary."

946. McGee's 'Notes on the Passenger Pigeon.' <Auk, XXVIII, p. 289, April, 1911.

Refers to the above-cited papers by McGee and Allen. (See supra, No. 945.)

947. Hellmayr's 'The Birds of the Rio Madeira.' < Auk, XXVIII, p. 376, July, 1911.

Review of C. E. Hellmayr's paper of this title, in Novitates Zool., XVII, Dec., 1910.

948. Menegaux on Birds of Ecuador. <Auk, XXVIII, p. 376, July, 1911.

Notice of A. Menegaux's 'Étude des Oiseaux de l'Équateur rapportés par le Dr. Rivet' (in Mission du service géograph. de l'Armée pour la mesure d'un Arc de Méridian equatorial en Amér. du Sud, 1899-1906, t. IX).

949. 'Feathers and Facts.' <Auk, XXVIII, pp. 377-378, July, 1911.

Review of 'Feathers and Facts: A Reply to the Feather-Trade,' etc., printed for the Royal Society for the Protection of Birds, and of other (then) recent brochures dealing with the same subject.

950. Mathews's Proposed Changes in the Nomenclature of Birds. <Auk, XXVIII, pp. 495-498, Oct., 1911.

Critical review of three papers by Gregory M. Mathews containing numerous proposed changes in the nomenclature of birds, in opposition (in many cases) to the International Code of Zoölogical Nomenclature.

951. Roosevelt's 'Revealing and Concealing Coloration in Birds and Mammals.' $<A u k$, XXVIII, pp. 472-480, Oct., 1911.

Review of Theodore Roosevelt's paper in Bull. Amer. Mus. Nat. Hist., XXX, pp. 119-231, Aug. 23, 1911, and incidental comment on the general topic.

1912.

952. Mathews's 'The Birds of Australia.' < Auk, XXIX, p. 124, Jan., 1912.

Review of Part 5 of this work, completing Vol. I, with critical comment on the nomen* clature adopted in the case of certain genera of Penguins, etc. (See supra, No. 942.)

953. [Mathews's Notes on Nomenclature.]<Auk, XXIX, Jan., 1912, pp. 133-135.

An editorial rejoinder to Gregory M. Mathews's paper of this title (ibid., pp. 131-133), with special reference to the genus (Colymbus Linné (1758) and Colymbus Brisson (1760). 
954. Columbina vs. Chœmepelia.<Science, N. S., XXXIII, No. 844, pp. 336-337, March 3, 1912.

Columbina griseola Spix designated as type of Columbina.

955. [Ridgway's] 'Birds of North and Middle America.' <Science, N. S., XXXV, No. 900, pp. 499-501, March 29, 1912.

Review of Part V, issued Nov. 29, 1911.

1913.

956. Scharff's 'Distribution and Origin of Life in America.' <Auk, XXX, pp. 283286, April, 1913.

Extended critical review of the work (8vo, New York, 1912).

1914.

957. Birds of New York. <Science, N. S., XL, No. 1036, p. 677, Nov. 6, 1914.

Review of Part 2 of Elon Howard Eaton's 'Birds of New York' (4to, Albany, 1914). (See supra, No. 912, for review of Part I.)

\section{5.}

958. Roosevelt's 'Through the Brazilian Wilderness.' <Amer. Mus. Journ., XV, pp. 64-65, Feb., 1915.

Short review of the work (8vo, New York, 1914).

959. 'The Auk' Index, 1901-1910<Auk, XXXII, p. 242, April, 1915.

Notice of the 'Ten Year Index' to The Auk (Vols. XVIII-XXXVII, 1901-1910).

Note.-The above list contains 966 titles, numbered as follows: 1-959, plus $9 a$, $318 a, 406 a, 475 a, 523 a, 621 a, 920 a$.

Genera, Species and Subspecies Described AS NEW or Renamed.

New Genera.

Palcospiza, Bull. U. S. Geol. and Geogr. Surv. Terr., IV, No. 2, May 3, 1878, p. 443, pl. i.

Myrmochanes, Bull. Amer. Mus. Nat. Hist., II, p. 95, March, 1889.

Rhopocichla, Bull. Amer. Mus. Nat. Hist., III, p. 199, Feb. 20, 1891. (Preoccupied by Rhopocichla Oates, 1889).

Porphyriornis, Bull. Amer. Mus. Nat. Hist., IV, p. 57, May 9, 1892.

New Species and Subspecies.

1875 .

Ammodramus caudacutus var. nelsoni, Proc. Boston Soc. Nat. Hist., XVII, March, 1875 , p. 293. 
1876.

Falcinellus ridgwayi, Bull. Mus. Comp. Zoöl., III, No. 15, July, 1876, p. 335.

Gallinula garmani, Bull. Mus. Comp. Zoöl., III, No. 15, July, 1876, p. 357.

1877.

Coccygus lindeni, Bull. Essex Inst., VIII, No. 8, 1876, p. 81, Feb., 1877.

1878.

Palcospiza bella, Bull. U. S. Geol. and Geogr. Surv. Terr., IV, No. 2, p. 443, pl. i, May 3, 1878.

1888 .

Ammodramus maritimus peninsulce, Auk, V, p. 284, July, 1888.

Ammodramus maritimus sennetti, Auk, V, p. 286, July, 1888.

Tityra nigriceps, Auk, V, p. 287, July, 1888.

1889.

Anabazanops immaculatus, Bull. Amer. Mus. Nat. Hist., II, p. 96, March 22, 1889.

Picolaptes obtectus, ibid., II, p. 94.

Myrmochanes hypoleucus, ibid., II, p. 95.

Carpophaga rusbyi, ibid., II, p. 95.

Phlogopsis notata, ibid., II, p. 97.

Scytalopus bolivianus, ibid., II, p. 96.

Empidonax bolivianus, ibid., II, p. 86.

Chiroxiphia pareola boliviana, ibid., II, p. 87.

Enicornis striata, ibid., II, p. 89.

Leptasthenura fuliginiceps boliviana, ibid., II, p. 91.

Synallaxis griseiventris, ibid., II, p. 91.

Cyclorhis flavipectus trinitatis, Bull. Amer. Mus. Nat. Hist., II, p. 131, June 17, 1889.

Thryothorus longipes, Bull. Amer. Mus. Nat. Hist., II, p. 138, June 28, 1889.

Thryothorus macrurus, ibid., II, p. 137.

Platyrhynchus bifasciatus, ibid., II, p. 141.

Platyrhynchus insularis, ibid., II, p. 143.

Euscarthmus ochropterus, ibid., II, p. 143.

Sublegatus virescens, ibid., II, p. 149.

Thamnophilus doliatus mexicanus, ibid., II, p. 151.

1890.

Icterus northropi, Auk, VII, p. 343, Oct., 1890; ibid., VIII, pl. i, colored.

1891.

Mimocichla verrillorum, Auk, VIII, p. 217, April, 1891.

Callista margarito, Bull. Amer. Mus. Nat. Hist., III, p. 351, Sept. 29, 1891.

Zonotrichia capensis costaricensis, ibid., III, p. 374. 
1892.

Ramphocxlus atrosericeus capitalis, Bull. Amer. Mus. Nat. Hist., IV, p. 51, April 6, 1892.

Lophotriccus substriatus, ibid., IV, p. 53, May 9, 1892.

Picumnus obsoletus, ibid., IV, p. 55.

Porphyriornis comeri, ibid., IV, p. 57.

1893.

Pygmornis chapadensis, Bull. Amer. Mus. Nat. Hist., V, p. 122, July 19, 1893.

Piaya cayana cabanisi, ibid., V, p. 136.

Buteo albicaudatus sennetti, ibid., V, p. 144.

1900.

Odontophorus atrifrons, Bull. Amer. Mus. Nat. Hist., XIII, p. 127, Aug. 25, 1900.

Myiobis assimilis, ibid., XIII, p. 144.

Ochthoeca jesupi, ibid., XIII, p. 151.

Ochthoca olivacea, ibid., XIII, p. 152.

Attila parvirostris, ibid., XIII, p. 153.

Attila rufipectus, ibid., XIII, p. 153.

Grallaria bangsi, ibid., XIII, p. 159.

Hylophilus brunneus, ibid., XIII, p. 171.

1905.

Alauda buxtoni, Bull. Amer. Mus. Nat. Hist., XXI, p. 247, July 24, 1905.

Anthus anadyrensis, ibid., XXI, p. 254.

1908.

Puffinus godmani, nom. nov. for "Puffinus bailloni" of Godman's "Monograph of the Petrels,' Auk, p. 338, July, 1908. 


\section{REPTILES.}

1868.

1. Catalogue of the Reptiles and Batrachians found in the Vicinity of Springfield, Mass., with notices of all other species known to inhabit the State. $<$ Proc. Boston Soc. Nat. Hist., XII, pp. 171-204, Dec., 1868.

Reptilia, 24 spp.; Amphibia, 21 spp.

1869.

2. [Appendix to the Catalogue of Reptiles and Batrachians of Massachusetts.] <Proc. Boston Soc. Nat. Hist., XII, pp. 248-250, Feb., 1869.

Notes on 7 species.

1870.

3. Notes on Massachusetts Reptiles and Batrachians. <Proc. Boston Soc. Nat. Hist., XIII, 1870, pp. 260-263, April, 1870.

Notes on 6 species, and a list of Reptiles and Batrachians found in the vicinity of New Bedford, Mass., on information furnished by Mr. R. C. Ingraham. Malacoclemmys palustris Agassiz new to the Massachusetts list.

1874.

4. Notes on the Natural History of Montana and Dakota. <Proc. Boston Soc. Nat. Hist., XVII, pp. 33-91, Nov., 1874.

IV. Report on the Reptiles, pp. 68-69. An annotated list of 9 species. V. Report on the Batrachians, p. 70. An annotated list of 4 species.

1908.

5. Ruthven's Variations and Genetic Relationships of the Garter-snakes. <Amer. Nat., XLII, pp. 552-559, August, 1908.

Review of A. G. Ruthven's paper (Bull. 61, U. S. Nat. Mus., 1908). 


\section{ZOÖGEOGRAPHY.}

1. On the Mammals and Winter Birds of East Florida..... and a Sketch of the Bird Faunæ of Eastern North America. <Bull. Mus. Comp. Zoöl., II, No. 3, April, 1871, pp. 161-450.

Part V. On the Geographical Distribution of the Birds of Eastern North America, with special reference to the Number and Circumscription of the Ornithological Faunæ, pp. 375425; List of Authorities, pp. 426-450.

"In accordance with the facts stated above respecting the mode of the distribution of animals and plants over the earth's surface, and the zoölogical and botanical laws of the differentiation and mutual relations of the different regions, the following primary natural history divisions may be recognized: I, an Arctic Realm;1 II, a North Temperate Realm; III, an American Tropical Realm; IV, an Indo-African Tropical Realm; V, a South American Temperate Realm; VI, an African Temperate Realm; VII, an Antarctic Realm; VIII, an Australian Realm" (p. 380).

For eastern North America are recognized the following seven faunæ: (1) Floridian, (2) Louisianian, (3) Carolinian, (4) Alleghanian, (5) Canadian, (6) Hudsonian, (7) American Arctic. Their boundaries and their characteristic species of birds are given (pp. 387-404), and they are further considered with reference to mammals and reptiles (pp. 404-406).

The species of North American birds are considered and tabulated with reference to their geographical ranges (pp. 407-418). General remarks on the distribution and migration of the birds of the Eastern Province (pp. 418-425). A Bibliography of ornithological works and papers, or "List of Authorities," relating to North America occupies pages 426-450, geographically arranged by States and countries, and numbering 346 titles - much the largest list of papers relating to North American ornithology that appeared prior to 1878 .

\section{8.}

2. The Geographical Distribution of the Mammalia, considered in relation to the principal Ontological Regions of the Earth, and the Laws that govern the Distribution of Animal Life. <Bull. U. S. Geol. and Geogr. Surv. Terr., IV, No. 2, pp. 313-337, May 3, 1878.

I. General considerations, with criticism of the life-regions proposed by Dr. P. L. Sclater and supported by Mr. Alfred R. Wallace, pp. 313-329; II. Mammalian Regions of the Globe, pp. 329-373; III. General Summary, pp. 373-377.

The primary divisions are essentially as laid down in 1871 (see above), except that a South African Temperate Realm is admitted, and Madagascar is recognized as an additional Realm, designated as the Lemurian Realm. Under these are defined regions of secondary and tertiary rank where such subdivisions seemed to be required.

1891.

3. Merriam's 'Results of a Biological Survey of the San Francisco Mountain Region and Desert of the Little Colorado, Arizona.' <Auk, VIII, pp. 95-98, Jan., 1891.

Review of Dr. C. Hart Merriam's paper of this title (N. Amer. Fauna, No. 3, Sept. 11, 1898), mainly with reference to the portion relating to 'Generalizations concerning the Distribution of Life in North America.'

1 Divisions I and II are essentially the same as Triurctic of Heilprin (1882), renamed Holarctic by Heilprin in 1883, by suggestion of Alfred Newton, and since commonly known as Holarctic by those who reject the Sclaterian system of zoögeographical divisions. Arctogæa of Huxley (1868) is more comprehensive. 
1892.

4. Merriam on the Life Areas of North America.<Auk, IX, pp. 377-382, Oct., 1892.

Synoptic review of Dr. C. Hart Merriam's 'The Geographic Distribution of Life in North America with special reference to the Mammalia' (Proc. Biol. Soc. Washington, VII, pp.1-64, and map, April, 1892).

5. The Geographical Distribution of North American Mammals. <Bull. Amer. Mus. Nat. Hist., IV, pp. 199-243, pll. v-viii (colored maps), Dec. 29, 1892.

Influences determining the Geographical Distribution of Life, pp. 199-203; Systematic Classification of Life Areas, pp. 203-206; Primary Life Regions, pp. 206-207 (same as in No. 2 supra); North Temperate Realm, pp. 207-211; The Sclaterian System, pp. 211-212; The Mammals of North America considered in relation to the North American Region and its Subdivisions, pp. 213-240; Tropical North America, pp. 240-243; Tabular Synopsis, p. 243.

\section{3.}

6. The Geographical Origin and Distribution of North American Birds, considered in relation to Faunal Areas of North America. $<A u k$, X, pp. 97-150, pll. iii, iv (colored maps), July, 1893.

I. The Geographical Origin and Distribution of North American Birds, pp. 98-117; II. The Faunal Subdivisions of North America, considered with reference to their Relationships, Classification and Nomenclature, pp. 117-150 (tabular synopsis, p. 150).

The classification adopted is essentially the same as that recognized in 1892 (see supra, No. 5).

7. The Faunal Position of Lower California. <Auk, X, pp. 306-307, July, 1893.

In reply to comment by Dr. Merriam under this title (l. c., pp. 305-306).

1905.

8. Report on the Mammals collected in Northeastern Siberia by the Jesup North Pacific Expedition. <Bull. Amer. Mus. Nat. Hist., XIX, pp. 101-184, March 31, 1903.

American affinities of certain East Siberian Mammals, pp. 182-184.

9. Stephens's 'Life Areas of California.' <Auk, XXII, pp. 424-426, Oct., 1905.

Synoptic summary of Frank Stephens's paper of this title (Trans. San Diego, California, Soc. Nat. Hist., I, No. 1, 1905, pp. 1-8 and map), with comment. 


\section{EVOLUTION. ${ }^{1}$}

1871

1. Mammals and Winter Birds of East Florida, etc. <Bull. Mus. Comp. Zoöl., II, No. 3, pp. 161-450, April, 1871.

Part III. On Individual and Geographical Variation among Birds, considered in respect to its bearing upon the Value of certain assumed Specific Characters, pp. 186-250.

Wide range of individual variation shown to occur in a considerable number of species, with extensive tables of measurements, pp. 186-226; correlation of variations in general size, size of bill, etc., and in coloration, with differences in climatic and geographic conditions, pp. 229-242; species, varieties, and geographical races, pp. 242-250. A presentation of facts, without discussion of any theories of evolution, which appeared later (see infra, No. 7).

1872.

2. Notes of an Ornithological Reconnaissance, etc. <Bull. Mus. Comp. Zoöl., III, pp. 113-118, July, 1872.

In the introduction the general subject of geographical variation is discussed and new facts presented.

3. Geographical Variation in Color among North American Mammals and Birds. <Proc. Boston Soc. Nat. Hist., XV, 156-159, Sept., 1872.

Abstract of a verbal communication, summarizing the general subject, with comment by other speakers.

4. Geographical Variation in North American Birds. <Proc. Boston Soc. Nat. Hist., XV, pp. 212-219, Dec., 1872.

A general résumé of the author's studies of the subject, to that date. (Republished in Amer. Nat., VIII, pp. 534-541, Sept., 1874).

1874.

5. Geographical Variation in Color in North American Squirrels. <Proc. Boston Soc. Nat. Hist., XVI, pp. 276-294, May, 1874.

The introductory matter (pp. 276-286) relates to this subject. See especially the footnote to pp. 277,278 , giving references, etc., to previous discussions of the general subject of geographical variation in mammals and birds by the author and others.

1876.

6. Geographical Variation among North American Mammals. <Bull. Geogr. and Geol. Surv. Terr., II, No. 4, July 1, 1876, pp. 309-344.

The correlation of size with geographical variation is formulated (p. 310) under the three propositions:

"(1) Maximum physical development of the individual is attained where the conditions of environment are most favorable to the life of the species...

${ }^{1}$ Exclusive of numerous incidental references in many general papers and reviews. 
"(2) The largest species of a group (genus, subfamily, or family, as the case may be) are found where the group to which they severally belong reaches its highest development, or where it has what may be termed its center of distribution....

"(3) The most 'typical' or most generalized representatives of a group are found also near its center of distribution, outlying forms being generally more or less 'aberrant' or specialized...."

\section{7.}

7. The Influence of Physical Conditions in the Genesis of Species. <Radical Review, I, No. 1, pp. 108-140, May, 1877. (Republished, by request, in the Ann. Report of the Smithsonian Institution for 1905 (1906), pp. 375-402).

" The doctrine of natural selection, or the survival of the fittest, has recently been brought forward as the key to this complex problem, and is upheld by a large class of enthusiastic adherents, who accept it as the full solution of the whole question. By others the conditions of environment are believed to be far more influential in effecting a certain class of modifications, at least, than the necessarily precarious influence of natural selection," etc.

The direct modif ying influence of environment as a factor in evolution is regarded as more potent than natural selection taken in the narrow sense of the "survival of the fittest."

1880.

8. Origin of the Instinct of Migration. <Bull. Nutt. Orn. Club, V, pp. 151-154, July, 1880.

1883.

9. Note on Exceptions to the Law of Increase in Size Northward among North American Birds. <Bull. Nutt. Orn. Club, VIII, pp. 80-82, April, 1883.

In certain genera of Oscines, for the most part tropical in distribution.

\section{5.}

10. Sexual Selection and the Nesting of Birds. <Auk, II, pp. 129-139, April, 1885.

In reference to Wallace's 'Theory of Birds' Nests' (Intellectual Observer, July, 1867), and Dixon's 'On the Protective Colour of Eggs' (in Seebohm's Hist. Brit. Birds, Introd., pp. xxxxvii).

1892.

11. [Variations in Vertebrated Animals.]<Amer. Nat., XXVI, pp. 87-89, Jan., 1892.

Abstract of a paper presented at the meeting of the American Society of Naturalists held in Philadelphia, Dec. 29-30, 1891, in a joint discussion of 'Definite $v s$. Fortuitous Variation.'

\section{3.}

12. Keeler on the 'Evolution of the Colors of North American Birds.' $<A u k, \mathrm{X}$, pp. 189-195, 377-380, April and Oct., 1893.

A review of Charles A. Keeler's work of this title (8vo, San Francisco, 1893), adverse to his theories.

13. Beddard's 'Animal Coloration.' < Auk, X, pp. 195-199, April, 1893.

A review of Frank E. Beddard's work of this title (8vo, Londou and New York, 1892), with approving comment of the author's attitude respecting "protective coloration," "warning colors," "sexual coloration," and "mimicry," for which he finds little in support of these popular theories. 
14. The Discrimination of Species and Subspecies. $<$ Science, N. S., V, pp. 877-879, June 4, 1897.

Apropos of Dr. C. H. Merriam's 'Suggestions for a New Method of Discriminating bebetween Species and Subspecies,' published in a preceding number of Science.

1898.

15. 'A Precise Criterion of Species.' <Science, N. S., VII, pp. 801-802, June 10, 1898.

A criticism of Davenport and Blankinship's paper of this title in Science for May 20, 1898 , on the quantitive study of variation in species.

1899.

16. Davenport's Statistical Methods.<Amer. Nat., XXXIII, pp. 974-975.

Criticism of 'Statistical Methods with special reference to Biological Variation' by C. B. Davenport (12mo, New York, 1899).

1902.

17. 'So-called Species and Subspecies.' <Science, N. S., XVI, pp. 383-386, Sept. 5, 1902.

Discussion of the subject, apropos of an article under the same title in a previous number of Science by Hubert Lyman Clark.

1905.

18. The Probable Origin of Certain Birds. <Science, N. S., XXII, No. 562, pp. 431434, Oct. 6, 1905.

Criticism of W. E. D. Scott's resort to the 'mutation theory' of deVries, in accounting for the origin of certain North American birds (Science, XXIII, pp. 272-282, Sept. 1, 1905).

19. The Evolution of Species through Climatic Conditions. <Science, N. S., XXII, No. 569, pp. 661-668, Nov. 24, 1905.

Apropos of a paper by D. S. Jordan on 'The Origin of Species through Isolation' (Science, XXII, pp. 545-552).

1906.

20. Heredity and Subspecies.<Science, N. S., XXIII, pp. 142-145, Jan. 26, 1906.

Discussed with reference to papers by Dr. D. S. Jordan on the same subject in previous issues of Science.

21. 'Barriers' and 'Bionomic Barriers'; or Isolation and Non-Isolation as Bionomic Factors. <Science, N. S., XXIII, pp. 310-312, Feb. 23, 1906.

In reference to papers on the same subject by Jordan and Evermann in previous issues of Science.

1907.

22. Mutations and the Geographic Distribution of nearly related Species in Plants and Animals.<Amer. Nat., XLI, pp. 653-655, Oct., 1907. 


\section{NOMENCLATURE. 1}

1883.

1. On Trinomial Nomenclature. <Zoölogist, 3d ser., VII, pp. 97-100, March, 1883.

1884 .

2. 'Are Trinomials Necessary?' <Auk, I, pp. 102-104, pp. 200-202, Jan. and April, 1884.

Replies to this question, raised by Montague Chamberlain (ibid., pp. 101-102, 198-200).

3. 'Can We not have a Simpler System of Nomenclature?' < Auk, I, pp. 297-300, July, 1884.

A letter of this title and editorial reply.

4. "A Lay View of 'Ornithophilologicalities.'” <Auk, I, pp. 300-304, July, 1884. An editorial reply to a letter of this title.

5. Zoölogical Nomenclature. <Auk, I, pp. 338-353, Oct., 1884.

On trinomial nomenclature, with particular reference to the views and practices of English ornithologists, apropos of a discussion of the "Expediency, or otherwise, of adopting Trinomial Nomenclature in Zoölogy," held in the Lecture Room of the Natural History Museum, London, July 2, 1884.

6. Stejneger on Trinomials in American Ornithology. $<A u k$, I, pp. 381-382, Oct., 1884.

Review of Dr. L. Stejneger's paper of this title (Proc. U. S. Nat. Mus., VII, 1884, pp. $70-81$, July 1,1884$)$, in which the history of trinomials is briefly given.

1887.

7. [The Antedating of papers and works on Natural History.] $<A u k$, IV, p. 176, April, 1887, and ibid., p. 270, July, 1887.

With special reference to the 'Proceedings' and other publications of the U. S. National Museum.

1890.

8. Waterhouse's 'Index Generum Avium.' <Auk, VII, pp. 71-73, Jan., 1890.

Review of F. H. Waterhouse's work of this title (8vo, London, 1889), with criticisms of omissions and defects, as the omission of all generic names founded before 1766, except Brisson's, and the giving of vernacular French names the status of proper generic terms.

9. Blanchard on the Nomenclature of Organized Beings. $<A u k$, VII, pp. $73-74$, Jan., 1890.

Review of Dr. Raphaël Blanchard's report 'De la Nomenclature des êtres organizés,' presented to the International Congress of Zoölogy (Reports to the Congress, pp. 87-157, July, 1889). Comment on some of the rulings in the report.

${ }^{1}$ With reference mainly to the general subject, and exclusive of special cases (Kerr, Oken, Pennant, retc.) and of incidental references in reviews and papers devoted chiefly to other subjects. 
1896.

10. Sclater on Rules for Naming Animals. $<A u k$, XIII, pp. 325-328, Oct., 1896.

Review of a paper by Dr. P. L. Sclater entitled " Remarks on the Divergencies between the 'Rules for Naming Animals' of the German Zoölogical Society and the Stricklandian Code of Nomenclature" (Proc. Zool. Soc. London, 1896, pp. 306-319), with critical comment on many of his positions on important points.

11. A Question of Nomenclature. <Auk, XIII, pp. 191-192, April, 1896.

In reply, by request, to an article of this title by H. C. Oberholser (ibid., pp. 190-191).

12. A reprehensible method of determining Priority of Publication. $<$ Science, N. S., IV, pp. 691-693, Nov. 16, 1896.

A criticism of resolutions on this subject adopted by the Zoölogical Section of the American Association for the Advancement of Science, August, 1895.

13. The Date of Publication. <Science, IV, pp. 838, 839, Dec. 4, 1896.

Further discussion of the subject, in reply to Professor Cope's defense of the American Association resolution. (See supra, No. 12).

\section{7.}

14. The Merton Rules. <Science, N. S., VI, pp. 16-19, July 2, 1897.

Comment on the rules compiled by Lord Walsingham and John Hartley Durant, "for regulating nomenclature with a view to secure a strict application of the Law of Priority in Entomological work."

1898.

15. A Defense of Canon XL of the A. O. U. Code.<Auk, XV, pp. 298-302, Oct., 1898 .

A reply to criticism by D. G. Elliot of Canon XL of the A. O. U. Code (ibid., pp. 294-298), in defense of taking names as originally spelled, and against the emendation of names.

16. 'Truth versus Error.' <Auk, XVI, Jan., 1899, pp. 46-51.

In reply to a second article, under this title, by D. G. Elliot (ibid., pp. 38-45), a rejoinder to the reply made to his first paper on the A. O. U. Canon XL. (See supra, No. 15.)

1902.

17. A Method of Fixing the type in Certain Genera. <Science, N. S., XVI, pp. 114, 115, July 18, 1902.

A rule proposed and signed by Allen, Baugs, Evermann, Gill, Howell, Jordan, C. H. Merriam, G. S. Miller, Jr., Mary Rathbun, Oldfield Thomas - a formal recognition of the principle of tautonymy.

1903.

18. Antedated Publications.<Science, N. S., XVIII, pp. 631-632, Nov. 13, 1903. Relates to publications of the Field Columbian Museum of Chicago.

1904.

19. Code of Botanical Nomenclature. <Auk, XXI, pp. 404-405, July, 1904.

Reviewed and compared with the A. O. U. Code and their general agreement noted (Bull. Torrey Botanical Club, XXXI, No. 5, May, 1904). 
1905.

20. A New Code of Nomenclature. <Science, N. S., XXI, pp. 428-433.

Criticism of 'A Provisional Code' by Doctors Jordan, Evermann and Gilbert, published in The Condor, VII, pp. 28-30, Jan., 1905.

\section{6.}

21. The 'Elimination' and 'First Species' Methods of Fixing the Types of Genera. $<$ Science, N. S., XXIV, pp. 773-779, Dec. 14, 1906.

In reply to a paper by Witmer Stone on the same subject (Science, XXIV, pp. 560-565, Nov. 2, 1906).

22. Subgenera and other Matters. <Auk, XXIII, pp. 122-125, Jan., 1906.

Relates to the non-recognition of Brissonian genera by Hartert in his 'Die Vogel der paläarktischen Fauna.

23. The Determination of Types of Genera - a Correction. <Science, N. S., XXIV, p. 858, Dec. 28, 1906.

Respecting the type of Vultur Linn.

1907.

24. The First Species Rule for determining Types of Genera - How it works in Ornithology.<Science, N. S., XXV, pp. 546-554, April 5, 1907.

Fourth paper in the Stone-Allen discussion of the 'First Species Question.'

25. Another Word on the Vultur Case. <Science, N. S., XXV, p. 827, May 24, 1907.

Further discussion of the first species rule.

26. Article 30 of the International Code of Zoölogical Nomenclature.<Science, N. S., XXVI, pp. 719-723, Nov. 22, 1907.

In hearty approval of the "new Article 30," and criticism of statements in a previous. article in Science by Witmer Stone.

1908.

27. Another Aspect of the Species Question. <Amer. Nat., XLII, pp. 592-600, Sept., 1908.

With reference to a report of the symposium held by the Botanical Society of America in Chicago, Jan. 1, 1908, and published in the Amer. Nat. for April, 1908, pp. 217-281.

1909.

28. Genera without Species. <Science, N. S., XXIX, No. 754, pp. 934-936, June 11, 1909.

With reference to previous papers on this subject by Prof. T. D. A. Cõckerell in the same volume of Science. The position is taken that such genera should each be treated on their merits, as against the proposed non-recognition of all such genera.

29. Genera without Species. <Science, N. S., XXX, No. 768, pp. 365-367, Sept. 17, 1909.

A continuation of the discussion (supra, No. 25), with special reference to an article by: Mr. A. N. Caudell. 
30. Recommendations regarding the treatment of Genera without Species, etc. <Science, N. S., XXX, No. 744, pp. 596-597, Oct. 29, 1909.

Covers two recommendations relating to genera without species, which are the outcome of the correspondence on this subject in Science, and directly with Prof. T. D. A. Cockerell.

1910.

31. The Determination of Genotypes in Zoölogy. Advance separate of a paper published in the Proceedings of the Seventh International Zoölogical Congress, Boston meeting, August 19-24, 1907 (8vo, pp. .7; separates received Jan. 24, 1910.)

32. Opinions rendered by the International Commission on Zoölogical Nomenclature.<Science, N. S., XXXII, No. 820, pp. 380-382, Sept. 10, 1910.

Summary of Opinions $\$ 1-25$, with comment.

1912.

33. Mathews's Notes on Nomenclature. <Auk, XXIX, pp. 133-135, Jan., 1912.

Rejoinder to Gregory M. Mathews's paper of this title (Auk, l. c., pp. 131-133), with special reference to the genus Colymbus Linné (1758) and Colymbus Brisson (1760), and to other Brissonian genera.

34. Suggested Amendments to the International Code of Zoölogical Nomenclature. Amendment Proposed by Dr. J. A. Allen. <Zool. Anz., XLI, pp. 38-45, Nov. $26,1912$.

Amendment to replace the 'Recommendations' following Art. 36, placing generic names on a basis similar to that of specific names under the Gratz (1910) amendment to Art. 35 .

\section{3.}

35. Propositions by J. A. Allen and T. D. A. Cockerell for Amendments to the International Code of Zoölogical Nomenclature.<Zool. Anz.; XLI, pp. 426427, March 11, 1913.

Species designated by only a vernacular name may, under certain conditions, be accepted as genotypes. 


\section{BIOGRAPHY. ${ }^{1}$}

1880.

1. Thomas Mayo Brewer.<Bull. Nutt. Ornith. Club, pp. 102-104, April, 1880; Proc. Amer. Acad. Arts and Sciences, VII, pp. 378-380, 1879-80; Proc. Boston Soc. Nat. Hist., XX, pp. 413-415.

1884 .

2. Wilson Flagg. $<A u k$, I, p. 306, July, 1884.

3. Henry George Vennor.<Auk, I, p. 306, July, 1884.

1885.

4. William Wood.<Auk, II, p. 391, Oct., 1885.

5. Harmon Albro Atkins. <Auk, II, p. 391, Oct., 1885.

1886.

6. Samuel Cabot.<Auk, III, p. 144, Jan., 1886.

7. Eugen von Boeck.<Auk, III, p. 496, Oct., 1886.

1887.

8. John Maynard Wheaton. <Auk, IV, p. 174, April, 1887.

9. Spencer Fullerton Baird. $<A u k$, IV, pp. 358-359, Oct., 1887.

1888.

10. Joseph Bassett Holder. <Auk, V, p. 220, April, 1888.

11. Charles Linden. $<A u k$, V, April, pp. 220-221, 1888

12. Philip Henry Gosse. <Auk, V, pp. 446-447, Oct., 1888.

1889.

13. Henry Stevenson. <Auk, VI, pp. 79-80, Jan., 1889.

14. August Friedrich Marschall. <Auk, VI, p. 80, Jan., 1889.

15. Nicolas Michaïlovitch Prjevalsky.<Auk, VI, pp. 80-81, Jan.: 1889.

1 The following biographical records relate almost exclusively to more or less prominent ornithologists, and were nearly all published in The Auk (1884-1911, inclusive) as editorial notices, without signature. They include not only American ornithologists but all the foreign ornithologists of note who died between the above-given dates. The references given here, it should be noted, include only a part of the formal biographies and obituaries published in The Auk during the period named, since the biographers of all deceased fellows of the A. O. U. are appointed by the President; also those of a number of the deceased Members and Associates have been prepared at the solicitation of the editor of The Auk, and not by him personally; such notices, of course, are not here included. 
16. Thure Kumlien. <Auk, VI, pp. 204-205, April, 1889.

17. S. Lowell Elliott. <Auk, VI, p. 206, April, 1889.

18. Richard Spaulding Wray.<Auk, VI, p. 206, April, 1889.

19. Jerome Henry Kidder. <Auk, VI, p. 282, July, 1889.

20. Eugen Ferdinand von Homeyer. $<A u k$, VI, p. 341, Oct., 1889.

1890.

21. Ladislas Taczanowski.<Auk, VII, p. 218, April, 1890.

22. John Henry Gurney.<Auk, VII, pp. 299-300, July, 1890.

23. William Kitchen Parker.<Auk, VII, pp. 411-412, Oct., 1890.

1891.

24. Ferdinand Krauss. <Auk, VIII, p. 120, Jan., 1891.

25. Henry Davis Minot.<Auk, VIII, p. 121, Jan., 1891.

26. Nathaniel Stickney Goss. <Auk, VIII, pp. 245-247, April, 1891.

27. John C. Cahoon. <Auk, VIII, p. 320, July, 1891.

28. John I. Northrop.<Auk, VIII, p. 400, Oct., 1891.

1892.

29. Hermann Burmeister. <Auk, IX, pp. 399-400, Oct., 1892.

30. August von Pelzeln. <Auk, IX, pp. 74-75, Jan., 1892.

31. John Amory Jeffries. <Auk, IX, pp. 311-312, July, 1892.

1893.

32. John Strong Newberry.<Auk, X, p. 95, Jan., 1893.

33. Philo R. Hoy. <Auk, X, pp. 95-96, Jan., 1893.

34. Jenness Richardson. <Auk, X, pp. 307-308, July, 1893.

35. Austin F. Park. <Auk, X, pp. 384-385, Oct., 1893.

36. Benjamin Franklin Goss. <Auk, X, p. 385, Oct., 1893.

37. Charles F. Adams. <Auk, X, pp. 385-386, Oct., 1893.

1894.

38. Charles Glover Allen. <Auk, XI, pp. 86-87, Jan., 1894.

39. Samuel Lockwood.<Auk, XI, pp. 189-190, April, 1894.

40. William Cushman Avery. <Auk, XI, p. 263, July, 1894.

41. Alexander Theodore von Middendorf. <Auk, XI, p. 264, July, 1894.

42. Leopold von Schrenck. <Auk, XI, p. 264, July, 1894.

1895.

43. John Whipple Potter Jenks. <Auk, XII, p. 94, Jan., 1895.

44. Edward Baldamus. <Auk, XII, p. 94, Jan., 1895.

45. George Newbold Lawrence. $<A u k$, XII, pp. 198-199, April, 1895.

46. Frederick H. Hoadley. <Auk, XII, p. 199, April, 1895. 
47. Edward Hargitt. <Auk, XII, p. 315, July, 1895.

48. John S. Cairns. <Auk, XII, p. 315, July, 1895.

49. Franklin Fairbanks. <Auk, XII, p. 315, July, 1895.

50. George Henry Ragsdale. <Auk, XII, p. 316, July, 1895.

1896.

51. Thomas Henry Huxley. <Auk, XIII, pp. 93-96, Jan., 1896.

52. Henry Seebohm. <Auk, XIII, pp. 96-97, Jan., 1896.

53. Henry T. Wharton. <Auk, XIII, p. 97, Jan., 1896.

54. Juan Gundlach. <Auk, XIII, p. 267, July, 1896.

55. Thomas Lyttleton (Lord Lilford). <Auk, XIII, pp. 348-349, Oct., 1896.

56. Eugene Carleton Thurber. $<A u k$, p. 349, Oct., 1896.

57. George Brown Goode. <Auk, XIII, p. 349, Oct., 1896.

1897.

58. Howard Gardner Nichols. <Auk, XIV, p. 115, Jan., 1897.

59. Charles Emil Bendire. <Auk, XIV, p. 253, April, 1897.

60. Heinrich Gätke. $<A u k$, XIV, p. 254, April, 1897.

61. Platt Marvin Thorne. $<A u k$, XIV, pp. 254-255, April, 1897.

62. Robert Lee Lawrence. <Auk, XIV, p. 342, July, 1897.

63. Edward Drinker Cope. <Auk, XIV, pp. 242-243, July, 1897.

64. Edward Newton. <Auk, XIV, p. 431, Oct., 1897.

1898.

65. George Baur. <Auk, XV, pp. 286-287, July, 1898.

66. Osbert Salvin. $<A u k$, XV, pp. 343-346, Oct., 1898.

1899.

67. Oliver Marcy.<Auk, XVI, p. 211, April, 1899.

68. Othniel Charles Marsh. <Auk, XVI, p. 211, April, 1899.

69. Joseph Wolf. <Auk, XVI, pp. 301-302, July, 1899.

70. John Cordeaux. <Auk, XVI, pp. 377-378, Oct., 1899.

1900.

71. Elliott Coues. <Auk, XVII, p. 91, Jan., 1900. (See also below Nos. 72 and 122.)

72. Elliott Coues. <Science, N. S., XI, pp. 161-163, Feb. 2, 1900.

73. Daniel Webster Prentiss. <Auk, XVII, pp. 91-92, Jan., 1900.

74. William W. Colburn. <Auk, XVII, p. 92, Jan., 1900.

75. George B. Sennett. <Auk, XVII, p. 193, April, 1900. (See also below, No. 79.)

76. William Edwin Brooks. <Auk, XVII, p. 194, April, 1900.

77. Alphonse Milne-Edwards. <Auk, XVII, pp. 320-321, Oct., 1900.

78. Edgar Leopold Layard.<Auk, XVII, pp. 321-322, Oct., 1900. 
1901.

79. In Memoriam: George B. Sennett.<Auk, XVIII, pp. 11-23, Jan., 1901, with portrait.

80. Gustav Hartlaub. <Auk, XVIII, p. 219, April, 1901.

81. George Augustus Boardman. <Auk, XVIII, pp. 219-220, April, 1901.

82. Édmond de Sélys Longschamps. <Auk, XVIII, pp. 292-293, July, 1901.

83. William MacGillivray. <Auk, XVIII, pp. 293-294, July, 1901.

Apropos of the unveiling of a memorial tablet to him at Marischal College, Aberdeen, Scotland, in 1900.

$\Rightarrow$ 84. Newton Dexter. <Auk, XVIII, p. 413, Oct., 1901.

1902.

85. John Anderson. <Auk, XIX, p. 118, Jan., 1902.

86. Armand David.<Auk, XIX, p. 118, Jan., 1902.

87. Lionel William Wigglesworth. <Auk, XIX, p. 119, Jan., 1902.

88. James Graham Cooper. <Auk, XIX, pp. 421-422, Oct., 1902.

1903.

89. Emil Holub. <Auk, XX, p. 92, Jan., 1903.

90. Ludwig Kumlien. $<A u k$, XX, pp. 93-94, Jan., 1903.

91. Perry O. Simons. $<A u k$, XX, pp. 94-96, Jan., 1903.

92. John James Audubon. $<A u k$, XX, pp. 85-86, Jan., 1903.

Review of John Burrough's biography of Audubon (12mo, Boston, 1903).

93. Thomas McIlwraith.<Auk, XX, p. 242, April, 1903

94. John Nathaniel Clark. $<A u k$, XX, pp. 242-243, April, 1903.

95. Edward Stanley Waters. <Auk, XX, p. 243, April, 1903.

96. Mrs. E. S. Mogridge. <Auk, XX, pp. 327-328, July, 1903.

97. Gustav Ferdinand von Radde. <Auk, XX, pp. 458-459, Oct., 1903.

1904.

98. Lyman S. Foster. <Auk, XXI, p. 312, April, 1904.

99. John Fannin. $<A u k$, XXI, p. 510, Oct., 1904.

100. James Mortimer Southwick.<Auk, XXI, p. 511, Oct., 1904.

1905.

101. Adolph Boucard. <Auk, XXII, p. 333, July, 1905.

1906.

102. Jean Louis Cabanis. <Auk, XXIII, pp. 247-485, April, 1906.

103. Paul Leverkuhn. $<A u k$, XXIII, p. 247, April, 1906.

104. Émile Oustalet. <Auk, XXIII, pp. 355-356, July, 1906.

105. George F. Breninger. <Auk, XXIII, p. 356, July, 1906.

106. LaRue Klingle Holmes. < Auk, XXIII, p. 356, July, 1906. 
107. Joseph H. Batty. <Auk, XXIII, pp. 356-357, July, 1906.

108. Frank J. Thompson. <Auk, XXIII, pp. 357-358, July, 1906.

109. Henry Baker Tristram. <Auk, XXIII, p. 484, Oct., 1906.

110. Victor Fatio <Auk, XXIII, pp. 484-485, Oct., 1906.

\section{7.}

111. William Thomas Blanford. $<A u k$, XXIV, p. 118, Jan., 1907.

112. Walter Lawry Buller. <Auk, XXIV, p. 119, Jan., 1907.

113. August Koch. $<A u k$, XXIV, pp. 238-239, April, 1907

114. Alfred Newton. $<A u k$, XXIV, pp. 365-366, July, 1907.

115. Carl von Linné (Linnæus as a Zoölogist). <Science, N. S., XXV, pp. 953-961, June 21, 1907. Also Ann. New York Acad. Sci., XVIII, pp. 9-19, pll. ii, 1908 , portraits.

An address given at the celebration of the Bicentenary of the birth of Linnæus, in New York, May 23, 1907.

1908.

116. Howard Saunders. <Auk, XXV, pp. 103-104, Jan., 1908.

117. Rudolph Blasius. <Auk, XXV, p. 248, April, 1908.

118. Leslie Alexander Lee. $<A u k$, XXV, p. 340, July, 1908.

119. Edward Augustus Samuels. $<A u k$, XXV, p. 341, July, 1908.

120. J. V. Barboza du Bocage. $<A u k$, XXV, p. 498, Oct., 1908.

121. Francis Huntington Snow. <Auk, XXV, p. 498, Oct., 1908.

1909.

122. Elliott Coues. (Biographical Memoir.)<National Acad. Sci., Biogr. Mem., VII, pp. 397-446, June, 1909.

With portrait, and lists of his principal works and papers (pp. 426-446).

123. Charles K. Worthen. <Auk, XXVI, p. 332, July, 1909, ibid., XXVII, p. 112.

124. William H. Brownson. <Auk, XXVI, p. 453, Oct., 1909.

1910.

125. Richard Bowdler Sharpe.<Auk, XXVII, pp. 124-129, Jan., 1910, with portrait.

126. John Farwell Ferry.<Auk, XXVII, pp. 240-241, April, 1910.

127. Henry Hillyer Giglioli. <Auk, XXVII, pp. 484-485, Oct., 1910.

128. William Earl Dodge Scott. <Auk, XXVII, pp. 486-488, Oct., 1910.

1911.

129. Charles Otis Whitman. <Auk, XXVIII, p. 149, Jan., 1911.

130. Manly Hardy.<Auk, XXVIII, pp. 149-150, Jan., 1911; ibid., p. 291, July, 1911.

131. George Ernest Shelley. <Auk, XXVIII, pp. 387-388, July, 1911.

132. Carl Parrot. <Auk, XXVIII, p. 388, July, 1911.

133. Adolf Bernhard Meyer. <Auk, XXVIII, p. 519, Oct., 1911.

1916.

134. Daniel Giraud Elliot. <Science, N. S., No. 1101, pp. 159-162, Feb. 4, 1916. 


\section{MISCELLANEOUS.}

$1865-1884$.

1. Curatorial Reports on Mammals and Birds. $<$ Ann. Reports of the Trustees of the Mus. Comp. Zoöl., 1865-1884.

1866.

2. Notice of a Foray of a Colony of Formica sanguinea Latr. upon a Colony of a black species of Formica, for the purpose of making slaves of the latter. < Proc. Essex Inst., V, pp. 14-16, April, 1866.

1870.

3. The Flora of the Prairies. <Amer. Nat., IV, pp. 577-585, Dec., 1870.

A running account of the more striking features, with particular mention of many species.

4. Notes on the Geological Character of the Country between Chique-Chique, on the Rio de São Francisco, and Bahia, Brazil. < Hartt's Geology and Physical Geography of Brazil, pp. 309-319. (8vo, Boston, 1870.)

Also inedited geological and zoölogical notes, passim.

5. Our Weeds. <Massachusetts Ploughman, July 23-Oct. 8, 1870.

A series of six articles, published as follows:

Number 1, Introductory, July 23, 1870; No. II, The Crowfoots (Ranunculacaæ) and the Poppy Family (Papaveraceæ), July 30, 1870; No. III, The Cruciferæ, Cistaceæ or Rock Roses, and the Hypericaceæ (St. Johnswort Family), Aug. 13, 1870; No. IV, The Pink Family (Caryophyllaceæ), the Purselanes (Portulacaceæ), the Mallow Family (Malvaceæ), Aug. 27, 1870; No. V, The Pulse Family (Leguminosæ), Sept. 24, 1870; No. VI, The Rose Family (Rosaceæ), Evening Primrose Family (Onagraceæ), Orpine or Stone Crop Family (Crasulaceæ), Oct. 8, 1870.

1874.

6. Metamorphism produced by the burning of Lignite Beds in Dakota and Montana Territories. <Proc. Boston Soc. Nat. Hist., XVI, 1873-1874, pp. 246262, May, 1874.

7. Notes on the Natural History of Montana and Dakota.<Proc. Boston Soc. Nat. Hist., XVII, 1874-1875, pp. 33-91, Nov., 1874.

Report on the Plants, pp. 70-86 (pp. 40-56 of the separate issue). An annotated list of 224 species, based mainly on identifications by Dr. George Vasey, Botanist of the Department of Agriculture, to whom the collection of plants was referred for determination. 
$1874-75$.

8. Boston Society of Natural History. Reports of Meetings. <Boston Transcript (newspaper), Nov. 15, 1874, to June 8, 1875.

Meeting of Oct. 7, 1874. Ibid., Nov. 15, 1874.

Meeting of Oct. 21, 1874. Ibid., Nov. 21, 1874.

Meeting of Nov. 4, 1874. Ibid., Nov. 27, 1874.

Meeting of Nov. 18, 1874. Ibid., Dec. 2, 1874.

Meeting of Dec. 2, 1874. Ibid., Dec. 17, 1874.

Meeting of Dec. 16, 1874. Ibid., Dec. 30, 1874 .

Meeting of Jan. 6, 1875. Ibid., Jan. 25, 1875.

Meeting of Jan. 20, 1875. Ibid., Feb. 1, 1875.

Meeting of Feb. 3, 1875. Ibid., Feb. -, 1875.

Meeting of Feb. 17, 1875. Ibid., March 1, 1875.

Meeting of March 3, 1875. Ibid., March -, 1875.

Meeting of March 17, 1875. Ibid., April -, 1875.

Meeting of April 7, 1875. Ibid., April -, 1875.

Meeting of April 21, 1875. Ibid., May -, 1875.

Meeting of May 5, 1875. Ibid., May -, 1875.

Meeting of May 19, 1875. Ibid., June 8, 1875.

These popular reports of the meetings were furnished to the press by the author as a part of his duties as Acting Secretary of the Society

1876.

9. The Little Missouri "Bad Lands".<Amer. Nat., X, pp. 207-216, April, 1876. With reference to metamorphism due to the burning out of heavy beds of lignite.

10. Nuttall Ornithological Club. <Bull. Nutt. Orn. Club, I, pp. 29-32, July, 1876.

Historical sketch of the Club (1873-1876), giving an account of its origin and organization and a list of its publications prior to the establishment of its Bulletin in 1876.

1884.

11. Italics for Scientific Names. <Science, III, No. 51, p. 87, Jan. 25, 1884.

Refers to the advantage of using italic type for the technical names of genera and species, as an aid in finding the information sought.

1885.

12. Department of Birds and Mammals. <Ann. Rep. Trustees Amer. Mus. Nat. Hist. for the year 1885-6, pp. 9-12, March, 1886.

Report on the extent and condition of the collections; need of 'study' or research material urged; also of increased exhibition space.

1886.

13. [Establishment of the Division of Economic Ornithology and Mammalogy under the United States Department of Agriculture.] $<A u k$, I, p. 416, July, 1886 , 
1887.

14. Third Annual Report of the Curator of the Department of Mammalogy and Ornithology, 8vo, pp. 1-10.

A brochure privately printed by order of the President. Reprinted in part in Ann. Report Trustees Amer. Mus. Nat. Hist. for the year 1887-1888, pp. 12-16.

To a report on the accessions and activities of the year 1887 is added: 'Wants and Recommendations,' and letters to the President of date Nov. 7, 1887 and Jan. 21, 1888, in advocacy, respectively, of the purchase of an important collection of North American birds, and of sending expeditions to the West to secure specimens of bison, elk, caribou, pronghorn antelope, mountain sheep, and other forms of rapidly disappearing large North American mammals.

1888.

15. The Museum of Natural History. An Appeal for Aid in Carrying on its Work. $<$ New York Evening Post, Feb. 28, 1888.

Of the $\$ 64,000$ expended in 1877 , all but $\$ 15,000$ was furnished by the Trustees. The accessions received and the work accomplished by the Department of Mammalogy and Ornithology is recounted, and a plea made for financial assistance on the part of the public through aid by membership, etc., in return for free access to the exhibition halls of the Museum.

16. The Museum of Natural History. <New York Tribune, Feb. 24, 1888.

Published as editorial, about 500 words.

1890.

17. Zoe, A Biological Journal. <Auk, VII, p. 300, July, 1890.

Announcing the founding, objects and character of this excellent journal of which four volumes (1890-1893) were published.

1893.

18. The Natural History Museum of New York City. <New York Evening Post, Feb. 28, 1893.

Its scientific work as set forth in the Bulletin of the Museum.

19. Letter on alleged skinning of Kids and Birds while alive, to improve the quality of their Skins or Plumage for Commercial Purposes. <Our Animal Friends, XX, p. 268, No. 12, Aug., 1893.

20. Letter in reply to the question "How does the Study of Nature Pay?" $<$ The Hesperian (newspaper), Gainesville, Texas, March 31, 1893.

Letter to Geo. H. Ragsdale.

Bibliography: Summary of Titles.

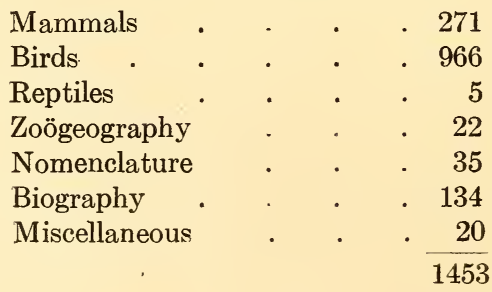




\title{
IX. EDITORIAL WORK.
}

\author{
$1874-1875$.
}

The Proceedings of the Boston Society of Natural History, Vol. XVIII, for 1874-1875, and part of Vol. IX of the American Naturalist, in the temporary absence of their respective editors.

\section{$1876-1883$.}

Bulletin of the Nuttall Ornithological Club, Vols. I-VIII, Cambridge, Mass. Published by the Club, 8vo, 1876-1883.

The first number of this publication was issued in April, 1876, under the editorship of Mr. Charles J. Maynard, and under the title Quarterly Bulletin of the Nuttall Ornithological Club, Cambridge, Mass. With the second number (July, 1876) the title was changed to Bulletin of the Nuttall Ornithological Club: A Quarterly Journal of Ornithology, with, on the fourth page of the cover, a 'Prospectus,' which statcs: "The need in this country of a periodical exclusively devoted to Ornithology has been long apparent.....Each number will consist of not less than twenty-four pages, to be increased as soon as the receipts from subscriptions shall warrant the additional expense. Two more numbers will be issued during the present year, in order that the second volume may begin with January, 1877 ....Professor Baird and Dr. Coues have kindly consented to act as Associate Editors. Its chief editorial management will be under the direction of Mr. J. A. Allen of the Museum of Comparative Zoölogy, Cambridge, Mass...." No. 4 was issued November, 1876. Volume I consists of pp. i-iv, 1-100, with a colored plate, engraved on steel.

The volumes, under the same editorial staff, steadily increased in size to Vol. VII, 1882 (pp. i-vi, 1-275). Number 4 of Volume VIII (October, 1883) contained this "Important Notice: The First Series of the Bulletin of the Nuttall Ornithological Club closes with the present volume. A Second Series, with change of name, will begin with January, 1884, under the auspices of the American Ornithologists' Union, and under the Editorial Management of Mr. J. A. Allen, assisted by a Staff of Associate Editors...."

The Associate Editors of the eight volumes of the Bulletin were Spencer F. Baird and Elliott Coues.

$$
1884-1911 .
$$

The Auk: A Quarterly Journal of Ornithology, Vols. I-XXVIII, 1884-1911, and No. 1 of Vol. XXIX (Jan., 1912).

Title-page of Vol. I:

Old Series, $\}$

Vol. IX

\author{
Continuation of the \\ Bulletin of the Nuttall Ornithological Club

$$
1-1
$$

The Auk | A Quarterly Journal of Ornithology | - Editor, | J. A. Allen | Associate Editors, | Elliott Coues, Robert Ridgway, William Brewster, | and Montague Chamberlain. [Cut of Great Auk, $4 \frac{1}{2} \times 5$ in. | Volume I | Published for the American Ornithologists' Union | Boston, Mass. | Estes and Lauriat | 1884.

The second page of the cover of the first number carries the following: "'The Auk, published as the Organ of the American Ornithologists' Union, will be conducted as a Magazine of General Ornithology. In general character it will differ little from the late 'Bulletin of the Nuttall Ornithological Club,' of which it forms virtually a Second Series. Each number will contain about one hundred pages, and the illustrations will occasionally include colored plates."

The first volume of 'The Auk' consists of pp. i-vii, 1-419, and 1 colorcd plate. This is about the average size for the first 19 volumes, the last 7 averaging 500 pages, in each case 
exclusive of front-matter (contents and membership lists), which runs, in different volumes, from 8 to nearly 40 pages.

In The Auk, as in its predecessor, the Nuttall Bulletin, the department of 'Recent Literature' was intended to include notices (1) of all ornithological works and papers by American authors; (2) all papers, wherever published, relating especially to North American birds; (3) all of the more important monographs and works treating of special groups of birds or of birds in general. In 1880 was begun a series of papers entitle 'Minor Ornithological Papers,' giving the title, place of publication, and short notices or abstracts of the minor papers relating to North American birds, not otherwise noticed under 'Recent Literature,' subject however to certain stated restrictions as to their content. The record began "with the close of that given by Dr. Coues in his 'List of Faunal Publications relating to North American Ornithology' published in his 'Birds of the Colorado Valley,' or about July, 1878," and closed in 1894, after having been a feature of 'The Auk' for fourteen years. The last title of the series was No. 2697. Nos. 1-1199 were by the editor, the others (Nos. 1200-2697) by C. F. Batchelder, who from 1888 to 1893 (both inclusive) was Associate Editor of The Auk and greatly lightened for this period the duties of the senior editor.

The Associate Editors of The Auk for the first four volumes (1884-1887) were Elliott Coues, Robert Ridgway, William Brewster, and Montague Chamberlain. They were succeeded by Charles F. Batchelder (1888-1893) and Frank M. Chapman (1894-1915).

"Beginning with the initial volume of the Bulletin of the Nuttall Ornithological Club, and continuing to the present year, Dr. Allen has, without intermission guided the course of this journal and its successor THE AuK; and the series of thirty-six volumes stands as a perpetual monument to his ability, and his painstaking devotion to the cause of ornithology and the interests of the American Ornithologists' Union. There have been few continuous editorships of equal length in the history of scientific periodicals."- Editorial statement by Wituer Stone, Auk, XXIX, p. 136, Jan., 1912.

\section{6.}

The Code of Nomenclature | and | Check-List | of | North American Birds | adopted by the American Ornithologists' Union | being the Report of the Committee of the | Union on Classification and | Nomenclature - Zoölogical Nomenclature is a means, not an end, of Zoölogical Science $|-|$ New York | American Ornithologists' Union | 1886. 8vo, pp. i-viii, 1-392.

Contains The Code of Nomenclature (pp. 1-69) and The Check-List of North American Birds, according to the Canons of Nomenclature of the American Ornithologists' Union (pp. 71-392).

$1886-1916$.

Bulletin of the American Museum of Natural History, Vols. I, No. 6, to XXXV, excluding Vols. XV, XVII and XVIII, devoted to anthropology. (8vo; New York.)

\section{$1889-1895$.}

Supplement to the Code of Nomenclature and Check-List of North American Birds, adopted by the American Ornithologists' Union. Prepared by a Committee of the Union. 8vo, pp. 23. New York, American Ornithologists' Union, 1889.

Check-List | of | North American Birds | prepared by a Committee | of the | American Ornithologists' Union | Second and revised edition | - | Zoölogical Nomenclature is a means, not an end, of Zoölogical Science $|-|$. New York | American Ornithologists' Union | 1895. 8vo, pp. i-xi, 1-372.

Supplements Nos. 2 to 15 to the Check-List were published at intervals in The Auk from 1890-1909, and also issued separately in an edition of 100 copies. 
$1893-1916$.

Memoirs of the American Museum of Natural History. Vols. I and IX (Zoölogy and Palæontology), and general supervision of Vols. II, III, IV, and VI (Anthropology). Also, New Series, Vol. I, 1913-1916.

1908

The | Code of Nomenclature | adopted by the | American Ornithologists' Union | Zoölogical Nomenclature is a means, not an end, of Zoölogical Science $\mid-1$ Revised edition | New York | American Ornithologists' Union| July, 1908. 8vo, pp. i-lxxxv.

1910.

Check-List | of | North American Birds | prepared by a Committee | of the | American Ornithologists' Union|Third Edition (Revised) $|-|$ Zoölogical Nomenclature is a means, not an end, of Zoölogical Science $|-|$ New York $\mid$ American Ornithologists' Union | 1910. 8vo, pp. 1-430, 2 maps of North America, one of them colored to show faunal areas. 



SMITHSONIAN INSTITUTION LIBRARIES

|||||||||||||||||||||||||||||||||||||||||||||||||||||||||||||||||||||||||||||||||||||||||||

crls Z8028 A427

Autobiographical notes and a bibliograph 